

\title{
medieval worlds
}

comparative \& interdisciplinary studies

\author{
Volume 2018.7
}

\section{Verging on the Polemical: Exploring the Boundaries of Medieval Religious Polemic across Genres and Research Cultures}

Guest Editor: Sita Steckel

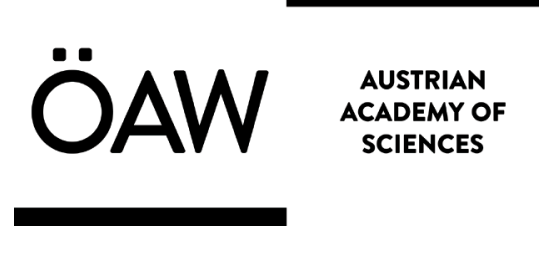




\section{medieval worlds comparative \& interdisciplinary studies}

All rights reserved

ISSN 2412-3196 Online Edition

Media Owner: Institute for Medieval Research

Copyright @ 2018 by Austrian Academy of Sciences, Vienna

Cover design, layout: Anneke Gerloff

Austrian Academy of Sciences Press

Dr. Ignaz Seipel Platz 2, 1010 Vienna, Austria

Tel. +43-1-515 81/DW 3402-3406

Fax +43-1-515 81/DW 3400

hw.oeaw.ac.at, verlag.oeaw.ac.at 


\section{Editors}

Walter Pohl, Austrian Academy of Sciences/University of Vienna

Andre Gingrich, Austrian Academy of Sciences/University of Vienna

\section{Editorial Board}

Maximilian Diesenberger, Austrian Academy of Sciences

Bert Fragner, Austrian Academy of Sciences

Christian Gastgeber, Austrian Academy of Sciences

Johann Heiß, Austrian Academy of Sciences

Claudia Rapp, Austrian Academy of Sciences/University of Vienna

Irene van Renswoude, Huygens Institute for the History of the Netherlands/

Royal Netherlands Academy of Arts and Sciences

Pavlína Rychterová, Austrian Academy of Sciences

Veronika Wieser, Austrian Academy of Sciences

\section{International Advisory Board}

Glenn Bowman , University of Kent

Sabrina Corbellini, University of Groningen

Mayke de Jong, Utrecht University

Nicola di Cosmo, Institute for Advanced Study, Princeton

Stefan Esders, Free University of Berlin

Patrick Geary, Institute for Advanced Study, Princeton

John Haldon, Princeton University

William C. Jordan, Princeton University

Osamu Kano, Nagoya University

Hugh Kennedy, SOAS, University of London

Gábor Klaniczay, Central European University

Lars Boje Mortensen, University of Southern Denmark

Elisabeth Lambourn, De Montfort University Leicester

Eduardo Manzano, Centro de Ciencias Humanas y Sociales (CSIC)

Helmut Reimitz, Princeton University

Marina Rustow, John Hopkins University

Dittmar Schorkowitz, Max Planck Institute for Social Anthropology

Teresa Shawcross, Princeton University

Naomi Standen, University of Birmingham

John Tolan, University of Nantes

Przemysław Urbańczyk, Polish Academy of Sciences

Dan Varisco, Qatar University

Luo Xin, Peking University

Journal Management

Celine Wawruschka

Homepage

www.medievalworlds.net 


\section{Table of Contents}

Verging on the Polemical

Sita Steckel

Anti-Jewish Polemics in Business Documents from Late Medieval Austria

Birgit Wiedl

61

Good and Bad Friars

Melanie Brunner

80

Obediencia, reformatio and veritas

Bénédicte Sère

Polemics Investigated in a Late Fifteenth-Century Fastnachtspiel

Claudia Daiber

The Text as Heretic

Justine Trombley

Transfers of Anti-Waldensian Material from a Polemical Treatise to a Didactic Text Reima Välimäki

Magistra magistrorum: Hildegard of Bingen as a Polemicist Andra Alexiu 


\title{
Verging on the polemical. Towards an interdisciplinary approach to medieval religious polemic
}

\author{
Sita Steckel*
}

The present article attempts to take stock of the different definitions and connotations of the concept of religious "polemic « in order to encourage a more interdisciplinary debate on this topic. It argues that the interdisciplinary research fields engaging with religious polemics could generate important historical perspectives on current conflict cultures, and appear to be on the verge of an expansion of the horizon towards the global, connecting an extant, highly active research field on religious encounter in the Euro-Mediterranean area to the study of Asia and Africa. To be able to realize an integrative perspective and to write a comparative and entangled history of religious polemics, it seems necessary to reflect on the differences and gaps marking the overlapping research fields. The article therefore offers a brief historiographical sketch concerning the concept of "polemics «, and then offers a preliminary list of constituents or dimensions of the polemical which have been highlighted in the different research fields. In a concluding section, case studies from the accompanying contributions in this volume furnish examples on possible further perspectives, with an emphasis on non-traditional approaches cutting across established research fields.

Keywords: Religious polemics, inter-religious contact, intra-religious conflicts, medieval Judaism, medieval Latin Christianity, medieval Islam, history of Medieval Studies.

\section{Introduction: The problems and potentials of an interdisciplinary approach to religious polemics}

The study of religious polemics remains a highly active subfield of the study of religion, especially in research concerning the medieval Euro-Mediterranean area. Given the prominence of hate speech and religion-based stereotyping today, the relevance and urgency of this topic hardly need to be stressed. Engaging with religious and cultural conflicts and their polemical fallout in a long-term perspective provides us with a unique opportunity to reflect on the dynamics of public debate evolving in different historical societies, including our own present. Within this horizon - which implies a focus on the cultures of debate and conflict visible in polemical exchanges, rather than on their specific religious content - it seems especially

* Correspondence details: Junior Professor Dr. phil. Sita Steckel, Historisches Seminar, Westfälische WilhelmsUniversität Münster, Domplatz 20-22, D-48145 Münster, Deutschland. Email: Sita.steckel@uni-muenster.de. The present thematic section includes papers which originated in sessions of IMC Leeds 2016 and 2017, and the author would like to thank all participants and moderators of the sessions, including Stephanie Kluge. A brief discussion of the articles is offered in the concluding section of the present text. 
important to strengthen emerging interdisciplinary perspectives. On the one hand, this can help to intensify the exchange between pre-modernists and modernists engaging with current political cultures. ${ }^{1}$ On the other, it contributes to an emerging global perspective on the connections and entanglements of religious polemics in different areas, such as Europe and the Mediterranean, the Near and Middle East, Africa and Asia. ${ }^{2}$

Given these imperatives, it is highly welcome that several recent publications have provided new interdisciplinary impulses to the study of religious polemic, juxtaposing historical cases from different contexts and rethinking the theoretical and methodological underpinnings of the field. ${ }^{3}$ But we nevertheless face some conceptual issues, especially in the understanding of the varied and complex phenomenon of religious polemics itself. As Hermann Stauffer noted in 2003, we must operate without a medieval terminology of the "polemical«, as the term only came into use from the seventeenth century onwards, and today acts as an umbrella for several different pre-modern traditions. Instead of a clear modern definition, we also deal with several, partially overlapping ones. ${ }^{4}$ As will be discussed in detail below, "polemic « may be understood very broadly to describe any form of controversy. It may be understood more specifically to denote illegitimate, transgressive argumentation, or it may simply be a shorthand for forms of disparagement and cultural devaluation. ${ }^{5}$ This polyvalence of the term "polemics" appears especially problematic for interdisciplinary research.

As even a superficial analysis shows, the heterogeneous research field of pre-modern religious polemics is indeed characterized by many faultlines. Primarily, these mirror the traditional geographical and chronological subdivisions of academic research, which separate Europe from Asia and other regions, and (at least within European historical studies) the medieval from the (early) modern. In a marked process of interdisciplinary convergence in the last three decades, a highly integrated research field centred on religious encounters between Judaism, Christianity, and Islam in the Euro-Mediterranean area has developed. As only a few regions actually hosted prolonged three-way religious exchange, however (and as academic departments usually favour the study of one religion in its wider contexts), many of the relevant studies have actually devoted themselves to investigating dyadic relationships

1 See, e.g., the recently established Sonderforschungsbereich 1285 "Invectivity. Constellations and Dynamics of Disparagement«, Technische Universität Dresden, at www.tu-dresden.de/gsw/sfb1285?set_language=en (accessed 21.01.2018)

2 See, e.g., the important remarks by Palumbo, From Constantine the Great to Emperor Wu. A connected history of polemics also forms part of the ongoing ERC research project »Jews and Christians in the East: Strategies of Interaction between the Mediterranean and the Indian Ocean«, led by Alexandra Cuffel, Bochum, see www.jewseast. org (accessed 21.01.2018).

3 See especially Sère, Régimes de polémicité; Suerbaum et al., Polemics; Azoulay and Boucheron, Le mot qui tue; Bouhaik-Gironès et. al., Usages et strategies polémiques. An important starting point for the study of religious polemics is still offered by Hettema and Van der Kooij, Religious Polemics in Context.

4 Stauffer, Polemik, 1403.

5 See section 2 below. 
- primarily, those of Christians and Jews, ${ }^{6}$ Christians and Muslims, ${ }^{7}$ and Muslims and Jews. ${ }^{8}$ A handful of other historical confrontations also generated research traditions on medieval religious polemic, for example the exchanges between the Byzantine Greek Orthodox Church and other churches, dissenters, and religions. ${ }^{9}$ More recently, the mainstream of Medieval Studies has begun to acknowledge the complex exchanges between Eastern Christianities, Islam, Zoroastrianism, and other religions, bridging the distance from Byzantium across Syria towards India and China, or from the Middle East towards Africa. ${ }^{10} \mathrm{~A}$ similar picture presents itself for Asian religions, only rarely studied in connection with Medieval Studies but beginning to come into the ambit of comparative and connected history-based approaches. In this field, research often revolves around particular religions such as Buddhism and Taoism and their relationships to other larger traditions. ${ }^{11}$ More or less in a category of its own, research on medieval heresies and heretical movements or related boundary concepts has a long and distinguished tradition, ${ }^{12}$ not only in the study of Christianity, ${ }^{13}$ but also of Judaism ${ }^{14}$

6 See, e.g., (with references to further literature) Abulafia, Christian-Jewish Relations; Baumgarten and Galinski, Jews and Christians in Thirteenth-Century France; Baumgarten et. al., Entangled Histories; Berger, Persecution, Polemic, and Dialogue; Blumenkranz, Auteurs Chrétiens latins; Bonfil et. al., Jews in Byzantium; Carlebach and Schacter, New Perspectives on Jewish-Christian Relations; Chazan, From Anti-Judaism to Anti-Semitism; Cluse, Europas Juden im Mittelalter; Cohen, Living Letters of the Law; Dahan, Christian Polemic; Lasker, Jewish Philosophical Polemics; Trautner-Kromann, Shield and Sword; Yuval, Zwei Völker in deinem Leib.

7 See, e.g., (with references to further literature) Bechmann et. al., Islam im kulturellen Gedächtnis; Burman, Religious Polemic; Conklin Akbari, Idols in the East; Di Cesare, Pseudo-Historical Image of the Prophet; Samir and Nielsen, Christian Arabic Apologetics; Tolan, Saracens; Tolan, Sons of Ishmael; Tolan et. al., Europe and the Islamic World; König, Arabic-Islamic Views; and cf. the first five volumes of Thomas et. al., Christian-Muslim Relations; Tischler and Fidora, Christlicher Norden, Muslimischer Süden.

8 See, e.g., (with references to further literature) Conermann, Muslim-Jewish Relations; Cohen, Middle Ages; Friedmann, Tolerance and Coercion in Islam; Lazarus-Yafeh, Intertwined Worlds; Frank, Jews of Medieval Islam. For a study of cross-cultural views of Islam, see, e.g., Hoyland, Muslims and Others.

9 See, e.g., Beck, Kirche und theologische Literatur; Bonfil et. al., Jews in Byzantium; Bucossi, Dialogues and Anthologies of the Sacred Arsenal; Kolbaba, Byzantine Lists; Rigo and Ermilov, Heresy and Orthodoxy in Byzantium.

10 See, e.g., (with references to further literature) Weltecke, Space, Entanglement and Decentralization; Marx et. al., Östliches Christentum; Pogossian, Conceptual Frontier; Ruani, Controverses religieuses en syriaque; Shaked, Dualism in Transformation; Sims-Williams, Some Reflections on Zoroastrianism; Galík and Slobodník, Eastern Christianity, Judaism and Islam; Malek and Hofrichter, Jingjiao; Tang and Winkler, From the Oxus River. On medieval religious encounter in Africa, see e.g. Dege-Müller, Between Heretics and Jews; or the forthcoming dissertation Verena Krebs, Windows onto the World: Culture Contact and Western Christian Art in Ethiopia, 1402-1543.

11 See (with further references to the literature) Palumbo, From Constantine the Great to Emperor Wu; Zürcher, Buddhist Conquest of China, 254-320; Kohn, Laughing at the Tao; Gorisse, Taste of the Mango; Liu and Shek, Heterodoxy in Late Imperial China; Baskind, Christian-Buddhist Polemics; Höckelmann, Antiklerikalismus und Exklusionsrhetorik; Hureau, Apparition de thèmes anticléricaux.

12 In a transculturally comparative perspective, see Ames, Medieval Heresies; Henderson, Construction of Orthodoxy and Heresy.

13 See, e.g., (with references to the further literature) Iricinschi and Zellentin, Heresy and Identity; Sackville, Heresy and Heretics; Simpson and Roach (eds.), Heresy and the Making of European Culture; Lambert, Medieval Heresy; Laursen et. al., Heresy in Transition; Lourdaux and Verhelst, Concept of Heresy; Van Dussen and Soukup (eds.), Religious Controversy in Europe.

14 See, e.g., Rustow, Heresy and the Politics of Community; Rustow, Karaites Real and Imagined; Diamond, Converts, Heretics and Lepers. 
and Islam. ${ }^{15}$ Because of practical and linguistic barriers, however, many of these fields have developed their own approaches to polemics, providing new definitions and typologies geared towards the study of particular traditions, such as Christian-Jewish polemical exchange. ${ }^{16}$

A closer look also shows other faultlines on the research field. As studies investigating religious polemics were often primarily interested in the phenomenon of religious encounter, sources which appeared to document such encounter best - inter-religious disputations, dialogues and legal sources - have drawn most interest. ${ }^{17}$ This has produced many important scholarly editions and studies of the prime textual witnesses to religious encounters over the last decades. As the medieval centuries had no explicit concept of "polemic", and therefore no textual genres clearly defined as such, however, instances of discourse we call polemical were in many cases spread much further into different genres and discourses than just the classical formats of dialogues and disputations. But texts only containing brief polemical passages, or genres such as, for example, satires about religious elites, have often remained disconnected from other relevant research.

An even more important faultline concerns the divisions between inter-faith or inter-religious polemic and intra-religious polemic (as well as extra-religious polemic ${ }^{18}$ ). As the medieval centuries had different, surprisingly dynamic concepts of the phenomena we call "religion ${ }_{19}^{19}$ the modern division between inter-religious and intra-religious polemic - and instinctual focus on encounter classed as »inter-religious « according to modern views - appears quite problematic. ${ }^{20}$ We know that historical taxonomies of religion, such as the ones current in medieval Christianity, typically show no stable separations between groups we understand as distinct religions (like Judaism or Islam), as intra-religious movements (heresies or religious orders) or finally as other practices involving the sacred (such as sorcery). ${ }^{21}$ Pioneers like Max Weber or the German medieval historian Herbert Grundmann therefore recommended a connected perspective on different religious experts. ${ }^{22}$ But except for some recent studies, such as Hans-Werner Goetz's study of the early and high medieval Christian

15 Adang et. al., Accusations of Unbelief in Medieval Islam; Fierro, Orthodoxy and Heresy in Islam; Ess, Der Eine und das Andere; on the problems of a cross-cultural concept of heresy, see, e.g., Wilson, The Failure of Nomenclature.

16 See, e.g., the typologies of Christian-Jewish polemics discussed below at notes 97 and 165 .

17 See, e.g., Lutz-Bachmann and Fidora, Juden, Christen und Muslime; Abulafia, Christians and Jews in Dispute; Limor, Disputationen; Lewis and Niewöhner, Religionsgespräche im Mittelalter; Yuval and Ben-Shalom (eds.), Conflict and Religious Conversation.

18 On this distinction, see Dascal, On the Uses of Argumentative Reason, 9-13.

19 On the concept of religion during the medieval centuries, see now Weltecke, Religion vor der >Religion<, with references; for late Antiquity and the modern period, see also Barton and Boyarin, Imagine No Religion; Nongbri, Before Religion.

20 As observed by Wiegers, Fuzzy Categories, 745, publications such as the article on religious polemics in the 2005 Encyclopedia of Religion (Berger et. al., Polemics) focus on inter-religious polemics as a matter of course; according to the bibliography assembled in Snoek, Religious Polemics in Context, it is the most active field.

21 An interesting case in point is the inquisitor's handbook authored by the Dominican friar Bernard Gui ( $\dagger$ 1331), Practica inquisitionis, ed. Douais.

22 On Max Weber's approach (studying ideal types of religious actors like priests, prophets and sorcerers in conjunction), see the take by Bourdieu, Genèse et structure du champ réligieux; and cf. Grundmann, Religious Movements in the Middle Ages. 
views of Pagans, Jews, Muslims, heretics and Orthodox Christianity, ${ }^{23}$ most research takes place within a framework separating polemics between Christians, Muslims, and Jews (or other inter-religious constellations) from polemics concerning heresy, and finally from polemical discourses labelled anticlericalism or satire. ${ }^{24}$ Several recent contributions have made the case for the bridging of this divide, but much of the practical work of connecting the separate research fields still remains to be done. ${ }^{25}$

If we hope to discuss the many diverse but related forms of medieval religious polemics in a connected perspective, or to follow the spread of polemical arguments and rhetorical strategies into non-polemical genres within different pre-modern societies, the current, fairly diffuse understanding of religious polemic must become a hindrance. The term needs to be clarified and differentiated - aiming at an operationalization which is broad enough to encompass quite different cultural forms of polemics, but precise enough to allow exchange about significant differences and similarities.

Recent publications have repeatedly offered new overviews and definitions of "polemic", with or without connection to religion, and have offered several clear and at times compact definitions. ${ }^{26}$ As I suspect, however, we will probably not attain the necessary broad yet precise approach to the phenomenon of religious polemics by reducing extant differences in perspective to one clear solution. Such definitions will always favour one type or genre of polemics over another. If we hope to enable more interdisciplinarity, it seems more promising to compile and compare the different elements which have been highlighted as central for religious polemics. Building on a differentiated list of different elements or dimensions of polemics, we might then work towards an open, extendable morphology of different forms of polemical discourse, which can be engaged with and added to by different disciplinary perspectives.

The present article attempts to offer first observations in this direction. Given the sheer range and complexity of the field, it is clear that its view must necessarily be narrow, as well as uneven. The discussion presented here cannot but be influenced by its author's personal interests, namely those of a historian interested in medieval Latin Christianity and intraChristian polemics. The following observations are very obviously restricted in regional scope by the academic background familiar to me, that of the study of the Euro-Mediterranean area and indeed mostly of western Europe. They are to be understood as preliminary, especially in the bibliography - but the article is intended as an express invitation to specialists in other areas and disciplines to engage with this limited view. It begins with a brief overview of three typical connotations of «religious polemics « and the different research interests which have been connected to their study within European academic settings. It then presents an analysis of current definitions of religious "polemic " and an exploration of their constituent elements, which also comments on the state of research and raises potential questions where

23 Goetz, Wahrnehmung anderer Religionen.

24 On anticlericalism and satire, see, e.g., Dykema and Oberman, Anticlericalism in Late Medieval and Early Modern Europe; Höckelmann, Antiklerikalismus und Exklusionsrhetorik; Hureau, Apparition de thèmes anticléricales; on satire, see, e.g., McGuire, Anticlerical Invective; Steckel, Satirical Depictions of Monastic Life.

25 See Jaspert, Communicating Vessels; Weltecke, Space, Entanglement, and Decentralization; Pietsch and Steckel, New Religious Movements before Modernity.

26 One of the best current short definitions is Southcombe et. al., Introduction, 6. 
this seems appropriate. In a third, concluding part, the article briefly explores how a more differentiated and interdisciplinary approach towards religious polemics might broaden the field of research of Latin Christian polemics, suggesting that a more dynamic understanding would allow us better access to discourses which only "verge on the polemical«, and to the complex but important relationship between inter-religious and intra-religious polemics.

\section{Connotations of "religious polemics" within European medieval studies: a sketch}

So far, no in-depth studies of the modern historiography concerning itself with religious polemics seem to be at hand ${ }^{27}$ - and any such studies would have to deal with a complex, by tradition interdisciplinary field. Still, an analysis of recent overviews and encyclopedia articles suggests that we can pragmatically distinguish three main emphases in the understanding of "polemics «. ${ }^{28}$ These different approaches appear to derive from distinct (if overlapping) contexts and diverging scholarly intentions over the last decades and even centuries, which may be sketched out very briefly here to give an impression of the contours of the related fields. This brief tour d'horizon will also serve to contextualize the diverging definitions of polemic discussed in the following section.

The most specialized fields of research, which apply historical, philological, philosophical or theological analysis to inter-religious encounter, often appear to use the term "religious polemic « in a fairly neutral manner, taking it to denote forms of religious controversy. ${ }^{29}$ Scholars working in the relevant fields often refer to the textual traditions of inter-religious dialogic texts resulting from historical exchanges, i.e. to polemics as constituted by specific textual genres. ${ }^{30}$ Though far removed from these roots by now, this approach ultimately appears to derive from the very heyday of religious polemics in Europe, the seventeenth and eighteenth centuries, when the theological faculties and the overarching imagined community of intellectuals, the Respublica Litteraria, developed an elaborate culture of confessionallyoriented theological polemics, which eventually also influenced the debate culture of politics, art and literature..$^{31}$ In this cultural constellation, the term "polemic «, first appearing during the seventeenth century, eventually came to describe an accepted academic sub-discipline, labelled theologia polemica. ${ }^{32}$ Together with its counterpart, apologetics, ${ }^{33}$ this polemical theology was considered a legitimate scholarly pursuit, and the term "polemics" could therefore be used without devaluing overtones. In contrast to later, narrower definitions of

27 But see the bibliographie raisonnée offered by Snoek, Religious Polemics in Context. Bibliographies on particular polemical traditions are listed in Berger et. al., Polemics.

28 The following sections 2 and 3 draw strongly on the overviews by Sère, Introduction; Southcombe et. al., Introduction; Hettema and Van der Kooj, Introduction. Among encyclopedia articles and shorter essays, see Stauffer, Polemik; Cancik, Apologetik/Polemik; Stenzel, Rhetorischer Manichäismus.

29 See, e.g,. Stauffer, Polemik, 1403.

30 See the literature at n. 17 above. Many dedicated studies also include dialogic polemics taking other forms, such as letters or sermons, see, e.g., Trautner-Kromann, Shield and Sword, 5-10.

31 See, e.g., Bremer and Spoerhase, Gelehrte Polemik. Intellektuelle Konfliktverschärfungen; Bremer and Spoerhase (eds.), "Theologisch-polemisch-poetische Sachen".

32 See Stauffer, Polemik, 1407-1408 and, e.g., Pietsch, Isaac de la Peyrère, 38.

33 For a discussion of the possible dimensions of apologetics, see Krech and Schwartz, Religious Apologetics. 
polemics, no connotation of unscholarly or illegitimate argumentation was implied. Even today, we thus find Opera omnia editions of celebrated medieval authors, such as Thomas Aquinas or Jan Hus, containing volumes of their Opera polemica, simply denoting their treatises on controversial subjects. ${ }^{34}$ Though modern research typically dropped the confessional or religious positioning inherent in historical theologia polemica, it has, in part, preserved the broad, open understanding, which simply defines polemics as engagement between different religious groups.

A second, much more critical understanding of the term has more recent connotations but can equally be traced back to the confessionalized landscapes of early modern Europe. ${ }^{35}$ Once confessional divisions within Europe had fully settled during the seventeenth century, controversial debate lost much of its usefulness. Many theologians, now often writing from institutionally secured positions, came to prefer irenical strategies of argumentation instead, and derailed opponents' attacks by accusing them of illegitimate and unscholarly argumentation. ${ }^{36}$ This ideal also drew on values established within the Respublica Litteraria, such as impartiality and fair rules of engagement. ${ }^{37}$ Such normative ideals of regulated scholarly debate were eventually taken up within the realms of politics, art and literature, where a lively style of polemical debate had established itself by the eighteenth century. But they gained decisive weight during the professionalization, "scientification " and institutional differentiation of the European universities during the nineteenth century: scholars and scientists now aspired to form a separate and independent, "objective" societal sphere, forcing a divestment from the spheres of religious/confessional, literary and political debate. ${ }^{38}$ This aspirational ideal of objectivity implied that debates should focus on their controversial issues as objects of analysis, and not treat them as bones of contention in a fight between two or more actors already divided by political, religious or personal conflict. ${ }^{39}$ The "scientific « and "polemical« thus had to part ways, and scholarly identity-building eventually produced a strong preference for analytical and strictly unemotional argumentation and devaluation of persuasive rhetoric. During the twentieth century and especially after the Second World War, this idea was then reappropriated for the political sphere by thinkers intent on the establishment of a democratic debate culture. Public intellectuals as different as Jürgen Habermas and Michel Foucault postulated that (political, but also scholarly) debate should be located within its own deliberative sphere, free and distinct from the power relations and social pressures of society. ${ }^{40}$ Foucault famously attacked polemical engagement in an interview passage which was itself highly polemical. He criticized polemic as a form of argumentation transgressing the limits of open-ended scholarly debate, as its participants attempted to illicitly dominate the sphere of debate. ${ }^{41}$

34 See the list of works of Aquinas at www.corpusthomisticum.org/iopera.html (accessed 22.12.2017); Jan Hus, Magistri Iohannis Hus Polemica, ed. Eršil et al.

35 Cf. Stauffer, Polemik, 1407-1408; Bremer and Spoerhase, Rhetorische Rücksichtslosigkeit.

36 See, e.g., Hirschi, Piraten der Gelehrtenrepublik; Garloff, Irenik, Gelehrsamkeit und Politik.

37 See, e.g., Murphy and Traninger, Emergence of Impartiality.

38 See generally Rüegg, Universities; for the relation of universities and the public sphere Ash, Wissenschaft(en) und Öffentlichkeit(en).

39 See Daston and Galison, Objectivity; Murphy and Traninger, Emergence of Impartiality.

40 See, e.g., Love, Foucault and Habermas; Lubenow, Public Sphere and Deliberative Democracy. On ancient and medieval ideas of free speech, see Van Renswoude and Baumgartner, Censorship, Free Speech and Religion.

41 Foucault, Polemics, Politics and Problematizations, 112. 
This critical view of polemics as illicit argumentation had a strong influence on modern research, as well as the popular usage of the term polemic. Though this critical view did not affect the study of inter-religious polemics deeply, its influence can be felt indirectly in some fields of Medieval Studies, for example the study of some intra-Christian polemics, ${ }^{42}$ where aggressive rhetoric was treated as an embarrassment and separated from scholarly argumentation. More generally, the modern ideal of impartial, open debate exerted influence on research concerning medieval debate culture and learning. Seen in hindsight, this modern ideal attached itself very easily to research perspectives organized along narratives of modernization, prominent within the subfields of medieval intellectual history during the 1960s, 70 s and 8os, which focused on the alleged medieval origins of modern rationality and scientific thought, or on "medieval humanism $\aleph^{43}$ as for example works by Sir Richard W. Southern, a strong proponent of modernization narratives who was to become the doyen of the anglophone intellectual history of the western European High Middle Ages. In his early study of Western images of Islam, Southern argued that medieval Christian perceptions of Islam might not have accepted or even understood Islam. But he still postulated that Western views grew more accurate and rational during the later Middle Ages, asserting that »the statement of the problem became more complex, more rational, and more related to experience ${ }^{44}[\ldots]$.. In this and in similar studies, it was, of course, not denied that Christian authors engaged in polemics with their religious opponents - but within a narrative arc focusing on progress towards modernity, instances of polemics were hardly ever analysed in any depth or given much prominence. This trajectory was soon criticized, which leads us to a third, almost diametrically opposed understanding of polemics which is very common in the youngest layer of research.

The background of this third, current understanding of the polemical is broad and interdisciplinary. Overall, it appears to have been shaped by postmodern and postcolonial perspectives on cultural identities, cultural hierarchies, and the violence underpinning them, a complex of issues which has proved highly relevant and indeed transformative for Medieval Studies ${ }^{45}$ Research fields influenced by these questions were not necessarily focused on religious polemics, but often made use of the term "polemic/polemical« to denote disparagement or aggressive, degrading speech, linked to concepts of intellectual violence such as those studied by Judith Butler's Excitable Speech, but also to various practices of cultural "othering" enabling physical violence. ${ }^{46}$

42 For an example, see Steckel, Une querelle des theologiens.

43 The pioneering study is Southern, Medieval Humanism, but see also his later Scholastic Humanism. Other perspectives insisted on the scientific nature of medieval thought (see, e.g., the reconstruction of Marie-Dominique Chenu's approach in Donneaud, Histoire d'une histoire) or refer to the Enlightenment, like Flasch and Jeck, Licht der Vernunft.

44 Southern, Western Views of Islam, 91-92.

45 For direct engagement with Postcolonial theory, see, e.g., Cohen, Postcolonial Middle Ages; Altschul, Postcolonialism and the Study of the Middle Ages; Gaunt, Can the Middle Ages be Postcolonial. It should be noted that much of the reception of relevant approaches in Medieval Studies took place indirectly, with reference to broader concepts of cultural history, transcultural history and connected/entangled history. On these concepts, see, e.g., the overviews in Hovden et. al. (eds.), Meanings of Community; Drews and Scholl, Transkulturelle Verflechtungsprozesse; Tolan and El Anabi (eds.), Identités en mutation; Krech and Steinicke, Dynamics in the History of Religion; Borgolte und Schneidmüller (eds.), Hybride Kulturen im mittelalterlichen Europa.

46 See the contributions in Azoulay and Boucheron (eds.), Le mot qui tue; Suerbaum et. al., Polemics; as well as Butler, Excitable Speech. 
This shift added a third and youngest layer of connotations to the concept of "polemic", now linking it to cultural hierarchies: the term no longer emphasized a body of texts and the positions articulated therein, or a form of argumentation which is somehow illegitimate, but rather a form of discourse aiming to disparage or devalue an opponent. Importantly, cultural devaluation and disparagement were now understood to take several forms, either using scholarly, purportedly objective argument or rhetorical aggression, invective and degradation. This usage thus cuts across older definitions of the polemical - in fact, the very boundary between legitimate and illegitimate, scholarly and non-scholarly forms of argumentation is shown to be dependent upon cultural hierarchies and the power relations undergirding them. As Edward Said's pioneering Orientalism classically set out in 1978, perceptions of cultural identity cannot be neatly classified into objective and rational scholarly discourses on one side and tendentious polemic on the other. Ideas of identity and alterity, which accumulate over long periods of time, instead typically permeate both scholarly and popular discourses, and may be deeply ingrained into the foundations of a society, including its academic institutions and disciplines. As Said pointed out in critical engagement with the optimistic modernization narratives of the 1960 s and 1970s, the application of scholarly thought to cultural prejudices (for example to historical religious polemics) may thus not only lead to their deconstruction, but also to a "scientification " and strengthening of these prejudices. Speaking about the assumed boundary between a more or less rational perception of religious others, Said specifically engaged with Southern's presentation of a growing rationalization of western views of Islam: as he pointed out, Southern did not observe "some body of positive Western knowledge which increases in size and accuracy [...] « but »Western ignorance which becomes more refined and complex [...]. For fictions have their own logic and their own dialectic of growth or decline. $\aleph^{47}$ Said's study thus cautions against a separation of more or less rational and irrational perceptions of cultural identities. A polemical dimension, in the sense of a devaluation of the religious opponent, may very well be present in elaborate, rational scholarly reasoning presenting itself as pointedly objective.

Though this theoretical perspective informs most areas of the study of religious polemics today, its focus on the cultural construction of identity and alterity has tended to direct attention away from the term "polemic « itself. Typically, the emphasis was on other analytical terms, most importantly on identities and techniques of "othering «. ${ }^{8}$ Other research has focused on persecution, studying physical violence and its legal underpinnings, ${ }^{49}$ or on symbolic or visual degradations..$^{50}$ Art historical approaches have developed fascinating perspectives on images depicting otherness and monstrosity. ${ }^{51}$ In other research areas, the focus has been on rhetorical and literary techniques of disparagement. The term "polemic " was often used in these approaches but not typically clearly defined. But ultimately, this more recent research seems to presuppose a fairly narrow understanding of polemics, equating it with forms of cultural disparagement.

\footnotetext{
47 Said, Orientalism, 62.

48 See below at note 119 .

49 See especially Iogna-Prat, Order and Exclusion; Moore, Formation of a Persecuting Society; Nirenberg, Communities of Violence; Holzem, Krieg und Christentum; recently, see also Koch, Patterns Legitimizing Political Violence.

50 See, e.g., Groebner, Defaced; Cuffel, Gendering Disgust; Abulafia, Religious Violence between Christians and Jews; and several contributions in Azoulay and Boucheron, Le mot qui tue.

51 See, e.g., Strickland, Saracens, Demons and Jews; Trivellone, Hérétique imaginé; Epstein, Dreams of Subversion.
} 


\section{Constituents and dimensions of the polemical: a preliminary checklist}

As set out above, the tensions within these research fields and the need to accommodate different, only partially overlapping research interests as well as highly diverse forms of religious polemics appear to make it more meaningful to assemble a typology of religious polemics rather than attempting a stringent definition. A necessarily modest starting point for further interdisciplinary work may be formulated in a composite definition or sconstituent checklist،, enumerating features or dimensions ascribed to medieval religious polemics.

Building on the definitions suggested in extant research, and particularly in some recent works which have sought to engage with the phenomenon and offered their own definitions, ${ }^{52}$ the present, preliminary checklist distinguishes eight different features which may appear in medieval polemical discourses (understood to include performance, text and images, though the focus is, admittedly, on texts). As I will discuss in the concluding section, discourses which only "verged on the polemical « might display one or two of these features, while discourses with the central intent to engage with a religious opponent often displayed several of them. In the following, the condensed list will be followed by a longer explanatory discussion engaging with relevant research. The list distinguishes two broad sets of elements.

The first four interrelated and partially overlapping characteristics concern the concrete realizations and social functions of polemical discourses, especially those polemics openly seeking to disparage an opponent:

(1.) Disparaging categorization: on the level of concrete utterances, polemical discourses made use of pre-existing cultural categories and hierarchies to devalue opponents.

(2.) Rhetorical aggression: polemical discourses often employed aggressive speech, using conventionalized rhetorical techniques and repertoires to attack an opponent's position while defending and extolling the speaker's own.

(3.) Public character and double audience: polemical engagements typically had a twofold audience and thus opened debate to a public (however circumscribed). They could be addressed primarily to a religious opponent or outgroup, or to an audience considered the speaker's ingroup, which was to be mobilized against the opponent. Often, polemical discourses addressed both of these audiences.

(4.) Construction of self and other: seen from a mid- and long-term perspective, polemics contributed to the construction and defence of complex cultural identities, usually by adapting pre-existing traditions to contrast the religious self with an other.

The second group of four characteristics concerns the methodologies and conflict strategies of polemical engagements, especially those engaging in scholarly argumentation.

(5.) Debatable legitimacy: polemical engagements could transgress the limits of legitimate argumentation or procedure in a given historical circumstance, or trigger arguments over such limits.

(6.) Pre-determined stances: some polemical engagements were conducted with a predetermined attitude and lacked open-endedness, as the polemical speakers felt that truth was already in their possession.

52 See n. 28 above. 
(7.) Scholarly methodologies: polemical engagements could draw on established practices of debate or scholarly methods to elaborate their religious standpoints, or produce specific agreements and compromises regarding such methodologies.

(8.) Epistemological asymmetries: polemical engagements might also be conducted within asymmetrical epistemological or methodological frameworks or produce such asymmetries, leading to a devaluation of the opponent's assessment of truth and preferred methodology.

\section{(1.) Disparaging categorization}

On the level of concrete utterances, polemical discourses make use of pre-existing cultural categories and hierarchies to disparage or devalue opponents. Though the term "polemical« today mainly evokes associations of aggressive speech, there can be no degradation or devaluation of opponents without underlying categories which established religious and cultural difference and assigned cultural hierarchy. ${ }^{53}$ Disparaging categories and hierarchies might then form the basis for disparaging rhetoric, and could, moreover, develop considerable impact if they became the foundation for legal or other normative categorizations. ${ }^{54}$ Conversely, a classification sorting an opponent into a pre-existing, negatively connotated category works quite well even today without aggressive verbal embellishment. In certain contexts, it can be derogatory to simply say "she is a woman!«. To cite a popular twentiethcentury phrase, a male opponent can be disparaged by claiming that he throws, runs or cries »like a girl«. This latter example, a polemical comparison, and thus a specific form of disparaging categorization, ${ }^{55}$ illustrates the force of categorization: to class a male opponent in a way which likens him to a woman or child is to question the opponent's value, marking him as deficient as a man or adult. A particularly popular, almost universal variant of this form of devaluation is the comparison (or identification) of humans with animals, especially animals considered impure, such as pigs or dogs, which denied the very humanity of the opponents and made open or implicit arguments for the necessity of guiding, controlling or even exterminating them..$^{56}$ In passing, it may be observed that polemics could emphasize the negative meaning of ambiguous or polyvalent categories. A male scholar might, for example, ascribe positive female roles of mothering to himself, while still ascribing negative female traits to a male opponent to disparage him. ${ }^{57}$

53 On this fundamental issue, see Azoulay and Boucheron, Violences intellectuelles, 44-48.

54 This point is made in depth by Moore, Formation of a Persecuting Society; Iogna-Prat, Order and Exclusion, and others.

55 On the use of comparisons to establish cultural hierarchies, see, e.g., Cavarzere, Comparative Method; Epple, Doing Comparisons, and in the future Brauner and Steckel, Wie die Heiden - Wie die Papisten.

56 On animal metaphors in medieval inter-religious polemics, see Cuffel, Gendering Disgust, 198-239. Particular themes include the Judensau, cf. Shachar, Judensau; Wiedl, Laughing at the Beast. On dogs, see, e.g., Resnick, Good Dog/Bad Dog. On the polemical use of animal metaphors in literary forms such as the beast epic, cf. the contributions in Scheuer and Vedder, Tier im Text; Lembke, Biblical Creatures.

57 See Cuffel, Ibn Sahula's Meshal Ha-Qadmoni. 
Many categories employed in disparaging categorizations are common in several religious traditions and in intra- as well as inter-religious polemics. This appears partly due to the fact that they revolve around basic anthropological constants: much disparagement is based on gender and age, on humanity versus animal nature, on the natural as opposed to the unnatural, the healthy as opposed to the sick, the pure as opposed to the impure. But in the wake of influential studies like Mary Douglas's "Purity and danger,$^{58}$ research has mostly emphasized distinct cultural forms. As Douglas argued, the cultural construction of purity and pollution appears strongly linked to concepts of social order in most societies. Yet cultural differences might still lead to divergent reactions and perceptions in encounters between culturally different protagonists. Within the Islamicate world, for example, we encounter polemics against blue- and green-eyed people, which build on the understanding of blue eyes, which were considered unremarkable in other regions, as unnatural or sick. ${ }^{59}$ Recently, however, several studies have highlighted that polemical engagement between religious traditions might also cause the convergence of cultural assumptions, as, for example, in the development of shared perceptions of corporeal and sexual impurity among high medieval Jewish and Christian interlocutors, ${ }^{60}$ or in related rules governing the proper use of food. ${ }^{61}$

A comparative perspective on disparaging categorizations also highlights that confrontations often revolved around the differentiation of religion from other societal spheres or fields: controversies between different religious groups often emphasized their different understanding of the ideal relationship of religious norms to other spheres, such as scholarly, economic or political practices. ${ }^{62}$ Both in Christian-Jewish encounters and in many dissenting movements within medieval Christianity, for example, the religious regulation of business practices and attitudes towards money and riches became highly contested. The debates and eventual polemics generated by these conflicts caused several categories negotiating the boundaries of religious and economic life (such as greed, avarice, usury, or deceit) to take on new symbolic charges, which made them more apt for disparagement and connected them to specific groups, such as the usurious Jews and the greedy Christian prelates. An even more strongly instrumentalized relationship is that of religion and scholarship: besides many references to categories regulating morality, the strong emphasis on intellectual contest typical for Judaism, Christianity or Islam led to an early insistence on the categories of (intellectual) blindness and insanity, i.e. deficiencies in cognition and human rationality, as well as accusations of a lack of intellectual or scholarly competence. ${ }^{63}$

58 Douglas, Purity and Danger; cf. also Duschinksy et. al., Purity and Danger Now.

59 Richardson, Blue and Green Eyes. See also, generally, Kim, Reframing Race and Christian/Jewish Relations.

60 See Cuffel, Gendering Disgust; Marcus, Christian-Jewish Symbiosis.

61 Freidenreich, Foreigners and their Food.

62 On the historical differentiation of religion, see Bourdieu, Gènese et structure du champ réligieux; I am currently preparing an article on the subject entitled The medieval religious field. Framing processes of religious transformation in late medieval and early modern Europe.

63 For ancient foundations, cf. Opelt, Lateinische Schimpfwörter, 228-237, for the Christian tradition, cf. Opelt, Polemik in der christlichen lateinischen Literatur. On types of disparagement, see also Destemberg, Espace public de la polémique, at nn. 26-35. 
Another relevant class is constituted by different categories negotiating the intersection of religion and the realm of (religious) law. ${ }^{64}$ There has already been substantial analysis of the way legal discourses constituted religious differences and interfaced with the realm of the political in the imposition of sanctions or outright persecution. Important studies on high medieval Latin Christianity, such as Robert I. Moore's hypothesis of the "formation of a persecuting society" during the High Middle Ages and Dominique Iogna-Prat's study of the religious "order and exclusion" envisioned by the Cluniac abbot Peter the Venerable († 1156), have emphasized the marked consequences which legal and theological systematization had on the perception and eventual persecution of religious difference. ${ }^{65}$ But the argument they make for Christianity might be applied more widely: the specific class of categories straddling the spheres of law and religion - i.e. categories defining the boundary of the religious community, such as heresy, unbelief, apostasy or blasphemy - constitutes a particular field of interest for comparative and connected studies, such as Christine Caldwell Ames' recent monograph on heresies in medieval Christianity, Judaism and Islam. ${ }^{66}$ Recent research has already highlighted further types of polemical categorizations which draw on religious, legal and political connotations. A particular form of categorization highlighted in comparative research consists in the identification of religious opponents with apocalyptic figures and groups, ${ }^{67}$ such as the Antichrist, Gog and Magog, or the hypocritical harbingers of the Antichrist. ${ }^{68}$ Comparative approaches might also profit from the study of a complex category like hypocrisy, which negotiated the boundary of the religious field by implying that an opponent was not a "real « Christian, Muslim or Jew, but only possessed a semblance of genuine religiosity. ${ }^{69}$

Of course, any comparative or connected work will have to invest considerable energy in the reconstruction of the genealogies of some particularly charged categories. An intriguing type of categorization, for example, consists in coded or metaphorical names, i.e. negatively charged religious or ethnic labels, such as "Pharisees «, often drawn from normative or sacred texts and applied figuratively to mask the object of a polemical attack. Especially in situations where the power balance did not allow polemical authors to engage a powerful opponent directly, such covert polemics - for example addressed to unnamed "hypocrites" - could open up the possibility of presenting fairly complex arguments..$^{70}$ Whereas some polemical labels became commonplace and took on the quality of easily-understood insults, as seems to have been the case with the "Goliardi« of Latin satire,${ }^{71}$ other pseudonymously attacked

64 See, e.g., the volume series Tolan et. al. (eds.), Religion, Minorities and the State, e.g. Tolan and Boisselier, Religious Cohabitation; Tolan et. al., Jews in Early Christian Law; Fierro and Tolan, Legal Status of Dimmi-s.

65 Moore, Formation of a Persecuting Society; Iogna-Prat, Order and Exclusion.

66 Ames, Medieval Heresies.

67 See generally Kienzle, Preaching as Touchstone; Schmieder, Prophetische Propaganda in der Politik.

68 For examples, see, e.g., Brandes et. al., Peoples of the Apocalypse.

69 On hypocrisy in different cultures see, e.g., Adang, Hypocrites and Hypocrisy; Elmer, Pillars, Hypocrites and False Brothers; Steckel, Falsche Heilige; Emmerson and Herzmann, Apocalyptic Age of Hypocrisy; Berger, Introduction, 96.

70 See, e.g., Emmerson and Herzman, Apocalyptic Age of Hypocrisy; Steckel, Ein brennendes Feuer in meiner Brust, with examples from Latin Christianity.

71 See, e.g., Mann, Satiric Subject and Satiric Object. 
groups could only be identified by audiences possessing specific background knowledge. In some cases, the decoding of addressees, or the reconstruction of the message such polemics expressed »between the lines", could demand considerable sophistication on the part of the audience. $^{72}$

\section{(2.) Rhetorical aggression}

On the basis of different cultural categories and hierarchies, polemical discourses often made use of aggressive speech, using specific rhetorical repertoires and techniques to attack an opponent's position while defending and extolling the speaker's own. In the introduction to their recent volume, Southcombe, Suerbaum and Thompson thus begin their definition of polemic by describing "strong and hostile language, suggestive of violence and warfare ${ }^{73}$ Alain de Libera, Bénédicte Sère and others have also emphasized the "agonality« of Christian scholasticism, which imbued medieval and early modern techniques of debate and led to the cultivation of a vocabulary of intellectual warfare and battle. ${ }^{74}$ Jürgen Stenzel characterizes polemic by highlighting its confrontational $»$ rhetorical Manichaeism ${ }^{75}$ which polarized a debate and painted the self and the other in stark black and white. However, more precise descriptions of the aggressiveness or violence of polemics are surprisingly hard to find - probably because there are many possible levels and approaches as well as different languages and rhetorical traditions to explore. Examples for some of them in the following are drawn from the rhetorics of Christian medieval Latinity.

Generally, one may note that the rhetoric used in engaging the person of an opponent often draws on the semantic field and registers of warfare in the Latin Middle Ages - but this is by no means the only prominent field. Quite often, vocabulary referring to intellectual engagement as warfare or battle actually pursued an irenical strategy, stressing the polemicist's aversion to violence and ascribing illegitimate violence to the opponent. ${ }^{76}$ As mentioned in the discussion of categorization, the issues of moral deficiency, but also of intellectual deficiency or physical deformity played a role. ${ }^{77} \mathrm{~A}$ cross-disciplinary overview of typical themes of invective or offensive speech appears to be lacking, even within the realm of Latin. ${ }^{78}$

72 On the reading of subtexts and identification of esoteric meaning, see classically Strauss, Persecution and the Art of Writing; for covert biblical polemics see Amit, Hidden Polemics in Biblical Narrative.

73 Southcombe et. al., Introduction, 6.

74 See Sère, Thomas d'Aquin, with reference to De Libera, Penser au Moyen Age, 155; Destemberg, Espace public; Füssel, Gelehrtenrepublik im Kriegszustand.

75 Stenzel, Rhetorischer Manichäismus.

76 Cf. Destemberg, Espace public, at n. 40; see also the examples cited ibid., at note 7-8.

77 See the various approaches in Cuffel, Gendering Disgust; Desmons and Paveau, Outrages, insultes, blasphèmes et injures; Opelt, Lateinische Schimpfwörter; Opelt, Polemik in der christlichen lateinischen Literatur.

78 But see the catalogues developed by Opelt, Lateinische Schimpfwörter; eadem, Polemik in der christlichen lateinischen Literatur; Destemberg, Espace public, at n. 25-35; Dahan, Intellectuels chrétiens, 361-421; Kienzle, Preaching as Touchstone. 
In general, research on the rhetorical norms governing polemical engagements in Latin appears surprisingly fragmented. The Latin Middle Ages inherited the concepts of vituperatio and invectiva ${ }^{79}$ from Antiquity, but the ancient handbooks of rhetoric yielded few concrete patterns, and literary examples therefore provided the most important impulses for shaping antagonistic rhetoric. Latin invective, for example, took up impulses from early texts such as Pseudo-Sallust's Invectivae or the church father Jerome's († 415) Contra Rufinum. ${ }^{80}$ Christian rhetoric also elaborated its own modes of public religious speech, such as exhortation, increpatio or admonitio, which blended exhortatory and didactic elements with invective. ${ }^{81}$ Practical advice on different forms of disparagement such as invectiva and satira ${ }^{82}$ was eventually included in poetical handbooks, and influenced the rhetoric of letters and sermons, two genres which lent themselves to polemics very well. ${ }^{83}$ Later on, humanist literary practices rediscovered the ancient form of invective and reinvigorated it. ${ }^{84}$

But of course, practically every device and flourish of rhetorical elocutio could be instrumentalized to lend expressive force to polemical speech. A few typical persuasive operations have been highlighted: polemical rhetoric tended to polarize, creating black and white options. Polemicists typically also accentuated any uncontroversial points to strengthen their position, while omitting or minimizing the corresponding unfavourable points. Other favourite persuasive techniques include generalization, for example in stereotypes, and insinuation, which anticipated or hypothesized bad intentions or characteristics. ${ }^{85}$ As such cases show, polemical rhetoric may depend largely on the audience for a full reconstruction of its potential meaning. In particular, some forms of "covert « polemics, for example satirical texts with allegorical actors, actually managed to put much of the work of meaning-making onto the shoulders of the audience. Where insider knowledge was necessary to decode covert polemics, this also established a bond (however weak) between the polemicist and the collaborating audience, who shared in the identification of the opponent and might, in cases of a genuinely "esoteric" subtext of a polemic, feel glee or intellectual superiority at being "in the know". In some cases, the decoding might even force the recipient to draw conclusions which only emerged once the polemical argument was »translated « and applied to its actual target. Inviting readers to such reconstructions, which forced them to apply techniques usually cultivated in the allegorical interpretation of literature, of sacred texts or of legal norms, might thus also be considered as a polemical strategy, so far mainly investigated for poetical texts and especially animal allegories. ${ }^{86}$

79 Cf. Neumann, Invektive; Helmrath, Streitkultur; Garcia and Beaumatin, Iinvective. On invective in Antiquity, see also Opelt, Lateinische Schimpfwörter.

80 See the discussion in Neumann, Invektive; Helmrath, Streitkultur; Opelt, Lateinische Schimpfwörter; Opelt, Polemik in der christlichen lateinischen Literatur.

81 On admonitio, see De Jong, Admonitio and Criticism of the Ruler; Suchan, Mahnen und Regieren; Weiler, Clerical admonitio. The ongoing dissertation of Andra Alexiu (Münster/Bucarest), Confront and Admonish: Hildegard of Bingen and Female Monastic Agency, will contain a study of twelfth-century admonitio and its use in intra-Christian polemic, cf. her shorter contribution in this volume.

82 On the medieval notions and polemical use of satire, see Kindermann, Satyra; Kendrick, Medieval Satire; and, e.g., McGuire, Anti-Clerical Invective; Levine, Why Praise Jews.

83 Cf. Helmrath, Streitkultur, 262.

84 See, e.g., Helmrath, Streitkultur; Baumann et. al., Polemik im Dialog des Renaissance-Humanismus; Anheim, Humanisme est-il un polémisme.

85 Cf. Stenzel, Rhetorischer Manichäismus, 7-8.

86 See the literature above, n. 55., and see the remarks in Doležalová, Passion and Passion. 
A particularly intriguing aspect of medieval (and modern) rhetoric is often acknowledged, but lacks systematic or comparative treatment for polemical discourses so far: polemical engagements often attempted to evoke physical and emotional reactions in their audience. Following and reflecting upon the precepts of the ancients, such as Aristotle's Rhetoric, many medieval Latin polemics developed highly functional techniques of appealing to and instrumentalizing emotions. But there are, as yet, only a few studies linking the theme of polemics to the thriving research area of the history of emotions, ${ }^{87}$ which is currently offering many new impulses for research interested in the emotional standards and emotional regimes visible in particular historical constellations.

Given the polarization and instrumentalization of emotions in current political cultures and social media, this topic appears highly relevant, and further research could profit from the work already done in a number of different sub-fields. Some research, like Alexandra Cuffel's important study of the use of gendered polemics of disgust in medieval inter-religious encounter, has looked at the use of the body in religious polemics. ${ }^{88}$ Drawing on the assumption that concepts of impurity and inappropriateness shape affective regimes, Cuffel analyses polemical references to disease or deformed bodies. As she reminds us, such techniques might generate an immediate, visceral reaction of disgust, which audiences could not fully control or subject to rational evaluation..$^{89}$ Another approach has focused on techniques of shaming or of challenging an opponent's honour, which often formed part of polemical encounters. ${ }^{90}$ Several studies have also dealt with the use of ridicule as a means of disparaging an opponent, ${ }^{91}$ in particular with satire, which has drawn interest in literary as well as historical studies. ${ }^{92} \mathrm{~A}$ further promising field seems to lie in polemical strategies which consciously activated emotionally charged subjects, such as the desecration of holy places or the killing of women and children, ${ }^{93}$ or try to overwhelm listeners with feelings of rightful indignation, anger, or fear to lock them into pre-defined scripts for specific emotional reactions meant to trigger actions. Scholars working on pre-modern periods might perhaps even look towards the analysis of current political culture to find new frameworks for such forms of polemic, and experiment with theories of "affective polarization ${ }^{94}$ or more generally with the theories of »framing" of multi-layered political messages developed in media studies and political science. ${ }^{95}$

87 See, e.g., Till, Text, Kommunikation und Affekt; Sauer, `Bringing Emotions Back in‘; Clement, Introduction. On the history of emotions, see the recent overviews and discussions in Miller and Wheatley, Emotions, Communities and Difference; Plamper, History of Emotions; Rosenwein, Generations of Feeling; Nagy and Bouquet, Sujet des émotions; Bouquet and Nagy, Sensible Moyen Âge.

88 Cuffel, Gendering Disgust. See also eadem, Matter of Others; for Antiquity, see, e.g., Taylor, Body in Biblical, Christian and Jewish Texts, for the Reformation period, e.g., Scribner, Popular Culture and Popular Movements, 54-69, 295-99.

89 Cuffel, Gendering Disgust, 5-9.

90 See, e.g., the contributions in Groebner, Defaced; Freudenberg, Irarum nutrix; Knappe, Flyting und die Rhetorik des verbalen Konflikts; Smail, Consumption, of Justice, ch. 2; White, Feelings in the Feud.

91 See, e.g., Scharff, Lachen über Ketzer; Zellentin, Rabbinic Parodies; Röcke and Velten, Lachgemeinschaften; Classen, Laughter in the Middle Ages.

92 See the literature in n. 81 above and, e.g., Cailly, Les fabliaux; Mann, Chaucer and Medieval Estates Satire; Burrows, Stereotype of the Priest; Schüppert, Kirchenkritik in der lateinischen Lyrik.

93 See, e.g., the observations in Signori, Frauen, Kinder, Greise und Tyrannen; Shalev-Eyni, Martyrdom and Sexuality.

94 See, e.g., Lau et. al., Effect of Media Environment Diversity; Marcus et. al., Affective Intelligence; Iyengar and Westwood, Fear and Loathing across Party Lines.

95 See, e.g., Lakoff and Wehling, Your Brain's Politics; Matthes, Framing. 


\section{(3.) Public character and double audience of polemics}

A third characteristic of polemical discourses is that they typically spoke to a twofold audience and thus either utilized or created a public sphere of debate. Polemics could be addressed primarily to a religious opponent, or "outgroup «, or to an audience considered the speaker's "ingroup", which was to be mobilized against the opponent or confirmed in its adherence to the speaker's position..$^{96}$ There is a strong consensus in research that this latter, consolidating or mobilizing function of polemics contributed greatly to the construction of religious identities and frequently affected or even completely overlaid the intention of attacking an outgroup. This issue will be revisited in a moment. As a basis for further discussion, it should first be noted that the distinction between polemics addressed to an internal or towards an external audience is one of ideal types and can be somewhat misleading. Extant work on polemical engagement in fact shows a broad variety of possible audiences and of the possible institutional frameworks and public spaces for polemics, and it is these historical contexts which lie at the heart of any form of contextualization. Any future comparative work, and any attempt to connect different historical strands of religious polemics, will, in fact, have to engage with the constantly changing reception contexts and shifting intended audiences of polemical arguments, which may at first glance appear traditional and repetitive, but often show minuscule changes which need to be tied to specific contexts.

Research on medieval Jewish anti-Christian polemic provides examples which quickly deconstruct the notion that distinctions between different audiences of polemic might be easy to draw. In a useful functional classification of such texts, Jeffrey Cohen has highlighted four functional types of anti-Christian polemic from the medieval centuries, ${ }^{97}$ which can, for the purposes of this overview, be grouped into three different types primarily addressing Jewish audiences, and one type primarily addressing Christian interlocutors and persecutors. As Cohen outlines, the relatively low intellectual engagement between Christians and Jews during the early medieval centuries led to an adaptation of the polemics developed during late Antiquity. The intellectual exchange which had accompanied the "parting of the ways « ${ }^{98}$ was largely supplanted by inward-looking texts, "polemic for the community of the faithful «, ${ }^{99}$ for example the derogatory folktales of the Toledot Yeshu, or liturgical poetry evoking anti-Christian sentiments, which mainly served to confirm Jewish identity. ${ }^{100}$ But this type of polemic was complemented when intellectual engagement resumed during the twelfth century: a new type of polemical texts still addressed Jews as their proximate audience, but mainly functioned as "guidebooks for direct confrontation ", offering arguments and authorities which might be used for disputations with an ultimate audience of Christian opponents. ${ }^{101}$ From the thirteenth century onwards, a third type of polemics then reflected a shift in circumstances towards a "defence of the faith [...] on trial«, which was geared much more towards the Christian opponents of Jewish authors because the institutional framework of

96 Thus, e.g., Southcombe et. al., Introduction, 6; Stauffer, Polemik, 1403; Hettema and Van der Kooj, Introduction, xiv-xv.

97 Cohen, Towards a Functional Classification.

98 Cf. Boyarin, Border Lines; Becker and Reed, Ways That Never Parted.

99 Cf. Cohen, Towards a Functional Classification, 94-99, at 94.

100 See, recently, Cuffel, Between Epic Entertainment and Polemical Exegesis.

101 Cohen, Towards a Functional Classification, 99-104.

medieval worlds $\bullet$ No. $7 \cdot 2018 \cdot 2-60$ 
encounter had shifted. Jewish communities were now under mounting pressure from Christian persecution, and Christian polemicists were beginning to charge Jewish scholars with alleged deviance from the tenets of genuine Judaism, and thus a form of heresy. Though new polemical texts of this period were still often based on situations of disputation, and still gathered arguments which might be used by Jews in further engagements, such encounters were increasingly shaped by coercion and the threat of physical violence. This highly asymmetrical power balance skewed the trajectory of argumentation on the side of Jewish polemicists, causing a highly defensive stance which mainly reflected the agenda of their Christian persecutors. The tensions of the situation at times even forced Jewish polemicists into a more accommodating and tolerant stance towards Christianity, intended, at least in part, to placate a hostile audience of Christians. ${ }^{102}$ Finally, however, a fourth type of polemical text went the opposite way and attacked Christianity more openly, while also addressing itself more firmly to Jewish audiences again. As the late medieval expulsions of the Jews from several European realms and eventual mass conversions of remaining Jews in Iberia heightened the pressure on Jewish communities, a diverging strategy of anti-Christian polemics now engaged in open "condemnations of the aggressor «. Such polemics aimed to discourage the remaining Jews from conversion, showing that Christianity was "not an option «. ${ }^{103}$ This produced much more disparaging and hostile texts, though Jewish authors often engaged with Christianity on an elevated intellectual level as well. Intriguingly, they now transferred and mirrored many accusations which Christian authors had earlier levelled against Judaism, such as deviance from previous, authentic norms.

As this highly compressed overview shows, polemics might not only address themselves to different audiences, but also appeal to these in different ways, shaped by the different legal, intellectual and political constraints on the situation of encounter and by the different political and cultural circumstances of the groups involved. In charting the transformation of particular types of polemics, both these changing contexts and possible shifts in audience - towards the external audience of the outgroup, or towards the ingroup of the polemicist's own community - need to be scrutinized.

Especially in a comparative perspective, however, such further scrutiny will probably also force us to engage more closely with different cultural constellations of "the public«. The public cultures emerging across different medieval societies over the centuries form a highly active if, again, rather fragmented research field, and any attempt to locate polemics within particular public spaces will have to engage with it. ${ }^{104}$ Three distinct issues may be noted for future research.

Firstly and generally, much of the attention which has been devoted to the analysis of medieval public culture (at least for Latin Christianity) has ultimately had a focus on the political public, both in drawing on modern models of the "public sphere of politics such as Jürgen Habermas's celebrated model, and in focusing on highly political debates such as the eleventh- and twelfth-century Investiture Contest with its re-evaluation of the relationship

102 Cohen, Towards a Functional Classification, 104-109.

103 Cohen, Towards a Functional Classification, 109-112.

104 For recent overviews and analyses, see Connell, Popular Opinion in the Middle Ages; Jaspert, Politische Öffentlichkeit im Spätmittelalter; Langer and Fierro, Public Violence. For the publicness of polemics, see the remarks and literature in Destemberg, Espace public. 
of religion and politics. ${ }^{105}$ By contrast, the study of religious polemics throws up the question of how far the structures of public debate generated by religious conflicts might differ from the debating of politics. ${ }^{106}$ To follow up on this approach, we may have to look to other models, for example approaches to the public of the European Reformation ${ }^{107}$ - or, again, engage directly with scholars discussing current political culture.

This leads to a second, related observation: modern models often postulate a "public sphere« or "public space« which, given the singular, appears as a unified structure. Against this, some medievalists have insisted that given the communication practices, media, and group structures of medieval societies, we are mostly faced with overlapping publics or textual communities, many of which remained "occasional « publics, dependent on intermittent meetings of otherwise dispersed elites. ${ }^{108}$ On the other hand, it has been argued that some of the most intense conflicts produced a coherent public sphere, which managed to connect elite and popular discourses to enable genuinely public debate. ${ }^{109}$ In analysing polemical debates and their different venues and institutional frameworks, both argumentations have a bearing: clearly, different sorts of polemical engagements were anchored to different venues of public debate. The constellations which produced specific religious polemics, and, all too often, also violence against religious others, may often have been defined by the circumstances of local "communities of violence ${ }^{110}{ }^{10}$ But at the same time, other forms of religious polemics bridged different venues, contributing to the constitution of public debates in the sense of multi-level discourses debated across interrelated communication networks. ${ }^{111}$ As several scholars have pointed out, urban spaces were particularly apt to act as communication hubs for such religious debates. ${ }^{112}$

Viewed from a mid- and long-term perspective, the public of polemics was continually being constituted and reconstituted, often in a circular pattern which shows episodic reworkings of polemical discourses: polemical texts were produced once discussion in scholarly, legal or political venues had failed to establish a solution for religious conflicts. Either both sides or just the disempowered party of a conflict might take refuge in polemics, attempting

105 Cf. Melve, Inventing the Public Sphere, who advocates an adaptation of the model elaborated in Habermas, Strukturwandel der Öffentlichkeit.

106 That the political sphere developed its own public is argued in Schlögl, Politik beobachten, but no consequences for religion are drawn.

107 Possible models include the observations in Scribner, For the Sake of the Simple Folk; Wohlfeil, Reformatorische Öffentlichkeit; but also recent approaches to late medieval media cultures such as Corbellini, Cultures of Religious Reading.

108 The term »occasional public« was coined by Thum, Öffentlichkeit und Kommunikation. On the fragmented and overlapping nature of medieval networks of public communication, see Jaspert, Politische Öffentlichkeit, 435; Steckel, Professoren in Weltuntergangsstimmung.

109 Melve, Invention of the Public Sphere.

110 See, e.g., Limor, Polemical Varieties, and Nirenberg, Communities of Violence.

111 On the dynamics of large-scale political debates, see, e.g., Sère, Débats d'opinion. On »shared spaces« generated by scholarly exchanges, including polemics, see, e.g., Brentjes, Medieval Portolan Charts; Stroumsa, Thinkers of "This Peninsula«.

112 See, e.g., Symes, A Common Stage; Jaspert, Politische Öffentlichkeit; Steckel, Professoren in Weltuntergangsstimmung. 
to mobilize further support, and spreading ideas and arguments in texts or dossiers prepared specifically for this purpose, such as dialogues or disputationes, leading to dissemination across existing social networks. ${ }^{113}$ In some cases, new conflict episodes would then be triggered by new rounds of polemics, which constituted a new "occasional public « by openly breaking the established consensus in written form or face-to-face encounter, triggering a next round of controversy in which the opponents were called upon to defend their position. ${ }^{114}$ In contrast to texts produced to mobilize the polemicist's own community, more offensive polemics might either address an opponent directly or appeal to political or legal instances invested with the authority to reopen the debate, such as princes or high-ranking religious figures. The tension between the postulate of a coherent, singular public debate and the multiplicity of local communication networks thus appears ultimately solvable: local communities, supra-local structures of conflict resolution and overarching communication networks linking the parties would all play their part, with specific constellations depending on the degree of mobilization enabled by polemical efforts and local constraints.

Yet the nature of religious polemics also points to a different sort of fragmentation, which the Habermas model of a unified "public sphere" tends to obscure, prompting a third consideration: as the case of Christians and Jews within Latin Europe again underlines, polemics might result in the establishment of separated publics, some of which constituted "subaltern counterpublics «. ${ }^{115}$ That such competing publics confronted each other has been illustrated from various perspectives in the history of Jewish-Christian relations. On the Christian side, polemical discourses contributed significantly to public demonstrations of cultural hegemony within the public space - for example in the use of public images which disparaged Judaism, such as depictions of the "Judensau" on public buildings, ${ }^{116}$ or the desecration of Jewish tombstones which were affixed to Christian houses. Answering Jewish polemics in contrast marked out the spaces and occasions constituting the "counterpublic«, such as the Jewish liturgical poetry disparaging Christianity. ${ }^{117}$ As research on intra-Christian debate culture has recently begun to break away from the Habermas model, this might be another important area for comparative approaches. ${ }^{118}$

113 On the functions of such texts, see, e.g., the observations in Limor, Polemical Varieties; Ragacs, Reconstructing Medieval Christian-Jewish Disputations; Hames, Reconstructing Thirteenth-Century Jewish-Christian Polemic.

114 Cf. Destemberg, Espace public, at n. 14.

115 On this concept, cf. Fraser, Rethinking the Public Sphere, 66-67.

116 See Wiedl, Laughing at the Beast; Scholl, Materielle Hinterlassenschaften als Zeugen.

117 See, e.g., Keil, Orte jüdischer Öffentlichkeit; Yuval, Pessach und Ostern, but cf. also the instances of business documents mentioned by Wiedl's contribution in this volume (at $\mathrm{n} .14$ )

118 See, e.g., Sère, Débats d'opinion; Steckel, Professoren in Weltuntergangsstimmung. 


\section{(4.) Construction of self and other}

Seen from a mid- and long-term perspective, many forms of polemic contributed to the construction and defence of complex cultural identities, usually by drawing on pre-existing traditions, social imaginaires and pluri-medial knowledge archives to contrast a self with an "other « ${ }^{119}$ This characteristic of polemics has important consequences, as it inscribes polemical engagements into pre-existing identity discourses, whose constituent arguments, images, symbols and spaces were appropriated, instrumentalized or polarized. ${ }^{120}$ In the circular pattern of defence and renewed offence characterizing polemical episodes, individual polemicists would draw on established identities anchored in the memories and documents of their communities, but also contribute to the adaptation and continuation of such knowledge archives.

On one side of this cycle, pre-existing religious identities, stored in the collective memory in the form of cultural categories, rhetorical repertoires, texts and images which might be used in polemical engagements, formed a cultural resource for the polemicist, and many polemical discourses were highly tradition-oriented. ${ }^{121}$ Partly, this is simply a result of typical argumentative techniques: in engaging with an opponent, it was an excellent strategy of disparagement to identify or liken the opponent to traditional enemies and religious others, for example to known groups of heretics. To call a thirteenth-century Cathar Good Man a "Manichaean" would not only call up the intellectual arguments which had already been made against the Manichaeans of Antiquity by authorities such as the church father Augustine, suggesting that the opponent was defending a position long dismissed as untenable; it might also activate the emotional and symbolic charges which connected to historical heresies in the collective memory of a thirteenth-century community. If an audience's knowledge about such stereotypical others contained gory details implanted by earlier propaganda, for example the assertion that heretics (or Jews) ritually sacrificed children, even brief references might evoke strong feelings. ${ }^{122}$ The persuasive force of an argument could thus partly be derived from the unspoken elements of an established stereotype, which the addressees would supply by way of memory and association. ${ }^{123}$

In some pragmatic settings, for example in legal courts dealing with many heterogeneous conflicts, other factors such as routinization could contribute to the stereotyping of religious opponents. Grundmann famously demonstrated how the identification of old and new heretics could proceed through practical transfers: ${ }^{124}$ a questionnaire influenced by legal decrees and developed in the interrogation of one heretic might shape the expectations of the interrogators, and from there influence the questions asked of other dissenters, resulting in an assimilation and homogenization of originally heterogeneous instances of dissent

119 On techniques of othering, see the observations of Said, Orientalism, which seem à propos in the study of polemics, but also the overview in Ashcroft, Postcolonial Studies, 154-159; Höfert, Alteritätsdiskurse.

120 See, e.g., Southcombe et. al., Introduction, 6; Przybilski, Beispiele antichristlicher Polemik, 253-255.

121 Van der Wall, Ways of Polemicizing.

122 On the background, see, e.g., the literature mentioned in Rose, Murder of William of Norwich.

123 For an overview of these functions of stereotypes, see, e.g., Schrage, Von Ketzern und Terroristen.

124 Grundmann, Ketzerverhöre des Spätmittelalters als quellenkritisches Problem.

medieval worlds $\bullet$ No. $7 \cdot 2018 \cdot 2-60$ 
into an apparently coherent »sect«. Moore's hypothesis of the "formation of a persecuting society« in Latin Christian Europe during the high Middle Ages makes a similar argument on a grander scale, linking the new scholarly sophistication of legal and theological categorization of religious deviance and impurity developed during the twelfth century to a result of systematized persecution, which led to an assimilation of heretics, Jews, and Muslims, but also lepers. ${ }^{125}$

The influence of tradition is, finally, most strongly felt in cases where polemical elements had time to become absorbed into identity discourses and established themselves firmly in genres usually addressed to a religious ingroup. The stereotypical »Jew of Christian polemical discourses is the best-researched relevant figure. From Late Antiquity onwards, medieval didactic and theoretical genres, such as biblical exegesis, transported images of Jews, heretics and pagans, so that Christian perceptions of Jews were largely determined by the "hermeneutical Jew « (Cohen) constructed by Christian authors. ${ }^{126}$ Such constructions not only distorted the perception of individual Jews, but took on a life of their own, and often served a number of social and political functions. ${ }^{127}$ Several studies have explored the extreme cases of such othering, for example religious polemics which instrumentalized physically absent opponents. Late medieval polemics against Jews in regions like England, Scandinavia, France or Italy, where the Jews had been expelled, created »virtual Jews « ${ }^{128}$, whose image could be drawn upon for various purposes of boundary- and identity making.

If we look towards the different ways in which particular traditions of religious othering were remembered and archived, and how such discourses transformed over time, there is a fairly dense research landscape, but also some gaps, which typically result from issues of diverging chronology, geography or different genres, languages and disciplinary boundaries within research. In the history of Jewish-Christian encounter, for example, there is a fairly clear (if not completely linear) narrative of ongoing deterioration of the mutual relationship. ${ }^{129}$ Research on Islam and Christianity appears to be in the process of revising older narratives. ${ }^{130}$ But the current view on polemical traditions within Latin Christianity is less coherent. The question of longer trajectories has been controversial, with the relative weight of long- and short-term studies coming under detailed scrutiny. The opposing positions have been defended with a focus on persecution: Moore's "Formation of a Persecuting Society" argues for a long-term view on the emergence of religious persecution, but actually considers the long twelfth century with its marked formation of cultural hierarchies as a decisive turning point in its history. Nirenberg's "Communities of Violence", by contrast, insists on

125 Moore, Formation of a Persecuting Society.

126 Cf. Cohen, Living Letters of the Law.

127 On the spread of anti-Judaism across particular societies, see, e.g., Bale, Jew in the Medieval Book; Rubin, Gentile Tales; Hohlstein, Soziale Ausgrenzung im Medium der Predigt; Niesner, Wer mit juden well disputiern. A more systematic argument is made by Nirenberg, Anti-Judaism.

128 See, e.g., Tomasch, Postcolonial Chaucer and the Virtual Jew; Johnson and Blurton, Virtual Jews; further accents in Hess and Adams, Fear and Loathing in the North; Pogossian, Jews in Armenian Apocalyptic Traditions.

129 See, e.g., Chazan, From Anti-Judaism to Anti-Semitism; Cohen, Living Letters of the Law; Abulafia, Jewish-Christian Relations.

130 See generally the literature above, n. 7, especially König, Arabic-Islamic Views. 
the dynamism and differences of local constellations, implying that individual local conflicts might have drawn on similar cultural patterns, but nevertheless remained largely shaped by specific circumstances. ${ }^{131}$ Other studies have fought similar battles over different strands of polemics. ${ }^{132}$ Several authors like Wendy Scase and, recently, Guy Geltner, for example contested Penn Szyittya's earlier hypothesis that there was a fairly homogeneous, century-spanning intellectual tradition of "antifraternalism «, i.e. religious polemic targeting mendicant friars. ${ }^{133}$ Seen from a bird's eye view, these debates mainly illustrate that historical work must draw on combinations of the long- and the short-term approach, and needs to balance both approaches to show how individual events and larger cultural structures affected each other.

Problems arise if this balance is lacking, and research therefore has to fall back on modern master narratives concerning the role of religion in society. In the study of intra-Christian polemics, the influence of such older master narratives and their competing and contradictory historical trajectories is indeed still keenly felt. The most important polemical category structuring the religious field of Latin Christianity, that of heresy, has a long research history even before Grundmann's seminal warnings about stereotyping, but we actually have few long-term studies. Hans-Werner Goetz's reconstruction of the perception of heresy and other religious groups (Paganism, Judaism, Islam and Orthodox Christianity) has recently shown the wealth of material regarding the earlier Middle Ages, which have a tendency to be overshadowed by the "hotspot " high medieval centuries. ${ }^{134}$ Lucy Sackville's study of the thirteenth-century image of heresy in Latin Christianity has also clarified some of the dynamics and consolidation processes that the category of "heresy" was subjected to. ${ }^{135}$ Yet especially for the later Middle Ages, the overall record remains patchy ${ }^{136}$ - even though it seems clear that heresiology is a master discourse on which many other polemical discourses drew. ${ }^{137}$ The perception of heresy not only became entangled in the Latin encounter with Islam and Judaism from the high Middle Ages onwards, but also furnished the elements for several other intra-Christian polemical traditions, among them polemics against reform-resistant clergy ${ }^{138}$ and mendicant friars ${ }^{139}$, and finally the persecution of witches during the later Middle Ages. ${ }^{140}$

131 Moore, Formation of a Persecuting Society; Nirenberg, Communities of Violence. Further discussion, e.g. in Frassetto, Heresy and the Persecuting Society.

132 See, e.g., Frakes, Contextualizing the Muslim Other.

133 See Geltner, Making of Medieval Antifraternalism, and Scase, Piers Plowman, engaging with Szittya, Antifraternal Tradition.

134 Goetz, Die Wahrnehmung anderer Religionen; Aurast and Goetz, Wahrnehmung anderer Religionen im früheren Mittelalter.

135 Sackville, Heresy and Heretics.

136 For a recent panorama, see, e.g., Simpson and Roach, Heresy and the Making of European Culture.

137 On the instrumentalizations of heresy, see recently Mercier and Rosé, Aux marges de l'hérésie.

138 See, e.g., Robinson, Authority and Resistance.

139 See Kerby-Fulton et. al., Pseudo-Hildegardian Prophecy; Steckel, Ein brennendes Feuer in meiner Brust, 152-160. 140 Utz-Tremp, Von der Häresie zur Hexerei. 
Other categories of intra-Christian polemics, especially anti-clerical and anti-monastic discourses, have also been studied for particular periods and regions, but mostly without specific reference to polemics. As a result, there is no clear picture of the trajectories of such critical discourses within Latin Christianity. Studies engaging with these particular strands of Latin Christian polemics often follow specific master narratives revolving around the beginnings of modernity, or rather, modernities: the Protestant Reformation and the many historical narratives organized around $i^{141}$ have provided the most important focus point for the analysis of confessional polemics, and by extension of late medieval anti-clerical, antifraternal and anti-monastic polemics which appeared to be their antecedents. ${ }^{142}$ Studies with a more regional orientation or a focus on vernacular literature often linked anticlericalism and critiques of the religious life to a »Renaissance « narrative, focusing on the emancipation of the laity from ecclesiastical direction (or, in literary terms, the emancipation of the vernacular languages from the Latin tradition). ${ }^{143}$ In firmly separate research fields, we find studies of eleventh- and twelfth-century "polemics of reform " (Thompson) ${ }^{144}$ targeting clerics, or on early controversies among religious orders. ${ }^{145}$ The relevant discourses are at times labelled "polemics", but remain unconnected to research on the later anticlerical traditions - even though there are clear similarities which suggest a common genealogy. ${ }^{146}$ Put together, this research would, in all probability, suggest that we witness a long-term episodic build-up of polemical vocabularies and rhetorics in Latin Christianity, at first primarily in Latin but from the thirteenth century onwards also in the vernaculars and increasingly in formats accessible to popular audiences. However, it remains to be ascertained how different religious conflicts - within the elites of the Latin church, between officials and heterodox movements, and between Christian authorities and Jewish or Islamic interlocutors - shaped this long-term development.

The problem of the geographical spread of different formations of cultural identities has been discussed much more explicitly. Older research tended to make fairly large-scale contentions about cultural differences - for example in arguing that medieval Islam was less invested, and in fact less interested, in confrontation with Christianity than the other way around. More recent studies have argued for a less essentialist approach, and scholars like Daniel König draw attention to the multiplicity of different observers within the ArabicIslamic world, some of whom were highly interested in parts and aspects of Christianity. ${ }^{147}$

141 On the fragmented historiography of the Reformations, see Walsham, Migrations of the Holy, 244-246.

142 See the critical remarks on this tendency in Geltner, Making of Medieval Antifraternalism and cf. e.g. Dykema and Oberman (eds.), Anticlericalism; Goertz, Antiklerikalismus und Reformation.

143 See, e.g., L'anticléricalisme en France méridionale.

144 I borrow this term from Thompson, Polemic of Reform, who nevertheless relates it to the period between the thirteenth and fifteenth centuries.

145 See, e.g., Coleman, Nasty Habits; Pearsall, Medieval Monks and Friars. A research project focusing on satire about monastic life during the fourteenth and fifteenth centuries is ongoing at the Technische Universität Dresden, led by Dr. Kai Hering.

146 If we view the similarities between anti-clerical discourses of the eleventh/twelfth century and later Middle Ages (see, e.g., Robinson, Authority and Resistance and Thompson, Polemic of Reform), genealogical links seem likely. Criticism of the monastic life seems to have a similar trajectory from the tenth and eleventh centuries to the fifteenth century, cf. Steckel, Satirical Depictions of Monastic Life.

147 On this debate, see König, Arabic-Islamic Views, esp. 14-26. 
We also have a number of excellent studies devoted to the culture of polemics developing in particular regions, first and foremost concerning Iberia, ${ }^{148}$ but also other regions like Hungary ${ }^{149}$ or Byzantium. ${ }^{150}$ Other studies have drawn attention to different genres and their perception of religious others. As Almut Höfert argues in her study of Christian views of the Turks during the fifteenth and sixteenth centuries, important shifts can be attributed to the rise of new observer perspectives, such as that of diplomats and of scholars developing an ethnographical rather than heresiological tradition..$^{151}$

As questions regarding the regional and chronological spread of patterns of religious identity and alterity can ultimately only be answered on the basis of comparative studies of larger or smaller remit, recent research has rediscovered an interest in cataloguing polemic, including the availability of various genres of polemic in manuscript form. ${ }^{152}$ Various research projects are currently assembling systematic overviews and databases of polemical corpora - either of certain types of polemics ${ }^{153}$ or of other materials pertinent to the study of religious encounter, such as legal texts on the status of religious minorities collected in the RELMIN project. ${ }^{154}$

\section{(5.) Debatable legitimacy}

If we move towards more scholarly polemical discourses, the modern critical definition of polemics as transgressive argumentation can be included in the list of potential characteristics of polemic. ${ }^{155}$ In an adapted formulation, we may say that polemical engagements could transgress the limits of legitimate argumentation or procedure in a given historical circumstance - and often triggered arguments over such limits.

For the study of medieval polemics, the modern understanding of the polemical as an essentially transgressive argumentation must be problematized - as discussed above, it imposes modern boundaries of legitimacy onto medieval discourses in a highly ahistorical manner, even though medieval polemics were organized by other considerations of legitimacy or transgressiveness than modern ones. Especially in religious polemics, it might, for example, be highly à propos to criticize an opponent with ad hominem arguments, for example in pointing out moral failings which discredited an opponent as hypocritical. To historicize this approach, we would, in essence, have to investigate the historical rules and boundaries of legitimate argumentation for every given polemical situation. Yet such an investigation would, in all probability, only show that historical actors tended to charge each other with transgressions of the legitimate boundaries of debate across all centuries, because they happened to disagree over these boundaries - or even consciously transgressed them to signal

148 See, e.g., Colominas Aparício, Religious Polemics of the Muslims; Herbers and Jaspert, Integration, Segregation, Vertreibung; Nirenberg, Communities of Violence; Nirenberg, Neighboring Faiths; Szpiech, Conversion and Narrative.

149 Berend, At the Gates of Christendom.

150 See the literature above and the contributions in Bonfil et. al., Jews in Byzantium; Tolan et. al., Jews in Early Christian Law; Speer and Steinkrüger, Knotenpunkt Byzanz.

151 Höfert, Den Feind beschreiben.

152 For a small-scale example of such a survey, see Soukup, >Pars Machometica in Early Hussite Polemic.

153 See, e.g., the Repertorium Operum Antihussiticorum, established by Pavel Soukup, www.antihus.eu/about.php (accessed 21.01.2018) or the Islamolatina project conducted by José Martínez Gázquez and others, grupsderecerca. uab.cat/islamolatina/ (accessed 21.01.2018).

154 See www.cn-telma.fr/relmin/index/ (accessed 21.01.2018).

155 See this definition, e.g., in Stauffer, Polemik, 1404; Cancik, Apologetik/Polemik, 33. 
the depth of their conviction.

As it happens, a comprehensive historicization of the cultural regimens governing the practice of historical communities of scholars has been advocated within the cultural history of learning anyway, and many case studies relating to debate culture have been produced. ${ }^{156}$ We can partially reconstruct the unwritten rules regulating various discourses and scholarly practices in circumscribed historical situations, if we acknowledge that such reconstructions describe cultural patterns which consciously abstract from the much messier, contradictory practices of historical actors. Several studies on the »boundary work« undertaken by medieval scholars have also shown that it is quite possible to detect specific short- and mid-term historical dynamics, in which actors attacked particular practices as illegitimate, gradually effecting changes in the rules of engagement dominating specific scholarly milieux. ${ }^{157}$

It is this transformative potential of polemical engagements, and not a postulated metahistorical transgressiveness, which indeed appears as an important characteristic of polemics. As Vincent Azoulay and Patrick Boucheron suggest, the large-scale polemical discourses developing in situations of sustained conflict often led to the formation and distinction of new communities of learning, at times even to the institutional consolidation of new disciplines. As they congenially put it, intellectual violence may appear as "foundational violence", which attacks an opponent, but also sets new boundaries of debate and opens up new areas of contention by force. ${ }^{158}$ Bénédicte Sère has recently developed this observation, pointing out that large-scale controversies in particular must be seen as prime generators of transformation. She therefore suggests an interdisciplinary history of controversies, which analyses practices of conflicts and controversies and the discourses generated by them, and reconstructs the different "polemical regimens" (régimes de polémicite) visible in them. ${ }^{159}$

Taking up the focus on "foundational« intellectual and symbolic violence, Sère highlights a first question to ask of historical polemical regimens, namely how pre-modern controversial discourses were bounded by institutional or situational constraints built on violence - practices of censorship, but also the threat of (judicial or extra-judicial) physical violence, or of exclusion, which made themselves felt in intra-religious as well as in inter-religious conflicts - if, of course, in different ways. ${ }^{160}$ This important nexus represents a prime dimension of inquiry for a history of religious polemics as part of a larger history of controversies.

To distinguish further possible areas of contention in historical debates generating different polemical regimens, it is helpful to analyse the distinction of three different ideal types of polemics suggested by Marcelo Dascal. ${ }^{161}$ Dascal first distinguishes a form of polemics labelled »discussion", in which participants concurred that their disagreement over an issue was based on some form of mistake, and sought for a solution allowing them to correct the mistake, ultimately remaining within a problem-solving framework. The conflict could then

156 For the late medieval and early modern period, see, e.g., Sère, Débats d'opinion; Piron, Écrire en aveugle; Bremer, Religionsstreitigkeiten; Gierl, Pietismus und Aufklärung; for the early and high Middle ages see, e.g., Monagle, Orthodoxy and Controversy; Giraud, Discours magistral.

157 See, e.g., the contributions in Mulsow and Rexroth, Was als wissenschaftlich gelten darf. The concept of »boundary work « elaborated in this volume builds on Gieryn, Boundary-work.

158 Cf. Azoulay and Boucheron, Violences intellectuelles, 31-32 (the reference to "violences fondatrices« on 32).

159 Sère, Introduction. See also Sère, Débats d'opinion, 9-15.

160 See Sère, Débats d'opinion, 13-15 and 351-410. See also her contribution in this volume.

161 Cf. Dascal, On the Uses of Argumentative Reason, 5-7.

medieval worlds $\bullet$ No. $7 \cdot 2018 \cdot 2-60$ 
be ended by a solution found through open-ended engagement. In "disputes", on the other hand, the contenders did not expect conflict resolution through a form of mutually agreed method, as their divergences were rooted in preference, feelings, or belief, and/or shared methods of solution were lacking. A conflict of this type takes the form of contest rather than problem-solving, and cannot be solved, but only »dissolved « by force, avoidance or disregard. In mixed-type "controversies", conflicts escalated to include both debatable issues and diverging beliefs or attitudes. This form of conflict follows a deliberative model and typically finds a "resolution" dependent on the social and political circumstances rather than a solution dependent on the application of a method alone. The contenders are therefore engaged in piling up different sorts of arguments and issues, hoping to "tilt [...] the sbalance of reason in their favour. ${ }^{162}$ Dascal also introduces ideal types of "moves « associated with each form of polemic: the "proof ", which aims to compel the opponent by force of truthful argument; the "stratagem «, which aims to cause or induce belief by overwhelming the opponent (and may even include deceit), and the "argument«, which aims to persuade. ${ }^{163}$

If we attempt to pinpoint the distinctions implicit in this model, at least three analytically distinct characteristics of "polemic" result, which will be separated in the following subheadings. The polarization inherent in polemical discourses may arise because of different views about the best methods for solving the issues at hand. It may also be tied to the circumstances of conflict resolution, arising where participants refuse to engage in open-ended debate, and either enter an argument with pre-determined standpoints or refuse to accept the result of a pre-determined procedure. Polemics may finally also result where opponents simply could not agree on a methodology or procedure for finding the truth, and disparaged each other's methods instead.

\section{(6.) Scholarly methods}

Polemicists could draw on established practices of debate or scholarly methods to elaborate their religious standpoints, or produce specific agreements and compromises regarding such methodologies. Many polemical exchanges take recourse to frameworks and norms established in scholarly settings, and, at times, such settings were negotiated beforehand by the polemical speakers and their opponents. Debates very often led to contestations of the method of discussion and, more importantly, of the textual basis for exchanges, for example in Christian-Jewish disputations of the thirteenth century. ${ }^{164}$

An illustration of the different potential levels of methodological debate can be drawn from a well-known and by now much-debated overview, in which Amos Funkenstein distinguished between four different types (and phases) of Christian anti-Jewish polemic. ${ }^{165}$ In our context, they can be summarized to highlight the pragmatic, factual challenges any scholarly engagement between religious traditions had to overcome. As a first type of anti-Jewish

162 Dascal, On the Uses of Argumentative Reason, 6.

163 Dascal, On the Uses of Argumentative Reason, 6-7.

164 On Jewish-Christian disputations generally, see the contributions in Limor and Stroumsa, Contra Judaeos; Szpiech, Medieval Exegesis and Religious Difference; as well as the literature cited above, notes 7 and 18.

165 Funkenstein, Basic Types of Christian Anti-Jewish Polemic. On the debate sparked by this typology, see, most recently, Berger, Jewish-Christian Debate. 
polemic, Funkenstein lists collections of authoritative citations and arguments culled from biblical and patristic texts, meant to help and support Christian disputants against their Jewish opponents. While this form of engagement largely saw each party drawing on its own scholarly tradition, a second type of polemic instead proposed basing itself on rational, philosophical argumentation, mirroring the shift in scholarly techniques visible in high medieval Europe to establish an (at least superficially) neutral, overarching base for discussion. A third type of Christian polemic attacked the Talmud and other Jewish postbiblical religious literature, crossing linguistic barriers and engaging with issues of text criticism in the process. A fourth type instead drew on the Talmud to attempt to prove that Jewish religious literature supported Christian messages, thus not only engaging with the normative texts of Judaism, but offering competing interpretations of this body of texts instead. Parallel research on other cultural constellations, such as Daniel König's observations on the complex passages visible in Islamic scholars' gathering of knowledge about Latin Christianity, also highlights the many cultural and pragmatic boundaries which had to be crossed in cultural encounters, quite independently of the question of "mental barriers" which might exist against other religions: ${ }^{166}$ Islamic scholars could often not be sure about the quality of information about Christian Europe that they managed to gather. There were multiple linguistic barriers to overcome, and problems of contextualization and interpretations of texts to solve.

Not least for this reason, the positive, culturally productive role of inter-religious polemical engagements and of intra-religious controversies for medieval intellectual exchange has often been emphasized. ${ }^{167}$ Howevermuch religious opponents might disagree, an engagement with competing philosophical and theological systems often forced them to make their own positions more explicit, to refine their methodological and epistemological stance, and at times even to systematize their own handling of authoritative bodies of texts or - especially in the case of inter-religious encounter - to engage in textual criticism concerning sacred or authoritative texts. ${ }^{168}$ Interreligious and intercultural encounter actually often led to a devaluation of the methods and texts used by the opponents, and should not be misunderstood as a typical situation prompting straightforward knowledge exchange. But there is a strong consensus that mutual irritations which prompted different religious scholars to engage with each other's viewpoints were one of the most important drivers of cultural transfer and scholarly innovation during the medieval centuries. ${ }^{169}$ The history of art, which shows closely entangled relationships, for example among Jewish and Christian artists and patrons, bears this out from a different perspective. ${ }^{170}$

166 König, Ausstrahlung - transkulturelle Datenmigration - Dokumentation, at 228; see in more detail idem, ArabicIslamic Views of the Latin West.

167 See recently, e.g., Lasker, Impact of Interreligious Polemic; Freudenthal, Arabic into Hebrew; from a systematic perspective Brentjes et. al., Towards a New Approach. For the role of contacts and conflicts in intra-Christian intellectual life, see Mews, Communautés de savoir.

168 See, e.g., Fidora, Latin Talmud; Ragacs, »Mit Zaum und Zügel«; Lazarus-Yafeh, Intertwined Worlds.

169 This assertion gains importance in the face of recent renewed attempts to appropriate medieval scholarly innovation exclusively for Western, Christian Europe. The case against this isolationist view has been made in the context of the controversy surrounding Sylvain Gouguenheim, cf. Büttgen et. al., Les Grecs, les Arabes et nous. On the dynamics of cultural transfer in inter-religious settings, see recently, e.g., Freidenreich, Beyond Religious Borders; Brentjes et. al., Towards a New Approach to Medieval Cross-Cultural Exchange.

170 See, e.g., Shatzmiller, Cultural Exchange; Kessler and Nirenberg, Judaism and Christian Art. 
As scholars focusing on concepts of religion and religious identities rather than on intellectual exchange have also emphasized, polemical engagements prove to be highly productive triggers for the formulation and explication of religious terminologies. ${ }^{171}$ This discussion has recently gained much ground. During the 1980 s, medievalists still had to rectify the assumption that the Christian Middle Ages had no specific terms for the plurality of "religions «, but tended to view all religious phenomena through an asymmetrical terminology distinguishing "true " Christian "faith " from heresies or superstitions. ${ }^{172}$ In the meantime, a series of publications have pointed out the use of concepts like Latin lex, religio and secta ${ }^{173}$ or Arabic din, which could all be used with or without disparaging connotations. An interdisciplinary study of polemics thus also emerges as a highly promising avenue for exploring medieval religious taxonomies with a view to further interdisciplinary discussion.

\section{(7). Pre-determined stances}

If we look at the patterns of conflict resolution, many polemical engagements - those which conform to Dascal's type of "dispute« or "controversy « rather than that of »discussion ${ }^{174}$ - lack open-endedness. This typically results from a pre-determined stance, as polemical speakers were convinced that they were already possessed of a truth.

This characteristic of polemic can be seen in most medieval inter-religious dialogues and in texts documenting disputations, in spite of their generally dialogic nature. ${ }^{175}$ Participants in inter-faith debates (which were, in any case, often restricted to the discussion of particular factual questions) would usually not treat such disputations as a problem-solving activity, but argued from a position of religious conviction. But at the same time, polemicists typically sought to demonstrate the intellectual superiority of their own faith, and their conviction is thus at times obscured by a strong reluctance to admit prejudice, or at least by the attempt to separate illegitimate prejudice from legitimate confidence in one's own position. Religious disputations were thus intriguing hybrids of intellectual battle and appeals to divine judgement: as in the medieval judicial ordeal, in which God was understood to give the victory to the champion of the deserving side, the discussant had to engage in actual battle while also trusting that truth would prevail. As many studies have pointed out, the representation of scholarly debates in disputation texts actually drew much of its persuasive force from this tension. The narrative arc of intellectual battle (or, in dialogues, of didactic instruction) was used to present highly constrained situations as open-ended discussions, and to assert the victory of one side even where the results of an encounter remained highly contentious. ${ }^{176}$

171 See, e.g., Palumbo, From Constantine the Great to Emperor Wu; Stünkel, Una sit religio; Hasselhoff and Stünkel, Transcending Words.

172 On this debate, conducted from the 1980 s onwards, see Biller, Words and the Medieval Notion of Religion.

173 Besides the literature in note 171, see Weltecke, Religion vor der Religion; Glei and Reichmuth, Religion between Last Judgement, Law and Faith; Tischler, »Lex Mahometi«; Hasselhoff, Huldrych Zwinglis Verständnis von religio.

174 Cf. Dascal, On the Uses of Argumentative Reason, 5-6.

175 On the characteristics of inter-faith and religious disputations, see generally Novikoff, Medieval Culture of Disputation, 172-221; Weijers, Queritur utrum; Limor, Polemical Varieties; Ragacs, Reconstructing Medieval ChristianJewish Disputations.

176 Not only Jewish-Christian disputations but also intra-Christian debates might, therefore, result in several contradictory representations of the outcomes. For an example of the latter, see, e.g., Pietsch, Junge Republik, 271-278. 
If we have no external sources allowing us to reconstruct an instance of controversy, it may be impossible to determine whether a polemicist viewed an engagement as open-ended or brought a pre-determined stance to it. Where such external sources exist, they offer the highly intriguing possibility of tracing the escalation patterns of polemical engagements, which might devolve from open-ended, problem-solving discussions to more complex deliberations and finally to acrid disputes. Yet this distinction forces us to pay close attention to the nuances of polemical argumentation, and to describe transitions from didactic or disputational situations to less regulated conflicts, which would usually overflow the confines of particular institutional settings to address larger publics, and finally to public debates using disparagement as well as scholarly arguments. As will be discussed further in the concluding sections, an interdisciplinary approach to the analysis of patterns of escalation and polemical mobilization therefore seems particularly important.

\section{(8). Epistemological asymmetries}

Polemical engagements frequently produced epistemological asymmetries of some form. Especially in situations in which no pre-agreed method or procedure of truth- or fact-finding existed, polemicists often insisted on the superiority of their own method, procedure or overall epistemological assumptions.

This asymmetry could simply be established in rhetorical gestures or, to use Dascal's term, by way of stratagem. ${ }^{177}$ Southcombe, Suerbaum and Thompson observe how a polemical speaker at times "claim[s] [...] authority to represent the just cause, or (circularly), by articulating unquestionable propositions, establishes authority to speak. ${ }^{178}$ Many references to rational argument used in polemics, for example, turn out to bolster the authority of the speaker, and add little rationality to the argument. David Berger shows this for various references to rational argumentation deployed by high medieval Christian authors against Jewish interlocutors - as these rational arguments often transported known points drawn from authorities, they were essentially "window dressing $"{ }^{179}$ Cédric Giraud observes such symbolic functions of scholarly language among high medieval Christian scholars even outside of inter-religious polemics: the very vocabularies of argumentation current in the high medieval Latin Christian schools often transported implicit assertions of authority. ${ }^{180}$ As Ryan Szpiech points out using the example of the converted Jew Abner of Burgos/Alfonso of Valladolid ( $\dagger$ c. 1345/47), the authorization of a polemical speaker might also gain considerably if he was able to present rhetorical strategies of authorization and authentification which conformed closely to the patterns expected by the audience. ${ }^{181}$

In other cases, polemical speakers elaborated more complex theoretical positions in engaging with religious opponents, explicating their own methodological or epistemological stance. ${ }^{182}$ Though this might (as discussed above) lead to important impulses, many medieval polemicists in fact constructed highly harmful asymmetries. This was largely overlooked by

177 Dascal, On the Uses of Argumentative Reason, 6-7.

178 Southcombe et. al., Introduction, 6.

179 Berger, Jewish-Christian Debate, 126.

180 Giraud, Discours magistral, parole d'autorité; cf. Destemberg, Espace public, at n. 16-19.

181 Cf. Spziech, Conversion and Narrative, 145-154.

182 A popular example is Thomas Aquinas' Summa contra gentiles, see, e.g., Lutz-Bachmann, Rationalität und Religion. 
twentieth-century intellectual historians like Southern, who were happy to celebrate the apparently growing rationality of Christian inter-religious engagement during the twelfth century, and classed it as an instance of the modernity of the medieval West. Anna Sapir Abulafia and others, by contrast, showed how the heightened claims towards rationality uttered by medieval Christian authors also led them to the conclusion that Jews were irrational and, in fact, even obdurate, so that the use of intellectual engagement with them became doubtful. The insistence on human rationality as a way towards faith - which formed an important part of the high medieval humanism fêted by Southern - even led medieval Christian authors like Petrus Venerabilis to doubt the very humanity of Jews. ${ }^{183}$ This construction of a systematically asymmetrical epistemology, which appropriated rationality and scientific principles for Christianity, and skewed theoretical views of the processes of cognition towards the Christian message, thus emerges as a dark underbelly of high medieval rationalism.

\section{Conclusions: Reconstructing patterns of embedding and escalation of polemics across cultures and genres}

So far, this article has surveyed some of the different accentuations given to the concept of religious polemics in different research traditions, and has suggested a preliminary breakdown of various constituents or dimensions of polemical discourses. Given the extreme complexity of the topic and the very broad range of different phenomena assembled under the umbrella term of "polemics", one may well pause briefly to ask whether any further clarification and operationalization will actually be useful. Couldn't we simply avoid the term and start afresh with studies on »invectivity« or »hate speech» on one side, and »(inter-)religious encounter" on the other?

In answer to this rhetorical question, one may state that terminological distinction is certainly one pragmatic strategy to counter the ambiguities and complexities of the term "polemics". Scholars studying inter-religious debates may prefer to speak of religious controversies (understanding that these may, under their respective polemical regimens, include elements of disparagement or violence) or of the construction of religious difference and diversity. Scholars interested in forms of disparagement of other religious groups may be better off with an exclusive focus on different historical forms of aggressive rhetoric, or "invectivity", or even take up the contemporary label of "hate speech". These two research themes - of religious controversy with its polemical regimens and of invectivity - indeed appear as the two main centres of gravity within the interdisciplinary research field. Both offer themselves for further comparative research, especially for transcultural comparisons, which juxtapose culturally separate but similar phenomena in order to refine our view on them and tease out the different cultural nuances. ${ }^{184}$ Pursuing such broadly comparative perspectives indeed appears in order if we hope to push the interdisciplinary boundaries further out and include a (geographically and chronologically) broader range of different historical polemics.

183 Cf. Abulafia, Christians and Jews in the Twelfth-Century Renaissance; eadem, Christians and Jews. 184 Höfert, Europa und der Nahe Osten. 
Yet something would be lost if we focused only on scholarly polemics, or only on invectives, or only on inter-religious encounter, and three research fields which encourage a broad approach to polemical traditions in all of their variety can be described with a little more clarity at this point. In these concluding observations, the contributions making up the thematic section in this volume, which ask particularly how texts or situations "verged on the polemical « within the Latin Christian tradition, will be used to furnish some examples. ${ }^{185}$

Firstly, the study of religious polemics continues to be of interest as part of a "cultural history of controversy «, as Jean-Pascal Gay and Bénédicte Sère put it. ${ }^{186}$ The investigation of polemics is a particular form of the study of conflict, which has long proved to be one of the most privileged and fruitful methodological perspectives available within the theoretical framework of cultural history. The modern term »religious polemics" actually puts the spotlight on a highly charged communicative interface between different societal spheres: in investigating religious polemics, we ask how religious identities - and thus cultural hierarchies - were imagined and expressed, either in a given moment or over longer periods. But at the same time, we ask about the categories of description and the techniques of rhetorical persuasion employed by polemicists to convince different audiences of their stance, and about the relations they postulated between religious truths and the intellectual methods of explicating them - and at times also between religious truths and economic, political, or legal norms.

Where the sources allow us to draw these threads together, the study of religious polemics offers an intriguing point of historical observation, which allows us to reconstruct mid- and long-term transformations resulting from culturally productive tensions. One such tension exists between polemical writings and philosophy, theology, and political theory: ${ }^{187}$ As Bénédicte Sère's contribution in this volume shows, for example, large-scale debates like the one rocking the Latin church during the Great Western Schism (1378-1417) could lead to very distinct renegotiations of the reach of intellectual analysis in solving the problems of political hierarchy. In negotiations determining whether scholars were allowed to debate the limits of papal power, and in power politics which established intellectual or physical constraints on the activity of scholars, such controversies realigned the relationship of scholarly expertise, religious authority and political power to produce new cultural constellations, which were, in turn, mirrored in changing polemical regimens.

A second area of investigation concerns the spread of polemical discourses within specific historical societies. As stated in the introduction, we know that the term "polemics" encompasses a whole range of textual and visual genres ranging from the most elaborate scholarly engagements to the coarsest disparagements, and we know that we often find elements of polemical argumentation embedded in texts or images not primarily aiming at religious confrontation. Yet we have no clear, cross-disciplinary typology of such semi-polemical forms, and no clear terminology for studying the way polemical traditions permeated medieval societies.

185 It should be noted that these contributions are used to make particular points and cannot be summarised in full. 186 Cf. Gay, Lettres de controverse; Sère, Introduction, at n. 1.

187 See, e.g., Lasker, Impact of Interreligious Polemic, 122. For the Christian area, see, e.g., the observations by Marmursztejn, Autorité des maîtres. 
One strategy for exploring the range of different text types which may contain polemical elements is to follow up the textual (or visual) reception of polemical traditions, and to study the way different genres and their pertinent rhetoric intermingled. Reima Välimäki's article in this volume illustrates the spread of specialized polemical material into more popular didactic genres on the fundamental level of materiality and linguistic transmission: he discusses how a Latin polemical text dealing with heretical Waldensians, Petrus Zwicker's Cum dormirent homines (1395), was translated into the vernacular (Early New High German) and subsumed in all its parts into a catechetical encyclopedia aimed at laypeople by Ulrich von Pottenstein ( $\dagger$ 1417) about fifteen years later. As Välimäki highlights, this process of translation also led to changes. Often, these were explications and clarifications of aspects which remained largely implicit in the Latin original. But Pottenstein also added some emphases - for example in attacking bad clerics, whose faults contributed to the heretics' success. The inclusion of all parts of an anti-heretical treatise into an essentially didactic text, which fits into the well-known fifteenth-century tendency of providing more elaborate theological education for the laypeople, ${ }^{188}$ is also intriguing. As Välimäki points out, we do not know enough about the relationship between polemical and catechetical texts for the later Christian Middle Ages, nor probably for other cultures.

In Justine Trombley's contribution, we find another instance of polemical elements becoming embedded in other genres, though this time, the direction is reversed: her analysis engages with the "Mirror of Simple Souls", a work authored by the beguine and mystic Marguerite Porete, which continued to circulate anonymously after Marguerite had been burned at the stake at Paris in 1310. As Trombley shows, there were rather different strategies for refuting this text. While some extant refutations remained completely within the framework of scholarly techniques of identification of errors, simply listing articuli containing errors and the authorities necessary to refute them, one treatment engages rhetorically with the anonymous work. Moreover, as Trombley points out, this narrative attack on the "Mirror" made use of a whole repertoire of different rhetorical strategies, drawing on different anti-heretical traditions using arguments and authorities, but also disparaging categories and highly emotional rhetorical appeals. Though the exact background of this anonymous attack must remain unclear, the text throws up many questions about authorial intentions, possible audiences, and typical patterns of polemical rhetoric in its day: was the author experimenting with different styles - or perhaps embedding a different rhetorical pattern of polemical engagement, such as sermon rhetoric, into a text originally meant as a theological refutation or consilium? A comparative approach might furnish a much better framework for making such judgments, and for refining the distinctions underlying them.

Better knowledge about the diffusion of polemic would also provide a better basis for other comparative questions, for example concerning patterns of escalation in religious conflict. In this instance, differences between inter-religious and intra-religious conflicts play a significant role. Between faith communities like Jews, Muslims and Christians, religious difference was already established, while various intra-Jewish, intra-Islamic or intra-Christian conflicts needed to construct this difference in the course of conflict escalation. Melanie Brunner's contribution in this volume provides the rare example of an intra-religious conflict escalation beginning almost from scratch, reconstructing the rhetoric accompanying 
the split of the religious order of the Friars Minor or Franciscans into the factions of the radical so-called Spiritual Franciscans and the Community around 1300. As Brunner shows, this conflict created polarizing argumentative schemes of "good" and »bad" Franciscans, contributing to the development of diverging religious identities within the Order. But the treatises also linked the difference of the respective »bad « side to the concept of heresy, making use of established repertoires of anti-heretical argumentations and disparaging rhetoric, for example in calling their opponents heretics and hypocrites.

Several interesting functions of this inscription of the debate into a pre-existing polemical tradition stand out: we may note that the ascription of heresy seems to have a signalling function in a conflict which was in the process of shifting from the clearly defined decisionmaking structures of the Franciscan order into a broader public, consisting of the order's friars but also political and legal decision-makers, now addressed by the competing argumentative treatises hoping to sway their opinion. Read closely, even the driest polemical arguments therefore not only made legal points, but also worked on a level of symbolic communication appropriate to this public space, much like the physical gestures which would have accompanied trajectories of escalation or breakdowns of communication in a face-to-face conflict in the political sphere. ${ }^{189}$ Warning the opponents that they were falling into heresy was not only a legal argument, but amounted to the rhetorical drawing of a line in the sand, marking particular contentious points and signalling the speaker's refusal to compromise. It might, therefore, be interesting to ask how far such polemical rhetoric may be correlated to patterns of public debate common in political sphere. Other Franciscan borrowings from older polemical discourses actually show that the polemical escalation drew on a whole underlying taxonomy of religion, which formed the basis for relational ascriptions of religious difference. As the Franciscans were deeply engaged with the church's battle against heresy, accusing them of heretical behaviour - and thus linking them to their most particular symbolic "other" - also implied that they had not only violated, but inverted the value hierarchy upon which the order was predicated.

In polemical rhetoric formulated by Christians against Jews or vice versa, such relational argumentation may also be present, as will become clear in a moment. But it seems obvious that much Christian polemic against Jews uses different techniques of escalation - mainly because religious difference was already established, but also because the relevant polemical discourses belonged in different contexts and spoke to different audiences. Birgit Wiedl's contribution on the amical relations and polemical engagements with Jews visible in Christian business documents presents us with highly interesting findings in this respect. Business documents like charters are intriguing cultural interfaces which illustrate the closely entwined social worlds of Christians and Jews. As Wiedl shows, many of them document close contacts and respectful alliances. Yet occasionally they contain polemical attacks, and at times allow us to draw conclusions about the deep-seated suspicions which Christians harboured against their Jewish business partners, and which Christians embroiled in business conflicts might attempt to instrumentalize. Wiedl's cases clearly document how the presence of a pre-existent, broadly established polemical discourse against Jews made it possible for such Christian authors to generate resentment and sway their audiences with minimal rhetorical effort, as they could rely on their Christian interlocutor's collective memory to supply negative associations. In one law case we thus find a complaint among neighbours 
concerning noise and smell referring to a »Jewish stench «. This clearly sought to trigger a physical reaction of disgust and anger. Similarly, an ecclesiastic lamented about being caught in an "abyss of usury " by his Jewish creditors. Even though the debts in question were incurred in completely legal circumstances, this reference to usury, linked by association to injustice and transgression of moral norms, could apparently be relied on to mobilize other ecclesiastics to come to his aid.

Claudia Daiber's contribution on the fifteenth-century anti-Jewish Fastnachtspiel »Von dem Herzogen von Burgund « makes the other, missing half of such polemical strategies visible: the religious drama analysed in her article literally seems to try to put the full repertoire of anti-Judaist and anti-Semitic theories, stereotypes, and rhetoric onto the public stage, providing the Christian community with an emotionally charged rehearsal and a boiled-down theological legitimation of the negative stereotypes against Jews, laying the groundwork for brief evocations of resentment such as the ones encountered by Wiedl. Though we know nothing about the circumstances which might have accompanied such a staging, the play authored by the layman Hans Folz († 1513) again illustrates how elements of anti-Jewish polemics might be transformed by their translation into the vernacular, and in this case, also into the popular format of a Shrovetide play. The play pulled out all the stops to make a tangible, emotional, and fully lived reality out of the theological arguments and literary tropes concerning Jews. It included a staging of the allegedly evil, grasping nature of the Jews who were shown to physically crowd and threaten the Christians on the stage, a coarse, humorous rendition of the false Jewish Messias, and a live appearance of the iconic Judensau. As Folz's social contacts tie him to the Nuremberg business elite, who were highly interested in removing the competition constituted by the Jewish communities, we again glimpse the mutual instrumentalization of religious difference and business interests already emphasized by Wiedl.

The contrast between this situation and the polemics exchanged between the factions of the Franciscan order seems marked, and it would indeed be highly problematic to subject such different forms of religious encounter to a schematic comparison. The long-term relations between Christians and Jews, who lived in the midst of Christians in a highly precarious position, and accumulated a complex tradition of polemics as their paradigmatic religious other over the centuries, must, of course, be seen as one of a kind. Yet there are comparative questions that allow us to sharpen our heuristic tools, and may, therefore, still be asked. Returning to the intra-religious conflicts surrounding the religious order of the Franciscans, we might, for example, ask whether the polemics exchanged by and about them could not also draw on well-established discourses already present within the collective memory. In some respects and to a limited degree, this seems to be the case. One notable feature of the exchanges between the Spiritual and the Community Franciscans for example consists in the accusation of hypocrisy. On one side, this was another highly traditional disparagement, borrowed from well-established anti-heretical rhetoric, which had been distributed by the preaching of the Franciscans and of other mendicant orders since the early thirteenth century. ${ }^{190}$ But, more than this, the accusation of hypocrisy was also a prime charge laid against the Franciscans (and other mendicant orders) by their long-term rivals and competitors, the secular clergy, who had been involved in public, at times highly aggressive controversies with the Franciscans for decades, and had borrowed the charge of hypocrisy from anti-heretical 
polemic to construct a new polemical strand of anti-mendicant or anti-fraternal polemic. ${ }^{191}$ If some Franciscans now joined these arch-competitors in calling some of their brothers hypocrites, this implied not only that these brothers had betrayed their order by conforming to the outsider's worst expectations; it also signalled that the accusing group was ready to side with the order's enemies to incriminate the deviants.

This is not only another instance of a relational construction of difference. The accusation of hypocrisy was also perhaps the most relevant element of the thirteenth-century controversies between secular clergy and mendicant orders which had entered vernacular discourses, for example in political poetry and in the sophisticated but popular Roman de la Rose of the 1280 s, which embodied hypocrisy in the allegorical figure of "False Seeming", a sly trickster who took on various religious habits. ${ }^{192}$ While the references to hypocrisy in the polemics between Spiritual Franciscans and Community may only have the most tenuous links to this discourse, it was highly present in other polemical engagements between the mendicant orders of the Dominicans and Franciscans, the laypeople and the clergy during the thirteenth, fourteenth and fifteenth centuries. ${ }^{193}$ Spread through a combination of theological polemics against hypocritical friars, monks, nuns or clergy, and of literary texts and stories diffusing these arguments together with adjacent stereotypes and typical complaints in the vernacular, this discourse enabled brief and evocative polemical argumentations, similar to those visible in Wiedl's anti-Jewish outbreaks in business texts. In the decades around 1300, for example, we encounter several instances of popular protest and even some instances of (comparatively circumscribed) violence against friars, which broke out when participants in legal conflicts, primarily inquisition trials, managed to mobilize popular feeling against the mendicant inquisitors by polemicizing against them, stressing conventional anti-clerical and anti-mendicant tropes of religious hypocrisy, greed for money, and sexual transgression. ${ }^{194}$

Altogether, the complex Jewish-Christian relations and the tangled strands of intraChristian polemical discourses might thus furnish interesting comparative horizons for each other - but to develop this perspective, we would first have to overcome the fragmentation of different research fields, and then to investigate the connections between different strands of Christian anti-heretical, anti-clerical, anti-monastic and anti-fraternal polemics.

In a next step, such an integrated, comparative perspective could be developed further by also investigating the links between intra-religious and inter-religious polemics - a third research field which awaits a more systematic exploration. A first, general question which has not been asked systematically concerns the differences between intra-Christian polemical discourses (including anti-heretical polemics) and inter-religious polemics. As extant research suggests, they were different - but there were a number of identical or closely linked arguments, images, and stereotypes, as most polemical discourses within Christianity sooner or later became entangled through transfers and adaptations of particular arguments or rhetorical and artistic styles. This highlights the problems we create when we apply the modern concept of "religion" to the pre-modern period: within medieval societies, people did not encounter Jews, Christians, Muslims, heretics, bad clerics, or simply impious people separately and without linking them. On the contrary - especially in making polemical remarks

191 Cf. Geltner, Making of Medieval Antifraternalism; Steckel, Falsche Heilige.

192 See Emmerson and Herzman, Apocalyptic Age of Hypocrisy, and cf. Huot, Romance of the Rose.

193 See, e.g., Bruschi, Falsembiante-Inquisitor; Scase, Piers Plowman; Geltner, Making of Medieval Antifraternalism. 194 The paradigmatic case of Bologna 1299 is described in Thompson, Lay Versus Clerical Perceptions of Heresy. 
about representatives of different groups, they frequently created overarching taxonomies of religion and linked these to criteria of good or bad religiosity, creating a practical, messy, and highly heterogeneous discourse on "religion". If we aim for further clarifications of the conceptualization of »religion « and religious diversity during the medieval centuries, and if we hope to reconstruct how religious difference was discussed within different social groups and media, this practical, polemical discourse concerning religion appears highly relevant.

To investigate this discourse fully, however, we need to cut across the boundaries of the research fields of religious encounter on one side, and intra-religious dynamics on the other, and ask how the medieval discourses concerning the relevant entities were linked. In practice, we might, for example, ask how intra-religious conflicts made use of inter-religious polemics - for example in polemical comparisons which linked members of one one's own group to various religious others.

Especially if we count "heresy « as a separate religious group, this technique is surprisingly widespread within Latin polemics. We not only encounter Franciscans calling their errant brethren heretics, but a whole spectrum of different forms of polemical comparisons and identifications which linked different religious groups and thus implicitly constructed religious taxonomies.

Andra Alexiu's contribution to this volume, on Hildegard of Bingen as a polemicist against "false teaching ", shows several variants of comparison as a polemical technique. Hildegard's text (in letter form, but based on a sermon) constructed a complex landscape of religious difference by way of different comparative operations. Hildegard's admonition contains some outright comparisons linking her addressee, the lax Christian clergy of Cologne, to different religious others: the ideals of the biblical past, some negatively connotated biblical groups such as the Sadducees, as well as the unavoidable animals (here scorpions). But Hildegard also built a relational argument on a large-scale comparison of clerics and (Cathar) heretics, ultimately in a manner similar to the Franciscan polemics analysed by Brunner. On one side of a double juxtaposition, Hildegard confronted the bad teaching of the lax, morally compromised clergy of Cologne with biblical examples of good teaching and her own role as a "teacher of teachers". On the other side, she introduced the threatening image of present and future groups of heretical "false teachers « descending on the town with the intent of corrupting the laity, particularly the women, and supplanting the clergy. A long comparative passage then points out the differences in behaviour between clergy and heretics: the false teachers are supported by the devil and possess evil supernatural powers, providing them with the strength enabling a strict ascetic life and absolute chastity. The current, underperforming pastors, by contrast, fall into moral corruption, allowing themselves to be surpassed by the heretics. The moral order is thus completely reversed, putting the church in grave danger.

In this text, a multi-way taxonomy of religious groups becomes visible, which ranges from the biblical Sadducees via two different groups of heretics (the present-day Cathars and a future group of "hypocrites « announced as harbingers of the Antichrist) to the present clergy, subdivided into laudable and corrupt. As Alexiu emphasizes, Hildegard's prophetic voice, presenting itself as an authority figure located on a meta-level, also manages to position itself at the top of the proposed hierarchy.

As in the Franciscan polemics discussed by Brunner, the primary polemical comparison that of clerics/Franciscans with heretics - creates its effect by linking the religious ingroup to the outgroup, and inverting the usual hierarchy. Bad clerics were not just violating norms, but subverted the cultural hierarchy by falling below the moral standard of heretics and thus 
transgressing the very boundaries of Christianity. Similar effects could be generated by other comparisons: Christian reformers engaging in hostilities with high medieval heretics at times likened them to Jews. ${ }^{195}$ Critics of the monastic orders, such as the Welsh cleric and courtier Walter Map († c. 1210), who engaged in a series of conflicts with the reformed monastic order of the Cistercians, also compared them to Jews. ${ }^{196}$ The comparison with Judaism was later enlarged by Martin Luther to encompass and disqualify the whole lifeform of regulated, monastic or mendicant orders. ${ }^{197}$ Both Judaism and Islam furnished polemical comparisons in debates between secular clerics and mendicant friars. ${ }^{198}$ In the conflict between the supporters and opponents of the reformer Jan Hus ( $\dagger$ 1415) in fifteenth-century Bohemia, the conflict party supporting the papal side was disparaged as the "Muslim party $«{ }^{199}$ Yet so far, we only have tentative and small-scale investigations of such comparisons - even though they seem surprisingly widespread, for example in didactic genres, which at times contain admonitory comparisons of bad Christians to Jews, Muslims or heretics. ${ }^{200}$

Such isolated polemical passages are typically not at the centre of attention in the study of polemics. Often, they are brief, almost throwaway references, which convey nothing new. But if we hope to understand the way polemical discourses became embedded in society, they nevertheless form an intriguing subject. While such comparisons could, of course, easily be explained away as stereotyped instances of othering, which have little to say, several cases imply that the relevant comparisons, albeit highly polemical, nevertheless constitute religious comparisons, and thus form part of the emergence of overarching evaluative discourses on religion and religious diversity.

Though such polemical comparisons do not use the scholarly, ethnographic or heresiological lens usually studied by scholars interested in comparative religion (a fact which typically leads to their omission in the specialized study of religious comparisons ${ }^{201}$ ), they nevertheless document how medieval authors linked different religions. ${ }^{202}$ Though stereotyped, such polemical attacks often resulted from very tangible dynamics of religious pluralization, as Hildegard's polemical juxtaposition of lax clergy and morally superior heretics illustrates. The heterodox groups which so threatened the high medieval church often, indeed, represented a better version of the clergy, and laypeople were highly interested in comparing them. It might thus be worthwhile to ask in a comparative perspective where and how these and other forms of polemical comparisons occurred, what polemical contexts we find them in, and what they can tell us about medieval perceptions of religious diversity and religious hierarchies.

195 Cf. Berger, Christian Heresy and Jewish Polemic, 210.

196 Cf. Walter Map, De Nugis Curialium, ed. James et al., d. 1, c. 25, 85-113 (comparing the Cistercians to the biblical Hebrews, but with polemical overtones pointing towards contemporary Jews).

197 Stamm, Luthers Stellung zum Ordensleben, 114-118, esp. n. 46.

198 See, e.g., the sermon documented in Bataillon, Intervention maladroite, and the implicit comparison in Henry of Ghent, Quodlibet XV, ed. Etzkorn and Wilson, 147-154, at 152-153. I am currently preparing a study of both texts. 199 Cf. Soukup, 'Pars Machometica in Early Hussite Polemics.

200 For an example, see, e.g., Von Karajan, Buch der Rügen, with polemical comparisons at 46 (1l. 28-37, Jews and Pagans) and 64 (ll. 659-665, Jews).

201 For this view of medieval polemical comparisons cf. Von Stuckrad, Religionsvergleich. 202 On this aspect of polemical comparison, see the remarks by Cavarzere, A Comparative Method. 
Intriguingly, we also find parallel polemical strategies in other cultural traditions, so that a transculturally comparative perspective is an option. Both Jewish and, presumably also, Islamic polemicists at times attacked Jewish or Islamic opponents by comparing them to Christians, heretics or unbelievers. ${ }^{203}$ In a responsum concerning the dissolvability of a marriage involving an ill woman, for example, the famed Jewish scholar Rashi († 1105) judged that it was not merciful to cast out a marriage partner who was ill, especially in the particular case in question, concerning a woman who only had a small rash. As Rashi added, the man attempting to get rid of her showed himself to be "not of the seed of our father Abraham", as he fell below a standard of merciful behaviour even upheld by those who denied God, i.e. the Christians. ${ }^{204}$

Just like Hildegard's unfavourable comparison of the lax clergy with pious heretics, this brief remark suggests a cultural horizon in which different religious behaviours were highly comparable. As there was room for genuine debate concerning divorce and illness in Christian legal norms concerning leprosy, ${ }^{205}$ one even wonders whether Rashi's offhand remark indicates that he was observing an actual Christian debate from a distance. In any case, Jewish polemicists usually constructed a sense of superiority by commenting on the lax morals of Christians ${ }^{206}$ - but as Rashi's responsum shows, the implicit hierarchy which demanded that Jews should surpass Christians could also be inverted to admonish co-religionists.

The investigation of such polemical comparisons in a connected and comparative perspective, looking both for transfers, influences and parallel occurrences of similar phenomena, might not only explore one technique of polemical rhetoric. The study of comparisons, a fundamental cultural practice of establishing identity, difference, and hierarchy, might also tell us something about the way medieval people connected, compared and ordered different forms of religiosity. As both Hildegard's and Rashi's comparisons show, moreover, such polemical comparisons actually debated issues, such as the chastity and moral life of the clergy, or the handling of illness, and were not just confrontations between one religious group and an incriminated, devalued other. The presence of three-way constellations - good Jews, bad Jews and Christians, or good clerics, bad clerics and heretics - gives us a stronger sense of the importance of the tertia comparationis of the underlying debates.

In conclusion, it is to be hoped that the exemplary questions and perspectives discussed in this last section can show that there is still much to be gained by bringing new impulses to the long-standing traditions of research on religious polemics. The necessarily narrow focus of this contribution, which clearly betrays its author's central interest in Latin Christianity, may even, rather inadvertently, have uncovered something of a gap in research: while scholars investigating religious encounter within the Mediterranean world have forged ahead and created an interdisciplinary research field focused on the contacts and polemical confrontations between Jews, Christians and Muslims, the study of polemics among the

203 Excepting research on the application of the heresy/unbelief label (see notes 13-16 above), literature dealing specifically with polemical comparisons within Judaism and Islam seems scarce.

204 I would like to thank Professor Regina Grundmann for pointing this reference out to me. I use the German translation in Von Mutius, Rechtsentscheide Raschis von Troyes, at 2:130-131 (quotation of German translation: "nicht vom Samen unseres Vaters Abraham«, 130).

205 See, e.g., Miller and Nesbitt, Walking Corpses, 106-110.

206 See, e.g., Berger, Introduction, 96-99. 
multi-centred world and highly diverse religious elites of Latin Christianity hasn't been able to keep up completely. The central Middle Ages may have drawn substantial interest, and extant research has pointed out some of the most important dynamics of cultural entanglement between concepts of heresy, Islam, Judaism and religious orders, but many nodes and twists of the tangled strands of polemics between heterodox and orthodox Christians, good and bad monks and clerics, and their similarities to Jews, Muslims or Pagans still remain to be explored.

Engaging with this research field of intra-Christian diversity might also, moreover, give added impulses to a global perspective on religious polemics. As Antonello Palumbo recently pointed out, we do not only observe encounters between different religions and forms of religiosity in pre-modern Asia. Rather, we find constellations in which polemical discourses between faith communities (such as Buddhism, Taoism and folk religion practices) intersected with internal dissensions within these communities. ${ }^{207}$ Developing a holistic approach to such constellations of religious diversity, which includes both inter-religious and intrareligious polemical discourses, might thus actually give fresh impulses to several of the fields involved. Ultimately, developing a comparative and connected perspective, even just on those regions we already feel familiar with, would not only contribute to the study of religious polemics, but also furnish important materials to an emerging global history of forms of religious diversity.

\section{Acknowledgements}

This research was undertaken within the framework of the Dilthey Fellowship research project "Diversitas religionum. Thirteenth-century foundations of European discourses of religious diversity«, supported by a joint initiative by the Volkswagen Stiftung and the Fritz Thyssen Stiftung. 


\section{References}

\section{Primary sources}

Bernard Gui, Practica inquisitionis heretice pravitatis, ed. Célestin Douais (Paris, 1886).

Henry of Ghent, Henrici de Gandavo Quodlibet XV, ed. Girard Etzkorn and Gordon A. Wilson, Ancient and Medieval Philosophy Series II 20 (Leuven, 2007).

Jan Hus, Magistri Iohannis Hus Polemica, ed. Jaroslav Eršil, Gabriel Silagi and František Šmahel, Opera Omnia 22 (Turnhout, 2010).

Walter Map, De Nugis Curialium - Courtiers'Trifles, ed. Montague Rhodes James, Christopher Nugent Lawrence Brooke and Roger Aubrey Baskerville Mynors, Oxford Medieval Texts (Oxford, 1983).

Secondary literature

Abulafia, Anna Sapir, Christians and Jews in Dispute: Disputational Literature and the Rise of Anti-Judaism in the West (c. 1000-1150) (Aldershot, 1998).

Abulafia, Anna Sapir (ed.), Religious Violence Between Christians and Jews: Medieval Roots, Modern Perspectives (Basingstoke, 2001).

Abulafia, Anna Sapir, Christian Jewish Relations 1000-1300: Jews in the Service of Medieval Christendom, The Medieval World (London, 2012).

Adang, Camilla, Anșārī, Hasan, Fierro, Maribel, and Schmidtke, Sabine (eds.), Accusations of Unbelief in Islam: A Diachronic Perspective on Takfir, Islamic History and Civilization. Studies and Texts 123 (Leiden, 2016).

Adang, Camilla. Hypocrites and Hypocrisy, in: Jane D. McAuliffe (ed.), Encyclopedia of the Qur'an, vol. 2 (Leiden, 2002) 468-472.

Althoff, Gerd, Gefühle in der öffentlichen Kommunikation des Mittelalters, in: Claudia Benthien, Anne Fleig, and Ingrid Kasten (ed.), Emotionalität: Zur Geschichte der Gefühle, Literatur, Kultur, Geschlecht 16 (Cologne, 2000) 82-99.

Altschul, Nadia R., Postcolonialism and the Study of the Middle Ages, History Compass 6/2 (2008) 588-606.

Ames, Christine Caldwell, Medieval Heresies: Christianity, Judaism, and Islam, Cambridge Medieval Textbooks (Cambridge, 2015).

Amit, Yaira, Hidden Polemics in Biblical Narrative, Biblical Interpretation Series 25 (Leiden, 2000).

Anheim, Étienne, L’humanisme est-il un polémisme ? À propos de Invectives de Pétrarque, in: Vincent Azoulay and Patrick Boucheron (eds.), Le mot qui tue: une histoire des violences intellectuelles de l'Antiquité à nos jours, Epoques (Seyssel, 2009) 116-129.

Ash, Mitchell G., Wissenschaft(en) und Öffentlichkeit(en) als Ressourcen füreinander, in: Sybilla Nikolow and Arne Schirrmacher (eds.), Wissenschaft und Öffentlichkeit als Ressourcen füreinander: Studien zur Wissenschaftsgeschichte im 20. Jahrhundert (Frankfurt/ Main, 2007) 349-362.

Ashcroft, Bill, Gareth Griffiths, Helen Tiffin, Post-Colonial Studies: The Key Concepts (second edition) (London, 2009).

Aurast, Anna, and Goetz, Hans-Werner (eds.), Die Wahrnehmung anderer Religionen im früheren Mittelalter: terminologische Probleme und methodische Ansätze, Hamburger Geisteswissenschaftliche Studien zu Religion und Gesellschaft 1 (Münster, 2012). 
Azoulay, Vincent and Boucheron, Patrick (eds.), Le mot qui tue: une histoire des violences intellectuelles de l'Antiquité à nos jours, Epoques (Seyssel, 2009).

Azoulay, Vincent and Boucheron, Patrick, Les violences intellectuelles, nouvel objet d'histoire, in: Azoulay, Vincent and Boucheron, Patrick (eds.), Le mot qui tue: une histoire des violences intellectuelles de l'Antiquité à nos jours, Epoques (Seyssel, 2009) 23-52.

Bale, Anthony Paul, The Jew in the Medieval Book: English Antisemitisms, 1350-150o, Cambridge Studies in Medieval Literature (Cambridge, 2006).

Barton, Carlin A., and Daniel Boyarin (eds.), Imagine No Religion: How Modern Abstractions Hide Ancient Realities (New York, 2016).

Baskind, James, Christian-Buddhist Polemics in Late Medieval/Early Modern Japan, Religion Compass 8/2 (2014) 37-48.

Baumann, Uwe, Becker, Arnold, and Laureys, Marc (eds.), Polemik im Dialog des RenaissanceHumanismus: Formen, Entwicklungen und Funktionen, Super alta perennis 19 (Göttingen, 2015).

Baumgarten, Elisheva, and Galinsky, Karl (eds.), Jews and Christians in Thirteenth-Century France, The New Middle Ages (New York, 2015).

Baumgarten, Elisheva, Mazo Karras, Ruth, and Mesler, Katelyn (eds.), Entangled Histories: Knowledge, Authority, and Jewish Culture in the Thirteenth Century, Jewish Culture and Contexts. (Philadelphia, 2017).

Bataillon, Louis Jacques, Une intervention maladroite de Pierre de Tarentaise en faveur des mendiants, in: Thomas Prügl and Marianne Schlosser (eds.), Kirchenbild und Spiritualität. Dominikanische Beiträge zur Ekklesiologie und zum kirchlichen Leben im Mittelalter. Festschrift für Ulrich Horst OP zum 75. Geburtstag (Paderborn, 2007) 143-177.

Bechmann, Ulrike, Prenner, Karl, and Renhart, Erich (eds.), Der Islam im kulturellen Gedächtnis des Abendlandes (Graz, 2014).

Beck, Hans-Georg, Kirche und theologische Literatur im byzantinischen Reich, 2 vols. (Munich, 1959).

Becker, Adam H., and Yoshiko Reed, Annette, The Ways That Never Parted:Jews and Christians in Late Antiquity and the Early Middle Ages (Tübingen, 2003).

Berend, Nora, At the Gate of Christendom: Jews, Muslims, and "Pagans" in Medieval Hungary, $c$. 1000-c. 1300, Cambridge Studies in Medieval Life and Thought (Cambridge, 2001).

Berger, David, Christian Heresy and Jewish Polemic in the Twelfth and Thirteenth Centuries, in: David Berger, Persecution, Polemic and Dialogue. Essays in Jewish-Christian Relations, Judaims and Jewish Life (Boston, 2010) 209-226.

Berger, David, Introduction to The Christian-Jewish Debate in the High Middle Ages, in: Berger, Persecution, Polemic and Dialogue, 75-109.

Berger, David, Persecution, Polemic, and Dialogue: Essays in Jewish-Christian Relations, Judaism and Jewish Life (Boston, 2010).

Berger, David, How, When, and to What Degree Was the Jewish-Christian Debate Transformed in the Twelfth and Thirteenth Centuries?, in: Elisheva Baumgarten and Judah D. Galinsky (eds.), Jews and Christians in Thirteenth-Century France (New York, 2015) 123-137.

Berger, David, Perlmann, Moshe and Daniel, Norman, Polemics, in: Lindsay Jones (ed.), Encyclopedia of Religion, Vol. 11 (Detroit, 2005) 7230-7244.

Biller, Peter, Words and the Medieval Notion of >Religion', Journal of Ecclesiastical History 36/3 (1985) 351-369.

Blumenkranz, Bernhard, Les auteurs Chrétiens latins du Moyen Âge sur les Juifs et le Judaïsme, Collection de la Revue des Études Juives (Paris, 2007). 
Bonfil, Robert, Irshai, Oded, Stroumsa, Guy G., and Talgam, Rina (eds.) Jews in Byzantium: Dialectics of Minority and Majority Cultures, Jerusalem Studies in Religion and Culture (Leiden, 2011).

Borgolte, Michael, and Schneidmüller, Bernd (eds.), Hybride Kulturen im mittelalterlichen Europa: Vorträge und Workshops einer internationalen Frühlingsschule, Europa im Mittelalter. Abhandlungen und Beiträge zur historischen Komparatistik 16 (Berlin, 2010).

Bouhaïk-Gironès, Marie, Debbagi Baranova, Tatiana, and Szczech, Nathalie (eds.), Usages et stratégies polémiques en Europe: (XIVe-premier XVIIe siècles) (Brussels, 2016).

Bouquet, Damien, and Nagy, Piroska, Sensible Moyen Âge: une histoire des émotions dans l'Occident médiéval, L'univers historique (Paris, 2015).

Bourdieu, Pierre, Genèse et structure du champ religieux, Revue française de sociologie 12/3 (1971) 295-334.

Boyarin, Daniel, Border Lines: The Partition of Judaeo-Christianity (Philadelphia, Pennsylvania, 2010).

Brandes, Wolfram, Schmieder, Felicitas, and Voss, Rebekka (eds.), Peoples of the Apocalypse: Eschatological Beliefs and Political Scenarios, Millenium-Studien zu Kultur und Geschichte des ersten Jahrtausends/Millennium Studies in the Culture and History of the First Millennium 63 (Berlin, 2016).

Brauner, Christina, and Steckel, Sita, Wie die Heiden - Wie die Papisten. Religiöse Polemik und Vergleiche vom Spätmittelalter bis zur Konfessionalisierung, in: Matthias Pohlig (ed.), Juden, Christen und Muslime im Zeitalter der Reformation, Schriften des Vereins für Reformationsgeschichte 220 (Gütersloh, 2019) (forthcoming).

Bremer, Kai, Religionsstreitigkeiten: Volkssprachliche Kontroversen zwischen altgläubigen und evangelischen Theologen im 16. Jahrhundert (Berlin, 2005).

Bremer, Kai, and Spoerhase, Carlos (eds.) Gelehrte Polemik. Intellektuelle Konfliktverschärfungen um 170o, Zeitsprünge. Forschungen zur Frühen Neuzeit 15 (Frankfurt/Main, 2011).

Bremer, Kai, and Spoerhase, Carlos (eds.), "Theologisch-polemisch-poetische Sachen «: Gelehrte Polemik im 18. Jahrhundert, Zeitsprünge. Forschungen zur Frühen Neuzeit 19 (Frankfurt am Main, 2015).

Bremer, Kai, and Spoerhase, Carlos, Rhetorische Rücksichtslosigkeit. Problemfelder der Erforschung gelehrter Polemik um 1700, in: Bremer and Spoerhase, Gelehrte Polemik, 111122.

Brentjes, Sonja, Medieval Portolan Charts as Documents of Shared Cultural Spaces, in: Rania Abdellatif, Yassir Benhima, Daniel König, and Elisabeth Ruchaud (eds.), Acteurs des transferts culturels en Méditerranée médiévale, Ateliers des DHI Paris 9 (München, 2012) 135-146.

Brentjes, Sonja, Fidora, Alexander, and Tischler, Matthias M., Towards a New Approach to Medieval Cross-Cultural Exchanges, Journal of Transcultural Medieval Studies 1/1 (2014) 9-50.

Bruschi, Caterina, Falsembiante-Inquisitor? Images and Stereotypes of Franciscan Inquisitors between Literature and Juridical Texts, in: Marco Veglia, Lorenzo Paolini, and Riccardo Parmeggiani (eds.), Il mondo errante: Dante fra letteratura, eresia e storia: atti del convegno internazionale di studio: Bertinoro, 13-16 Settembre 2010 (Spoleto, 2013) 99-136.

Bucossi, Alexandra, Dialogue and Anthologies of the Sacred Arsenal by Andronikos Kamateros: Sources, Arrangements, Purposes, in: P. van Deun and C. Macé (eds.), Encyclopedic Trends in Byzantium? Proceedings of the International Conference held in Leuven, 6-8 May 2009, Orientalia Lovaniensia Analecta 212 (Leuven, 2011) 269-286. 
Burman, Thomas E., Religious Polemic and the Intellectual History of the Mozarabs: C. 10501200 (Leiden, 1994).

Burrows, Daron L., The Stereotype of the Priest in the Old French Fabliaux: Anticlerical Satire and Lay Identity (Oxford, 2005).

Butler, Judith, Excitable Speech: A Politics of the Performative (New York, 1997).

Büttgen, Philippe, De Libera, Alain, Catach-Rosier, Irene, and Rashed, Marwan (eds.), Les Grecs, les Arabes et nous: enquête sur l'islamophobie savante (Paris, 2009).

Cailly, Marie, Les fabliaux - la satire et son public: l'oralité dans la poésie satirique et profane en France, XIIe-XIVe siècles (Cahors, 2007).

Cancik, Hubert, Apologetik/Polemik, in: Hubert Cancik (ed.), Handbuch Religionswissenschaftlicher Grundbegriffe, Vol. 2: Apokalyptik - Geschichte (Stuttgart, 1990) 29-37.

Carlebach, Elisheva, and Schacter, Jacob J. (eds.), New Perspectives on Jewish-Christian Relations. In Honor of David Berger, The Brill Reference Library of Judaism 33 (Leiden, 2012).

Cavarzere, Marco, A Comparative Method for Sixteenth-Century Polemicists: Cults, Devotions, and the Formation of Early Modern Religious Identities, Journal of Early Modern History 19/5 (2015) 385-407.

Chazan, Robert, From Anti-Judaism to Anti-Semitism: Ancient and Medieval Constructions of Jewish history (Cambridge, 2016).

Classen, Albrecht (ed.), Laughter in the Middle Ages and Early Modern Times: Epistemology of a Fundamental Human Behavior, its Meaning, and Consequences, Fundamentals of Medieval and Early Modern Culture 5 (New York, 2010).

Clement, Jennifer, Introduction: Rhetoric, Emotion and the Early Modern English Sermon, English Studies 98/7 (2017) 655-660.

Cluse, Christoph (ed.), Europas Juden im Mittelalter: Beiträge des internationalen Symposiums in Speyer vom 20.-25. Oktober 2002 (Trier, 2004).

Cohen, Jeremy, Towards a Functional Classification of Jewish anti-Christian Polemic in the High Middle Ages, in: Bernard Lewis und Friedrich Niewöhner (eds.), Religionsgespräche im Mittelalter, Wolfenbütteler Mittelalter-Studien 4 (Wiesbaden, 1992) 93-114.

Cohen, Jeremy, Living Letters of the Law. Ideas of the Jew in Medieval Christianity (Berkeley, 1999).

Cohen, Jeremy (ed.), The Postcolonial Middle Ages, The New Middle Ages (New York, 2000).

Cohen, Mark R. The Middle Ages, in: Abdelwahab Meddeb, Michael B Smith, Benjamin Stora and Jane Marie Todd (eds.), A History of Jewish-Muslim Relations from the Origins to the Present Day (Princeton, 2013) 28-163.

Coleman, Edward, Nasty Habits - Satire and the Medieval Monk, History Today 43/6 (1993) 36-42.

Colominas Aparicio, Mònica, The Religious Polemics of the Muslims of Late Medieval Christian Iberia. Identity and Religious Authority in Mudejar Islam, The Medieval and Early Modern Iberian World 64 (Leiden, 2018) forthcoming.

Conermann, Stephan (ed), Muslim-Jewish Relations in the Middle Islamic Period: Jews in the Ayyubid and Mamluk Sultanates (1171-1517), Mamluk Studies 16 (Göttingen, 2017).

Conklin Akbari, Suzanne, Idols in the East: European representations of Islam and the Orient, 1100-1450 (Ithaca, New York, 2009).

Connell, Charles W., Popular Opinion in the Middle Ages: Channeling Public Ideas and Attitudes, Fundamentals of Medieval and Early Modern Culture 18 (Berlin, 2016).

Corbellini, Sabrina (ed.), Cultures of Religious Reading in the Late Middle Ages: Instructing the Soul, Feeding the Spirit, and Awakening the Passion (Turnhout, 2013). 
Cuffel, Alexandra, Gendering Disgust in Medieval Religious Polemic (Notre Dame, Indiana, 2007).

Cuffel, Alexandra, The Matter of Others: Menstrual Blood and Uncontrolled Semen in Thirteenth-Century Kabbalist's Polemic Against Christians, >Bad Jews and Muslims, in: Katherine Allan Smith and Scott Wells (eds.), Negotiating Community and Difference in Medieval Europe: Gender, Power, Patronage and the Authority of Religion in Latin Christiandom, Studies in the History of Christian Tradition 142 (Leiden, 2009) 249-284.

Cuffel, Alexandra, Ibn Sahula's Meshal Ha-Qadmoni as Restorative Polemic, Journal of Medieval Iberian Studies 3/2 (2011) 165-186.

Cuffel, Alexandra, Between Epic Entertainment and Polemical Exegesis: Jesus as Antihero in Toledot Yeshu, in: Ryan Szpiech (ed.) Medieval Exegesis and Religious Difference: Commentary, Conflict, and Community in the Premodern Mediterranean, Bordering Religions (New York, 2015) 155-170.

Dahan, Gilbert. Les intellectuels chrétiens et les juifs au Moyen Âge, Patrimoines (Paris, 1990).

Dahan, Gilbert, The Christian Polemic Against the Jews in the Middle Ages (Notre Dame, Indiana, 1998).

Dascal, Marcelo, On the Uses of Argumentative Reason in Religious Polemics, in: Theo L. Hettema und Arie Van der Kooij (eds.), Religious Polemics in Context, Papers Presented to the Second International Conference of the Leiden Institute for the Study of Religions (LISOR), held at Leiden, 27-28 April 2000, Studies in Theology and Religion 11 (Assen, 2004) 3-20.

Daston, Lorraine, and Galison, Peter (eds.), Objectivity (New York, Massachusetts, 2007).

Dege-Müller, Sophia, Between Heretics and Jews: Inventing Jewish Identities in Ethiopia, Entangled Religions 6 (2018) 247-308.

De Jong, Mayke, Admonitio and Criticism of the Ruler at the Court of Louis the Pious, in: François Bougard, Régine Le Jan, and Rosamond McKitterick (eds.), La culture du haut Moyen Âge: Une question d'élites? Collection Haut Moyen Âge 7 (Turnhout, 2009) 315-138.

De Libera, Alain, Penser au Moyen Âge, Chemins de pensée (Paris, 1991).

Desmons, Eric, and Paveau, Marie-Anne (eds.), Outrages, insultes, blasphèmes et injures: violences du langage et polices $d u$ discours (Paris, 2008).

Destemberg, Antoine, L'espace public de la polémique: lecture croisée, in: Sère, Régimes de la polémicité, forthcoming.

Di Cesare, Michelina, The Pseudo-Historical Image of the Prophet Muhammad in Medieval Latin Literature: A Repertory, Studien zur Geschichte und Kultur des islamischen Orients 26 (Berlin, 2011).

Diamond, James A., Converts, Heretics, and Lepers: Maimonides and the Outsider (Notre Dame, Indiana, 2007).

Doležalová, Lucie, Passion and Passion: Intertextual Narratives from Late Medieval Bohemia between Typology, History and Parody, in: Marek Thue Kretschmer (ed.), La Typologie biblique comme forme de pensée dans l'historiographie médiévale (Turnhout, 2014) 245-265.

Donneaud, Henry, Histoire d'une histoire. M.-D. Chenu et La théologie comme science au XIIIe siècle, Mémoire Dominicaine. Histoire-Documents-Vie dominicaine 4 (1994) 139-175.

Douglas, Mary, Purity and Danger: An Analysis of Concepts of Pollution and Taboo, Collected Works 2 (London - New York, 2013).

Drews, Wolfram, and Scholl, Christian (eds.), Transkulturelle Verflechtungsprozesse in der Vormoderne, Das Mittelalter. Perspektiven mediävistischer Forschung, Beihefte 3 (Berlin, 2016). 
Duschinsky, Robbie, Weiss, Daniel H., and Schnall, Simone (eds.), Purity and Danger Now: New Perspectives (London, 2016).

Dykema, Peter A., and Oberman, Heiko A. (eds.), Anticlericalism in Late Medieval and Early Modern Europe, Studies in Medieval and Reformation Thought 51 (Leiden, 1993).

Elmer, Ian J., Pillars, Hypocrites and False Brothers. Paul's Polemic against Jerusalem in Galatians, in: Oda Wischmeyer and Lorenzo Scornaienchi (eds.), Polemik in der frühchristlichen Literatur. Texte und Kontexte, Beihefte zur Zeitschrift für die neutestamentliche Wissenschaft und die Kunde der älteren Kirche 170 (Berlin, 2011) 123-153.

Emmerson, Richard K., and Herzman, Ronald B., The Apocalyptic Age of Hypocrisy: Faus Semblant and Amant in the Roman de la Rose, Speculum 62/3 (1987) 612-634.

Epple, Angelika, Doing Comparisons - ein praxeologischer Zugang zur Geschichte der Globalisierung/en, in: Angelika Epple and Walter Erhart (eds.), Die Welt beobachten. Praktiken des Vergleichens (Frankfurt, 2015) 161-199.

Epstein, Marc Michael, Dreams of Subversion in Medieval Jewish Art and Literature. (Philadelphia, Pennsylvania, 1997).

Ess, Josef van, Der Eine und das Andere: Beobachtungen an islamischen häresiographischen Texten, Studien zur Geschichte und Kultur des islamischen Orients N. F. 23 (Berlin, 2011).

Fidora, Alexander, The Latin Talmud and Its Place in Medieval Anti-Jewish Polemic, in: Ulisse Cecini and Eulàlia Vernet (eds.), Studies on the Latin Talmud (Bellaterra, 2017) 13-21.

Fierro, Maribel (ed.), Orthodoxy and Heresy in Islam, Critical Concepts in Islam, 4 vols. (Abingdon, 2014).

Fierro, Maribel, and Tolan, John V. (eds.), The Legal Status of Dimmi-s in the Islamic West: Second, Eighth-Ninth, Fifteenth Centuries, Religion and Law in Medieval Christian and Muslim Societies 1 (Turnhout, 2013).

Flasch, Kurt, and Jeck, Udo Reinhold (eds.), Das Licht der Vernunft. Die Anfänge der Aufklärung im Mittelalter (München, 1997).

Foucault, Michel, Polemics, Politics and Problematizations, Paul Rabinow (ed.), Essential Works of Foucault 1954-1984, Vol. 1: Ethics: Subjectivity and Truth, translated by Robert Hurley (London, 2000) 111-119.

Frakes, Jerold C. (ed.), Contextualizing the Muslim Other in Medieval Christian Discourse, The New Middle Ages (New York, 2011).

Frank, Daniel, The Jews of Medieval Islam: Community, Society, and Identity (Leiden, 1995).

Fraser, Nancy, Rethinking the Public Sphere: A Contribution to the Critique of Actually Existing Democracy, Social Text 25-26 (1990) 56-80.

Frassetto, Michael (ed.), Heresy and the Persecuting Society in the Middle Ages: Essays on the Work of R. I. Moore, Studies in the History of Christian Traditions 129 (Leiden, 2006).

Freidenreich, David M., and Goldstein, Miriam (eds.), Beyond Religious Borders: Interaction and Intellectual Exchange in the Medieval Islamic World (Philadelphia, 2011).

Freidenreich, David, Foreigners and Their Food. Constructing Otherness in Jewish, Christian, and Islamic Law (Berkeley, 2014).

Freudenberg, Bele, Irarum nutrix. Emotionen und Ehrverletzungen bei William of Newburgh, Richard of Devizes und Walter Map (Bochum, 2014).

Freudenthal, Gad, Arabic into Hebrew: The Emergence of the Translation Movement in Twelfth-Century Provence and Jewish-Christian Polemic, in: Freidenreich and Goldstein, Beyond Religious Borders, 124-143.

Friedmann, Yohanan, Tolerance and Coercion in Islam: Interfaith Relations in the Muslim Tradition (Cambridge, 2003). 
Füssel, Marian, Die Gelehrtenrepublik im Kriegszustand. Zur bellizitären Metaphorik von gelehrten Streitkulturen der Frühen Neuzeit, in: Kai Bremer und Carlos Spoerhase (eds.), Gelehrte Polemik. Intellektuelle Konfliktverschärfungen um 1700, Zeitsprünge. Forschungen zur Frühen Neuzeit 15 (Frankfurt am Main, 2011) 158-175.

Funkenstein, Amos, Basic Types of Christian Anti-Jewish Polemics in the Later Middle Ages, Viator 2 (1971) 373-382.

Gálik, Marián, and Slobodník, Martin (eds), Eastern Christianity, Judaism and Islam between the Death of Muhammad and Tamerlane (632-1405) (Bratislava, 2011).

Garcia, Michel, and Beaumatin, Eric (eds.), L'invective au Moyen Âge: France, Espagne, Italie, Actes du colloque "L'invective au Moyen Âge", Paris, 4-6 février 1993 (Paris, 1995).

Garloff, Mona, Irenik, Gelehrsamkeit und Politik: Jean Hotman und der europäische Religionskonflikt um 1600, Schriften zur politischen Kommunikation 18 (Göttingen, 2014).

Gaunt, Simon, Can the Middle Ages Be Postcolonial?, Comparative Literature 61/2 (2009) 160-176.

Gay, Jean-Pascal, Lettres de controverse. Religion, publication et espace public en France au xviie siècle, Annales. Histoire, Sciences Sociales, 68/1 (2013) 7-41.

Geltner, Guy, The Making of Medieval Antifraternalism: Polemic, Violence, Deviance, and Remembrance (Oxford, 2012).

Gierl, Martin, Pietismus und Aufklärung. Theologische Polemik und die Kommunikationsreform der Wissenschaft am Ende des 17. Jahrhunderts, Veröffentlichungen des Max-Planck-Instituts für Geschichte 129 (Göttingen, 1997).

Gieryn, Thomas F. Boundary-Work and the Demarcation of Science from Non-Science: Strains and Interests in Professional Ideologies of Scientists, American Sociological Review 48/6 (1983) 781-795.

Giraud, Cédric, Discours magistral, parole d'autorité et violence cachée dans les sentences d'Anselme de Laon († 1117), in: Azoulay and Boucheron, Le mot qui tue, 263-274.

Glei, Reinhold F., and Reichmuth, Stefan, Religion between Last Judgement, Law and Faith. Koranic din and its rendering in the Latin Translations of the Koran, Religion 42/2 (2012) 247-271.

Goertz, Hans-Jürgen, Antiklerikalismus und Reformation. Sozialgeschichtliche Untersuchungen (Göttingen, 1995).

Goetz, Hans-Werner, Die Wahrnehmung anderer Religionen und christlich-abendländisches Selbstverständnis im frühen und hohen Mittelalter (5.-12. Jahrhundert), 2 vols. (Berlin, 2013).

Gorisse, Marie-Helene, The Taste of the Mango: A Jaina-Buddhist Controversy on Evidence, International Journal of Jaina Studies 11/3 (2015) 1-19.

Groebner, Valentin, Defaced: The Visual Culture of Violence in the Late Middle Ages (New York, 2004).

Grundmann, Herbert, Ketzerverhöre des Spätmittelalters als quellenkritisches Problem, in: Herbert Grundmann, Ausgewählte Aufsätze, Band 1: Religiöse Bewegungen, Schriften der Monumenta Germaniae Historica 25 ( Stuttgart, 1976) 360-416.

Grundmann, Herbert, Religious Movements in the Middle Ages: The Historical Links between Heresy, the Mendicant Orders, and the Women's Religious Movement in the Twelfth and Thirteenth Century, with the Historical Foundations of German Mysticism (Notre Dame, Indiana, 1995).

Habermas, Jürgen, Strukturwandel der Öffentlichkeit. Untersuchungen zu einer Kategorie der bürgerlichen Gesellschaft. Mit einem Vorwort zur Neuauflage von 1990, Suhrkamp Taschenbuch Wissenschaft 891 (Frankfurt am Main, 1990). 
Hames, Harvey J., Reconstructing Thirteenth-Century Jewish-Christian Polemic: From Paris 1240 to Barcelona 1263 and Back Again, in: Szpiech, Medieval Exegesis and Religious Difference, $115-127$.

Hamm, Berndt, Was ist Frömmigkeitstheologie? Überlegungen zum 14. bis 16. Jahrhundert, in: Reinhold Friedrich and Wolfgang Simon (eds.), Religiosität im späten Mittelalter: Spannungspole, Neuaufbrüche, Normierungen, Spätmittelalter, Humanismus, Reformation 54 (Tübingen, 2011) 115-153.

Hasselhoff, Görge K., Huldrych Zwinglis Verständnis von religio (’Religion'), Zeitschrift für Religions- und Geistesgeschichte 67/2 (2015) 120-141.

Hasselhoff, Görge K., and Stünkel, Knut Martin (eds.), Transcending Words: The Language of Religious Contact between Buddhists, Christians, Jews, and Muslims in Premodern Times (Bochum, 2015).

Helmrath, Johannes, Streitkultur. Die "Invektive« bei den italienischen Humanisten, in: Marc Laureys and Roswitha Simon (eds.), Die Kunst des Streitens. Inszenierung, Formen und Funktionen öffentlichen Streits in historischer Perspektive (Göttingen, 2010) 259-294.

Herbers, Klaus, and Jaspert, Nikolas (eds.), Integration, Segregation, Vertreibung. Religiöse Minderheiten und Randgruppen auf der Iberischen Halbinsel (7. bis 17. Jahrhundert), Geschichte und Kultur der Iberischen Welt 8 (Münster, 2011).

Henderson, John B, The Construction of Orthodoxy and Heresy: Neo-Confucian, Islamic, Jewish, and Early Christian Patterns (Albany, New York, 1998).

Hess, Cordelia, and Adams, Jonathan (eds.), Fear and Loathing in the North: Jews and Muslims in Medieval Scandinavia and the Baltic Region (Berlin, 2015).

Hettema, Theo L., and Arie van der Kooij (eds.), Religious Polemics in Context: Papers Presented to the Second International Conference of the Leiden Institute for the Study of Religions (Lisor) held at Leiden, 27-28 April, 2000, Studies in Theology and Religion 11 (Assen, 2004).

Hettema, Theo L., and Van der Kooij, Arie, Introduction, in: Hettema and Van der Kooij, Religious Polemics in Context, xi-xxv.

Hirschi, Caspar, Piraten der Gelehrtenrepublik. Die Norm des sachlichen Streits und ihre polemische Funktion, in: Bremer and Spoerhase, Gelehrte Polemik, 176-213.

Hobbins, Daniel, Authorship and Publicity Before Print: Jean Gerson and the Transformation of Late Medieval Learning, Middle Ages Series (Philadelphia, Pennsylvania, 2011).

Höckelmann, Michael, Antiklerikalismus und Exklusionsrhetorik in der Tang-Zeit. Religionspolitik im Denken Li Deyus, Bochumer Jahrbuch zur Ostasienforschung 34 (2010) 181213.

Höfert, Almut, Europa und der Nahe Osten. Der transkulturelle Vergleich in der Vormoderne und die Meistererzählungen über den Islam, Historische Zeitschrift 287/3 (2008) 561-597.

Höfert, Almut, Den Feind beschreiben: "Türkengefahr« und europäisches Wissen über das Osmanische Reich 1450-1600 (Campus Historische Studien 35 (Frankfurt/Main, 2003).

Höfert, Almut, Alteritätsdiskurse. Analyseparameter historischer Antagonismusnarrative und ihre historiographischen Folgen, in: Gabriele Haug-Moritz and Ludolf Pelizaeus (eds.), Repräsentationen der islamischen Welt im Europa der Frühen Neuzeit (Münster, 2010) 21-40.

Hohlstein, Michael, Soziale Ausgrenzung im Medium der Predigt. Der franziskanische Antijudaismus im spätmittelalterlichen Italien, Norm und Struktur. Studien zum sozialen Wandel im Mittelalter und Früher Neuzeit 35 (Cologne, 2012).

Holzem, Andreas (ed.), Krieg und Christentum. Religiöse Gewalttheorien in der Kriegserfahrung des Westens, Krieg in der Geschichte 50 (Paderborn, 2009). 
Hovden, Eirik, Lutter, Christina, and Pohl, Walter (eds.), Meanings of Community across Medieval Eurasia: Comparative Approaches, Brill's Series on the Early Middle Ages 25 (Leiden, 2016).

Hoyland, Robert G. (ed.), Muslims and Others in Early Islamic Society, The Formation of the Classical Islamic World 18 (Burlington, Vermont, 2004).

Huot, Sylvia, The Romance of the Rose and Its Medieval Readers: Interpretation, Reception, Manuscript Transmission, Cambridge Studies in Medieval Literature 16 (Cambridge, 1993).

Hureau, Sylvie, L'apparition de thèmes anticléricaux dans la polémique anti-bouddhique médiévale, Extrême-Orient, Extrême-Occident 24 (2002) 17-29.

Iogna-Prat, Dominique, Order and Exclusion: Cluny and Christendom Face Heresy, Judaism, and Islam (1000-1150), Conjunctions of Religion and Power in the Medieval Past (Ithaca, New York, 2002).

Iricinschi, Eduard, and Zellentin, Holger M. (eds.) Heresy and Identity in Late Antiquity, Texts and Studies in Ancient Judaism/Texte und Studien zum antiken Judentum 119 (Tübingen, 2008).

Iyengar, Shanto, and Westwood, Sean Jeremy, Fear and Loathing Across Party Lines: New Evidence on Group Polarization, American Journal of Political Science 59/3 (2015) 690-707.

Jaspert, Nikolas, Communicating Vessels: Ecclesiastic Centralisation, Religious Diversity and Knowledge in Medieval Latin Europe, The Medieval History Journal 16/2 (2013) 389-424.

Jaspert, Nikolas, Politische Öffentlichkeit im Spätmittelalter: Zusammenfassung, in: Martin Kintzinger and Bernd Schneidmüller (eds.), Politische Öffentlichkeit im Spätmittelalter, Vorträge und Forschungen 75 (Ostfildern, 2011) 433-449.

Johnson, Hannah, and Blurton, Heather, Virtual Jews and Figural Criticism: Recent Scholarship on the Idea of the Jew in Western Culture, Philological Quarterly 92/1 (2013) 115-130.

Keil, Martha, Orte jüdischer Öffentlichkeit: Judenviertel, Synagoge, Friedhof, in: Eveline Brugger und Birgit Wiedl (eds.), Ein Thema - zwei Perspektiven: Juden und Christen in Mittelalter und Frühneuzeit (Innsbruck, 2007) 170-188.

Kendrick, Laura, Medieval Satire, in: Ruben Quintero (ed.), A Companion to Satire: Ancient and Modern (Oxford, 2007) 52-68.

Kerby-Fulton, Kathryn, Hayton, Magda, and Olsen, Kenna, Pseudo-Hildegardian Prophecy and Antimendicant Propaganda in Late Medieval England: An Edition of the Most Popular Insular Text of 'Insurgent Gentes‘, in: Nigel John Morgan (ed.), Prophecy, Apocalypse and the Day of Doom: Proceedings of the 2000 Harlaxton Symposium, Harlaxton Medieval Studies (Donington, 2004) 160-194.

Kessler, Herbert L., and Nirenberg, David (eds.), Judaism and Christian Art: Aesthetic Anxieties from the Catacombs to Colonialism (Philadelphia, Pennsylvania, 2012).

Kienzle, Beverly Mayne, Preaching as Touchstone of Orthodoxy and Dissidence in the Middle Ages, Medieval Sermon Studies 43 (1999) 19-54.

Kim, Dorothy, Reframing Race and Jewish/Christian Relations in the Middle Ages, Transversal 13/ 1 (2015) 52-64.

Kindermann, Udo, Satyra: Die Theorie der Satire im Mittellateinischen: Vorstudie zu einer Gattungsgeschichte, Erlanger Beiträge zur Sprach- und Kunstwissenschaft 58 (Nürnberg, 1978).

Knappe, Gabriele, Flyting und die Rhetorik des verbalen Konflikts in der angelsächsischen Literatur, in: Oliver Auge, Felix Biermann, Matthias Müller, Dirk Schultze (eds.), Bereit zum Konflikt. Strategien und Medien der Konflikterzeugung (Stuttgart, 2008) 31-46. 
Koch, Bettina, Patterns Legitimizing Political Violence in Transcultural Perspectives: Islamic and Christian Traditions and Legacies, Judaism, Christianity, and Islam - Tension, Transmission, Transformation 1 (Boston, 2015).

König, Daniel, Ausstrahlung - transkulturelle Datenmigration - Dokumentation. Arabischislamische Gelehrte und die Herausforderungen der Dokumentation Lateineuropas am Beispiel des Papsttums und des ostfränkisch-deutschen Reiches, in: Michael Borgolte and Matthias M. Tischler (eds.), Transkulturelle Verflechtungen im mittelalterlichen Jahrtausend. Europa, Ostasien, Afrika (Darmstadt, 2012) 207-240.

König, Daniel, Arabic-Islamic Views of the Latin West: Tracing the Emergence of Medieval Europe (Oxford, 2015).

Kohn, Livia, Laughing at the Tao: Debates among Buddhists and Taoists in Medieval China (Princeton, 1995).

Krech, Volkhard, and Schwartz, Yossef (eds.), Religious Apologetics - Philosophical Argumentation, Religion in Philosophy and Theology 10 (Tübingen, 2004).

Krech, Volkhard, and Steinicke, Marion (eds.), Dynamics in the History of Religions Between Asia and Europe: Encounters, Notions, and Comparative Perspectives. Dynamics in the History of Religions 1 (Leiden, 2012).

Kolbaba, Tia M., The Byzantine Lists: Errors of the Latins, Illinois Medieval Studies (Chicago, 2000).

Lange, Christian, and Fierro, Maribel (eds), Public Violence in Islamic Societies. Power, Discipline and the Construction of the Public Sphere, 7th-19th Centuries CE (Edinburgh, 2009).

L'anticléricalisme en France méridionale (fin XIIe-début XIVe siècle), Cahiers de Fanjeaux 38 (Toulouse, 2003).

Lakoff, George, and Wehling, Elisabeth, Your Brain's Politics: How the Science of Mind Explains the Political Divide, Societas : Essays in Political and Cultural Criticism (Exeter, 2016).

Lambert, Malcolm D., Medieval Heresy: Popular Movements from the Gregorian Reform to the Reformation (Oxford, 2002).

Lasker, Daniel J., Jewish Philosophical Polemics against Christianity in the Middle Ages (New York, 1977).

Lasker, Daniel J., The Impact of Interreligious Polemic on Medieval Philosophy, in: David M. Freidenreich and Miriam Goldstein (eds.), Beyond Religious Borders: Interaction and Intellectual Exchange in the Medieval Islamic World (Philadelphia, Pennsylvania, 2011) 115-123.

Lau, Richard R., Andersen, David J., Ditonto, Tessa M., Kleinberg, Mona S., and Redlawsk, David P., Effect of Media Environment Diversity and Advertising Tone on Information Search, Selective Exposure, and Affective Polarization, Political Behavior 39/1 (2017) 231255.

Laursen, John Christian, Nederman, Cary J. and Hunter, Ian (eds.), Heresy in Transition: Transforming Ideas of Heresy in Medieval and Early Modern Europe (Catholic Christendom, 1300-1700) (Aldershot, 2005).

Lazarus-Yafeh, Hava, Intertwined Worlds: Medieval Islam and Bible Criticism (Princeton, 1992). Lembke, Astrid (ed.), Biblical Creatures - The Animal as an Object of Interpretation in Pre-Modern Abrahamic Hermeneutic Traditions, Special issue of Interfaces: A Journal of Medieval European Literature (2018) forthcoming.

Levine, Robert, Why Praise Jews? History and Satire in the Middle Ages, Journal of Medieval History 12 (1986) 291-296.

Lewis, Bernard and Niewöhner, Friedrich (eds.), Religionsgespräche im Mittelalter, Wolfenbütteler Mittelalter-Studien 4 (Wiesbaden, 1992). 
Limor, Ora, Die Disputationen zu Ceuta (1179) und Mallorca (1286). Zwei antijüdische Schriften aus dem mittelalterlichen Genua, MGH Schriften zur Geistesgeschichte des Mittelalters 15 (Hannover, 1994).

Limor, Ora, Polemical Varietes: Religious Disputations in Thirteenth Century Spain, Iberia Judaica 2 (2010) 55-79.

Limor, Ora and Stroumsa, Guy G. (eds.), Contra Iudaeos: Ancient and Medieval Polemics between Christians and Jews, Texts and Studies in Medieval and Early Modern Judaism 10 (Tübingen, 1996).

Liu, Kwang-Ching and Shek, Richard (eds.), Heterodoxy in Late Imperial China (Honolulu, 2004).

Lourdaux, Willem, and Verhelst, Daniel (eds.), The Concept of Heresy in the Middle Ages (11th13th c.): Proceedings of the International Conference Louvain, May 13-16, 1973 (Leuven, 1976).

Love, Nancy S., Foucault and Habermas on Discourse and Democracy, Polity 22/2 (1989) 269-293.

Lubenow, Jorge Adriano, Public Sphere and Deliberative Democracy in Jürgen Habermas: Theoretical Model and Critical Discourses, American Journal of Sociological Research 2/4 (2012) 58-71.

Lutz-Bachmann, Matthias and Fidora, Alexander (eds.), Juden, Christen und Muslime. Religionsdialoge im Mittelalter (Darmstadt, 2004).

Lutz-Bachmann, Matthias, Rationalität und Religion. Der Beitrag des Thomas von Aquin zu eienr rationalen Grundlegung des Religionsdialogs in der Summa contra gentiles, in: Lutz-Bachmann and Fidora, Juden, Christen und Muslime, 96-118.

Malek, Roman, and Hofrichter, Peter (eds.), Jingjiao: The Church of the East in China and Central Asia, Collectanea Serica (Sankt Augustin, 2006).

Mann, Jill, Chaucer and Medieval Estates Satire: The Literature of Social Classes and the General Prologue to the Canterbury Tales (Cambridge, 1973).

Mann, Jill, Satiric Subject and Satiric Object in Goliardic Literature, Mittellateinisches Jahrbuch 15 (1980) 63-86.

Marcus, George E., Neuman, W. Russell, and MacKuen, Michael, Affective Intelligence and Political Judgment (Chicago, 2000).

Marcus, Ivan, A Jewish-Christian Symbiosis: The Culture of Early Ashkenaz, in: David Biale (ed.), Cultures of the Jews: A New History (New York, 2002) 449-518.

Marmursztejn, Elsa, L'autorité des maîtres: Scolastique, normes et société au XIIIe siècle (Paris, 2007).

Marx, Michael, Pahlitzsch, Johannes, and Weltecke, Dorothea, Östliches Christentum in Geschichte und Gegenwart - Perspektiven und Hindernisse der Forschung, Der Islam. Zeitschrift für Geschichte und Kultur des islamischen Orients 88 (2011) 1-10.

Matthes, Jörg, Framing, Konzepte. Ansätze der Medien- und Kommunikationswissenschaft 10 (Baden-Baden, 2014).

McGuire, Brian Patrick, Anti-Clerical Invective and the Growth of Clerical Satire, 1075-1400, in: Olle Ferm and Bridget Morris (eds.), Master Golyas and Sweden: The Transformation of a Clerical Satire, Sällskapet Runica et Mediaevalia. Scripta Minora 2 (Stockholm, 1997) 45-98.

Melve, Leidulf, Inventing the Public Sphere: The Public Debate During the Investiture Contest (c. 1030-1122), Brill's Studies in Intellectual History 154, 2 vols. (Leiden, 2007). 
Mercier, Franck, and Rosé, Isabelle (eds.), Aux marges de l'hérésie. Inventions, formes et usages polémiques de l'accusation d'hérésie au Moyen Âge, Histoire (Rennes, 2017).

Mews, Constant J., Communautés de savoirs. Écoles et collèges à Paris au XIIIe siècle, Revue de Synthèse 129/6 (2008) 485-507.

Miller, Maureen C. and Wheatley, Edward (eds.), Emotions, Communities, and Difference in Medieval Europe Essays in Honor of Barbara H. Rosenwein (London, 2017).

Miller, Timothy S. and Nesbitt, John W., Walking Corpses: Leprosy in Byzantium and the Medieval West (Ithaca, New York, 2014).

Monagle, Clare, Orthodoxy and Controversy in Twelfth-Century Religious Discourse. Peter Lombard's Sentences and the Development of Theology, Europa Sacra 8 (Turnhout, 2013).

Moore, Robert I., The Formation of a Persecuting Society: Authority and Deviance in Western Europe, 950-1250 (second edition) (Oxford, 2007).

Mulsow, Martin and Rexroth, Frank (eds.), Was als wissenschaftlich gelten darf: Praktiken der Grenzziehung in Gelehrtenmilieus der Vormoderne, Campus Historische Studien 70 (Frankfurt am Main, 2014).

Murphy, Kathryn and Traninger, Anita (eds.), The Emergence of Impartiality, Intersections: Interdisciplinary Studies in Early Modern Culture 31 (Leiden, 2014).

Nagy, Piroska and Boquet, Damien (eds.), Le sujet des émotions au Moyen Âge, Bibliothèque historique et littéraire (Paris, 2008).

Neumann, Uwe, Invektive, in: Gerd Ueding (ed.), Historisches Wörterbuch der Rhetorik Vol. 4: $H u-K$ (Tübingen, 1994) 549-561.

Niesner, Manuela, Wer mit juden well disputiren: Deutschsprachige Adversus-Judaeos-Literatur des 14. Jahrhunderts, Münchener Texte und Untersuchungen zur deutschen Literatur des Mittelalters 128 (Tübingen, 2005).

Nirenberg, David, Communities of Violence: Persecution of Minorities in the Middle Ages (Princeton, 1998).

Nirenberg, David, Anti-Judaism: The History of a Way of Thinking (New York, 2013).

Nirenberg, David, Neighboring Faiths: Christianity, Islam, and Judaism in the Middle Ages and Today (Chicago, 2014).

Nongbri, Brent, Before Religion: A History of a Modern Concept (New Haven, Connecticut, 2015).

Novikoff, Alex J., The Medieval Culture of Disputation: Pedagogy, Practice, and Performance, The Middle Ages series (Philadelphia, 2013).

Opelt, Ilona, Die lateinischen Schimpfwörter und verwandte sprachliche Erscheinungen. Eine Typologie, Bibliothek der klassischen Altertumswissenschaften N. F. 2 (Heidelberg, 1965).

Opelt, Ilona, Die Polemik in der christlichen lateinischen Literatur von Tertullian bis Augustin, Bibliothek der klassischen Altertumswissenschaften, N. F. 63 (Heidelberg, 1980).

Palumbo, Antonello, From Constantine the Great to Emperor Wu of the Liang: The Rhetoric of Imperial Conversion and the Divisive Emergence of Religious Identities in Late Antique Eurasia, in: Arietta Papaconstantinou, Neil McLynn and Daniel Louis Schwartz (eds.), Conversion in Late Antiquity: Christianity, Islam, and Beyond (second edition) (Abingdon, 2016) 95-122.

Pearsall, Derek, Medieval Monks and Friars: Differing Literary Perceptions, in: Robert F. Yeager, Toshiyuki Takamiya, und Terry Jones (eds.), The Medieval Python: The Purposive and Provocative Work of Terry Jones, The New Middle Ages (New York, 2012) 59-73.

Pietsch, Andreas N., Isaac La Peyrère: Bibelkritik, Philosemitismus und Patronage in der Gelehrtenrepublik des 17. Jahrhunderts, Frühe Neuzeit 163 (Berlin, 2012). 
Pietsch, Andreas N., Die junge Republik und ihre Konfession. Wahrheits- und Interessenkonflikte auf der Synode von Dordrecht (1618/19), in: Christoph Dartmann, Andreas Nikolaus Pietsch and Sita Steckel (eds.), Ecclesia disputans. Die Konfliktpraxis vormoderner Synoden zwischen Religion und Politik, Historische Zeitschrift Beihefte N. F. 67 (Berlin, 2015) 253-282.

Pietsch, Andreas N., and Steckel, Sita, New Religious Movements before Modernity? Observations from a Historical Perspective, Nova Religio: The Journal of Alternative and Ermergent Religions 22/1 (2018) forthcoming.

Piron, Sylvain, Écrire en aveugle. Jean de Roquetaillade ou la dissidence par l'obéissance, in: Gian Luca Potestà (ed.), Autorität und Wahrheit. Kirchliche Vorstellungen, Normen und Verfahren (13.-15. Jahrhundert), Schriften des Historischen Kollegs. Kolloquien 84 (München, 2012) 91-112.

Plamper, Jan, The History of Emotions: An Introduction (Oxford, 2015).

Pogossian, Zara, The Conceptual Frontier: The Armenian Church and its Relations with the Holy See (XI-XIIIth Centuries), in: Outi Merisalo, Frontiers in the Middle Ages (Louvain-laNeuve, 2006), 259-290.

Pogossian, Zaroui, Jews in Armenian Apocalyptic Traditions of the 12th century: A Fictional Community or New Encounters?, in: Wolfram Brandes, Felicitas Schmieder and Rebekka Voss (eds.), Peoples of the Apocalypse: Eschatological Beliefs and Political Scenarios, Millennium-Studien/Millennium studies 63 (Berlin, 2016) 147-192.

Przybilski, Martin, Zwei Beispiele antichristlicher Polemik in Spätantike und Mittelalter (תודלות ןשי tol'dot jeshu) und (ווחצנ ןשי nizzachon jaschan), in: Eveline Brugger and Birgit Wiedl (eds.), Ein Thema - zwei Perspektiven: Juden und Christen in Mittelalter und Frühneuzeit (Innsbruck, 2007) 253-268.

Ragacs, Ursula, "Mit Zaum und Zügel muss man ihr Ungestüm bändigen " Ps. 32, 9: Ein Beitrag zur christlichen Hebraistik und antijüdischen Polemik im Mittelalter, Judentum und Umwelt 65 (Frankfurt/Main, 1997).

Ragacs, Ursula, Reconstructing Medieval Jewish-Christian Disputations, in: Szpiech, Medieval Exegesis and Religious Difference, 101-114.

Resnick, Irven M., Good Dog/Bad Dog: Dogs in Medieval Religious Polecmics, Enarratio 18 (2013) 70-97.

Richardson, Kristina, Blue and Green Eyes in the Islamicate Middle Ages, Annales Islamologiques 48/1 (2014) 13-30.

Rigo, Antonio and Ermilov, Pavel (eds.), Orthodoxy and Heresy in Byzantium: The Definition and the Notion of Orthodoxy and Some Other Dtudies on the Heresies and the Non-Christian Religions, Quaderni di Néa Rhóme 4 (Rome, 2010).

Robinson, Ian S., Authority and Resistance in the Investiture Contest: The Polemical Literature of the Late Eleventh Century (New York, 1978).

Röcke, Werner and Velten, Hans Rudolf (eds.), Lachgemeinschaften. Kulturelle Inszenierungen und soziale Wirkungen von Gelächter im Spätmittelalter und in der Frühen Neuzeit, Trends in Medieval Philology 4 (Berlin, 2005).

Rose, E. M., The Murder of William of Norwich: The Origins of the Blood Libel in Medieval Europe (Oxford, 2015).

Rosenwein, Barbara H., Generations of Feeling: A History of Emotions, 600-170o (Cambridge, 2016).

Ruani, Flavia (ed.), Les controverses religieuses en syriaque, Etudes syriaques 13 (Paris, 2016). 
Rubin, Miri, Gentile Tales: The Narrative Assault on Late Medieval Jews (Philadelphia, Pennsylvania, 2004).

Rüegg, Walter (ed.), Universities in the Nineteenth and Early Twentieth Centuries (180o-1945), A history of the university in Europe 3 (Cambridge, 2004).

Rustow, Marina, Karaites Real and Imagined: Three Cases of Jewish Heresy, Past \& Present, 197 (2007) 35-74.

Rustow, Marina, Heresy and the Politics of Community: The Jews of the Fatimid Caliphate (Ithaca, New York, 2008).

Sackville, Lucy J., Heresy and Heretics in the Thirteenth Century: The Textual Representations (York, 2011).

Said, Edward W., Orientalism (New York, 1978).

Samir, Samir Halil and Nielsen, Jørgen S. (eds.), Christian Arabic Apologetics During the Abbasid Period (750-1258), Studies in the History of Religions 63 (Leiden, 1994).

Sauer, Birgit, `Bringing emotions back in`. Gefühle als Regierungstechnik: Geschlechterund demokratietheoretische Überlegungen, in: Claudia Jarzebowski and Anne Kwaschik (eds.), Performing Emotions: Interdisziplinäre Perspektiven auf das Verhältnis von Politik und Emotion in der Frühen Neuzeit und in der Moderne (Göttingen, 2013) 241-258.

Scase, Wendy, Piers Plowman and the New Anticlericalism, Cambridge Studies in Medieval Literature 4 (Cambridge, 1989).

Scharff, Thomas, Lachen über Ketzer. Religiöse Devianz und Gelächter im Hochmittelalter, in: Werner Röcke and Hans Rudolf Velten (eds.), Lachgemeinschaften: Kulturelle Inszenierungen und soziale Wirkungen von Gelächter im Mittelalter und in der frühen Neuzeit, Trends in Medieval Philology 4 (Berlin, 2005) 17-31.

Scheuer, Hans Jürgen and Veder, Ulrike (eds.), Tier im Text. Exemplarität und Allegorizität literarischer Lebewesen, Publikationen zur Zeitschrift für Germanistik N. F. 29 (Berne, 2015).

Schlögl, Rudolf, Politik beobachten. Öffentlichkeit und Medien in der Frühen Neuzeit, Zeitschrift für historische Forschung 35 (2008) 581-616.

Schmieder, Felicitas, Prophetische Propaganda in der Politik des 14. Jahrhunderts: Johannes von Rupescissa, in: Wolfram Brandes and Felicitas Schmieder (eds.), Endzeiten. Eschatologie in den monotheistischen Weltreligionen, Millenium-Studien zu Kultur und Geschichte des ersten Jahrtausends/Millennium Studies in the Culture and History of the First Millennium 16 (Berlin, 2008) 249-260.

Scholl, Christian, Materielle Hinterlassenschaften als Zeugen christlich-jüdischer Verflechtungen im mittelalterlichen Reich. Eine Skizze, in: Drews and Scholl, Transkulturelle Verflechtungsprozesse in der Vormoderne, 141-155.

Schrage, Eva-Maria, Von Ketzern und Terroristen? Zum analytischen Nutzen eines interdisziplinären Feindbildbegriffs, in: Harutyun Harutyunyan, Alfons Fürst, Eva-Maria Schrage and Verena Voigt (eds.), Von Ketzern und Terroristen: Interdisziplinäre Studien zur Konstruktion und Rezeption von Feindbildern (Münster, 2012) 217-238.

Schüppert, Helga, Kirchenkritik in der lateinischen Lyrik des 12. und 13. Jahrhunderts, Medium Aevum. Philologische Studien 23 (München, 1972).

Scribner, Robert W., Popular Culture and Popular Movements in Reformation Germany (London, 1987).

Scribner, Robert W., For the Sake of Simple Folk: Popular Propaganda for the German Reformation (Oxford, 1994).

Sère, Bénédicte, Thomas d'Aquin contre Siger de Brabant, 1270 : Chronique d'une dispute, in: Azoulay and Boucheron, Le mot qui tue, 99-115. 
Sère, Bénédicte, Les débats d'opinion à l'heure du Grand Schisme. Ecclésiologie et politique, Ecclesia militans 6 (Turnhout, 2016).

Sère, Bénédicte, Introduction, in: Bénédicte Sère (ed.), Les régimes de polémicité (Rennes, 2018) forthcoming.

Sère, Bénédicte (ed.), Les régimes de polémicité au Moyen Âge (Rennes, 2018) forthcoming.

Shachar, Isaiah, The Judensau: A Medieval Anti-Jewish Motif and its History, Warburg Institute Surveys 5 (London, 1974).

Shaked, Shaul, Dualism in Transformation: Varieties of Religion in Sasanian Iran, Jordan Lectures in Comparative Religion 16 (London, 1994).

Shalev-Eyni, Sarit, Martyrdom and Sexuality: The Case of an Eleventh-Century Piyyut for Hannukah and Its Visual Interpretation in the Fifteenth Century, in: Yisrael Yakov Yuval, and Ram Ben-Shalom (eds.), Conflict and Religious Conversation in Latin Christendom: Studies in Honour of Ora Limor, Cultural Encounters in Late Antiquity and the Middle Ages 17 (Turnhout, 2014) 133-166.

Shatzmiller, Joseph, Cultural Exchange: Jews, Christians, and Art in the Medieval Marketplace (Princeton, New Jersey, 2013).

Signori, Gabriela, Frauen, Kinder, Greise und Tyrannen. Geschlecht und Krieg in der Bilderwelt des späten Mittelalters, in: Klaus Schreiner and Gabriela Signori (eds.), Bilder, Texte, Rituale. Wirklichkeitsbezug und Wirklichkeitskonstruktion politisch-rechtlicher Kommunikationsmedien in Stadt- und Adelsgesellschaften des späten Mittelalters, Zeitschrift für Historische Forschung, Beiheft 24 (Berlin, 2000) 139-164.

Simpson, James R., and Roach, Andrew (eds.), Heresy and the Making of European Culture: Medieval and Modern Perspectives (Farnham, 2013).

Sims-Williams, Nicholas, Some Reflections on Zoroastrianism in Sogdiana and Bactria, in: David Christian and Craig Benjamin (eds.), Realms of the Silk Roads: Ancient and Modern (Turnhout, 2000) 1-12.

Smail, Daniel L., The Consumption of Justice: Emotions, Publicity, and Legal Culture in Marseille, 1264-1423 (Ithaca, New York, 2003).

Snoek, Jan A. M., Religious Polemics in Context: An Annotated Bibliography, in: Hettema und van der Kooij, Religious Polemics in Context, 507-588.

Southcombe, George, Suerbaum, Almut and Thompson, Benjamin, Introduction, in: Suerbaum et al., Polemic, 1-14.

Soukup, Pavel, >Pars Machometicar in Early Hussite Polemics: The Use and Background of an Invective, in: Van Dussen and Soukup, Religious Controversy in Europe, 251-287.

Southern, Richard W., Western Views of Islam in the Middle Ages (Cambridge, Massachusetts, 1962).

Southern, Richard W., Medieval Humanism (New York, 1970).

Speer, Andreas, and Steinkrüger, Philipp (eds.), Knotenpunkt Byzanz: Wissensformen und kulturelle Wechselbeziehungen, Miscellanea Mediaevalia 36 (Berlin, 2012).

Stamm, Heinz-Meinolf, Luthers Stellung zum Ordensleben (Stuttgart, 1980).

Stauffer, Hermann, Polemik, in: Gerd Ueding (ed.), Historisches Wörterbuch der Rhetorik, Band 6: Must-Pop (Tübingen, 2003) 1403-1415.

Steckel, Sita, Falsche Heilige. Feindbilder des `Ketzers` in religiösen Debatten des Hoch- und Spätmittelalters, in: Harutyun Harutyunyan, Alfons Fürst, Eva-Maria Schrage and Verena Voigt (eds.), Von Ketzern und Terroristen: Interdisziplinäre Studien zur Konstruktion und Rezeption von Feindbildern (Münster, 2012) 17-44. 
Steckel, Sita, Professoren in Weltuntergangsstimmung. Religiöse Debatte und städtische Öffentlichkeit im Pariser Bettelordensstreit, 1252-1257, in: Jörg Oberste (ed.), Pluralität - Konkurrenz - Konflikt. Religiöse Spannungen im städtischen Raum der Vormoderne, Forum Mittelalter Studien 8 (Regensburg, 2013) 51-74.

Steckel, Sita, Ein brennendes Feuer in meiner Brust. Prophetische Autorschaft und polemische Autorisierungsstrategien Guillaumes de Saint-Amour im Pariser Bettelordensstreit (1256), in: Christel Meier and Martina Wagner-Egelhaaf (eds.), Prophetie und Autorschaft: Charisma, Heilsversprechen und Gefährdung (Berlin, 2014) 129-168.

Steckel, Sita, Une querelle des theologiens? The concept of "polemic « in the historiography of the secular-mendicant controversy, in: Sère, Les régimes de polémicité au Moyen Âge, forthcoming.

Steckel, Satirical Depictions of Monastic Life, in: Alison I. Beach and Isabel Cochelin (eds.), The Cambridge History of Western Monasticism (Cambridge, 2019) forthcoming.

Stenzel, Jürgen, Rhetorischer Manichäismus. Vorschläge zu einer Theorie der Polemik, in: A. Schöne, Kontroversen, alte und neue. Akten des VII. Internationalen GermanistenKongresses, Vol. 2 (Göttingen, 1985) 3-11.

Strauss, Leo, Persecution and the Art of Writing, (Glencoe, Illinois, 1952).

Strickland, Debra Higgs, Saracens, Demons and Jews. Making Monsters in Medieval Art (Princeton, 2003).

Stroumsa, Sarah, Thinkers of `This Peninsular: Toward an Integrative Approach to the Study of Philosophy in Al-Andalus, in: David M. Freidenreich und Miriam Goldstein (eds.), Beyond Religious Borders: Interaction and Intellectual Exchange in the Medieval Islamic World (Philadelphia, Pennsylvania, 2011) 44-56.

Stünkel, Knut Martin, Una sit religio: Religionsbegriffe und Begriffstopologien bei Cusanus, Llull und Maimonides (Würzburg, 2013).

Suchan, Monika, Mahnen und Regieren. Die Metapher des Hirten im früheren Mittelalter. Millennium-Studien/Millennium Studies 56 (Berlin, 2015).

Suerbaum, Almut, Southcombe, George and Thompson, Benjamin (eds.), Polemic: Language as Violence in Medieval and Early Modern Discourse (Farnham, 2015).

Symes, Carol, A Common Stage: Theater and Public Life in Medieval Arras, Conjunctions of Religion and Power in the Medieval Past (Ithaca, New York, 2007).

Szittya, Penn R., The Antifraternal Tradition in Medieval Literature (Princeton, 1986).

Szpiech, Ryan. Conversion and Narrative: Reading and Religious Authority in Medieval Polemic, The Middle Ages Series (Philadelphia, Pennsylvania, 2013).

Szpiech, Ryan (ed.), Medieval Exegesis and Religious Difference: Commentary, Conflict, and Community in the Premodern Mediterranean, Bordering Religions (New York, 2015).

Tang, Li and Winkler, Dietmar W. (eds.), From the Oxus River to the Chinese Shores: Studies on East Syriac Christianity in China and Central Asia, Orientalia - Patristica - Oecumenica 5 (Zürich, 2013).

Taylor, Joan E. (ed.), The Body in Biblical, Christian and Jewish Texts, The Library of Second Temple Studies 85 (London, 2014).

Thomas, David R. and Roggema, Barbara (eds.), Christian-Muslim Relations: A Bibliographical History, Vol. 1 (600-90o) (Leiden, 2009).

Thomas, David and Mallett, Alexander (eds.), Christian-Muslim Relations: A Bibliographical History, Vol. 2 (900-1050) (Leiden, 2010).

Thomas, David and Mallett, Alexander (eds.), Christian-Muslim Relations: A Bibliographical History, Vol. 3 (1050-1200) (Leiden, 2011). 
Thomas, David and Mallett, Alexander (eds.), Christian-Muslim Relations: A Bibliographical History, Vol. 4 (1200-1350) (Leiden, 2012).

Thomas, David and Mallett, Alexander (eds.) Christian-Muslim Relations: A Bibliographical History, Vol. 5 (1350-150o) (Leiden, 2013).

Thompson, Augustine, Lay Versus Clerical Perceptions of Heresy: Protests Against the Inquisition in Bologna, 1299, in: Praedicatores, Inquisitores 1: The Dominicans and the Medieval Inquisition, Acts of the First International Seminar on the Dominicans and the Inquisition. 2325 February 2002, Institutum Historicum Fratrum Praedicatorum Romae Dissertationes Historicae 39 (Rome, 2004) 701-730.

Thompson, Benjamin, The Polemic of Reform in the Later Medieval English Church, in: Suerbaum et al., Polemic, 183-222.

Thum, Bernd, Öffentlichkeit und Kommunikation im Mittelalter. Zur Herstellung von Öffentlichkeit im Bezugsfeld elementarer Kommunikationsformen im 13. Jahrhundert, in: Hedda Ragotzky and Horst Wenzel (ed.), Höfische Repräsentation. Das Zeremoniell und die Zeichen (Berlin, 1990) 65-87.

Till, Dietmar, Text, Kommunikation und Affekt in der Tradition der Rhetorik. Zur Vorgeschichte des `Emotional turn`, Mitteilungen des Deutschen Germanistenverbandes 54/3 (2007) 286-305.

Tischler, Matthias M., and Fidora, Alexander (eds.), Christlicher Norden, Muslimischer Süden: Ansprüche und Wirklichkeiten von Christen, Juden und Muslimen auf der Iberischen Halbinsel im Hoch- und Spätmittelalter, Erudiri Sapientia 7 (Münster, 2011).

Tischler, Matthias M., "Lex Mahometi«. The Authority of a Pattern of Religious Polemics, Journal of Transcultural Medieval Studies 2 (2015) 3-63.

Tolan, John V., Sons of Ishmael: Muslims through European Eyes in the Middle Ages (Gainesville, 2008).

Tolan, John V., Saracens: Islam in the Medieval European Imagination (New York, 2013).

Tolan, John V. and El Anabi, Hassen (eds.), Identités en mutation. L'Europe et le bassin méditerranéen (Frankfurt, 2013).

Tolan, John V., Veinstein, Gilles and Laurens, Henry (eds.), Europe and the Islamic World: A History, translated by Jane Marie Todd (Princeton, 2013).

Tolan, John V., Nicholas De Lang, Capucine Nemo-Pekelman, Laurence Foschia (eds.), Jews in Early Christian Law: Byzantium and the Latin West, 6th-11th Centuries, Religion and Law in Medieval Christian and Muslim Societies 2 (Turnhout, 2014).

Tolan, John V., and Boisselier, Stéphane (eds.), Religious Cohabitation in European Towns (10th -15th Centuries)/La cohabitation religieuse dans les villes européennes, Xe-Xve siècles, Religion and Law in Medieval Christian and Muslim Societies 3 (Turnhout, 2014).

Tomasch, Sylvia, Postcolonial Chaucer and the Virtual Jew, in: Cohen, Postcolonial Middle Ages, 243-260.

Trautner-Kromann, Hanne, Shield and Sword: Jewish Polemics against Christianity and the Christians in France and Spain from 1100-1500, Texts and Studies in Medieval and Early Modern Judaism 8 (Tübingen, 1993).

Trivellone, Alessia, L'hérétique imagine. Hétérodoxie et iconographie dans l'Occident médiéval de l'époque carolingienne à l'Inquisition, Collection d'études médiévales de Nice 10 (Turnhout, 2009).

Utz-Tremp, Kathrin, Von der Häresie zur Hexerei. »Wirkliche« und imaginäre Sekten im Spätmittelalter, MGH Schriften 59 (Hannover, 2008). 
Van Dussen, Michael and Soukup, Pavel (eds.), Religious Controversy in Europe, 1378-1536: Textual Transmission and Networks of Readership, Medieval Church Studies 27 (Turnhout, 2013).

Van der Wall, Ernestine, Ways of Polemicizing: The Power of Tradition in Christian Polemics, in: Hettema and van der Kooij, Religious Polemics in Context, 401-414.

Van Renswoude, Irene and Baumgartner, Christoph, Censorsphip, Free Speech and Religion, in: Paul Hedges (ed.), Controversies in Contemporary Religion: Education, Law, Politics, Society, and Spirituality (Santa Barbara, 2014) 123-151.

Von Karajan, Theodor, Buch der Rügen, Zeitschrift für deutsches Altertum 2 (1842) 6-92.

Von Mutius, Hans-Georg, Rechtsentscheide Raschis von Troyes (1040-1105). Quellen über die sozialen und wirtschaftlichen Beziehungen zwischen Juden und Christen, Judentum und Umwelt 15, 2 vols. (Frankfurt am Main, 1986/1987).

Von Stuckrad, Kocku, Religionsvergleich, in: Friedrich Jaeger (ed.), Enzyklopädie der Neuzeit Online. Retrieved on 22 September 2017: dx.doi.org/10.1163/2352-0248_edn_a3602000.

Walsham, Alexandra, Migrations of the Holy: Explaining Religious Change in Medieval and Early Modern Europe, Journal of Medieval and Early Modern Studies 44/2 (2014) 241-80.

Weijers, Olga, Queritur utrum: Recherches sur la "disputatio" dans les universités médiévales, Studia artistarum 20 (Turnhout, 2009).

Weiler, Björn, Clerical admonitio, Letters of Advice to Kings, and Episcopal Self-Fashioning, c. 1000-c. 1200, History 102/352 (2017) 557-575.

Weltecke, Dorothea, Über Religion vor der `Religion`. Konzeptionen vor der Entstehung des neuzeitlichen Begriffs, in: Thomas G. Kirsch, Rudolf Schlögl and Dorothea Weltecke (eds.), Religion als Prozess. Kulturwissenschaftliche Wege der Religionsforschung (Paderborn, 2015) 13-34.

Weltecke, Dorothea, Space, Entanglement and Decentralisation: On How to Narrate the Transcultural History of Christianity (550 to $1350 \mathrm{CE}$ ), in: Reinhold Glei and Nikolas Jaspert (eds.), Locating Religions: Contact, Diversity, and Translocality, Dynamics in the History of Religions 9 (Leiden, 2017) 315-344.

White, Steven D., The Feelings in the Feud: The Emotional Turn in the Study of Medieval Vengeance, in: Kim Esmark, Lars Hermanson, Hans Jacob Orning and Helle Vogt (eds.), Disputing Strategies in Medieval Scandinavia, Medieval Law and Its Practice 16 (Leiden, 2013) 281-312.

Wiedl, Birgit, Laughing at the Beast: The Judensau. Anti-Jewish Propaganda and Humor from the Middle Ages to the Early Modern Period, in: Albrecht Classen (ed.), Laughter in the Middle Ages and Early Modern Times, Fundamentals of Medieval and Early Modern Culture 5 (Berlin, 2010) 325-364.

Wiegers, Gerard, Fuzzy Categories and Religious Polemics: The Daily Life of Christians and Muslims in the Medieval and Early Modern Mediterranean World, Common Knowledge 19/3 (2013) 474-489.

Wilson, M. Brett, The Failure of Nomenclature: The Concept of `Orthodoxy` in the Study of Islam, Comparative Islamic Studies 3/2 (2007) 169-194.

Wohlfeil, Rainer, >Reformatorische Öffentlichkeit`, in: Karl Stackmann and Ludger Grenzmann (eds.), Literatur und Laienbildung im Spätmittelalter und in der Reformationszeit. Symposion Wolfenbüttel 1981, Germanistische Symposien - Berichtsbände 5 (Stuttgart, 1984) 41-54.

Yuval, Israel Jacob, Pessach und Ostern: Dialog und Polemik in Spätantike und Mittelalter (Trier, 1999). 
Yuval, Israel Jacob, Zwei Völker in deinem Leib. Gegenseitige Wahrnehmung von Juden und Christen in Spätantike und Mittelalter, translated by Dafna Mach, Jüdische Religion, Geschichte und Kultur 4 (Göttingen, 2007).

Yuval, Israel Jacob, and Ben-Shalom, Ram (eds.), Conflict and Religious Conversation in Latin Christendom: Studies in Honour of Ora Limor, Cultural Encounters in Late Antiquity and the Middle Ages 17 (Turnhout, 2014).

Zellentin, Holger M., Rabbinic Parodies of Jewish and Christian Literature, Texte und Studien zum antiken Judentum /Texts and Studies in Ancient Judaism 139 (Tübingen, 2011).

Zürcher, Erich, The Buddhist Conquest of China: The Spread and Adaptation of Buddhism in Early Medieval China, Sinica Leidensia 11 (third edition) (Leiden, 2007). 


\title{
Anti-Jewish Polemics in Business Documents from Late Medieval Austria
}

\author{
Birgit Wiedl*
}

Anti-Jewish polemics can be found in abundance in medieval theology, literature, and art; yet as for documents that stemmed from economic encounters, little research has been done so far. In late medieval Austrian economic source material, only a few hints at anti-Jewish stances can be found in business documents, most of which stem from either an ecclesiastical or a municipal environment. While these brief references to the Jews' interest rates, to Jewish counterfeiting and Jewish duplicity might not be categorized as polemical per se, they introduce polemical stereotypes and arguments into scenarios of everyday Jewish-Christian interaction, and thus contribute to making anti-Jewish sentiment part of the Christian mind-set.

Keywords: Jewish history; anti-Jewish polemics; Jewish-Christian interaction; economic history; business documents

The honorable and wise, our dear friend, Johann (II) Ribi of Platzheim-Lenzburg, bishop of Gurk and chancellor of the Austrian Duke Rudolph IV, addressed the Viennese Jew David Steuss in 1364, when David Steuss had, because of the loyalty and friendship he bears towards us, negotiated a loan of 100 pound pennies from the Viennese Jewish community for the bishop. ${ }^{1}$ Honorific, even flattering forms of addresses from Christians towards their Jewish business partners are rare, although not unheard of, ${ }^{2}$ and those few but noticeable addresses might suggest that references to the contrary, to anti-Jewish stereotypes and prejudices would be even more numerous. By the late thirteenth century, when business charters and other economic or administrative records began to flow in abundance, anti-Jewish sentiments had already been firmly established. Narratives of Jewish usurers, host desecrators and ritual murderers, ${ }^{3}$ of the Jews' obstinacy against Christ and their animosity, even hatred, towards Christianity, their conspiracy with, alternatively, heretics, lepers, and Mongols, ${ }^{4}$ were spread in many ways, and depictions of Jews suckling a sow's teats or being condemned

* Correspondence details: Birgit Wiedl, Institute for Jewish History in Austria, Dr. Karl Renner-Promenade 22, A-3100 St. Pölten. Email: birgit.wiedl@injoest.ac.at.

1 Brugger and Wiedl, Regesten 2, 305-306, no. 1081.

2 The citizens of Prague addressed a Jewish consortium from Prague, Jihlava, and Kutná Hora from which they sought to borrow a considerable sum as prudentis Iudeis in 1392, see Musílek, Juden und Christen, 68.

3 For the vast literature on these topics, see, for comprehensive surveys, Rubin, Gentile Tales; Buttaroni and Musiał, Ritualmord.

4 See Heil, "Gottesfeinde", 272-275 (Knights Templar), 302-308 (Hussites), and 275-285 (lepers); further Yuval, Juden, Hussiten und Deutsche, and idem, Das Jahr 1240 (Mongols). 
to eternal punishment were visible for anyone to see. ${ }^{5}$ Instances of violent persecution give evidence as to how ingrained into the Christian mind-set these stories were by the early fourteenth century - the mere presence of two triggers, a host wafer and a Jew, in the same surrounding set in motion an almost predestined process, and a process that could be relied upon - as seen in the example of the priest of the small Lower Austrian town of Korneuburg, when he, wishing to create a pilgrimage site, planted a host wafer dipped in goat's blood in front of a Jew's house in 1305 , resulting in the murder of the entire Jewish population. ${ }^{6}$

Documents that record the everyday interaction between the Ashkenazi Jews and their Christian neighbours make up the majority of source material, ${ }^{7}$ their number skyrocketing with the Late Middle Ages. So far, however, research concerning anti-Jewish polemics (as cultural studies more generally) rarely looks towards business and its documents as a potential source. ${ }^{8}$

Yet charters have long been recognised as being more than a mere means of recording a business. Their role within the broad field of medieval communication studies has been, and still is, undergoing close scrutiny. Interest has broadened to include their graphic symbols, and, particularly, the rituals that surround their issuance and (public) presentation. ${ }^{9}$ While the focus of research (for now) lies mainly on high medieval charters issued by rulers or high clergy, many of these approaches can be applied to charters of the minor nobility, of citizens, peasants, or, of course, Jews. Not only did the process that led to their issuance include meetings - in public, at the town scribe's office, but perhaps also in the Christian or Jewish business partners' houses - but the documents themselves can be perceived as "a microcosm of cultural transfer. ${ }^{10}$ Charters were a space of contact and encounter in which Jews visibly participated: as addressees, as witnesses, subsumed under "honourable and pious people «, ${ }^{11}$ and also as issuers. These charters, mostly issued for the respective Christian business partner, were a space of Jewish-Christian encounter in itself: in (rarely) Latin or German, written, perhaps, by a Christian scribe ${ }^{12}$ but often with the Jew's (or Jewess's) signature in Hebrew; whereas Jewish moneylenders often added Hebrew notes to the debenture bonds handed over to them by their Christian debtor. Charters issued by both Jews and Christians

5 Higgs Strickland, Saracens, Demons and Jews; Wiedl, Laughing at the Beast.

6 Wiedl, Host on the Doorstep, on the priest's conspiracy 321-322; Merback, Pilgrimage and Pogrom, 72, 77-78, 129, 177

7 See, for the Holy Roman Empire, the steadily growing database www.medieval-ashkenaz.org (retrieved on 11 November 2017), maintained by the project Corpus der Quellen zur Geschichte der Juden im spätmittelalterlichen Reich at the Arye Maimon-Institut für Geschichte der Juden at the University of Trier; for Austria, see the ongoing project Documents on Jewish History in Medieval Austria, www.injoest.ac.at/en/projects/projects-in-progress/ medieval-jewish-documents/medieval-jewish-documents.html (retrieved on 11 November 2017, with download links to the volumes already published).

8 Maya Soifer Irish has presented fascinating in-depth research on the anti-Jewish sentiments expressed in the petitions to the cortes of Northern Castile, see Soifer Irish, Jews and Christians in Medieval Castile, 221-261.

9 For a summary of approaches, see Arndt and Hedwig, Visualisierte Kommunikation im Mittelalter. Two contributions by Irmgard Fees on charters as »key to cultural history « and graphic symbols are currently in print.

10 Keil, Jewish Business Contracts, 357.

11 Brugger and Wiedl, »... und ander frume leute genuch«, 295; Wiedl, Do hiezen sie der Juden mesner ruefen, 446-447.

12 Such as the town scribe of Klosterneuburg, Seifried Steck, who wrote several charters for Jewish customers, e.g. Archives of the Monastery of Klosterneuburg, Uk. 1388 VII 19; forthcoming: Brugger and Wiedl, Regesten 4, no. 1895 . 
were a model example of shared space, such as the charters of Count Ulrich of Celje and the Jew Isserlein of Korneuburg, who, acting as ducal arbitrators, not only issued their verdicts in both of their names but showed the shared space in their respective corroboration: with the Count's pending seal and the Jew's Hebrew signature next to each other. ${ }^{13}$

A shared space then, and space for occasional flattery - and every now and then, in the Hebrew notes, there is space for jibes against the Christian business partner: Christian feast days were characterized as "cursed" or »impure«, and two Jewish brothers from Vienna referred to the female part of their debtors as "quiver «, and perhaps shared a smile over the joke that only fellow Jews would be able to read, and thus understand. ${ }^{14}$ Such remarks vacillating between general polemics and (personal) slander are rare in Jewish documents and, at first glance, seem to be missing completely from their Christian counterparts. ${ }^{15}$

Perhaps, one might argue, it was not necessary to insert gibes and quips into business charters, since anti-Jewish sentiment and polemical thoughts were expressed and propagandised openly by word and image anyway. Perhaps our first and foremost question must be the potential audience - a limited one for sure, even including the public reading and publishing of some charters, if compared with the unlimited accessibility of a Judensau, or widely audible preaching. ${ }^{16}$ But then, is this the right question to ask? Wouldn't it be even more significant if theologically founded anti-Jewish polemics made it into documents that neither focus on religious topics nor address a broader public, were in many cases not even read in public, yet were there to plant the seeds or, even more likely, trigger existing memories?

Bishop Johann's reverence to David Steuss was supposedly owed to the favour the bishop needed from his Jewish business partner. Another Jewish loan triggered a completely different reaction: his predecessor in the seat of Gurk, Paul of Jägerndorf, had left the bishopric in financial tatters, as he had sold and mortgaged mensal revenues and church property, had taken out loans with Jewish creditors, and had pawned a mitre and a crozier to Jews and subsequently neglected to redeem them. Although common practice, the pawning of church property was frowned upon by ecclesiastical law, regardless of the pawnbroker's faith. ${ }^{17}$ Hardship and dire need were the only excusable reasons for giving away even surplus

13 Brugger and Wiedl, Regesten 3, 36-38, nos. 1191-1192, nos. 1194-1195, 49-52, no. 1215, nos. 1217-1218. On the theory of Isserlein bearing a seal himself, but not using it in this context, see Keil, Jewish Business Contacts, 359-361.

14 Yuval, Christliche Symbolik, 95 (Cursed Thursday for Maundy Thursday), Keil, Jewish Business Contacts, 362 (Impure James); Keil, "...und seinem Köcher Anglis«, 113-114; on the image of the male "arrow« in rabbinic literature see Goldin, Jewish Women, 122. Israel Yuval has stated how "surprisingly similar « the language was in which Jews and Christians express their mutual hostility (Yuval, Christliche Symbolik, 87), and from the growing research on Jewish anti-Christian polemics, namely the Toledot Yeshu, the findings of Cuffel, Between Epic Entertainment and Polemica Exegesis, are particularly interesting in their connection of the characterisation of Jesus in the Toledot with Christian anti-Islamic polemics.

15 On the difference between polemics and defamation/slander, see Przybilski, Zwei Beispiele antichristlicher Polemik, 254-255, who sees defamation as aiming at destroying the other, the alien, while polemics primarily serve self-affirming purposes for which the other is used as a foil.

16 On the accessibility of the Judensau sculptures, see Wiedl, Laughing at the Beast, 339, 342; on the audience of (Dominican) preaching see Cluse, Jewish Moneylending in Dominican Preaching, 196-197.

17 See Shatzmiller, Cultural Exchange, 22-44; Müller, Zur Verpfändung sakraler Kultgegenstände; Wiedl, Sacred Objects in Jewish Hands. 
church articles, and severe restrictions applied when handing over those items. ${ }^{18}$ Although high medieval church law focussed on Christian recipients of those pawns, many theologians condemned the idea of Jews coming into possession of sacred church objects, lacing it with anti-Jewish sentiments from the sixth century onwards. Jews were suspected of deliberately maltreating these objects in lieu of Christ, and scorching criticism was poured upon the "unjust and diabolic law « [i.e. the Statute of the Market] ${ }^{19}$ that rewarded Jews for actions for which Christians were hanged. ${ }^{20}$ While municipal legislation concerned itself mainly with the question of which objects to allow as pawns, ${ }^{21}$ legal codes such as the Sachsenspiegel emphasised the unjust advantage of the Jews and added visual stimuli: in several copies of the Sachsenspiegel, a Jew is shown being punished (hanged, or with his hand chopped off), with a chalice standing next to him, making his crime evident. ${ }^{22}$

Therefore, Johann had ample legal grounds to seek both ducal and papal intervention to get these treasured items back. Pope Innocent VI's order corresponded to Johann's wishes: Paul of Jägerndorf had to immediately restore the church's sacred objects. Although the pope's main target was clearly the recalcitrant bishop, three words are quite revealing: the mitre and crozier had been pawned sub usurarum voragine to "certain Jews. " The use of this particular phrase was by no means coincidental. With the same words, usurarum voraginem, the Second Council of Lyon of 1274 had headed its constitution 26 that called for an expulsion of foreign moneylenders. ${ }^{23}$ The condemnation of the Jews as rapacious, voracious and merciless, and the image of them preying on Christians to - literally - capitalize on their plights, and threw to throw them into the abyss of usury, already had a longstanding tradition. Greed and avarice were linked to Jews in the early church scriptures already, and usury as an accusation against both Jews and Christians had increased from the twelfth century onward. ${ }^{24}$ With Lateran III, ecclesiastical critique of moneylending and usury gained momentum, with the Jews' interest rates being labelled "grave and immoderate." Criticizing Jewish moneylenders was utilised as a means to target secular rulers - among them the Austrian Duke Rudolph III, whose prevention of persecution of the Viennese Jews in 1306 was inter-

18 E.g. by melting down the items and giving away only the value of the metal, see Müller, Verpfändung sakraler Kultgegenstände, 183.

19 On the Statute of the Market (Marktschutzrecht) see below.

20 Peter the Venerable, see Schreckenberg, Christliche Adversus-Judaeos-Texte (11.-13. Jh.), 180-196; in the context of the pawning of church objects, see Magin, "Wie es umb der iuden recht stet", 361-362.

21 See Magin, "Wie es umb der iuden recht stet", particularly (but not exclusively) the chapter on the Statute of the Market, 52-99, for banned items 391-399; for Austria, Wiedl, Codifying Jews, 210-213

22 E.g. the Heidelberger Sachsenspiegel, UB Heidelberg, Cod. Pal. germ. 164, fol. 13v, digi.ub.uni-heidelberg.de/ diglit/cpg164/o040; see Magin, "Wie es umb der iuden recht stet", 55; Shatzmiller, Cultural Exchange, 37-38; Wenninger, Juden in den Bilderhandschriften, 12-14.

23 See Dorin, "Once the Jews have been Expelled«, and idem, Canon law; for an overview Cluse, Zum Zusammenhang von Wuchervorwurf.

24 Cluse, Zum Zusammenhang von Wuchervorwurf, 137-139. The phrase sub usurarum voraginem was also used in charters without Jewish involvement, e.g. in context with debt-ridden monasteries, see Municipal Archives Mainz, U /1276 Dezember, www.deutsche-digitale-bibliothek.de/item/P223HEONYIJ276AUBFTXELGZBYUARMUR (retrieved on 11 November 2017). 
preted as a means to further profit from their usury. ${ }^{25}$ Thirteenth-century chroniclers such as Peter of Zittau contributed to the spread of the image of the Jewish usurer. In his Chronicon Aulae regiae, Peter painted a dramatic picture of the plights suffered by the monks of the Bohemian monastery of Sedlec during the famine of 1280/81: eventually, their only way to avert starvation was to give away in pawn the very last of their church valuables to the Jews sub usurarum voragine. ${ }^{26}$

The reference must undoubtedly have resonated with the addressee of the papal order, Ludovico della Torre, successful candidate for the Patriarchy of Aquileia against Paul of Jägerndorf, who was being commissioned not only with making sure that Paul returned said objects but with a general examination of Paul's financial conduct. ${ }^{27}$ The disputed legitimacy of the pawning and Paul's refusal to redeem any of the pawned and mortgaged objects and revenues were to be the main focus of the investigation, yet the almost offhand reference subtly shifted at least part of the blame towards Paul's Jewish creditors. ${ }^{28}$

Surprisingly, neither mitre nor crozier were mentioned during the further process that also involved the Austrian dukes and the Counts of Celje - perhaps the two objects had indeed been returned or had, however valuable and representative, paled against the looting Paul had performed: not only had revenues been mortgaged, but castles, villages, houses, and fortifications had been sold, and even silverware, household items, and garments were missing and had to be retrieved from Paul's various households. Yet, his indebtedness to Jewish moneylenders was indeed considerable - 12,451 florins, in capital alone - for which the Austrian dukes offered compromises that not only contained no anti-Jewish remarks but made sure that the moneylenders, among them some of the wealthiest Jews of the Habsburg territories, were not subjected to too heavy losses. Also the final legal opinion of the papal investigation held Paul solely accountable for the financial losses since he had failed to seek the sanction of his superior and the consent of his canons prior to selling, mortgaging, and pawning any church property. ${ }^{29}$

25 See the examples quoted by Treue, Schlechte und gute Christen, 110-112); Cluse, Zum Zusammenhang von Wuchervorwurf, 142-144; on Rudolph III, see Wiedl, Host on the Doorstep, 318-320; on similar accusations to the early Habsburgs, see Brugger, Minem herren dem hertzogen sein juden, 746-747.

26 Emler, Fontes Rerum Bohemicarum 4, 18.

27 Wiedl, Sacred Objects, 66; Acta Salzburgo-Aquilejensia, ed. Lang, 498, no. 686.

28 References to older papal legislation also appeared in secular contexts, such as the (theological) servitus iudeorum, the perpetual servitude of the Jews due to their »sins « that appeared in secular bans of Jews from public offices, in Austria for the first time in Emperor Frederic II's town statue for Vienna from 1237, and was repeated by King Rudolph I and Duke (later King) Albrecht I upon the reissuance in 1278 and 1296 respectively, see Brugger and Wiedl, Regesten 1, 28-29, no. 17, 76, no. 60, 93-94, no. 88. This concept is not to be confused with what is referred to as "Kammerknechtschaft", the political claim of the Emperor (and territorial princes) to include the Jews in their treasury, see Abulafia, King and the Jews; and Abulafia, Christian-Jewish Relations, on the 1237 statute and its relation to Frederic's privilege 52. The ban from public office goes back to canon 14 of the Third Council of Toledo (589) and was repeated in canon 69 of Lateran IV, see Schreckenberg, Christliche Adversus-Judaeos-Texte (11.-13. Jh.), 425-426.

29 Wiedl, Sacred Objects, 68. 
A minor remark, therefore, in a series of lawsuits, orders, demands, and compromises, perhaps noteworthy yet hardly meriting, or allowing for, in-depth speculation about antiJewish polemics against usury being slipped into legal and economic considerations? Almost twenty years later, in August 1379, after the death of Johann's successor to the seat of Gurk, Johann (III) of Töckheim, two clerics presented the catalogue of the late bishop's legacy to the papal emissary: no more than 400 florins, the bishop's steward lamented, had his superior been able to leave behind, despite his honest efforts. The list of the bishop's financial burdens was long, yet according to his steward, there was only one reason for the descent into the abyss: even all the revenues of the whole bishopric together had not been enough to pay the unduly high interest demands of the Jews; and only through the aid of the Austrian dukes (perhaps a reference to their intervention twenty years earlier) had misery been averted. ${ }^{30}$

This drastic imagery is no invention of the bishop's steward: in 1282, Bishop Lutolf of Naumburg had, when declaring the sale of several properties of the bishopric, explained these transactions by what seems an almost identical reasoning - the church's revenues were not enough to cover his predecessor's debts that still kept increasing on a daily basis, and without help, the church would be swallowed up by the Jews' vortex of usury (apud judeos absorbebamur usuram voragine). ${ }^{31}$

The assignments of guilt were enhanced by anonymising the (existing) Jewish moneylenders. Bishop Paul's and both Johanns' creditors were known and appear by name in various documents. However, even if - one might argue - these documents were not available to the clerics present, at least one person must have known: the bishop's steward, Hans Payer, who had not only been closely involved with the bishopric's administration for almost twenty years but had actually stood surety for some of the bishops' Jewish credits. ${ }^{32}$ Thus, he could have easily added at least some of their names to his lament. Yet, in contrast to the usually quite precise declarations and listings of business charters, in its use of anonymity the rendering resembles theological polemics, which aim at de-personalising their statements to make them as universally applicable as possible. In this context, it is important to remember that both mentions, however offhand, of the Jews' usury were done in a (partly)

30 Brugger and Wiedl, Regesten 3, 290-291, no. 1624.

31 Von Werra und Leine bis zum Bober. Quellen zur Geschichte der Juden in Thüringen und Sachsen, TWo1, Nr. 24, ed. Maike Lämmerhirt. Retrieved 23 February 2018: www.medieval-ashkenaz.org/TWo1/TW-c1-0037.html.For further examples, see Quellen zur Geschichte der Juden im Bistum Würzburg (1273-1347), WBo1, no. 88, and WBo1, no. 55, ed Bernhard Kreuz. Retrieved 26 February 2018: www.medieval-ashkenaz.org/WBo1/WB-c1-ooob.html, www.medieval-ashkenaz.org/WBo1/WB-c1-002t.html; and Quellen zur Geschichte der Reichsstadt Rothenburg o. d. Tauber (1273-1347), RO01, no. 15, ed. Claudia Steffes-Maus. Retrieved 26 February 2018: www.medievalashkenaz.org/RO01/CP1-c1-0098.html. An interesting example is the charter of Abbess Greda and the nunnery of Altmünster (Mainz), who declared their monastery heavily encumbered with Jews and Christians, but apply the phrase only to a single Jew, the Maguntian citizen Isaac Rotbacke, see Quellen zur Geschichte der Juden im Erzbistum Mainz (1348-1390) MZo2, no. 436a, ed. Gerd Mentgen. Retrieved 26 February 2018: www.medieval-ashkenaz. org/MZ02/MZ-c1-oofv.html, whereas the Teutonic order at Freiburg attributed their immense debts, the mounting pressure and the "abyss of usury " to their creditors in general, see Quellen zur Geschichte der Juden im Elsass (1273-1347), EL01, no. 33, ed. Gerd Mentgen. Retrieved 26 February 2018: www.medieval-ashkenaz.org/EL01/ CP1-c1-02co.html.

32 Brugger and Wiedl, Regesten 3, 53, no. 1221. 
ecclesiastical context and therefore must have resonated with at least some among those who were present - and the character of the documents in question, the papal order and the catalogue of the legacy, suggest a public presentation and thus quite a large audience.

These few examples already show that tracing anti-Jewish sentiment in business documents can be tricky. Formulaic phrases such as sub usurarium voragine clearly have an antiJewish ring to them which might still resonate with the audience when applied to non-Jewish loans. Clauses such as the order to resell or release vineyards only to Christians and never to Jews that several Austrian and Bavarian monasteries and clergymen introduced into their sale deeds from the mid-fourteenth century onwards might reflect an actual fear of losing their property in the event of an unredeemed pledge, ${ }^{33}$ yet (wilfully) ignore the very real possibility of Christian moneylending and pawnbroking. In other economic sources, antiJewish stances are expressed more blatantly. In their struggle to gain control over the Jews living within their walls, cities focussed on the Jews' legal standing and economic activities; and it is therefore not surprising that these subjects play a key role in municipal anti-Jewish expressions. Since the cursed Jews have much better rights towards the Christians than the Christians towards the Jews, a paragraph of the Viennese Stadtrechtsbuch, a privately commissioned compendium of legal regulations from before 1360, describes the legal situation regarding stolen pawns. While its other, extensive regulations on business transactions and pawnbroking that concern both Jews and Christians remain quite impartial in their phrasing, the author lashes out against the same law, the Statute of the Market, that Peter the Venerable had stigmatised as the "very old but truly diabolic law « that allowed Jews to »be fattened and revel in luxury « in the early twelfth century. ${ }^{34}$ The Statute, the right of the Jews to clear themselves of the suspicion of having accepted stolen goods as pledges by taking an oath, had in the tradition of the imperial regulations from the late eleventh century been given to the Jewish inhabitants by most territorial rulers of the Holy Roman Empire. ${ }^{35}$ Over time, it had developed into a bone of contention, particularly between rulers and cities, on an economic level, with the latter seeking to abolish or at least curtail it. Lawful it might be, the Viennese Stadtrechtsbuch therefore conceded, yet not proper and fair. The Christian pawnbroker is identified as the innocent businessman, and the author follows Peter of Zittau (and many others) in the emotional stress he puts into the image: Christian pawnbrokers, such as innkeepers or grocers, ran the risk of having to return any pledge that had been stolen beforehand, meaning that »the poor man [would] lose his pennies he had borrowed on the pledge" (hat der arm man sein phenning verlorn, die er auf die phant geparigt hat). The pitiful image is not only contrasted with the indifference of the Jews (duncht des die juden nicht), the author even ascribes an actively negative role to them: the Christian pawnbroker simply

33 In a settlement over levies and endowments, the parish of Chorherren forbade the pawning or selling of vineyards to Jews with the explicit argument that "much has been lost to the aforementioned church already (Archives of the Diocese of St. Pölten, I/03-05/02 Pfarr- und Klosterakten - Chorherrn 1, 1393; forthcoming: Brugger and Wiedl, Regesten 4, no. 2035). On the prohibition, see Brugger, Smoke in the Chapel, 84.

34 Schreckenberg, Christliche Adversus-Judaeos-Texte (11.-13. Jh.), 180-196.

35 For the ample discussion on the topic, see the overview by Magin, "Wie es umb der iuden recht stet«, 352-400. 
"had « the pledges in his possession, while pledges of Jewish pawnbrokers were in eines juden gewalt vervangen, "caught up in the Jew's power, " adding a sense of aggression to the perceived economic injustice. It might be far-fetched to associate this half-sentence with images of Jews as predators such as hyenas and manticors, ${ }^{36}$ and it is questionable whether the scribe of the Viennese Stadtrechtsbuch had ever seen such depictions, but his phrasing does conjure up visions of the Jewish aggressor who sinks his talons into the Christian prey. The chronicle of the monastery of Klosterneuburg, about fifteen kilometres upstream from the Viennese city centre, reflects a similar image when commenting on the fire that ravaged the Jewish quarter of Vienna in 1406: however horrible the fire might have been, it had impoverished more Christians than Jews. The Christians had lost their pledges, kept in the burnt-down houses of the Jews, while, implicitly, the Jews still could, or would, demand their loans back, ${ }^{37}$ thus portraying the Jews as still being able to benefit from Christian misery.

Usury and unjust legal status were two of the most prominent anti-Jewish tropes that were raised; in the course of the fourteenth century, with the growing importance of written and corroborated documents in everyday business, another economy-based stereotype was added: that of Jews as counterfeiters of seals and charters. Several processes were conducted against Jews and ended in death sentences, and eviction decrees of the late fifteenth century, such as the eviction of the Styrian Jews in 1498, included forgery in the list of "Jewish crimes $" .^{38}$ The first time this accusation had been raised in Austria was in the introduction to the Judenbuch of Duke Albrecht II, established in 1340. Written by a clerical notary, it utilises extremely hostile rhetoric: in the past, the perfidy (infamia) of the Jews, particularly their counterfeiting of charters and seals, had caused harm of and dispute between Christians, playing upon the image of the Jews as the wilful instigator of disaster and distress, but when it had been brought to the attention of the Duke, he commanded the extirpation of said perfidy and sought to prevent any further detriment by instituting two notaries who were to record all future business transactions. ${ }^{39}$

The recording of Jewish business transactions, either in commonly used ledgers or in separate Judenbücher,$^{40}$ in addition to the issuance of a charter, were quite customary and, at least sometimes, were authorised by ducal permission..$^{41}$ While the Judenbücher were primarily a means of control over Jewish (business) activities, they could also serve as a safeguard for the Jews against accusations since they could present these ledgers before court. ${ }^{42}$ The

36 Higgs Strickland, Saracens, Demons and Jews, 136-137 (manticore), 153 (hyena).

37 Stowasser, Zur Geschichte der Wiener Geserah, 117.

38 Lehnertz, Judensiegel im spätmittelalterlichen Reichsgebiet, 183-185; Keil, Regensburger Judensiegel, 139-140.

39 See the detailed analysis by Haverkamp, Verschriftlichung, 13-21.

40 Peter, Judenbücher als Quellengattung; for Austria Wiedl, Juden in österreichischen seriellen Quellen, 140-142.

41 Ducal permission is transmitted for the Lower Austrian town of Bruck an der Leitha: in 1388, Duke Albrecht III permitted the town to set up a ledger »in the custom of our other towns « in which all loans from Jews to Christians should be recorded (Municipal Archives of Bruck an der Leitha, Urk. no. 27; forthcoming: Brugger and Wiedl, Regesten 4, no. 1886).

42 Wiedl, ... und kam der Jud, 252-253. 
introductions of other Austrian (still existing) Judenbücher could not be any more different to the one in Albrecht's Judenbuch: hie hebt sich an das judenpuech, "here begins the Jews' book ", is the caption of the Judenbuch of the Viennese Scheffstrasse, actually the middle of a three-part Grund- and Satzbuch (title and mortgage register). ${ }^{43}$ All three parts are accompanied by a drawing: a crown (as a symbol for the Scheffstrasse being owned by the duchess of Austria), a Christian, and a Jew. While the Christian remains anonymous, the Jew, with a Jewish hat and an axe that might signify judicial power, has maister Lesyr in parenthesis above his head, perhaps a fictitious person, but perhaps identifying the drawing with an actual individual from the Jewish community. Despite the stereotypical Jewish hat that marks Lesir as a Jew, the drawing shows none of the vituperation so visible in another depiction of Jews in an economic source: the infamous rendition of the Norwich Jews Isaac, Mosse-Mokke and Abigail in the tallage-rolls of $1233,{ }^{44}$ whose usage of grotesque facial features and surrounding demons caused Anthony Bale to literally use it as a depiction of his definition of medieval anti-Semitism. ${ }^{45}$

Neither of the Austrian Judenbücher contains any kind of anti-Jewish entry, which makes the introduction of the ducal Judenbuch, and particularly the prayer it closes with, all the more puzzling. The invocations of the prayer to Christ and Mary for protection against the Jewish evildoers take anti-Jewish sentiment far beyond the economic context of allegedly counterfeited charters and seals and bear a strong resemblance to later anti-Jewish sermons from the Viennese theological faculty. Unfortunately, when trying to analyse the source itself one is faced with a major problem: the ducal Judenbuch has not survived. The date and circumstance of its loss are unknown, and the introduction is only transmitted in a transcript from the eighteenth century. Only a rather vague description of (presumably) the original codex exists, from the sixteenth-century archivist Wilhelm Putsch with whom at least the introduction resonated so much that he included it in his short description: the ledger had been established damit sy die Cristen mit den falschen siglen nit mer betriegen, "so that they would not be able to further betray the Christians with their false/counterfeited seals « ${ }^{46}$ However, no conclusions can be drawn as to how long, or how extensively it had been used, and what regions it actually managed to cover. Unlike other (existing and lost) Judenbücher which are mentioned with increasing frequency in business charters from the mid-fourteenth century onwards, the ducal Judenbuch is conspicuously absent from other source material. ${ }^{47}$

43 Austrian State Archives, FHKA AHK VDA Urbare 1067A und B, 1068, the drawings on fol. 1r (crown), fol. 38r (Christian) and fol. 109r (Jew). The Judenbuch of Wiener Neustadt, like the Viennese one part of a larger manuscript that contained mortgage and title registers and testaments, and the Judenbuch of the monastery of Rein, both 15th century, have similar headers, see Keil, Liber Judeorum von Wiener Neustadt, and Herzog, "Juden-Puech" des Stiftes Rein.

44 The cartoon (British National Archives, Kew, E.410/1565, Rolls of the Issues of the Exchequer, Hilary Term 1233) can be seen here: www.nationalarchives.gov.uk/education/resources/medieval-mystery/ (retrieved on 11 November 2017); it is used (under the header "A medieval mystery«) in the "Classroom courses« of the National Archives.

45 Bale, Jew in the Medieval Book, 2-4.

46 Stowasser, Zur Geschichte der Wiener Gesera, 110.

47 Only in 1386, in a charter of Jörg of Liechtenstein-Nikolsburg, ducal Kammermeister, that records the transfer property rights to the Jew Lesir of an unredeemed estate, it is mentioned that the pawning of the estate had been recorded in the Judenbuch (Brugger and Wiedl, Regesten 3, 405, no. 1830). It is, however, not clear whether this refers to the ducal Judenbuch or the Judenbuch of the city of Vienna (where Lesir lived) that had been established in 1372. 
Nevertheless, the introduction with its vicious anti-Jewish rhetoric is quite unique in the context of Austrian business sources. A closer look at the ruling duke and the surrounding political events however does not contribute to any clarification; on the contrary: the strong protection Duke Albrecht II, the fautor iudeorum of the Calendarium Zwettlense, had provided for the Jews has led to speculation whether the Judenbuch had actually been planned as a further means of security for the Jews, particularly after the wide-ranging pogroms of $1338 .{ }^{48}$

Other economic source materials from that period dealing with seal-cutting do not yield any clues about anti-Jewish sentiment, and remain silent on the accusation of Jews counterfeiting seals, most notably the 1366 code of the guild of the Viennese goldsmiths that regulated the cutting of seals. The code's safety precautions forbade the cutting of seals in places that were considered suspicious, yet while these places included under den juden, "among the Jews", they also listed any Christian house (meaning the rooms inside) or "secret chambers". Also, in production and possession no difference was made between Jews and Christians: neither goldsmiths nor anyone else, be he priest, layman, or Jew, was allowed to cut a seal without prior and secure knowledge of its legitimacy, and any illegally obtained seal had to be destroyed, whether it had belonged to a Christian or a Jew. ${ }^{49}$ References to Jews allegedly forging charters and seals are also missing from the period's historiography. The only actual mention of (again, alleged) Jewish counterfeit stems from the ducal Fronbuch, where to the Siegelverruf (the official invalidation of lost or destroyed seals) of a Viennese citizen the note was added: und daz sein ze dem ersten mal, daz under den juden gefelscht ist worden, "and this was the first time that there had been counterfeiting among the Jews. " ${ }^{0}$

Accusations of unjust interest rates and of counterfeited seals and charters seem almost custom-made for mocking remarks in business charters. Business charters deal aplenty with lost, stolen or invalid seals, and even more often with charters that had been lost by either the Christian debtor or the Jewish creditor, ${ }^{51}$ yet in the sources that resulted from daily JewishChristian interaction, there seems to be no indication that the persisting stereotypes that were being reinforced in the people's minds by narratives and images somehow reverberated in the phrasing of these documents.

48 Haverkamp, Verschriftlichung, 31; Brugger, ...hat ein hebraisch zettel dabey, 427-428.

49 Brugger and Wiedl, Regesten 3, 27, no. 1174. Lost or stolen seals were considered a serious matter; when, e.g., in 1404, the seal of the long-dead Reinprecht of Ebersdorf reappeared in the possession of a goldsmith, it was confiscated by the masters of the mint and declared invalid by Duke Albrecht IV, who had this message sent to all Christian and Jewish business partners (Archives of the Province of Lower Austria, NÖLA, Urkunden des Ständischen Archivs, no. 1616; forthcoming: Brugger and Wiedl, Regesten 4, no. 2294).

50 A register of lawsuits conducted by the nobility and monasteries before the ducal court (Hoftaiding) between 1386 and 1397, Austrian State Archives, HHStA, Hs. Weiß 18, fol 36v (1388); a term later, the citizen again declared his and his father's seal void, with the addition that this was ze dem andern mal (for the second time) that there had been counterfeiting (fol. 41r). Invalidation of seals was a quite common occurrence, and since it often concerned Jewish business partners, many of these proclamations were done in front of Christian courts and synagogues, see Wiedl, Do hiezen si der Juden mesner ruefen, 440-441.

51 Brugger, ...hat ein hebraisch zettel dabey, 426-427. 
Perhaps we need to take an even closer look. In 1368, the mayor, town judge and city council of the small Lower Austrian town of Hainburg, about 50 kilometres downstream from the city centre of Vienna, were involved in a conflict which the citizens of the nearby Hungarian town of Pressburg/Bratislava had with their Jews. As a consequence of the (shortterm) expulsion of the Hungarian Jews under King Louis I around 1360, the Jews of Bratislava had relocated to Hainburg from where they tried to collect the outstanding debts of the Bratislava citizenry. To be able to enforce their claims, they had to present their debenture bonds to the Hainburg iudex iudeorum (the Christian "Judge for the Jews") and the town judge of Bratislava within a year, and the latter would corroborate them with his seal. On first impression, this seems to conform to a quite common procedure - both the presentation of debt instruments and pledges to a municipal authority and the corroboration of business documents by a town official was mandatory in many cities..$^{52}$ The Bratislava Jews however had not only to hand over their documents for sealing: they remained in the possession of the Bratislava town judge, wan man die urchund und brief in der Juden gewalt nicht lazzen wolt und in der auch nicht getrawn wolt, "since one doesn't want to leave the documents in the power of the Jews and would not want to trust them. « Suspicion of a potential manipulation of the charters, of a presentation of illegal debt instruments, and ultimately of illegally obtained financial gain and betrayal of Christians on part of the Jews is clearly implied, regardless of the fact that their weaker position had just led to their expulsion. ${ }^{53}$

In the confined space of medieval towns, Jews and Christians lived in close proximity. Apart from being sources that pay witness to everyday meetings, court documents that show Jews as both plaintiffs and defendants attest to the acquaintance of Jews with the legal systems of towns, counties, and ruling courts. While Jews were, in theory, direct subjects to the respective ruler and could claim jurisdiction before his court, and while in some cases, intervention from the dukes or their representatives can be traced, ${ }^{54}$ the majority of cases were dealt with before the court that was responsible, be it the town's Bürgerschranne, the court of an ecclesiastical institution, or of a particular vineyard (Berggericht). The lawsuits deal with issues of moneylending and pawnbroking as much as with everyday quarrels between neighbours - houses or sheds that were built too high or too close, construction defects such as crumbling walls or overflowing rainwater drains that endangered the adjacent property, in both cause and procedure similar to disputes between Christian neighbours, and often subjected to municipal regulations. Expressions of mistrust and a certain reluctance to share the same space, however, can be traced on both sides - Benjamin Laqua has pointed out the significance of the Jew Joseph of Ahrweiler's wish to brick up and relocate a window in his house through which he had the neighbouring chapel in direct line of sight, echoing the twelfth/thirteenth-century Sefer Hasidim that called for shading or walling up windows that forced Jewish inhabitants to look upon the crucifixes of adjacent churches. ${ }^{55}$ The (in)visibility

52 Wiedl, Codifying Jews, 217.

53 Brugger and Wiedl, Regesten 3, 71-72, no. 1253. It has been doubted that there had been any expulsion of the Hungarian Jews under Louis I, the 1368 charter, however, is one of the (few) sources that give evidence of such an expulsion, see also the comment to no. 1253 .

54 Wiedl, ...und kam der jud, 246-247.

55 Laqua, Nähe und Distanz, 83-85, on the Sefer Hasidim concerning windows see also Mikosch, Zeichen, Bilder, Codes, 43-44. 
of his Jewish neighbours, and the closing off of his Christian space from Jewish eyes might have been the reason for the Viennese citizen Peter Püchler to demand of the Viennese Jew David Steuss, to whom he had sold a part of his house in 1372, that David should be obliged to not only erect a separation wall but also brick up all existing windows, doors, and skylights that faced Püchler's garden. ${ }^{56}$ Similar wishes of an obstructed view presumably prompted the Teutonic Knights of Vienna to demanded that their Jewish neighbour, Hessmann, with whom they quarrelled over the reconstruction of their courtyard between the two houses, should not be allowed to have, or build in, any windows that led into the courtyard. ${ }^{57}$ While these demands might have been rooted in desires for limited visibility of and for Jews and the establishing of exclusive Christian (and Jewish) spaces, such regulations are not specific to conflicts between Jewish and Christian neighbours but appear as matters of dispute between Christian neighbours as well..$^{8}$

Jewish presence was noticeable beyond the visual - sounds of prayers and the shofar were audible on the streets and in close-by buildings. The Sackcloth Friars of 1270's London had felt so annoyed by the neighbouring Jews' "continuous wailing from the synagogue" (per ipsorum iudeorum continuum ululatum in eadem scola) that they pleaded with King Henry III to relocate the Jews' centre of community and rededicate the former synagogue as a chapel for them; and the fifteenth-century German author Michael Beheim thought (or pretended) to hear "wailing, hellish cries, and dogs' barks" from the synagogue. ${ }^{59}$ Alleged foul and unhealthy smells that wafted from the newly installed windows of Jewish houses in early fourteenth-century Gerona caused protest among the churchgoers of the nearby church so that the windows had to be bricked up again; it is, considering how much stench was a constant in a medieval city, highly questionable whether the smell alone had given rise to the Christians' aversion. ${ }^{60}$ Perhaps the chaplain of the Vienna city hall, Jakob Poll, felt similarly bothered when, in 1373, he was up in arms against the new kitchen and chimney his neighbour, the Jew Merchlein, had built. ${ }^{61}$ Smoke and kitchen smells not only wafted through Poll's house but, according to the claimant, also permeated into the most Christian of all spaces: the bad smells were noticeable in the chapel during morning service. The phrasing of the olfactory nuisance is interesting; not only smoke but aller unrainer gesmach, all sorts of unclean smells/tastes, or ungesmach, un-smell, interfered with the church service. It might very well have been a coincidence that the words used to describe the smells that wafted

56 Brugger and Wiedl, Regesten 3, 153-154, no. 1389; Wiedl, Do hiezen si der Juden mesner ruefen, 444-445.

57 Brugger and Wiedl, Regesten 3, 251, no. 1559.

58 Mikosch, Zeichen, Bilder, Codes, 45; for Vienna, see e.g. Municipal Archives of Vienna, H.A. Urk. 559 (monasterium. net/mom/AT-WStLA/HAUrk/559/charter, retrieved on 11 November 2017).

59 Andrews, Other Friars, 201; Heil, "Gottesfeinde«, 113; on the aspect of Hebrew as an unhuman language and its ridiculing, see Heil, »Gottesfeinde«, 173-74; Wiedl, Laughing at the Beast, 349-350.

60 Mikosch, Zeichen, Bilder, Codes, 44-45.

61 He had already sued Merchlein twice over overdue revenues (1351 and 1354); in 1351, Merchlein reached a compromise »by advocacy of honourable people and gentry, Christian and Jews « (durch [...] erber leut und herren christen und juden vleissziger pet willen), which had included a ducal official. In 1354, Poll got the house, which however seems to have remained in Merchlein's possession, which suggests a furthercompromise, see Brugger, Smoke in the Chapel, 87-89. 
from the Jew's kitchen were usually associated with smells from lavatories ${ }^{62}$ and served to describe unpalatable food or food unfit for human consumption. A bad, unclean smell, however, was part of an essential anti-Jewish polemical topic, both ecclesiastical and secular: the odor iudaicus or foetor iudaicus, the "Jewish stench" first appears as a trope in Roman literature, such as Martial's epigramms (4.4), and in Christian theological texts from late Antiquity onwards. ${ }^{63}$ The "Kleiner Lucidarius «, a satirical poem from late thirteenth-century Austria had, among other stereotypes such as the Jews' usury, their murdering of Christians and general maliciousness, also raised the issue of their bad smell: wê iu, verfluochte juden, wê! wie iuwer heil verklucket! / ir stinket unde bucket. The Jews' stench was linked to their ungelouben, their unbelief, for which they would eventually perish. ${ }^{64}$

The Viennese chaplain's charter alone might seem (and perhaps is) too scarce a proof for postulating any such associations. Both of the abovementioned Jews, David Steuss and Hessmann, had included the (re-)erection of a lavatory in their reconstruction plans, yet neither was met with any undue burden, or mocking jibe, and one cannot entirely dismiss the possibility that the Teutonic Knights' wish that Hessmann should clean his lavatory through his house, and not through their courtyard, was not primarily rooted in Hessmann's religious persuasion.

Yet the idea of links between Jews, bad smells, and generally something rotten and harmful lingered, and can be traced in other economic sources. The synods of Wroclaw and Vienna enforced lingering suspicions against Jewish poison in their warning not to dine with Jews or buy any nourishment from them, ${ }^{65}$ and with the mid-fourteenth century's plague, the already existing image of the Jewish well-poisoner gained momentum. ${ }^{66}$ Town legislations banned Jews from professions concerned with nourishment, and the selling of judenfleisch, "Jewish meat" to Christians underwent particularly serious scrutiny ${ }^{67}$ While many towns (and Jewish communities) took a practical approach, such as the establishment of Jewish slaughterhouses, or Jews being allowed to use Christian slaughterhouses, and many guild and town regulations merely sought to recompense the Christians butchers for their presumed lack of income since the Jews butchered the animals themselves, regulations from the southern parts of the Holy Roman Empire in particular reflected the identification of Jews with materials considered foul and harmful to Christians. ${ }^{68}$ These towns employed various

62 E.g., ungesmach und gestanckh emanated from a lavatory next to the monastery of Göttweig's Viennese court, and due to seepage into the wall the malodour was noticeable in many rooms, Archives of the Monastery of Göttweig, Urk. 1387 VIII 22 (monasterium.net/mom/AT-StiAG/GoettweigOSB/1387_VIII_22/charter, retrieved on 11 November 2017).

63 Schreckenberg, Christliche Adversus-Judaeos-Texte (11.-13. Jh.), 722; Brugger, Smoke in the Chapel, 88.

64 Brugger and Wiedl, Regesten 1, 152-154, no. 144; Schreckenberg, Christliche Adversus-Judaeos-Texte (13.-20. Jh.), $337,340-341$

65 For Wroclaw, see Schreckenberg, Christliche Adversus-Judaeos-Texte (13.-20. Jh.), 224-226; for Vienna, see Brugger and Wiedl, Regesten 1, 59-61, no. 45.

66 Heil, »Gottesfeinde", 285-299; Graus, Pest - Geissler - Judenmorde.

67 Wiedl, Codifying Jews, 216 (beer, wine). Judenfleisch has been frequently interpreted as »kosher meat« in general, but in this context the term most likely refers to the parts of the kosherly slaughtered animals the Jews were not allowed to eat, or to animals whose slaughter was not executed according to halachic rites.

68 I thank Jörn Christophersen (Trier) for his insights into the conditions of Jewish butchers in the north-eastern parts of the Empire. 
means, from physical separation by placing the Jews' booths on the very fringe of the market to forcing them to tag the proffered meat, or, if it was being sold by Christian butchers, having it presented differently. ${ }^{69}$ One of the most common measures was to allot the Jews to the municipal meat stall where the pfinnig fleisch was sold, which could mean meat from sick or injured animals but primarily referred to foul meat, meat that had gone bad (trichinous) and was thus potentially harmful when consumed. ${ }^{70}$ In addition to that, potential Christian buyers should often be alerted to what "kind of meat « they were about to purchase $;^{71}$ and in the late fourteenth and early fifteenth centuries, with the idea of the well-poisoning Jews prevailing, some towns resorted to even more drastic measures: any meat that had been touched by Jews was considered judenfleisch and thus of minor worth, or even unfit for Christian consumption. ${ }^{72}$

It is tantamount to a commonplace to state that anti-Jewish polemics played a crucial role in the frequent outbreaks of anti-Jewish violence. The citizens of Korneuburg had murdered their Jewish neighbours, with whom they had lived peacefully in close proximity, at the merest suggestion of a "Jewish crime", their indoctrination leaving little room for doubt, ${ }^{73}$ and neither of the abovementioned documents could have contributed to their conviction about the Jews' guilt. What, therefore, to make of the meagre findings in Austria's abundant economic source material? Was it strictly polemical when in 1390, the Abbot of the Cistercian monastery of Heiligenkreuz (in yet another ecclesiastical setting) distinguished the interest their subsidiary monastery of Zwettl had to pay to Jews, usura, from that to Christians, honorancia $?^{74}$ Perhaps not. While the few examples presented here might not constitute polemics in the way a theological treatise, a sermon, or a statue of a Judensau did, they can be seen as a reverberation of these ideas, affirming pre-existing stereotypes and planting further suspicion. At the very least, they served as vehicles to bring polemical triggers into fields of economy and daily encounters. By this transference and the embedding of polemical thought into the language of business routine and everyday normality, the accusations, too, read as mundane and commonplace, suggesting that "Jewish crime" was an everyday occurrence that had, likewise, to be avenged on an everyday basis.

\section{Acknowledgements:}

This work was supported by the Austrian Science Fund (FWF) under grant P28610-G28.

69 Wiedl, Codifying Jews, 214-216; for Zurich, see Gilomen, Kooperation, 177; for Munich and Ulm, see Germania Judaica III/2, ed. Maimon et al., 902, 1500.

70 This regulation was particularly common in Bavarian towns such as Burghausen, Neuötting, Landshut, and Schärding, for many of which no Jewish settlement is known, and also the Salzburg-ruled Mühldorf (with the addition of wolfpaizzig, »bitten by the wolf«), see Wiedl, Codifying Jews, 215.

71 Munich, adopted by several Bavarian towns such as Kitzbühel, Brugger and Wiedl, Regesten 2, 11, no. 1145.

72 E.g. in the town statute of Bolzano from 1437 that forbids any sale of meat that had been "controlled, touched, or slaughtered « by Jews, see comment to Brugger and Wiedl, Regesten 2, 11, no. 1145, with further literature.

73 On the possibility of doubt (three Korneuburg citizens trying to save a Jewish victim, and the head of the clerical investigation, Ambrosius of Heiligenkreuz), see Wiedl, Host on the Doorstep, 303, 317-318, 333.

74 Archives of the Monastery of Zwettl, Cod. 339, fol. 15r. (1390); forthcoming: Brugger and Wiedl, Regesten 4, no. 1950. 


\section{References}

Abulafia, Anna Sapir, Christian-Jewish Relations 1000-1300: Jews in the Service of Medieval Christendom (Harlow, 2011).

Abulafia, David, The King and the Jews - the Jews in the Ruler's Service, in: Christoph Cluse (ed.), The Jews of Europe in the Middle Ages (Tenth to Fifteenth Centuries) (Turnhout, 2004) 43-54.

Acta Salzburgo-Aquilejensia, Vol. 1: Die Urkunden über die Beziehungen der päpstlichen Kurie zur Provinz und Diözese Salzburg (mit Gurk, Chiemsee, Seckau und Lavant) in der Avignonischen Zeit: 1316-1378, ed. Alois Lang (Graz, 1903).

Andrews, Frances, The Other Friars: The Carmelite, Augustinian, Sack and Pied Friars in the Middle Ages (Woodbridge, Rochester, 2006).

Arndt, Steffen and Hedwig, Andreas (eds.), Visualisierte Kommunikation im Mittelalter. Legitimation und Repräsentation (Marburg, 2010).

Bale, Anthony, The Jew in the Medieval Book: English Antisemitisms 1350-1500, Cambridge Studies in Medieval Literature 60 (Cambridge, 2006).

Brugger, Eveline, ...hat ein hebraisch zettel dabey. Der Umgang mit jüdisch-christlichen Geschäftsurkunden in der spätmittelalterlichen Praxis, in: Ludger Lieb, Klaus Oschema and Johannes Heil (eds.), Abrahams Erbe. Konkurrenz, Konflikt und Koexistenz der Religionen im europäischen Mittelalter (Berlin, 2015) 421-436.

Brugger, Eveline, Minem herren dem hertzogen sein juden - die Beziehung der Habsburger zu »ihren« Juden im spätmittelalterlichen Österreich, in: 25. Österreichischer Historikertag. St. Pölten 2008, Tagungsbericht (St. Pölten, 2010) 742-749.

Brugger, Eveline, Smoke in the Chapel: Jews and Ecclesiastical Institutions in and around Vienna during the Fourteenth Century, in: Philippe Buc, Martha Keil and John Tolan (eds.), Jews and Christians in Medieval Europe: The Historiographical Legacy of Bernhard Blumenkranz (Turnhout, 2016) 79-94.

Brugger, Eveline, and Wiedl, Birgit, ...und ander frume leute genuch, paide christen und juden. Quellen zur christlich-jüdischen Interaktion im Spätmittelalter, in: Rolf Kießling, Stefan Rohrbacher, Peter Rauscher and Barbara Staudinger (eds.), Räume und Wege. Jüdische Geschichte im Alten Reich 1300-1800 (Berlin, 2007) 285-305.

Brugger, Eveline, and Wiedl, Birgit, Regesten zur Geschichte der Juden in Österreich, Band 1: Von den Anfängen bis 1338, Band 2: 1339-1365, Band 3: 1366-1386, Band 4: 1387-1404 (Innsbruck, 2005, 2010, 2015, 2018).

Buttaroni, Susanna, and Musiał, Stanisław (eds.), Ritualmord. Legenden in der europäischen Geschichte (Vienna, 2003).

Cluse, Christoph, Jewish Moneylending in Dominican Preaching: Some Examples from Late Medieval Germany, in: Elias H. Füllenbach and Gianfranco Miletto (eds.), Dominicans and Jews: Personalities, Conflicts, and Perspectives from the 13th to the 20th Century, Quellen und Forschungen zur Geschichte des Dominikanerordens NF 14 (Berlin, 2015) 195-230.

Cluse, Christoph, Zum Zusammenhang von Wuchervorwurf und Judenvertreibung im 13. Jahrhundert, in: Friedhelm Burgard, Alfred Haverkamp and Gerd Mentgen (eds.), Judenvertreibungen in Mittelalter und früher Neuzeit (Hannover, 1999) 135-163.

Cuffel, Alexandra, Between Epic Entertainment and Polemica Exegesis: Jesus as Antihero in Toledot Yeshu, in: Ryan Szpiech (ed.), Medieval Exegesis and Religious Difference. Commentary, Conflict, and Community in the Premodern Mediterranean (New York, 2015) 155-170. 
Dorin, Rowan, Canon Law and the Problem of Expulsion: The Origins and Interpretation of Usurarum voraginem (VI 5.5.1), Zeitschrift der Savigny-Stiftung für Rechtsgeschichte: Kanonistische Abteilung 99/1 (2013) 129-161.

Dorin, Rowan, »Once the Jews have been Expelled«: Intent and Interpretation in Late Medieval Canon Law, Law and History Review 34/2 (2016) 335-362.

Fontes Rerum Bohemicarum, Vol. 4, ed. Josef Emler (Prague, 1884).

Maimon, Ayre, Breuer, Mordechai and Guggenheim, Yacov (eds.) Germania Judaica III, Part 2: Ortschaftsartikel Mährisch-Budwitz - Zwolle (Tübingen, 1995).

Gilomen, Hans-Jörg, Kooperation und Konfrontation: Juden und Christen in den spätmittelalterlichen Städten im Gebiet der heutigen Schweiz, in: Matthias Konradt and Rainer Christoph Schwinges (eds.), Juden in ihrer Umwelt. Akkulturation des Judentums in Antike und Mittelalter (Basel, 2009) 157-227.

Goldin, Simha, Jewish Women in Europe in the Middle Ages: A Quiet Revolution (Manchester, 2011).

Graus, František, Pest - Geißler - Judenmorde. Das 14. Jahrhundert als Krisenzeit (second edition) (Göttingen, 1988).

Haverkamp, Alfred, Verschriftlichung und die Überlieferung von Quellen zur Geschichte des aschkenasischen Judentums während des späten Mittelalters: Überblick und Einsichten, in: Alfred Haverkamp and Jörg R. Müller (eds.), Verschriftlichung und Quellenüberlieferung. Beiträge zur Geschichte der Juden und der jüdisch-christlichen Beziehungen im spätmittelalterlichen Reich (13./14. Jahrhundert) (Peine, 2014) 1-64.

Heil, Johannes, "Gottesfeinde«-»Menschenfeinde». Die Vorstellung von jüdischer Weltverschwörung (13. bis 16. Jahrhundert) (Essen, 2006).

Herzog, David, Das »Juden-Puech« des Stiftes Rein, Zeitschrift des historischen Vereins für Steiermark 28 (1934) 79-146.

Higgs Strickland, Debra, Saracens, Demons, and Jews: Making Monsters in Medieval Art (Princeton, 2003).

Keil, Martha, Der Liber Judeorum von Wiener Neustadt 1453-1500. Edition, in: Martha Keil and Klaus Lohrmann (eds.), Studien zur Geschichte der Juden in Österreich (Vienna, 1994) 41-99.

Keil, Martha, Ein Regensburger Judensiegel des 13. Jahrhunderts. Zur Interpretation des Siegels des Peter bar Mosche Halewi, Aschkenas 1 (1991) 135-150.

Keil, Martha, Jewish Business Contracts from Late Medieval Austria as Crossroads of Law and Business Practice, in: John V. Tolan, Capucine Nemo-Pekelman, Nora Berend and Youna Masset (eds.), Religious Minorities in Christian, Jewish, and Muslim Law (5th-15th Centuries) (Turnhout, 2017) 353-367.

Keil, Martha, "...und seinem Köcher Anglis«. Kulturtransfer, Polemik und Humor in jüdischen Geschäftsurkunden des mittelalterlichen Österreich, in: Rotraud Ries and Markus J. Wenninger (eds.), Festschrift für Friedrich Battenberg, Aschkenas 26/1 (2016) 101-115.

Laqua, Benjamin, Nähe und Distanz. Nachbarrechtliche Regelungen zwischen Christen und Juden (12.-14. Jahrhundert), in: Sigrid Hirbodian, Christian Jörg, Sabine Klapp and Jörg R. Müller (eds.), Pro multis beneficiis. Festschrift für Friedhelm Burgard. Forschungen zur Geschichte der Juden und des Trierer Raumes (Trier, 2012) 73-92.

Lehnertz, Andreas, Judensiegel im spätmittelalterlichen Reichsgebiet. Beglaubigungstätigkeit und Selbstrepräsentation von Jüdinnen und Juden, Unpublished PhD Thesis (University of Trier, 2017).

Lotter, Friedrich, Talmudisches Recht in den Judenprivilegien Heinrichs IV.? Zu Ausbildung und Entwicklung des Marktschutzrechts im frühen und hohen Mittelalter, Archiv für Kulturgeschichte 71 (1989) 55-92. 
Magin, Christine, »Wie es umb der iuden recht stet. «Der Status der Juden in spätmittelalterlichen Rechtsbüchern (Göttingen, 1999).

Merback, Mitchell B., Pilgrimage and Pogrom: Violence, Memory and Visual Culture at the Host-Miracle Shrines of Germany and Austria (Chicago, 2013).

Mikosch, Gunnar, Zeichen, Bilder, Codes - Prolegomena zu einer Semiotik jüdischer Räume, in: Susanne Ehrich and Jörg Oberste (eds.), Städtische Räume im Mittelalter (Regensburg, 2009) 35-47.

Müller, Jörg R., Zur Verpfändung sakraler Kultgegenstände im mittelalterlichen Reich: Norm und Praxis, in: Sigrid Hirbodian, Christian Jörg, Sabine Klapp and Jörg R. Müller (eds.), "Pro multis beneficiis". Festschrift für Friedhelm Burgard. Forschungen zur Geschichte der Juden und des Trierer Raumes (Trier, 2012) 179-204.

Musílek, Martin, Juden und Christen in der Prager Altstadt während des Mittelalters. Koexistenz oder Konfrontation, in: Eva Doležalová (ed.), Juden in der mittelalterlichen Stadt/ Jews in the Medieval Town. Der städtische Raum im Mittelalter - Ort des Zusammenlebens und des Konflikts/Urban Space in the Middle Ages - A Place of Coexistence and Conflicts (Prag, 2015) 57-78.

Peter, Thomas, Judenbücher als Quellengattung und die Znaimer Judenbücher: Typologie und Forschungsstand, in: Rolf Kießling, Peter Rauscher, Stefan Rohrbacher and Barbara Staudinger (eds.), Räume und Wege. Jüdische Geschichte im Alten Reich 1300-180o (Berlin, 2007) 307-334

Przybilski, Martin, Zwei Beispiele antichristlicher Polemik in Spätantike und Mittelalter: tol'dot jeschu und nizzachon jaschan, in: Eveline Brugger and Birgit Wiedl (eds.), ein Thema - zwei Perspektiven. Juden und Christen in Mittelalter und Frühneuzeit (Innsbruck, 2007) 253-268.

Quellen zur Geschichte der Juden im Bistum Würzburg, WBo1, no. 88, and WB01, no. 55, ed. Bernhard Kreuz, in: Alfred Haverkamp and Jörg R. Müller (eds.), Corpus der Quellen zur Geschichte der Juden im spätmittelalterlichen Reich (Trier, 2015). Retrieved 26 February 2018: www.medieval-ashkenaz.org/WBo1/WB-c1-ooob.html, www.medieval-ashkenaz. org/WB01/WB-c1-002t.html.

Quellen zur Geschichte der Reichsstadt Rothenburg o. d. Tauber (1273-1347), ROo1, no. 15, ed. Claudia Steffes-Maus, in: Alfred Haverkamp and Jörg R. Müller (eds.), Corpus der Quellen zur Geschichte der Juden im spätmittelalterlichen Reich (Trier, 2015). Retrieved 26 February 2018: www.medieval-ashkenaz.org/ROo1/CP1-c1-0098.html.

Quellen zur Geschichte der Juden im Erzbistum Mainz (1348-139o), MZo2, no. 436a, ed. Gerd Mentgen, in: Alfred Haverkamp and Jörg R. Müller (eds.), Corpus der Quellen zur Geschichte der Juden im spätmittelalterlichen Reich (Trier, 2015). Retrieved 26 February 2018: www. medieval-ashkenaz.org/MZo2/MZ-c1-oofv.html.

Quellen zur Geschichte der Juden im Elsass (1273-1347), EL01, no. 33, ed. Gerd Mentgen, in: Alfred Haverkamp und Jörg R. Müller (eds.), Corpus der Quellen zur Geschichte der Juden im spätmittelalterlichen Reich (Trier, 2015). Retrieved 26 February 2018: www.medievalashkenaz.org/EL01/CP1-c1-02co.html.

Rubin, Miri, Gentile Tales: The Narrative Assault on Late Medieval Jews (second edition) (Philadelphia, 2004).

Schreckenberg, Heinz, Die christlichen Adversus-Judaeos-Texte (11.-13. Jahrhundert). Mit einer Ikonographie des Judenthemas bis zum 4. Laterankonzil (second edition), Die christlichen Adversus-Judaeos-Texte (13.-20. Jh.) (Frankfurt/Main, 1991, 1994). 
Shatzmiller, Joseph, Cultural Exchange: Jews, Christians, and Art in the Medieval Marketplace (Princeton, 2013).

Soifer Irish, Maya, Jews and Christians in Medieval Castile. Tradition, Coexistence, and Change (Washington, DC, 2016).

Stowasser, Otto H., Zur Geschichte der Wiener Geserah, Vierteljahresschrift für Sozial- und Wirtschaftsgeschichte 16 (1922) 104-118.

Treue, Wolfgang, Schlechte und gute Christen: Zur Rolle von Christen in antijüdischen Ritualmord- und Hostienschändungslegenden, Aschkenas 2/1 (1995) 95-116.

Von Werra und Leine bis zum Bober. Quellen zur Geschichte der Juden in Thüringen und Sachsen, TWo1, Nr. 24, ed. Maike Lämmerhirt, in: Alfred Haverkamp and Jörg R. Müller (eds.), Corpus der Quellen zur Geschichte der Juden im spätmittelalterlichen Reich (Trier, 2015). Retrieved 23 February 2018: www.medieval-ashkenaz.org/TW01/TW-c1-0037.html.

Wenninger, Markus, Die Juden in den Bilderhandschriften des Sachsenspiegels, in: Mark H. Gelber, Jakob Hessing and Robert Jütte (eds.), Integration und Ausgrenzung. Studien zur deutsch-jüdischen Literatur- und Kulturgeschichte von der Frühen Neuzeit bis zur Gegenwart. Festschrift für Hans Otto Horch (Tübingen, 2009) 2-18.

Wiedl, Birgit, Codifying Jews. Jews in Austrian Town Charters of the 13th and 14th Centuries, in: Merrall Price and Kristine Utterback (eds.), Slay Them Not: Jews in Medieval Christendom (Leiden, 2013) 201-222.

Wiedl, Birgit, Do hiezen si der Juden mesner ruefen. Jüdisch-christliche Geschäftsurkunden als Quellen zur Alltagsgeschichte, in: Ludger Lieb, Klaus Oschema and Johannes Heil (eds.): Abrahams Erbe. Konkurrenz, Konflikt und Koexistenz der Religionen im europäischen Mittelalter (Berlin, 2015) 437-453.

Wiedl, Birgit, Juden in österreichischen seriellen Quellen in der ersten Hälfte des 14. Jahrhunderts, in: Alfred Haverkamp and Jörg R. Müller (eds.), Verschriftlichung und Quellenüberlieferung. Beiträge zur Geschichte der Juden und der christlich-jüdischen Beziehungen im spätmittelalterlichen Reich (13./14. Jahrhundert) (Peine, 2014) 123-146.

Wiedl, Birgit, Laughing at the Beast: The Judensau. Anti-Jewish Propaganda and Humor from the Middle Ages to the Early Modern Period, in: Albrecht Classen (ed.): Laughter in the Middle Ages and Early Modern Times: Epistemology of a Fundamental Human Behavior, its Meaning, and Consequences (Berlin, 2010) 325-364.

Wiedl, Birgit, Sacred Objects in Jewish Hands: Two Case Studies, in: Philippe Buc, Martha Keil and John Tolan (eds.), Jews and Christians in Medieval Europe: The Historiographical Legacy of Bernhard Blumenkranz (Turnhout, 2016) 57-77.

Wiedl, Birgit, The Host on the Doorstep: Perpetrators, Victims, and Bystanders in an Alleged Host Desecration in Fourteenth-Century Austria, in: Albrecht Classen and Connie Scarborough (eds.), Crime and Punishment in the Middle Ages and Early Modern Age: Mental-Historical Investigations of Basic Human Problems and Social Responses (Berlin, 2012) 299-346.

Wiedl, Birgit, ... und kam der jud vor mich ze offens gericht. Juden und (städtische) Gerichtsobrigkeiten im Spätmittelalter, Mediaevistik 28 (2015/2016) 243-268.

Yuval, Israel Jacob, Christliche Symbolik und jüdische Martyrologie zur Zeit der Kreuzzüge, in: Alfred Haverkamp (ed.), Juden und Christen zur Zeit der Kreuzzüge, Konstanzer Arbeitskreis für mittelalterliche Geschichte, Vorträge und Forschungen XLVII (Sigmaringen, 1999) 87-106. 
Yuval, Israel Jakob, Das Jahr 1240: Das Ende eines jüdischen Millenniums, in: Gundula Grebner and Johannes Fried (eds.), Kulturtransfer und Hofgesellschaft im Mittelalter. Wissenskultur am sizilianischen und kastilischen Hof im 13. Jahrhundert (Berlin, 2008) 13-40.

Yuval, Israel Jakob, Juden, Hussiten und Deutsche. Nach einer hebräischen Chronik, in: Alfred Haverkamp and Franz-Josef Ziwes (eds.), Juden in der christlichen Umwelt während des späten Mittelalters (Berlin, 1992) 59-102.

\section{Manuscripts and Charters:}

Austrian State Archives

Haus-, Hof- und Staatsarchiv (HHStA)

Hs. Weiß 18, fol 36v. fol. 41r

Finanz- und Hofkammerarchiv (FHKA)

Alte Hofkammer (AHK), Niederösterreichisches Vizedomamt (VDA) Urbare 1067A (Satzbuch), B (Judenbuch), 1068 (Grundbuch), fol. 1r (crown), fol. 38r, fol. 109r

British National Archives, Kew

E.410/1565, Rolls of the Issues of the Exchequer, Hilary Term 1233

www.nationalarchives.gov.uk/education/resources/medieval-mystery/

Bruck an der Leitha, Municipal Archives

Urk. no. 27

Göttweig, Archives of the Monastery

Urk. 1387 VIII 22, monasterium.net/mom/AT-StiAG/GoettweigOSB/1387_VIII_22/charter

Heidelberg, University Library

Cod. Pal. germ. 164, Heidelberger Sachsenspiegel, fol. 13v, digi.ub.uni-heidelberg.de/diglit/ cpg164/0040

Lower Austria, Archives of the Province (NÖLA)

Urkunden des Ständischen Archivs, no. 1616

Mainz, Municipal Archives

U /1276 Dezember, www.deutsche-digitale-bibliothek.de/item/P223HEONYIJ276AUBFTXELGZBYUARMUR)

St. Pölten, Archives of the Diocese

I/03-05/02 Pfarr- und Klosterakten - Chorherrn 1, 1393

Vienna, Municipal Archives (WStLA)

Haupt-Archiv (H.A.) Urk. 559, monasterium.net/mom/AT-WStLA/HAUrk/559/charter)

Zwettl, Archives of the Monastery

Cod. 339, fol. 15r. (1390) 


\title{
Good and bad friars:
} polemical patterns and strategies between Franciscans in the early fourteenth century

\author{
Melanie Brunner*
}

This study examines the use of polemical strategies in the internal Franciscan debates during the first half of the fourteenth century, focusing on the exchanges between Ubertino of Casale and his opponents during the Spiritual crisis, and between Michael of Cesena and Gerald Odonis in the aftermath of the so-called theoretical poverty controversy. By comparing the use of polemical tropes and patterns across the two conflicts, it is possible to isolate some of the strategies used by the participants in the debates, as well as highlighting the shifting boundaries of inclusion and exclusion in the definition of what constituted a »true" Franciscan. While outsiders contributed to the debates, this article focuses particularly on the ways in which members of the Franciscan order responded to challenges posed to the authors' understanding of the Franciscan vocation by other members of the order.

All sides in these debates agreed on poverty and obedience as central values of the Franciscan life, but they did not accept that their opponents might share their regard for the order's rule and vocation. The debates therefore produced overlapping and competing visions of the Franciscan life which personalised and polarised the underlying larger issues, as well as establishing and defending the boundaries between "true» and "false" Franciscans, and thereby creating and reinforcing a sense of identity against those members of the order which fell outside the vision.

Keywords: Ubertino of Casale; Raymond de Fronsac; Michael of Cesena; Gerald Odonis; Franciscan poverty; polemics; rhetoric; papal authority; poverty controversy

The fourteenth century saw a developing discourse over what it meant to be a Franciscan. The debate about the Franciscan vow of poverty had produced a state of affairs where two of the order's fundamental virtues, poverty and obedience, came to be placed in direct conflict. The catalyst for the crisis was the question of whether, and to what extent, the vow of poverty demanded not just the renunciation of property rights, but also restrictions in the use of material goods. When the order's leadership rejected the idea that such restrictions were an integral part of the vow, adherents of this view found themselves having to decide between their vow of poverty and that of obedience. Obedience was another fundamental value for the order, both as a virtue in its own right and in its more instrumental form of

* Correspondence details: Melanie Brunner, Institute for Medieval Studies, University of Leeds, Leeds LS2 9JT. Email: M.Brunner@leeds.ac.uk. 
ensuring internal conformity and discipline. The discussion had recourse to older debates in earlier stages of Franciscan history, but there was a new urgency in the fourteenth century and the debate developed in new directions. There are a number of developments that fed into this: the escalation of the Spiritual crisis after 1300, the interventions of the papacy, and especially Pope John XXII (1316-1334), the fall-out from the Michaelist split with the papacy, and the literary activities of the dissident Franciscans in Munich in the 1330 s and beyond. ${ }^{1}$ The debate about the essence of Franciscan identity consisted of a number of overlapping and competing discussions about the nature of Franciscanism, framed especially in terms of the theory and practice of the order's poverty ideal. This was not confined to the fourteenth century and did not end with the Michaelists at the imperial court; one of the issues of scholarship on the fourteenth-century Franciscan order is that many of the developments are discussed in isolation from each other, and the strands are rarely integrated, as Sylvain Piron has pointed out in his discussion of the relationship between the Spirituals and the early Observant movement. ${ }^{2}$

A great deal was at stake in these debates: the Franciscan vocation and the salvation of all individual friars. The discussion drew on the ideas of Peter John Olivi and his critics, as well as the general summary of the Franciscan ideal in Pope Nicholas III's bull Exiit qui seminat (1279). This bull was crucial to the later development of the Spiritual crisis, and it was both an attempt to clarify the Franciscan rule regarding its content and the legal obligations it entailed for the order, as well as a defence of the Franciscan ideal against its outside critics. ${ }^{3}$ Exiit was based on a predominantly legal definition of poverty as the renunciation of property rights; it was a legal definition that did not include questions of use or consumption, and its evangelical poverty was primarily defined by a lack of possessions. ${ }^{4}$ The focus was on the renunciation of property rights, and while Nicholas III recommended moderation in the use of material goods, this was not central or essential to his definition. This concentration on the rejection of property was not enough for some Franciscans, whose most influential spokesman became the Provençal friar Petrus Johannis Olivi. Olivi had argued in his Quaestio de usu paupere (c. 1279) that moderation in the use of material goods was an integral part of the Franciscan vow because Franciscan poverty should involve material consequences in the daily life of the friars. ${ }^{5}$ The reaction of the order's leadership was overwhelmingly negative, and Olivi's theory engendered fierce opposition and caused a major crisis in the order that lasted for decades. The discussion was intense and often acrimonious, in a range of different fora, including both formal and informal debates at the curia. ${ }^{6} \mathrm{~A}$ large part of this multi-centred discussion was done in writing, however, either as part of the official papal enquiries into the state of the order, or as part of an ongoing internal argument over the Franciscan ideal.

The literature that has been generated by the debates in the Franciscan order is vast, but for a summary of the origins and development of the Spiritual crisis, see Burr, Spiritual Franciscans; on the poverty ideal, Lambert, Franciscan Poverty; and on the poverty controversy, Nold, Pope John XXII and his Franciscan Cardinal, as well as, most recently, Miethke, Theoretischer Armutsstreit. On the role of obedience in the order, see Binoy, La povertà e l'obbedienza.

2 Piron, Mouvement clandestin, 2.

3 See Lambert, Franciscan Poverty, 149-150.

4 See Condren, Rhetoric, Historiography and Political Theory, 17.

5 For a fuller discussion of Olivi, see Schlageter, Heil der Armen, and Burr, Spiritual Franciscans, especially 50-65.

6 For a summary of the curial debates, see Burr, Spiritual Franciscans, 111-158 and Lambert, Franciscan Poverty, 197-214. 
The polemical nature of many of these texts has generally been taken for granted, partly because of the use of rhetorical devices such as repetition and hyperbole, as well as personal attacks on opponents. ${ }^{7}$ More recent work on polemics in pre-modern contexts has stressed additional aspects of polemical discourse, however, including the link between polemics and intellectual violence, and the role of polemics in the establishment of an identity defined against the polemicist's opponents. ${ }^{8}$ Particularly important here is the focus on rhetorical and intellectual violence as part of polemical discourse, something which could lead to actual violence. This is also true for the Franciscan case: in the early fourteenth century, the convents of Narbonne and Béziers were held by Franciscans against other Franciscans by force of arms, ${ }^{9}$ and in 1318 four Spiritual Franciscans were burnt at the stake for heresy. ${ }^{10}$ However, the texts are not just polemical because they led to acts of violence in the real world; despite the rhetorical construction of a dialogue, they also display no willingness to accept that an opposing position might be tenable. ${ }^{11}$ While the treatises responded to points made by their opponents, a process characterised by Chiappini in his edition of the treatise Religiosi viri as a response et quoad rem et quoad verba, ${ }^{12}$ each side took the righteousness of their own claim for granted. At least in the initial stages of the conflict, however, there was a broad spectrum of views on what constituted the essence of Franciscan identity; the division between the opposing factions was neither clear-cut nor obvious, and both the viewpoints and chains of argument only became clear in the course of the debate. The rhetoric both suggested and created binary divisions which did not necessarily exist at the beginning of the conflict, and the polemical definition of positions helped to define and sharpen existing fault lines in the order by polarising the debate. ${ }^{13}$

All sides were engaged in the construction of what it meant to be a "true" Franciscan, often through a negative portrayal of their opponents in the order. This contribution focuses on some of the texts produced as part of the internal debate which use polemical means to respond to challenges posed to the authors' understanding of the Franciscan vocation by other members of the order. The treatises produced during the debates about Franciscan poverty had religious, political, ecclesiological and personal dimensions and implications, and the following analysis of some of their strategies is neither exhaustive nor intended to convey a comprehensive analysis of the issues raised by the Spiritual crisis and later debates about the fundamental basis of the Franciscan poverty ideal. It is, instead, intended to examine a number of the strategies used by the Franciscans engaged in these debates, especially when challenged by members of their own order rather than outsiders. This discussion revolved around the correct interpretation of the rule, often (but not exclusively) in light of St. Francis's Testament or perceived intention. ${ }^{14}$ The rule was central to Franciscan life, and carried an

7 See, for instance, Burr, Spiritual Franciscans, 113.

8 Southcombe et al., Introduction, especially 4-7. On the role of polemics in the developing discourse about heresy in a slightly earlier time period, see the collection of essays in Zerner, Inventer l'hérésie.

9 Lambert, Franciscan Poverty, 216-218. See also Nikolaus Glassberger, Chronica fratris Nicolai Glassberger, 124, for a general account of Franciscan splinter groups trying to secede from the order after 1310.

10 Lambert, Franciscan Poverty, 228.

11 Southcombe et al., Introduction, 6-7.

12 Chiappini, Communitatis responsio, 656.

13 See Piron, Mouvement clandestin, 4.

14 For the significance of this in early Franciscan history, see Maranesi, Intuizione e l’istituzione, and Pásztor, Intentio beati Francisci. 
enormous emotional resonance for the friars, to the extent that a long tradition in the order equated the rule with the gospels. It is not surprising, therefore, that Ubertino of Casale, one of the Spiritual spokesmen, accused his opponents of blasphemy against the rule and against St. Francis when summarising their argument that a restriction in the use of material goods did not fall under the Franciscan vow of poverty. ${ }^{15}$ Despite often disagreeing very vigorously, these texts were nevertheless engaged in the same enterprise: attempting to safeguard the Franciscan life and the intention of St. Francis as they understood it. The participants in the controversy therefore dealt with the fundamental question of what it meant to be a member of the Franciscan order, often by discussing how others misunderstood or misinterpreted the rule, or failed to live up to the vow in their daily lives. Their competing claims to authority made compromise difficult, and the stakes were high: explicitly or implicitly, everyone involved was engaged with the construction of Franciscan identity, and the texts therefore reveal changing definitions of what made a "good» and therefore »true« Franciscan.

\section{Ubertino of Casale and his opponents}

In 1309, Pope Clement V (1305-1314) set up a commission to enquire into the question of Franciscan poverty, after a series of clashes between supporters of Petrus Johannis Olivi and the opponents of Olivi's ideas. ${ }^{16}$ Representatives of the Spirituals as well as spokesmen for the Community were invited to the papal residence outside Avignon, a meeting which resulted in Clement's bull Dudum ad apostolatus in April 1310. ${ }^{17}$ Exempting the Spiritual spokesmen from the authority of their superiors, this decretal warned the order not to take any further action against them. Earlier acrimonious discussions had already led to violence, and Clement's exemption, while curbing physical violence, led to an "outburst of polemical literature" on the question of the usus pauper where, at least initially, the violence was intellectual. ${ }^{18}$ The bull was followed quickly by a new round of recriminations and pamphlets, and by the time of the Council of Vienne (1311-1312), the problem of the Franciscan order was still of such an explosive nature that it became one of the major issues of discussion at the council. ${ }^{19}$ There was a sense of danger to the order and its mission, to which the outcome of the papal inquiry and the debates at the council of Vienne were crucial. The texts engaging in this particular debate therefore show a heightened sense of urgency, as well as heavy emotional investment in the order's direction and the outcome of the discussion.

15 Ubertino of Casale, Super tribus sceleribus, in: Heysse, Ubertini de Casali opusculum, 159: Quod postea concludis, quod "usus pauper vel artus non cadit sub voto", cum oppositum eius in Regula concedatur, in Regulam et sanctum partum Franciscum probaris blasfemus: nam oppositum usus pauperis est usus opulentus vel dives, et arti superfluus et relaxatus; set hos usus Regula et Xhristi Evangelium plenarie interdicunt. On the significance of the rule, see also Lambert, Franciscan Poverty, 150-151, Schlageter, Armutsauffassung, 98, and Kinsella, Poverty of Christ, 492-493.

16 For a summary of the early development of what is generally referred to as the "Spiritual crisis«, see Burr, Spiritual Franciscans, 43-110. On the papal investigation of the Franciscan order, see particularly Lambert, Franciscan Poverty, 197-208, and Cusato, Whence »the Community«, 56-64. See also, most recently, Saccenti, Decree Exivi de paradiso, 32-44.

17 Cusato, Whence »the Community«, 60-62. An edition of Dudum ad apostolatus can be found on pp. 85-89 of Cusato's article.

18 Burr, Franciscan Spirituals, 113.

19 For the discussion of the Franciscan question at the Council of Vienne, see Müller, Konzil von Vienne, 236-386 and Lambert, Franciscan Poverty, 211-214. 
The papal enquiry wanted responses from both sides in this conflict, asking for views on a range of issues, including the observance of the rule in the order and the persecution of the Spirituals in southern France. ${ }^{20}$ The opposing sides coalesced around Ubertino of Casale for the Spirituals and Raymond de Fronsac for the order's Community, ${ }^{21}$ and the first part of this article explores the construction of a "good " Franciscan friar through these opponents' polemical discourses. The textual history of the responses to the pope's questions and the subsequent replies and counter-replies is complex and often confused; $;{ }^{22}$ as part of the debates at and around the papal curia in the period 1309-1312, Ubertino wrote an initial response to the questions of the papal commission, followed by a number of texts that defended that initial answer against counter-responses by the Community. Additionally, many of the texts generated by the curial debates in the 1310 s were collected into what is generally known, after Franz Ehrle, as the "Aktensammlung" of Raymond de Fronsac, probably in the early years of the pontificate of John XXII. ${ }^{23}$ The selection and arrangement of the documents for inclusion in Raymond's collection already constituted a vital part of the polemical process, and the collection was in itself an intervention in the ongoing discussion about the Franciscan ideal. ${ }^{24}$ The introduction suggested that, while the Spirituals had been vanquished for the time being, remnants remained, and Raymond had therefore collected relevant documents to be available as weapons should the need arise again. ${ }^{25}$ Very specifically intended as a weapon against the Spirituals, it constituted both a chronicle of recent events and an intervention in an ongoing debate. The military imagery is striking, as is the very Franciscan link made between the order's rule and true faith. Not only the content of the documents in the collection, but also the collection as a whole, are part of the polemical project of the Franciscan Community, quite literally and self-consciously. ${ }^{26}$

In the course of his own responses, Ubertino painted a vivid picture of a friar who did not agree with his own position that the Franciscan vow of poverty included mandatory restrictions in the use of material goods. Such a friar would have many habits and cloaks of scarlet and silk, lined with fur, many horses and golden and silver vessels, beds and other items. He would use these things like a prince, thinking all the while that he was living a true Franciscan life because everything he used belonged to the pope. According to Ubertino, this

20 Burr, Spiritual Franciscans, 113; other issues were Olivi's orthodoxy and the links between the Spirituals and the heresy of the Free Spirit.

21 For the terminology used by and for the factions in the order, and the significance of naming more generally, see Tognetti, Fraticelli, especially 97-101, and Ruiz, Communauté de l'ordre, 119-129.

22 On a brief survey of some of the issues, see Cusato, Whence »the Community«, 63-64. For the sake of convenience, I will cite Ubertino's texts in the edition by Franz Ehrle where possible, as well as drawing on his editions of the Community's response to Ubertino in Ehrle, Zur Vorgeschichte.

23 More research into the purpose of the collection and its use and reception is very desirable. For a discussion of the aims of the collection, see Ehrle, Zur Vorgeschichte, 2-5.

24 On the act of compilation as an assertion of orthodoxy, see also Grieco, Pastoral Care, Inquisition and Mendicancy, 154 .

25 Raymond de Fronsac, Sol ortus, in: Ehrle, Zur Vorgeschichte, 7-8: Et ideo ut Christi milites ac huius sancte religionis legitimi filii contra filios alienos in sua militia inveteratos arma habeant, quibus defendere valeant invincibilem atque incorruptibilem fidei et regulae veritatem.

26 In a similar way, the so-called chronicle of Nicolaus Minorita is part of the ongoing debate between the order's dissident leadership and Pope John XXII: see Nold, Pope John XXII and his Franciscan Cardinal, 1-24 and, most recently, Mierau, Sog. »chronica n. minorita«, 429-444. 
was obvious nonsense to anyone who was not insane. ${ }^{27}$ Assertion rather than argument is one of the hallmarks of polemical discourse, and Ubertino clearly saw himself as representing a self-evidently just cause, creating for himself and his supporters an identity which was defined against the lax friars of the Community. ${ }^{28}$ Ubertino's response also elided the many differences of opinion among the groups of people we normally classify as »Spiritual «, partly because they could all agree on this caricature of a worldly friar and their disdain for the lax standards of the rest of the order.

In many ways, Ubertino constructed a fairly typical portrait of a friar who did not subscribe to the idea of the usus pauper when he exaggerated the negative qualities that both gave rise to a rejection of the legal need for restraint in the use of material goods and that then necessarily led to disdain for the observance of poverty in the friar's daily life. Not only did this hypothetical friar disagree with Ubertino and the Spirituals on the definition of the Franciscan vow of poverty, but this disagreement also meant the friar would therefore amass personal luxuries, eat to excess, and disdain poverty. ${ }^{29}$ It is a common trope in Spiritual texts that rejection of the legal requirement of a restriction in the use of material goods would necessarily lead to the relaxation of standards in the order. Ubertino's lax friar was therefore not a true Franciscan; rather, he was someone who saw the vow of poverty in purely legalistic terms, and therefore did not think that his membership in the order should lead to material consequences in his daily life. Ubertino's implied image of an ideal friar is the exact opposite: someone who might not care particularly about the legal details of the Franciscan property arrangements, but who was very concerned about material consequences in daily life and the concrete manifestation of lived poverty.

It is not a coincidence that dress became one of the focal points of the debate, both as an identifier of allegiance and an outward sign of adherence to the "true « Franciscan vocation. Clothing made restraint in use (or lack thereof) very visible and obvious. ${ }^{30}$ By the time of the papal enquiry, a short and patched tunic had become the trademark and badge of the Spirituals, turning the Franciscan habit into a challenge to discipline and conformity in the order. The focus on dress was true for all sides: Spiritual rhetoric emphasised the rule's insistence on svile clothing', and claimed that this requirement was ignored by the majority of friars. ${ }^{31}$

27 Ubertino of Casale, Sanctitas vestra, in: Ehrle, Zur Vorgeschichte, 64-65: Nam si ex voto paupertatis regule non excluditur a nobis nisi dominium, non usus opulentus rerum, tunc quilibet frater potest habere multas tunicas et capas de scarleto et serico et foderaturas de vario, multos palafredos et vasa aurea et argentea et lectos et apparatus preciosos et cibaria iugiter exquisita et multa ad modum principum, dummodo dominium et proprietas sit pape; et cum tali vita erit verus pauper ewangelicus et frater minor, regule paupertatem observans; quod quanti sit deliramenti, patet omnibus non insanis.

28 See Southcombe et al., Introduction, 6 for the characteristics of polemics.

29 For similar instances, see Ubertino of Casale, Rotulus, in: Ehrle, Zur Vorgeschichte, 98 and 100, as well as his Declaratio, in: Ehrle, Zur Vorgeschichte, 187 (on the excessive consumption of meat).

30 For the significance of clothing in the debates, see Burr, Franciscan Spirituals, 119-120. See also Ubertino's texts: Rotulus, in: Ehrle, Zur Vorgeschichte, 98 and 100-102; Sanctitas vestra, in: Ehrle, Zur Vorgeschichte, 65-66; Declaratio, in: Ehrle, Zur Vorgeschichte, 176-178; and the Community response in Religiosi viri, in: Chiappini, Communitatis responsio, 668-669 and 672-674.

31 See Ubertino of Casale, Rotulus, in: Ehrle, Zur Vorgeschichte, 98: nam pluries in ipso introytu sic induuntur pretiosis et multiplicibus vestibus et informantur statim ad regule laxationem et conceduntur eis multe tunice pretiose et mutatoria tunicarum et calçones et alventa. See also Ubertino of Casale, Declaratio, in: Ehrle, Zur Vorgeschichte, 176, and his Sanctitas vestra, in: Ehrle, Zur Vorgeschichte, 65-66. 
On the other hand, the Community called for uniformity in observance and castigated the Spirituals for setting themselves apart through their short and patched habits. This is not only true for the polemical discourse at the curia, but can also be found in the legal documents produced during the conflict, such as the process against the Spirituals of Aquitaine in 1315 which contrasts the habits worn by "true Friars Minor" with those wilfully chosen by the Spirituals - the latter being a sign of disobedience that set their wearers apart from the order. ${ }^{32}$ This is linked to the perennial issue of the relationship between inner values and external practice in religious and especially monastic life, where regulations attempted to legislate observance in order to encourage inner disposition..$^{33}$ Raymond de Fronsac shows this clearly when he argued that the objection against the Spirituals' habits was not to their clothing per se, but rather to the fact that this dress was an outward sign of a lack of obedience and of a focus on external practice rather than internal values. He argued that in the case of the Spirituals, austerity in dress masked gluttony and boasting, and he accused his opponents of chasing after visions, spending too much time in the company of women, and defending erroneous and dangerous opinions, ${ }^{34}$ drawing on a range of anti-heretical tropes and stereotypes.

Among these are the many references to hypocrisy found in the discussion; the wellestablished link between hypocrisy, the pretence of sanctity and heresy also fits the debate into an eschatological framework which, although more pronounced in Spiritual writings than Community responses, was present in both..$^{35}$ Raymond de Fronsac's Sol ortus in particular placed his opponents explicitly into a heretical tradition going back to the Arians and Manicheans. ${ }^{36}$ There is also a remarkable continuity in the arguments used by the Community against Olivi and later against Ubertino at Vienne which placed the debate into a wider context and drew on established discourses inside and outside the order. ${ }^{37}$ Spirituals constructed a lax, worldly friar interested only in material goods and his own well-being, while

32 Oliger, Fr. Bertrandi de la Turre, 342: Et insuper reiecto habitu dicte religionis, quem veri fratres Minores sancte vite et conversationis honeste defferre consueverunt [...] et temeritate propria, absque licencia et iuditio suorum superiorum, quondam habitum diformem et disparum ab habitu fratrem communitatis sepedicti ordinis assumpserunt. On obedience as a key Franciscan virtue, see Binoy, Povertà e l'obbedienza, and Conrad, Gehorsam und Widerstand.

33 Brunner, Johannes XXII. als Reformer, 137-145.

34 In the response of the order's community, Raymond de Fronsac, Sol ortus, in: Ehrle, Zur Vorgeschichte, 102: Ad illud, quod dicit, quod vocantur superstitiosi, qui portant viles vestes; respondetur pro parte ordinis, quod non ex hoc vocantur superstitiosi, sed si ex hiis VI aliquid secum habere cum veste peregrina per opera agnoscantur, scilicet si sint superbi et contumaces circa obedientiam licitam et honestam; si exterius ostendant nimiam austeritatem in habitu et opera inveniantur laxi, scilicet gulosi, verbosi, iactativi, indevoti et similia prosequentes; si sint sompniorum vel fictarum visionum sectatores; si nimis frequentant colloquia mulierum potissime Beghinarum sub specie sanctitatis; si ceterorum meliorum se condempnatores; si perversorum dogmatum et errorum vel novarum et periculosarum opinionum defensores. Hec VI sunt, que in eis sub ostentationis habitu odivit anima mea.

35 See, for instance, Raymond de Fronsac's Sol ortus, which placed his opponents into a long line of heretics, including Arians, Manicheans, and the followers of Fra Dolcino (Ehrle, Zur Vorgeschichte, 10-11). Ubertino of Casale suggested that anyone who did not agree with the spiritual position that the usus pauper was part of the Franciscan vow of poverty derided Christ (Rotulus, in: Ehrle, Zur Vorgeschichte, 85). But see also Cusato on a more positive view of history and the future in the Franciscan Community: Cusato, Whence »the Community«, 73-76.

36 Raymond de Fronsac, Sol ortus, in: Ehrle, Zur Vorgeschichte, 10: qui sub specie sanctitatis et artioris vite ceteros contempnerant. For a more general discussion of the Spiritual Franciscans in the context of the history of heresy, see Lambert, Medieval Heresy, 208-235.

37 Burr, Spiritual Franciscans, 137. 
Raymond de Fronsac's counter-image shows a contumacious and hypocritical friar, obsessed with external signifiers over internal worth, consorting with women and undesirable people - again, drawing on well-established anti-heretical tropes..$^{38}$ Drawing a picture of a bad friar implied an image of a good one which, in the case of the Community, was characterised by obedience to the order's leadership and a focus on inner virtue rather than external practice. ${ }^{39}$ Despite this, both sides used external observance as a sign of internal adherence to "true Franciscan-ness", but had very different visions of what adhering to the rule entailed.

This argumentation did not leave any room for nuance and relied heavily on reductio ad absurdum, as well as personal attacks, such as Raymond de Fronsac's comment that if Ubertino stopped living at the papal court and returned to his fellow friars, he would realise that the brothers' food was austere rather than lavish..$^{40}$ The interesting point here is not the question of how lavish the dinners were in Franciscan convents - Raymond's response disqualified Ubertino from intervening in the debate because of his hypocrisy, and attempted to discredit the Spiritual spokesman before the pope. While there was a broad spectrum of views within the order on the question of the vow and its implications for the daily life of the friars, as well as a wide range of observance and practice of the Franciscan life within the order, responses such as this both personalised and polarised the issue. Although the back-and-forth of the responses can give the impression of a genuine argument, there was no real willingness to engage with the substance of the opposing side's point of view; rather, the debate consisted of claims and counter-claims. This was partly due to the fact that, while the treatises addressed each other, they were primarily aimed at the pope - the treatises and counter-treatises were meant to influence the papal decision-making process at the Council of Vienne and beyond, rather than being an attempt to convince opponents of the truth.

These brief examples highlight some of the ways in which the exchange of polemical treatises could produce competing visions of the Franciscan life. These visions are often, but not exclusively, focused on the practical details of the observance of the rule; the ideal friars constructed in the texts shared a regard for the rule of St. Francis, but they did not agree on its implementation. The polemicists also denied that anyone from the opposing side might share their regard. While the details of the argumentation shifted, the positions became more polarised as the debate went on, and neither side ever relinquished their claim to the truth.

38 Response of the Community, in: Ehrle, Zur Vorgeschichte, 102; see also Burr, Spiritual Franciscans, 120.

39 There can also be a more explicit discussion of what makes a good friar in the Community's responses: see, for instance, the treatise Religiosi viri, in: Chiappini, Communitatis responsio, 668-669: Falsum est etiam quod dicit, quod novitii non docentur vivere austere; nam novitiis semper datur magister, qui doceat eos pure confiteri, frequenter orare et spiritualia exercitia; immo et continue occupantur, nunc in addiscendo officium, nunc in orando, nunc in officiis infra domum; et si invenirentur novitiis in hiis deficere, non reciperentur prefessionem. This is not an image that seems very specifically Franciscan, however. The idea that poverty was a matter of will rather than (or at least in addition to) material circumstances had a long tradition in mendicant and anti-mendicant discourse: see Horst, Evangelische Armut und päpstliches Lehramt, 40, and Jones, Concept of Poverty, 427 and 432.

40 See the response of the Community, in: Ehrle, Zur Vorgeschichte, 103. See also Burr, Franciscan Spirituals, 120. It is important to note here, however, that these observations only hold true for the polemical discussion of Franciscan observance; while there is an equal unwillingness to engage in an open-ended debate, the discussion of the legal implications of the usus pauper is often detailed, complex and nuanced. 
The exchanges between Michael of Cesena and Gerald Odonis

A similar trajectory can be seen in the later exchanges between the deposed Franciscan Minister General Michael of Cesena and his successor Gerald Odonis, although both the conflict and the arguments played out differently. While the Spiritual crisis had, to a large extent, been about the interpretation of the Franciscan poverty ideal, the following decade saw the underlying doctrine called into question when Pope John XXII triggered a curial debate on the theological and legal basis of the Franciscan ideal of absolute poverty in 1322 . After about a year and a half of debate at the curia, the pope condemned the doctrine of the absolute poverty of Christ and the apostles in November 1323 in the bull Cum inter nonnullos. ${ }^{41}$ During this debate, both the opponents and the supporters of John XXII used a wide array of scriptural, theological, legal and ecclesiological arguments in order to support their views on the poverty of Christ and the status of the Franciscan order within the church. The pope's decision to declare the concept of the absolute poverty of Christ heretical in 1323 undermined the Franciscan way of life as well as the order's claim to occupy a unique position in the church, and it caused a dangerous rift between the Franciscan leadership and the papacy. Together with a number of prominent friars, including Bonagratia of Bergamo, William of Ockham and Francesco d'Ascoli, the Franciscan Minister General Michael of Cesena broke with John XXII and sought refuge in Munich with Emperor Louis the Bavarian. It seems clear that considerable uncertainty about the order's direction remained in the wake of the flight, even after the deposition of Michael and the election of Gerald Odonis as the new minister general in $1329 .{ }^{42}$ The pope's final intervention in the controversy on Franciscan poverty occurred in 1329 as well, with the publication of the bull Quia vir reprobus, but the debate continued between the dissident Franciscans in Munich and the new leadership of the order which remained loyal to the pope; they all became embroiled in a prolific and acrimonious exchange of treatises, pamphlets, accusations and counter-accusations that lasted for decades.

While this new iteration of the debate about Franciscan poverty covered old ground, the discussion also moved to new topics, especially the question of papal authority and the ecclesiological implications of the papal decision. ${ }^{43}$ During the Spiritual crisis, polemical exchanges had helped to construct different models of what it meant to be a Franciscan, but to a certain extent, the Michaelist debates after 1328 had a narrower focus on authority - both that of the pope and of the order's leadership although this had already been a subtext of the earlier conflict. In terms of polemical strategies, the Michaelist debates did not construct the image of a good Franciscan by painting an image of a bad friar in quite the same way as had happened during the Spiritual crisis. In the earlier debates, the Community had placed a lot of emphasis on obedience, both as a spiritual value and as a marker of membership in the order. ${ }^{44}$ This strategy was continued by Gerald Odonis against the dissidents in Munich.

41 General studies of the theoretical poverty controversy include Horst, Evangelische Armut und päpstliches Lehramt, especially 25-65 and 77-107, and Tabarroni, Paupertas Christi et apostolorum, as well as Lambert, Franciscan Crisis; Turley, John XXII and the Franciscans; and Oakley, John XXII and Franciscan Innocence.

42 On the break with the papacy and the dissidents in Munich, see Miethke, Ockhams Weg zur Sozialphilosophie, 414427. For a brief summary of Gerald's life and works, see the introduction to a special volume of Vivarium focusing on the theologian: Duba and Schabel, Introduction.

43 See, for instance, Tierney, Origins of Papal Infallibility, 171-237.

44 A point taken up by Pope John XXII in his condemnation of those who pretended to be Franciscan without obeying the order's leadership: see the bull Sancta Romana (1317), in Extrauagantes, ed. Tarrant, 200-201. 
The crucial difference to the earlier discussion was that members of the Community, such as Michael of Cesena and Bonagratia of Bergamo, now moved their focus from obedience to the order's leadership as a marker of Franciscan allegiance to the observance of, and obedience to, the rule. This echoed the earlier distinction made by supporters of Olivi who had placed observance of the rule over obedience to the order's leadership. Familiar arguments were re-used in different contexts, and the lines of argumentation were shifting, despite the continuing focus on the central Franciscan values of poverty and obedience.

Obedience to the order's leadership had been a central tenet of the Community during the Spiritual crisis, but this became problematic now that the leadership was contested. Michael of Cesena still regarded himself as the rightful minister general to whom allegiance was owed, but after his deposition, the discussion was caught up in the broader contemporary debate about papal power. In his response to Michael, Gerald Odonis claimed that his predecessor's act of withholding obedience from a rightful pope went against one of the most fundamental parts of the rule, and compared the former minister general to an ox bucking against the yoke. ${ }^{45}$ Gerald Odonis linked obedience to the pope with true obedience to, and proper observance of, the rule, suggesting that a rejection of papal authority amounted to a rejection of the rule and intention of St. Francis. However, until the quote from the Franciscan rule made it clear that this was about obedience to the pope, the same sentences could have been written by Michael of Cesena. Other than the question of whether John XXII was the rightful pope, there was often very little difference in the positions expressed by Michael and Gerald, and the Michaelist debates did not produce starkly competing visions of what it meant to be a Franciscan in the way the Spiritual crisis had done.

This does not mean, however, that the later discussion did not potentially have implications for the friars' identity and mission more generally: according to Michael of Cesena, "Those brothers who hold to the truth of the gospels and their profession and Exiit are the true Friars Minor and sons of St. Francis [...] and everything that pertains to the order, such as hearing confession and preaching, which have been conferred through the privileges of the church, pertains to them « ${ }^{46}$ Michael of Cesena's image of a true Franciscan here is characterised by adherence to the vow and to those papal declarations on the rule which preceded John XXII, but also by his mission: a true Franciscan did the work of a preaching friar and had access to the order's privileges which allowed him to carry out his mission. This, too, was linked to a construction of Franciscan identity which emphasised very different traits from those in earlier debates: one which focused on the work of the friars and their role in Christian society.

45 Responsio Geraldi, in: Nicolaus Minorita, Chronica, ed. Gál and Flood, 971: Sicut ergo nec fidei ita nec religionis nec regulae zelum habuisse probaris, quomodo ergo zelasti pro regula enormiter veniens contra primaria regulae fundamenta? Tu namque iugum oboedientiae sicut bos indomitus impudentissime reiecisti, cum tamen sanctissimus institutor nostri Ordinis, beatus Franciscus, dicat in principio regulae: "Frater Franciscus promittit oboedientiam et reverentiam domino papae Honorio ac successoribus eius canonice intrantibus et Ecclesiae Romanae."

46 Littera Michaelis, in: Nicolaus Minorita, Chronica, ed. Gál and Flood, 916: Liquet igitur quod illi soli fratres qui dictam veritatem evangelii et professionem dictae regulae quam voverunt et determinationem Ecclesiae catholicae in decretali Exiit traditam firmiter et fideliter tenent confidenter et servant et usque in finem servare volunt, sunt veri Fratres Minores et filii beati Francisci et in statu et via salutis, et coronam vitae suscipient, Domino concedente, sicut de ipsis dictus sanctus Franciscus, ut praedictum est, prophetavit, et quod ad ipsos spectat et pertinet officium audiendi confessiones et praedicandi et cetera alia faciendi, quae per privilegia sanctae catholicae Ecclesiae fratribus beati Francisci regulae sunt concessae. 
Michael's positive focus on privileges obliquely echoed some of the concerns raised during the Spiritual controversy about the relationship between papal privileges and the Franciscan vocation; it was also a construction of the Franciscan vocation that came straight out of the very specific context of a polemical debate between two rival ministers general.

Observance of the rule remained central to the construction of Franciscan identity, however; this can also be seen in the number of personal attacks in this exchange. In his response to Michael of Cesena's letter, Gerald Odonis accused his predecessor of keeping money in his room at Munich. In doing so, he accused Michael of a straightforward violation of the Franciscan rule and his vow of poverty, adding gleefully that Francesco d'Ascoli had been robbed of similarly illicit possessions during his flight from Italy to Munich. God's judgement had therefore forced Francesco to accept the poverty he had not wanted to observe of his own will. ${ }^{47}$ Nobody could or did argue that keeping money was acceptable, and this accusation was therefore designed to undermine Michael of Cesena and the leaders of the Franciscan dissidents by portraying them as hypocrites who did not follow even the most basic precepts of the rule. The personalisation of larger issues and accusations of hypocrisy, of not living up to the obligations of the vow, are similar to the way in which the debate was conducted during the Spiritual controversy, but to some extent, the focus in this later exchange was on accusation and counter-accusation in a much more straightforward manner. The lines between the factions started to shift during and after John XXII's interventions, when a number of prominent spokesmen for the Community found themselves on the receiving end of very similar polemical discourses to those they had themselves produced earlier.

Michael of Cesena's response to the accusation of owning money was, predictably, a flat denial and the counter-accusation that it was Gerald Odonis who wanted to remove the prohibition on handling money from the rule. ${ }^{48}$ According to Michael, the general chapter at Perpignan in 1331 had considered abolishing the order's prohibition on handling money; the proposed changes were to make it possible for the order to receive money through intermediaries relying quite heavily on the discretion of the order's leadership. ${ }^{49}$ What exactly happened in the summer of 1331 remains unclear, although to some extent the more important question is the way in which the episode was discussed and used by Michaelist polemicists..$^{50}$ Accusing Gerald of a direct attack on the Franciscan rule made the debate into a conflict about Francis' legacy that went beyond the question of the correct interpretation of the rule. No true Franciscan would change the rule and thus betray the order's founder. This tied the

47 Responsio Geraldi, in: Nicolaus Minorita, Chronica, ed. Gál and Flood, 972: contra votum paupertatis, proprietarius fuisti et alios proprietarios plurimosque fecisti [...] quod tu pecuniam ad Monachum in camera tua tenes [...] Unde Franciscus de Aesculo, tuae iniquitatis complex, pergens de Cumis versus Monachum, inventus est super se immediate portare octoginta florenos. Sed quia nequaquam de bono iure fuerunt, praedones eos, divino iudicio, rapuerunt, ut expropriationem quam non servabat voluntaries, servaret invitus.

48 Replicatio Michaelis, in: Nicolaus Minorita, Chronica, ed. Gál and Flood, 976: tu in tua convocatio, facta Perpiniani, totis viribus et nefariis ausibus, per falsos colores et nullos, conatus es et molitus oppositum et contrarium ac omnino repugnantem sensum et intellectum dare regulae, allegando et inducendo mendaciter etdiabolice quod praedictum punctum regulae de nullo modo recipiendo pecuniam per se nec per interpositam personam non intelligatur de fratribus infirmis seu de necessitatibus infirmorum, nec etiam de necessitatibus pro fratribus induentibus.

49 On the chapter of Perpignan, see particularly Desbonnets, Constitutions générales de Perpignan, 69-99. See also Nold, John XXII's Annotations, 311-323 and Heysse, Duo documenta de polemica, 154-155 and 180.

50 For another version of the story, see the Chronica XXIV generalium, 504-506. The Replicatio Michaelis, in: Nicolaus Minorita, Chronica, ed. Gál and Flood, refers to it a second time on p. 1004. 
controversy back to the earlier debate and to the use made of Francis' intention in constructing Franciscan identity more broadly, but it also raised the stakes: the image painted of Gerald Odonis was not only that of someone unfit to lead the order, but as an enemy of the Franciscan vocation.

Despite this, and although the rhetoric is often very similar to the debates surrounding the Spiritual crisis and the Observant movement, Michael of Cesena and Gerald Odonis did not construct rival images of the ideal Franciscan; underneath the personal attacks and insults, they agreed on many key ideas. Moreover, the overlapping and competing images of the good friar produced in these exchanges were not wholly incompatible or mutually exclusive. This might be one of the reasons why the definition of a "good« Franciscan often went hand-in-hand with the claim that those outside that definition were, not "bad " Franciscans, but rather not really Franciscans at all. There is an explicit denial that those who refused proper obedience could be part of the order: Michael of Cesena accused the followers of Gerald Odonis of leading not a Franciscan life, but one based on the ideas of John XXII. They were therefore pseudo-brothers, not real ones, and members of a schismatic group..$^{51}$ Everyone obeying Gerald fell outside the strue obedience of the rule and therefore the religion instituted by St. Francis. ${ }^{52}$ This trend cuts across the distinction between those advocating opposing Franciscan ideals and those focusing on obedience. The categorisation of members of the order by and through obedience not only made transgressors into bad Franciscans, but placed them outside the order altogether; every friar was potentially someone else's pseudo-friar.

It is in many ways less than clear what Michaelist rhetoric was trying to achieve. Many of the later Michaelist texts are long, repetitive and tedious, and it is unclear who was expected to read them, outside the very narrow circle of people in which they were produced. ${ }^{53}$ Making it clear that an opponent's views were untenable was as much an affirmation of the Michaelists' own position as an attempt to change the mind of their opponents. Invective was part of this process, although the effect of these rhetorical attacks and insults is not always very clear, beyond validating the positions held to those people who were already convinced. The Michaelist texts might also have provided some comfort to an isolated group of people stuck in the middle of nowhere with no realistic prospect of change. Polemics could work in this context as a form of identity discourse where the implied audience was different from the people to whom the texts are ostensibly addressed. Despite this, the authors of these texts engaged very directly with their opponents. These opponents were often named, and

51 Littera Michaelis, in: Nicolaus Minorita, Chronica, ed. Gál and Flood, 915: Et ad demonstrandum manifeste per confessionem pseudo fratrum, sequendum dictum Iacobum haereticum, quod dicta professio et status dicti Ordinis sunt haereticales.

52 Littera Michaelis, in: Nicolaus Minorita, Chronica, ed. Gál and Flood, 914: et quod omnes illi qui sibi aut aliquibus, institutis <in> officiis aliquibus per ipsum oboediunt sunt extra oboedientiam regulae et religionis institutae per sanctum Franciscum.

53 In the context of the chronicle of Nicolaus Minorita, see on this point particularly Mierau, Sog. "chronica n. minorita", 429-430. Also important in this context is the manuscript tradition which places interest in the collection in Avignon rather than Michaelist circles (see Mierau, Sog. »chronica n. minorita", 429-439). A similarly detailed study of the materials compiled by Raymond de Fronsac and its transmission remains a desideratum. 
the discussion was personal, but they also stood in for larger sections of the order and wider concerns. The polemics were embedded in a layer of more complex arguments about papal power, ecclesiology and rights, and in many ways the debate became self-perpetuating, assuming a life of its own and becoming increasingly ritualised. ${ }^{54}$

\section{Conclusion}

The Franciscan debates of the early fourteenth century saw an increasingly complex exchange of ideas on what constituted the essence of the Franciscan vocation. The proponents of all sides in these debates saw themselves as the true successors of St. Francis, constituting the true order, both in spirit and in practice. The Spirituals largely based their definition of the Franciscan vocation on the proper observation of poverty, including the usus pauper, and excluded anyone from this definition who supported the current leadership..$^{55}$ The Community, in the debates about practice, and all sides in the Michaelist debates, based their definition of who belonged to the order not so much on the question of how to define or enact the Franciscan vocation, but rather on the willingness to accept the authority of church and order to make binding decisions in these matters. The shifting boundaries of inclusion and exclusion were partly bound up with the question of who had the authority to decide, and language and imagery often shifted towards violence. The discussion shows continuities with earlier polemical projects; it uses similar strategies, especially anti-heretical stereotypes and a focus on hypocrisy among opponents. Shifting boundaries can be seen in the unstable terminology employed to describe opponents, especially the various ways in which the Community referred to the Spiritual Franciscans and later the Michaelists.

It is therefore significant that both "Spirituals" and "Community" as labels for factions in the order were first used during the curial debates in the 1310s. Ubertino of Casale first referred to his own side as "Spirituals" when he discussed the wearing of shoes rather than sandals, which according to him was a practice observed by almost all friars, "apart from those which are called Spirituals «. ${ }^{56}$ Ubertino treated this as a commonly known term, but, crucially, did not say who exactly called those shoeless friars "Spirituals". In the proceedings against them in 1316, a group in Aquitaine was accused of insisting on being called "spiritual brothers «, although they denied this charge. ${ }^{57}$ In a similar way, the term communitas arose in the course of the same debate and only in contradistinction to the Spirituals..$^{58}$ The term is self-referential and was only used once the papacy had removed the Spirituals from the order's jurisdiction; it therefore represents the attempt to establish once and for all that

54 See Flasch, Einführung in die Philosophie des Mittelalters, 120. For a discussion of some of these issues with respect to the theoretical poverty controversy, see Conrad, »Theoretischer Armutsstreit«, 171-190.

55 It is important not to over-simplify the range of positions held by Spirituals on different issues, however, including, but not limited to, poverty. Even Ubertino, in a slightly disingenuous passage, warned of binary oppositions, when he argued that not everyone in the order who did not support the Spirituals ought to be condemned - although they were, at best, misguided: Ubertino of Casale, Sanctitas vestra, in: Ehrle, Zur Vorgeschichte, 85.

56 On this point, see Şenocak, Poor and the Perfect, 13; Ubertino of Casale, Rotulus, in: Ehrle, Zur Vorgeschichte, 101: preter paucos, qui spirituales dicuntur. On the polemical construction of a Spiritual identity in a slightly different context, see also Burr, History as Prophecy, 119-138.

57 Oliger, Fr. Bertrandi de la Turre, 339: qui se faciunt fratres spirituales.

58 Cusato, Whence »the Community «, 64; see also Religiosi viri, in: Chiappini, Communitatis responsio, 659-662 and Communitatis abbreviatura, in: Heysse, Fr. Richardi de Conington tractatus, 66. 
the Community was the order. ${ }^{59}$ And, while initially used by only a few people, especially Raymond de Fronsac and Bonagratia of Bergamo, it increasingly became the way in which the Franciscan leadership distinguished the order from those whose continued disobedience placed them outside it. ${ }^{60}$ The process of categorisation was part of the formation of distinct Franciscan identities, and this process defined the Community of the order just as much as it defined its dissidents. Inasmuch as there ever was a consensus of what it meant to be a Franciscan, it only developed in the course of the debates, at the end of which certain interpretations of Franciscanism came to be defined as illegitimate.

Important for the more general questions of patterns of argumentation is the context in which these texts were produced. For the Spiritual crisis, the large majority of material was produced in response to the papal enquiry of 1309 and the debates in the run-up to and at the Council of Vienne. This means that while the arguments were addressed to the opponents in the debate, they were also and particularly aimed at the pope, who needed to be convinced to lend his support. Despite the fact that Raymond de Fronsac's collection contains responses and counter-responses, as well as point-by-point refutations of opponents' views, the debate was not open, either in the sense that there was any real possibility of changing an opponent's mind, or of any willingness to accept the "wrong" papal decision. The texts generated by the conflicts therefore served several purposes: they appealed to the pope, they drew and re-drew the boundaries between »true« and »false" Franciscans, and they reinforced a sense of identity that was only created in the process of the debate. The various genres and texts produced during these debates responded to specific situations, and they addressed specific audiences; their polemical content is an important part of these works, but it is not the only thing about them. It is important to recognise the specific contexts and starting-points of the debates, as ideas and concepts were only articulated during the course of the debate, even as the positions hardened and became more intransigent. The exchanges were therefore a process of differentiation between groups with comparable profiles, ${ }^{61}$ and contributed to a sense of institutional separation between the order and those defined outside it. ${ }^{62}$ The polemical context of the exchanges had a direct effect on this articulation, as it was only in the course of the debate that the competing visions of Franciscan identity developed. The boundaries between acceptable and inacceptable behaviour and opinions shifted during this series of arguments and conflicting claims over the correct interpretation of the Franciscan ideal, which often focused on the friars' relationship with material goods, but also on obedience and the role of legitimate authority. In the case of the conflict between Michael of Cesena and Gerald Odonis, polemics hardened to a near interchangeable exchange of stereotypical images of disobedience, demonstrating the re-use of earlier material in new alignments and to achieve new ends. While the construction of dissenting voices as fraudulent and hypocritical was a constant theme, the categories used to determine who and what counted as "truly« Franciscan changed and developed over time. The use of polemics allowed all participants in the debates to construct themselves as the true heirs of St. Francis, and in this process, the exclusionary nature of the polemical construction of Franciscan identity shaped both its boundaries and limits.

59 Cusato, Whence »the Community«, 65; this can also be found in Raymond de Fronsac's Sol ortus, in: Ehrle, Zur Vorgeschichte, 11: the indecent clothes worn by the Spirituals dampnabant ceteros de communitate ordinis.

60 Cusato, Whence »the Community«, 66.

61 See Piron, Mouvement clandestin, 3 on the relationship between Spirituals and early Observant movement.

62 A point made in Tognetti, Fraticelli, 83, but which is more widely applicable. 


\section{Acknowledgements:}

I would like to thank the participants in the sessions on "Religious Polemics Compared « at the International Medieval Congress in Leeds 2016 for their comments on a previous version of this paper, and Sita Steckel for organising the sessions. I would also like to thank Geoffrey Humble for some very perceptive questions during the rewriting of the paper. 


\section{References}

Primary sources

Chiappini, Anicetus, Communitatis responsio Religiosi viri ad Rotulum Fr. Ubertino de Casali, Archivum Franciscanum Historicum 7 (1914) 659-675; and Archivum Franciscanum Historicum 8 (1915) 56-80.

Chronica XXIV generalium, ed. by the Collegium S. Bonaventurae (Quaracchi, 1897).

Extrauagantes Iohannis XXII, ed. Jacqueline Tarrant (Città del Vaticano, 1983).

Glassberger, Nikolaus, Chronica fratris Nicolai Glassberger, ed. by the Collegium S. Bonaventurae (Quaracchi, 1887).

Heysse, Albanus, Duo documenta de polemica inter Gerardum Oddonis et Michaelem de Caesena (Perpiniani 1331 - Monachii 1332), Archivum Franciscanum Historicum 9 (1916) 134-183.

Heysse, Albanus, Ubertini de Casali opusculum Super tribus sceleribus, Archivum Franciscanum Historicum 10 (1917) 103-174.

Heysse, Albanus, Fr. Richardi de Conington tractatus de paupertate Fratrum Minorum et abbreviatura inde a communitate extracta, Archivum Franciscanum Historicum 23 (1930), 57-105.

Nicolaus Minorita, Chronica: Documentation on Pope John XXII, Michael of Cesena, and the Poverty of Christ with Summaries in English: A Sourcebook, ed. Gedeon Gál and David Flood (St. Bonaventure, NY, 1996).

Oliger, Livarius, Fr. Bertrandi de la Turre processus contra Spirituales Aquitaniae (1315) et card. Iacobi de Columna litterae defensoriae Spiritualium Provinciae (1316), Archivum Franciscanum Historicum 16 (1923) 323-355.

Secondary sources

Binoy, Thomas, La povertà e l'obbedienza nelle costituzioni dell'Ordine dei Minori (1239-1517) e dei Frati Minori Conventuali (1517-1932), Miscellanea Francescana 111 (2011) 77-122.

Brunner, Melanie, Johannes XXII. als Reformer? Päpstliche Verwaltungspolitik und Ordensreform von oben, in: Hans-Joachim Schmidt and Martin Rohde (eds.), Papst Johannes XXII.: Konzepte und Verfahren seines Pontifikats (Berlin, 2014) 119-148.

Burr, David, Olivi and Franciscan Poverty: The Origins of the "usus pauper« Controversy (Philadelphia, 1989).

Burr, David, The Spiritual Franciscans: From Protest to Persecution in the Century after Saint Francis (University Park, 2001).

Burr, David, History as Prophecy: Angelo Clareno's Chronicle as a Spiritual Franciscan Apocalypse, in: Michael F. Cusato (ed.), Defenders and Critics of the Franciscan Life: Essays in Honour of John V. Fleming (Leiden, 2009) 119-138.

Condren, Conal, Rhetoric, Historiography and Political Theory: Some Aspects of the Poverty Conflict Reconsidered, Journal of Religious History 13 (1984) 15-34.

Conrad, Susanne, Der »Theoretische Armutsstreit« als Medienereignis: Neue Beobachtungen in kommunikationstheoretischer Absicht, in: Reinhardt Butz (ed.), Studia monastica: Beiträge zum klösterlichen Leben im christlichen Abendland während des Mittelalters (Münster, 2004) 171-190.

Conrad, Susanne, Gehorsam und Widerstand im Franziskanerorden: Bertrand de la Tour und die "rebelles« im Jahr 1315, in: Sébastian Barret (ed.), Oboedientia: Zu Formen und Grenzen von Macht und Unterordnung im mittelalterlichen Franziskanerorden (Münster, 2005) 409-422. 
Cusato, Michael F., Whence »the Community«?, Franciscan Studies 60 (2002) 39-92.

Desbonnets, Théophile, Les Constitutions générales de Perpignan (1331), in: I Francescani nel Trecento, Atti del XIV convegno internazionale: Assisi, 16-17-18 ottobre 1986 (Perugia, 1988) 69-99.

Duba, William, Schabel, Chris, Introduction, Vivarium 47 (2009) 147-163.

Ehrle, Franz, Zur Vorgeschichte des Concils von Vienne (Schluß), Archiv für Litteratur- und Kirchengeschichte des Mittelalters 3 (1887) 1-195.

Flasch, Kurt, Einführung in die Philosophie des Mittelalters (Darmstadt, 1987).

Grieco, Holly, Pastoral Care, Inquisition and Mendicancy in the Medieval Franciscan Order, in: Donald S. Prudlo (ed.), The Origin, Development, and Refinement of Medieval Religious Mendicancies (Leiden, 2011) 117-155.

Horst, Ulrich, Evangelische Armut und päpstliches Lehramt: Minoritentheologen im Konflikt mit Papst Johannes XXII. (1316-34) (Stuttgart, 1996).

Jones, John D., The Concept of Poverty in St Thomas Aquinas's Contra impugnantes Dei cultum et religionem, Thomist 59 (1995) 409-439.

Kinsella, Sean, The Poverty of Christ in the Medieval Debates between the Papacy and the Franciscans, Laurentianum 36 (1995) 477-509.

Lambert, Malcolm D., The Franciscan Crisis under John XXII, Franciscan Studies 32 (1972) 123-143.

Lambert, Malcolm D., Franciscan Poverty: The Doctrine of the Absolute Poverty of Christ and the Apostles in the Franciscan Order 1210-1323 (revised edition), (St. Bonaventure, NY, 1998).

Lambert, Malcolm, Medieval Heresy: Popular Movements from the Gregorian Reform to the Reformation (third revised edition), (Oxford, 2002).

Maranesi, Pietro, L'Intuizione e l'istituzione. Il travaglio dell'identità di Francesco e dei suoi frati nei testi giuridici, Miscellanea Francescana 108 (2008), 169-203.

Mierau, Heike Johanna, Die sog. »chronica n. minorita«: Rezeptionswege und das sich wandelnde Bild von Johannes XXII., in: Hans-Joachim Schmidt and Martin Rohde (eds.), Papst Johannes XXII.: Konzepte und Verfahren seines Pontifikats (Berlin, 2014) 427-465.

Miethke, Jürgen, Ockhams Weg zur Sozialphilosophie (Berlin, 1969).

Miethke, Jürgen, Der »theoretische Armutstreit« im 14. Jahrhundert. Papst und Franziskanerorden im Konflikt um die Armut, in: Heinz-Dieter Heimann (ed.), Gelobte Armut. Armutskonzepte der franziskanischen Ordensfamilie vom Mittelalter bis zur Gegenwart (Paderborn, 2012) 243-283.

Müller, Ewald, Das Konzil von Vienne 1311-1312. Seine Quellen und seine Geschichte (Münster, 1934).

Nold, Patrick, Pope John XXII and his Franciscan Cardinal: Bertrand de la Tour and the Apostolic Poverty Controversy (Oxford, 2003).

Nold, Patrick, John XXII's Annotations on the Franciscan Rule: Content and Contexts, Franciscan Studies 65 (2007) 295-324.

Oakley, John, John XXII and Franciscan Innocence, Franciscan Studies 46 (1986) 217-226.

Pásztor, Edith, Intentio beati Francisci: il percorso difficile dell'ordine francescano (secoli XI$I I-X V$ ), ed. Felice Accrocca (Roma, 2008).

Piron, Sylvain, Le Mouvement clandestin des dissidents franciscains au milieu du XIV siècle, Oliviana 3 (2009) 1-30.

Ruiz, Damien, La Communauté de l'ordre et la papauté d'Avignon, Il Santo 42 (2002-2003) 117-136. 
Saccenti, Riccardo, The Decree Exivi de paradiso and its Implications for Mendicant Poverty, in: Constant J. Mews and Anna Welch (eds.), Poverty and Devotion in Mendicant Cultures 1200-1450 (London, 2016) 32-44.

Schlageter, Johannes, Wurde die Armutsauffassung des Franziskus von Assisi von der »offiziellen Kirche« schließlich abgelehnt? Francisci Armutsverständnis und der Streit über »dominium Christ« und "paupertas Christi« unter Papst Johannes XXII. (1316-1334), Franziskanische Studien 60 (1978) 97-119.

Schlageter, Johannes, Das Heil der Armen und das Verderben der Reichen: Petrus Johannis Olivi OFM. Die Frage nach der höchsten Armut (Werl, 1989).

Şenocak, Neslihan, The Poor and the Perfect: The Rise of Learning in the Franciscan Order 12091310 (Ithaca, 2012).

Southcombe, George, Suerbaum, Almut, Thompson, Bejamin, Introduction, in: Suerbaum, Almut, Southcombe, George, Thompson, Benjamin (eds.), Polemic: Language as Violence in Medieval and Early Modern Discourse (Farnham, 2015) 1-14.

Tabarroni, Andrea, Paupertas Christi et apostolorum. L'ideale francescano in discussione (13221324) (Roma, 1990).

Tognetti, Giampaolo, I Fraticelli, il principio di povertà e i secolari, Bullettino dell'Istituto storico italiano per il Medioevo 90 (1982-1983) 77-145.

Tierney, Brian, Origins of Papal Infallibility, 1150-1350: A Study on the Concepts of Infallibility, Sovereignty and Tradition in the Middle Ages (revised edition), (Leiden, 1988).

Turley, Thomas, John XXII and the Franciscans: A Reappraisal, in: James Ross Sweeney and Stanley Chodorow (eds.), Popes, Teachers, and Canon Law in the Middle Ages (Ithaca, 1989) 74-88.

Zerner, Monique (ed.), Inventer l'hérésie? Discours polémiques et pouvoirs avant l'Inquisition (Nice, 1998). 


\section{Obediencia, reformatio and veritas: Ecclesiological Debates during the Western Great Schism (1378-1417)}

\section{Bénédicte Sère*}

The following is a brief presentation of the polemical strategies of textual discourses during the Great Schism. Our aim is to think of the history of the Great Schism as the history of the symbolic violence shaping the debates. The paper suggests joining the recent movement of what Jean-Pascal Gay calls "a cultural history of the controversial fact " to better grasp the ecclesiological advances of this late medieval period.

Keywords: Great Schism; ecclesiology; polemics; theology; violence; universities; Paris; Jean Gerson

Quid est igitur quod innuis mihi quasi non liceat de potentia Petri disputare? Nonne de omnipotentia Dei quotidie perquirimus? ${ }^{1}$ With these words, delivered during a famous sermon in front of the Avignonese Pontiff Benedict XIII, Jean Gerson expounded an idea dear to him: the right of discussion concerning papal authority, a sort of jus disputandi, already sketched by John of Paris during the years 1302-1303. ${ }^{2}$ With this claim, Gerson demonstrated that it was possible to discuss Peter's power, de potentia Petri disputare, within the framework of rules set up by the scholastic art. Such a discussion was, literally speaking, to be an investigation (inquirere, perquirimus). Indeed, if theologians spent all day long discussing God's omnipotentia, why would they not also discuss Peter's power? ${ }^{3}$

Exploring this attempt to re-shape controversy within the late medieval Latin church, the following is a brief analysis of the polemical strategies of textual discourses during the Great Western Schism. ${ }^{4}$ The article aims to rethink the history of the Great Schism as a history of symbolic violence shaping specific cultures of debate. With this aim, the article joins the enterprise of what Jean-Pascal Gay calls "a cultural history of the controversial fact « to provide a better understanding of the ecclesiological advances of the late medieval period ${ }^{5}$.

* Correspondence details: Dr. Bénédicte Sère, Université Paris Nanterre, 200 avenue de la République, 92001 Nanterre Cedex. Email: benedicte.sere@sfr.fr.

1 Jean Gerson, Sermo habitus Tarascone coram Benedicto XIII, ed. Glorieux, V, § 212, 72.

2 See the quaestio of Jean Quidort, De potestate regia et papali, ed. Bleienstein, c. 22, 192-196: An licitum sit de huiusmodi pertinentibus ad papam disputare et judicare. Cf. also the later insistence: Tanto magis in talibus est veritatem inquirere, quanto periculosius esset in hoc non cognoscere veritatem. On this topic, see Briguglia, Inquirere veritatem, 13-14.

3 Jean Gerson, Sermo habitus Tarascone coram Benedicto XIII, ed. Glorieux, V, § 212, 72.

4 See Sère, Débats d'opinion.

5 Gay, Lettres de controverses, 10-11. 
At the outset, a brief review of the historical context of the Great Schism, in force from 1378 to 1418 , can serve a double purpose: it can offer a compressed background and present the complexity of different cultures of conflict resolution coming into play. In April 1378, the Archbishop of Bari, Bartolomeo Prignano, was elected pope and called himself Urban VI, but the election was contested by the French part of the Sacred College, the College of Cardinals, who decided in September 1378 to elect a different pope, Robert of Genève, who called himself Clement VII, thus beginning the Great Schism. As a consequence of the Schism, all Christendom split into two obediences, an `Urbanist and a `Clementist one. The geopolitic map of the period aligned itself with the map of these two obediences: while France, Castille and Scotland were Clementist, England and Aragon were Urbanist. The Schism has been divided into two phases by historians like Hélène Millet. During the first period (1378-1394), the contestants followed a spath of winning, in which each camp tried to impose the rights of its own pope. During the second phase, from 1394 onwards, each camp saw union of the church as the paramount goal. Yet the proposed methods of resolution varied. From the 1390 s, for example, the University of Paris proposed the via cessionis, that is to say the double abdication of the popes in order to reelect a new one. In 1398, a third assembly of the French clergy passed a vote entailing a formal subtraction of obedience in order to force the pope to resign. An alternative solution, the via concilii, saw a council as the preferred instrument of union, resulting in the councils of Pisa in 1409, of Rome in 1412, and finally the Council of Constance in 1414-1418. As is known, the Council of Constance elected a new sole pope, Martin V, ending the Great Schism on November 11th, 1417.

Let us, secondly, turn to a methodological consideration. Rather than writing a shistory of ideas،, it seems more meaningful for a history of controversy today to reconstitute the intertextuality of the period, to observe the way in which texts echo each other. Polemical texts, understood broadly here as texts setting out opposing positions, necessarily become more understandable when these contexts are made clear. As Marie-Dominique Chenu did in his work on Thomas Aquinas, or Philippe Büttgen in his work on Luther, we need to establish the "doctrinal conjuncture " of the Gersonian period, to use the broad panorama of a relatively brief historical experience which also allows us to articulate long-term trends. ${ }^{6}$

Methodological impulses can be taken from Michel Foucault (followed by Alain de Libera), who stated that texts make sense only in conceptual networks and, especially, in networks of particular historical corpora. ${ }^{7}$ Debates on specific issues are, after all, not isolated but take place within much wider discussions, and this polemicity of discursive practices is fully apparent in the field of ecclesiology, which cannot be separated from questions of power and symbolic violence. As medievalists, we can also take up impulses from the research field we might call the shistory of controversies,${ }^{8}$ which, deriving from the history of science, has mostly been suggested by historians of the modern period. ${ }^{9}$

See Chenu, Introduction à l'étude de saint Thomas d'Aquin; Büttgen, Luther et philosophie. See also Piron, Contexte, situation, conjoncture.

7 Foucault, Archéologie du savoir; de Libera, Analyses du vocabulaire.

8 For instance, see Fabiani, Dispute, polémiques et controverses.

9 Among many, see Lilti, Querelles et controverses; Gay, Morales en conflit; Gay, Lettres de controverse; de Franceschi, Crise théologico-politique; Bernat and Bost, Énoncer/dénoncer l'autre; Postel, Traité des invectives; Nagy et al., Controverses religieuses; Jouhaud, Pouvoirs de littérature, or Burnand and Paschoud, Espaces de la controverse; Broggio, Teologia et la politica. 
The period of the Great Schism, a brief but dense historical constellation, allows us to bring the heuristic tools suggested by these perspectives to bear: we can not only study polemical exchanges and their links to socio-historic realities, but also inquire about the cultural productivity of the debates themselves, the practices they engendered or pushed aside, and the way they produced redistributions or new balances of power. As such an approach can uncover, debates themselves can become objects of history, appropriating the issues of a conflict and bringing the basis of political and factual dynamics to light.

To put it differently, debates are not just interesting because of their content and arguments, but also as historical objects in themselves - and indeed even as historical actors or forces, which may very well effect specific transformations. We may thus engage in an approach which aims to establish a spolemology<, though this does not necessarily mean that polemical discourses or their contents should be central for their own sake. Rather, the issue at stake is the sculture of conflict', and the goal is to write a scultural history of controversies،.

To break this down to concrete methodical concerns, we can depart from the assumption that debates occur in a precise context of production with bases, sources and textual networks. Such backgrounds enable us to construct a framework of the debates within the temporal context of the events. As a next step, we can describe the practices of the debates in a phenomenological approach providing a thorough description. Further questions may concern the genres of the debate, its rhythm, the circulation of the debates, the strategies of engagement, the resulting networks, their solidarities, affiliations and allegiances as well as the issues of the debates. The function of such a narrative and phenomenological approach is to situate the roots of the specific genre of debate in its context, its conditions of possibilities as well as in its practices, in order to observe the production of intellectual or doctrinal content at work.

To provide an example illustrating this approach, the following pages will develop the central issue of the period set out by Gerson in the opening quotation above - that is, the concept of obedientia, or rather, its inversion, the jus resistendi. This example can help us to follow the interpenetration of doctrinal issues and debates, documenting how debates produce doctrines. The discussion of this issue began with preliminary works in the years 1395-1396. A seminal text in which everything was concentrated was then produced with the well-known Simon of Cramaud's De substraccione obedience, also called Nunc reges intelligite! The issues raised at this point then continued to be debated until 1418. Particular texts throughout this development allow us to follow the reception of the idea of a jus resistendi, in the form of rejections, reluctances or adhesions. A particular thread which can be highlighted as a coherent development concerns the frequent use of the exegesis of Galatians 2. 11, an episode in which Paul resists Peter. The later episodes of the debate played on controversial exegesis, with texts responding to each other and establishing deeper connections. The following discussion will remain close to the exegesis of Galatians 2. 11 to keep the argumentation focused. 
Paul in front of Peter: the exegesis of a model of resistance (Galatians 2. 11)

The polemical literature of the Great Schism abundantly drew its models of behavior and its rhetorical justifications from biblical figures. Biblical history showed that it was not unusual for inferiors to correct or reprimand (reprehendere) their immediate superiors. The examples quoted were all the more convincing as the inferiors addressed the political elders even if these were Moses, David, Achaz, Sedecias, Herod or Peter. The most developed biblical example is that of Paul who resisted Peter, qui in facie restitit. ${ }^{10}$

One might say that a veritable chain of reflection spread around Galatians 2. 11 during the period under consideration, to the point of constituting an exegetic thread in which Paul was set up as a model of resistance to the Petrinian authority. He offered himself as the patron of Subtractionists, who subscribed to an attitude of resistance to their pope.

In Antioch, Paul blamed Peter for not having discerned the impropriety of an obligation of the Jewish Law concerning the converted heathen. ${ }^{11}$ He summoned Peter for this error and confronted him. From the time of the Fathers of the Church and particularly the Latin Fathers onwards, exegetical efforts were directed to this verse. ${ }^{12}$ Medieval people might especially be familiar with the well-known contradictory interpretations advanced by Augustine and Jerome. While this caused no offense before the thirteenth century, the tone changed in the context of the Great Schism.

During the 1380 s, Henry of Langenstein and Honoré Bouvet both quoted the verse in order to appeal to the council as a forum of dispute settlement, in the style of the early stages of the Church. ${ }^{13}$ In 1395, a main text of the time, the Epistle of the University of Paris, then made Paul a figure representing the jus resistendi in front of Peter. ${ }^{14}$ In the same sphere of influence, Simon of Cramaud in 1397 affirmed that there could be no doubt: Paul was the patron of the Subtractionists: Faisons comme fit saint Paul à saint Pierre, ne resista-t-il pas in facie? Autrefois a esté preschée et pratiquée cette voye de sustraxion. ${ }^{15}$ The verbal adjectives selected refer to the imperative of a jus resistendi: Si papa faciat aliquid quod scandalizet Ecclesiam [...], resistendum esset sibi in facie sicut Paulus resistit Petro. ${ }^{16}$

10 On the same topic, see Izbicki, Authority of Peter and Paul; Posthumus Meyjes, Controverse tussen Petrus en Paulus; Posthumus Meyjes, Jean Gerson et l'assemblée de Vincennes; Posthumus Meyjes, Iconografie en Primaat; Froehlich, Fallibility Instead of Infallibility?; Froehlich, Biblical Interpretation. See also the old work of Overbeck, Über die Auffassung des Streits. For the Lutheran exegesis, see Lönning, Paulus und Petrus; Feld, Christus Diener der Sünde.

11 Galatians 2, 11: »But when Cephas came to Antioch, I made a protest against him to his face, because he was clearly in the wrong." The Bible version is Biblia sacra juxta vulgatam Clementinam, Rome-Tournai-Paris, 1938.

12 See Fédou, Jérôme, lecteur de l'épître aux Galates, 583.

13 Henry of Langenstein, Consilium pacis de unione et reformatione ecclesiae, ed. Du Pin, c. 830.; Honoret Bouvet, Somnium super materia schismatis, ed. Arnold, 89: Pape [...] ad instar Pauli qui Petrum inverecunde reprehendit?

14 Epistola Parisiensis (secunda), inc.: Sanctissimo in Christo Patri D. Benedicto divina providentia sancte romane ecclesie [...], Paris, BNF lat. 14643, fol. 49r-52r, fol. 49v (14 April 1395, edited 25 August 1395).

15 Simon of Cramaud, $1^{e r}$ Discours à l'assemblée du clergé, ed. Bourgois du Chastenet, 123.

16 Simon of Cramaud, De substraccione obediencie, ed. Kaminsky, 90-91. See Pierre Bertrand, Apparatus, on Ne Romani, Clem. 1.3.2., quoted ibid., 179 (from the manuscript Washington D. C., Catholic University, 195, fol. 152va): Unde si papa vellet totum thesaurum Ecclesie dare parentibus suis, aut Ecclesiam Sancti Petri destruere et facere palacium parentibus suis, aut eis dare patrimonium beati Petri, quod non licet, vel aliquid huiusmodi - non esset permittendum, sed esset ei resistendum et non obediendum, sine omni ipsius deposicione. 
At the heart of this attitude of resistance was one simple question: Cur ita facis?, a biblical reference to the Book of Job (9.12). Few authors evoked the sapiential origin of the question sent to the very God who announces in the Book of Job: Quis dicere potest: Cur ita facis? ,Who can say to Him: 'What are you doing? « What are you doing is to be understood as a condemnation of the will of the superior, which presupposes some courage. Cur ita facis? could thus become a syntagm for a refusal of the omnipotence of the prince, as much as a criticism of the discretionary and despotic power of the universal pontiff. ${ }^{17}$ The academics and other Subtractionists seized on it to justify a limitation of the plenitudo potestatis of the pope. Their gesture was all the more confrontational as the Dictatus papae, and later on the Decretum Gratiani and various theocratic arguments, had always asserted the opposite: the pope was indebted to nobody concerning his actions, he was accountable only to God, he was above discussion and could not be judged by anyone. ${ }^{18}$ We know the assertions of the theory elaborated by Boniface VIII in 1302, according to which »the pope is above any judgement, above any disapproval and above any criticism: Cui non est qui dicat, Cur ita faciat? «. ${ }^{19}$ Thus, the question extended beyond the simple interrogation to become a more general posture, that of the resistance to arbitrary absolute power.

From jus resistendi to jus appellandi

Through the course of the debates, the exegesis of the Paulinian verse demonstrated the importance of a doctrinal construction which was gradually refined: from the jus resistendi of the years 1395-1396, the theorists deduced a jus appellandi, a right of appeal which had been prepared by a sort of jus disputandi dealing with papal power and the precept of fraternal correction.

In 1404, Jean Gerson, then chancellor of the University of Paris, harangued Benedict XIII at Tarascon by giving a virulent sermon..$^{20}$ This text signaled the break, or at least the estrangement, of the chancellor with regard to the Avignonese Pope. The scene took place on January 1 st of that year. The restoration or restitution of obedience had only been attained a few months before. Now, the pope had to work firmly on the union, and everyone expected him to act. In this situation, Gerson evoked the controversy of Antioch between Peter and Paul in his long sermon, formulating questions in a unique and unprecedented manner. Three doctrinal questions were elaborated around the jus resistendi:

17 Cf. Congar, « Réception » comme réalité ecclésiologique, 374.

18 Among many examples, see Tancred, (1235), Gloss ad Comp. III, 1, 5, 3, quoted by Tierney, Foundations of the Conciliar Theory, 147: Nec est quid dicat ei, cur ita facis?; or Alvarez Pelayo ( $\nmid 1353)$, quoted by Jung, Un franciscain, 107: Successor Petri vicarius Jesu Christi vicem non puri hominis sed veri Dei gerens in terris [...] in omnibus et per omnia potest facere et dicere quicquid placet, auferendo etiam jus suum qui vult, quia non est qui dicit ei Cur ita facis?

19 Epistola Parisiensis (as n. 10), fol. 51r: Nam cum secundum doctrinam plurimorum jurisconsultorum, quod sepe nobis alias argutum est, papa sit suppremus judex Ecclesie, qui omnia dijudicat et a nemine judicatur et cui non est quid dicat cur ita faciat.

20 Jean Gerson, Sermo habitus Tarascone coram Benedicto XIII, ed. Glorieux, § 212, 64-90. 
Sed auget questionis admirationem (1) cur propter observationem circumcisionis et aliorum legalium Paulus restitit Petro in facie, cum tamen ipse quosdam circumciderit; (2) igitur quo pacto reprehendit ipse quod agebat, et praesertim superiorem in auctoritate, apostolatu seniorem et in gratia confirmatum die Pentecostes; (3) qualiter inculpat Paulus eum et jura non recte ambulasse ad veritatem evangelii ${ }^{21}$

(1) Why, because of the observance of the circumcision and the other Jewish laws, does Paul frontally resist Peter, while he, himself, had nevertheless circumcised some? (2) By what pact does he blame what he had carried out himself, and, especially, why does he face a hierarchical superior, his elder in apostolic terms, a man confirmed in the day grace of Pentecost? (3) How does Paul charge him and assert that Peter didn't walk in the evangelical way of the truth?

Gerson explained the resolution of the conflict: he thought that Peter had welcomed the reprimand with all humility and that neither had, therefore, sinned. ${ }^{22}$ But Gerson then argued for a fictional history: if Peter had resisted Paul to his face, refusing to agree, would Paul have withdrawn his obedience to Peter? Wouldn't he have obeyed? Would he have appealed to the Church council? Would this council have been above Peter or the opposite? Would Paul have resisted as his cardinal or as his equal? If Peter had excommunicated him, would he have been afraid? If Peter had persisted in his error, would he have lost the pontificate? Would he have been able to be deposed? By whom? How? Would a council have been able to be celebrated? And what would have happened if Peter had wanted to defend himself by armed force? ${ }^{23}$

Through this series of historical fictions, Gerson widened the reflection on a jus resisten$d i$, suggesting that the pope's stubbornness and pertinacity appealed to higher authorities. To put it another way, the right of appeal intervened when the resources of fraternal correction were exhausted. It is broadly apparent that, in spite of its use of exegesis, the subject was rooted in the most ardent questions of contemporary current events. All the themes of the moment were gathered here: the pope's stubbornness, his potential deposition, the authority of the council, the use of strength, the charge of heresy, the just reprimand and so on. In this debate, Gerson showed a lot of courage because, let us remember, the context is a sermon at Tarascon, in front of Pope Benedict XIII, just after the restitution of obedience.

21 Jean Gerson, Sermo habitus Tarascone coram Benedicto XIII, ed. Glorieux, 71.

22 Jean Gerson, Sermo habitus Tarascone coram Benedicto XIII, ed. Glorieux, 71: Qui tota sibi humilitate paruit; et ita neuter peccavit, saltem mortaliter. See also Pierre Plaoul, Discours de clôture des débats avant le vote, ed. Du Boulay, IV, 835, 836-843. Pierre Plaoul, Discours de clôture des débats avant le vote, ed. Du Boulay, IV, 843: Ideo Paulus Petrum reprehendit; nec propter hoc indignatus fuit Petrus.

23 Jean Gerson, Sermo habitus Tarascone coram Benedicto XIII, ed. Glorieux, § 212, 71-72: Quod si Petrus versa vice Paulo restitisset in faciem, nolens acquiescere, an Paulus se ab eo substrahere, an non obedire, an ad Ecclesiae concilium appellare potuerat? Si concilium in hoc superius erat Petro vel e contra? Si Paulus restitit Petro ut ejus cardinalis existens vel ut aequalem se deputans et nihil a Petro auctoritatis, sicut nec Evangelium suum recipiens? Quid, si de facto in Paulum excommunicationis sententias promulgasset, an eas Paulus timuisset? Quid si Petrus perstitisset in hoc errore, numquid eo facto papatum periderat? Quod si non, numquid deponendus tamen erat, et per quos et quomodo? An concilium sine eo potuisset in hoc casu celebrari? Quid si Petrus vi armata errorem suum defendere voluisset, numquid ipso etiam manente papa, vim vi licuisset repellere, aut verbis aut carceribus aut ipsa denique morte? Hieronymus praeterea et Augustinus, doctores eximii, cum discordent in hac materia, numquid alter eorum dicendus sit haereticus? Ille Paulum dispensative mentitum, hic Petrum juste reprehensum fuisse defendit. Porro cur in concilio de cessatione circumcisionis Petrus summus pontifex non tulit sententiam sed Jacobus. 
Yet by delivering this multiplicity of questions to the public sphere of the audience - and so to public debate - including Benedict XIII, Jean Gerson enabled a right of discussion concerning papal authority. ${ }^{24}$ He demonstrated how one could go about discussing Peter's power, de potentia Petri disputare and, as quoted at the outset of this article, reminded his listeners of the fact that theologians were used to debating divine truth. ${ }^{25}$ What Gerson thus denounced was the censorship, or self-censorship, of a reverential theology that discussed only in panegyric words. Furthermore, by speaking of an investigation (inquirere, perquirimus), he placed the ecclesiological and political debate on the footing of a theological search of a scientific type. It was not a question of being involved in controversy but of looking together, even if the appearances flirted with impropriety and with the transgression of certain tacit limits. ${ }^{26}$ Gerson encouraged the pursuit of an inquiry, increasingly asserting that nobody could know the truth of the moment nor the truth of the pope. He encouraged this inquiry not for speculative pleasure but for the sake of practical (that is to say a moral) edification: Non est disputationis speculativae actus sed aedificationis practicae. ${ }^{27}$

In his own way, by advocating the right of discussion and by encouraging the debate albeit a serene and specialized debate - Gerson thus did nothing but spread the Paulinian question to Peter: Cur ita facis? He defended the right of criticism by reflection. He defended the right to mature or thoughtful obedience, as opposed to blind obedience. In his interpretation, this right to discussion was attached to the right to resistance, a resistance to arbitrary power and omnipotence by way of reasoned criticism.

The words used by contemporaries thus managed to acquire a doctrine of appeal against the pope - an appeal to the council against the pope - and a critical resistance to power. I would go so far as to say that this doctrine implied the hypothesis of a double magisterium, that of Peter and that of Paul::28 Paul was seen to assure the doctrinal succession alongside Peter, who embodied the hierarchical succession. ${ }^{29}$ Paul's doctrinal arbitration was used to set him up as a paradigm of the theologian, the antonomasia of which paving the way for all other theologians. In this sense, theologians - including Gerson - as spiritual followers of the doctors, apostles and evangelists, were responsible for correcting the pope, as they were

24 See the quaestio of Jean Quidort, De potestate regia et papali, ed. Bleienstein, c. 22, 192-196: An licitum sit de huiusmodi pertinentibus ad papam disputare et judicare. Cf. also the later insistence: Tanto magis in talibus est veritatem inquirere, quanto periculosius esset in hoc non cognoscere veritatem. On this topic, see Briguglia, Inquirere veritatem, 13-14.

25 Jean Gerson, Sermo habitus Tarascone coram Benedicto XIII, ed. Glorieux, V, § 212, 72: Quid est igitur quod innuis mihi quasi non liceat de potentia Petri disputare? Nonne de omnipotentia Dei quotidie perquirimus?

26 Jean Gerson, Sermo habitus Tarascone coram Benedicto XIII, ed. Glorieux, V, § 212, 73: Quaestiones hujusmodi multiplicare magis et magis satagebat importune nimis studiositas speculatrix in meditatione mea.

27 Jean Gerson, Sermo habitus Tarascone coram Benedicto XIII, ed. Glorieux, V, § 212, 73.

28 On the semantics of 'magisterium‘, see Congar, Pour une histoire sémantique du terme magisterium; Congar, Bref historique des formes du «magistère» et de ses relations avec les docteurs, 103-104; Congar, Saint Paul et l'autorité de l'Église romaine.

29 See Marmursztejn, Autorité et vérité. 
responsible for the truth of the office of preaching: summus pontifex qui succedit Petro in apostolatu reprehendi potest publice per doctorem theologum qui in officio praedicationis succedit Paulo. ${ }^{30}$

We cannot draw the history of the exegesis of Galatians 2. 11 during the Great Schism to a close without including the refutations provoked by this new line of argument. In the pontificalist camp, from very early on Paul's resistance to Peter was seen as an irreverent (irrevecunde) resistance. ${ }^{31}$ From the beginning of its history, the Subtractionist exegesis of the Paulinian resistance had its detractors: the pope's advocates and the anti-Subtractionists. Not least among them, Nicolas Eymerich, for example, strove to refute the jus resistendi based on the premises of its elaboration in 1395. Seen in context, it was a question of reaffirming that Peter was positioned above Paul because of the delegations of mission he had received from Christ himself. ${ }^{32}$ As Nicholas argued, the papal statute was apart, that is to say beyond, the law. He defended the sacrosanct non-justiciability of the pope by anyone. ${ }^{33}$ Then followed the canonical and implacable argument: whoever resisted the established power resisted God, qui huic potestati a Deo ordinate resistit, Dei ordinacioni resistit. ${ }^{34}$

To sum up, the exegesis of the verse Galatians 2. 11 provided an occasion to spread and to specify the doctrine of the right of resistance against the supreme pontiff of the Roman Church, which was expressed in different ways: the right to discussion and disputatio, the right to criticism, the right to fraternal correction (law of fraternal correction), the right of reprimand, the right of appeal. About the ecclesiological constructions, then as in the time of the early Christians and again during the Gregorian period and the Investiture Contest, the rate of advance of the one was determined by the other.

Debating about reformatio

In the course of the debates, the reflections about the right to resistance against pontifical power became closely linked to reflections on the theme of reformatio, which also acquired the function of a check on absolute power. To contemporary thinkers, reformatio started to be seen as a way of building a limitatio of the pontifical plenitudo potestatis. Stimulated by the sphere of controversies, each of the ecclesiological positions within the debates, traditional or more innovative, then worked to establish an understanding of reformatio which corresponded its own doctrinal constructions.

30 Jean Gerson, Pro licentiandis in decretis, ed. Glorieux, V, 223: Ac perinde constituti sunt apostoli, discipuli et evangelistae tamquam doctores hujus legis, et ceteri successores eorum quos theologos nominamus, non secundum corticem litterae quae occidit, sed secundum interiorem spiritum qui vivificat; Jean Gerson, Sermon pour la fête des saints apôtres, ed. Glorieux VII/2, 722: Petrus praeest principatu, Paulus pollet magistratu totius Ecclesiae.

31 Honoret Bouvet, Somnium super materia schismatis, ed. Arnold, 89.

32 Nicolas Eymerich, Contra emissum in Conclavi per papam promissorum juramentum, Grenoble, Bibliothèque Municipale, 988, fol. 103r-117v, ici fol. 111v: Respondetur eis quod non Paulo sed Petro Christus claves dedit quod promisit cum ei dixit: 'tibi dabo claves regni celorum et quodcumque ligaveris etc', et Ecclesia clamittat non de Paulo sed de Petro stibi tradidit Deus claves regni celorumr. Et non Paulo sed Petro dixit Christus: >Pasce oves meas'. Petrus ergo non fuit subditus Paulo, sed Paulus Petro.

33 Nicolas Eymerich, Contra emissum in Conclavi per papam promissorum juramentum, Grenoble, Bibliothèque Municipale, 988, fol. 112r: Sic nec aliquis de Ecclesia potest sibi papam subdere et judicare.

34 Nicolas Eymerich, Contra emissum in Conclavi per papam promissorum juramentum, Grenoble, Bibliothèque Municipale, 988, fol. 112r. 
Carried by the debates, the long-term theme of reformatio acquired a new doctrinal and political status during the years of the council of Constance. In the years 1414-1418, and in particular from 1415 until 1417, the theme of reform was refocused. It regained the upper hand over other themes, such as union, peace, obedience or the truth of the pope. Treatises expressed this refocusing in their titles. Dietrich of Nieheim for example drafted a Super reformationem Ecclesie from the very opening of the council of Constance in December, $1414 .{ }^{35}$ Pierre d'Ailly announced his treatise De reformatione Ecclesiae in November, $1416 .{ }^{36}$ The former developed three themes which would gain particular prominence: the denunciation of vices in the papal system (tax system, exactions, reserves, benefits and curia customs); the election of an appropriate pope and the spiritual reform. Pierre d'Ailly, by contrast, intended to assign to the council a triple purpose regarding the past, the present, and the future. ${ }^{37}$ Its first task was to reform the deformation of the clerks (ad correctionem et reformationem ecclesiasticae deformitatis, quoad praeterita); then to aim for union (secundo, ad ordinationem et integrationem pacificae unionis, quoad praesentia) and thirdly, it should avoid future abuses and troubles (tertio, ad provisionem et evitationem maleficae pravitatis, quoad futura)..$^{38}$

That this program re-used extant formulations, for example authored in 1378 by Henry of Langenstein or Conrad of Gelnhausen, is known. ${ }^{39}$ Yet this re-use at the very heart of the Council of Constance transformed them into a real political program, and lent them a new breath and a new amplitude. Now based on a maturation of the minds, this program found its natural bed in Constance. Decades of debates and polemics on surrounding themes had been needed, but eventually the issue of reform emerged in 1414-1415, and became a center polarizing neighboring debates. Yet, for many, it was the council itself that brought reform. Many expectations and plans for a better future revolved closely around the reform-by-council. Altogether, we can note that the interpretation of reformatio as limitatio and its polarization of all aspirations were remarkable and ecclesiologically bold. By aiming to be limitatio, the reform authorized theorists to think of ecclesiological forms for notable counter-powers facing papal authority: the council, of course, but also the bishops, the cardinals, and, last but not least, the king.

35 Dietrich of Nieheim, Dialog aus der Kirchenreform, ed. Miethke and Weinrich, 296-305.

36 Pierre d'Ailly, Tractatus de emendatione Ecclesiae, ed. Miethke and Weinrich, 338-377.

37 Pierre d'Ailly, Tractatus de emendatione Ecclesiae, ed. Miethke and Weinrich, c. 922.

38 Pierre d'Ailly, Tractatus de emendatione Ecclesiae, ed. Miethke and Weinrich, c. 922.

39 Among many examples, cf. Conrad of Gelnhausen, Epistola Concordiae, inc.: Incipit Epistola ad dominum Karolum Regem Francorum in tractatulum sequentem... (mai 1380), Paris, BnF, 14643, fol. 88r-101r et fol. 244r-253v (second copy), ed. Bliemetzrieder, 116: Pro reformacione unitatis et pacis sacrosancte universalis Ecclesie expedit, potest et debet concilium generale convocari; ibid., 117: Est autem conclusio principalis ista, quod pro remediando et de medio auferendo scismate moderno expedit potest et debet concilium generale convocari ou encore Ergo forcius pro discussione moderni scismatis potest, expedit et debet concilium generale convocari; ibid., 119: Si ergo licuit et expediebat pro rebus temporalibus tunc curiam imperialem generalem convocari, longe forcius nunc debet concilium generale pro salute animarum et reformacione pacis tocius Ecclesie catholice convocari. See especially ibid., 138: Assumitur in argumento scilicet quod concilium generale absque auctoritate pape non debet congregari, est verum regulariter, potest tamen casualiter absque eius auctoritate convocari, et talis est casus noster [...]; Quod vero subditur papam esse maiorem concilio, dicitur quod in casu concilium est superius pape. 
The question raised by this development of diverging positions was, inevitably, that of veritas. Together with obedientia and reformatio, the word veritas saturated texts of the second phase of the Schism, and indeed helps to identify the affiliations and the camps. It was the signature of the ideological positions and informed about the identical allegiances. From the outset, veritas was seized by the pontifical rhetoric and, more profoundly, by the pontifical episteme. This regime of the truth, that is to say of a particular construction and meaning of the term, was developed by the pope and his jurists, who, fundamentally, thought of the Schism in terms of the truth or falsehood of one or both popes. This overarching logic governed their reactions, their discourses, their speeches, and their thoughts. Yet, the truth so understood remained a weapon of battle - the battle of the previous generation. It was, specifically, a battle without discussion. The episteme of a discourse of truth excluded all debate because of its dogmatism.

Very quickly, truth was set up as dogmatism on the papal side: there was the truth of the pope. This meaning drew its desire for inquiry and its desire for conformity from the inquisitorial customs. Moreover, it precluded legitimate discussion. The dogmatism of the truth necessarily neutralized debates. Some scholars still tried hard to remind readers of the uncertainty and unreachable nature of truth in this period of doubt, and encouraged them to avoid the stumbling block of blindness or sectarianism. It should also be noted that dogmatism was not the privilege of one camp - in this particular case the pontificalist camp - though it was, to be sure, more visible there. Yet the dogmatic attitude was diffusely present everywhere; it harked back to extremism in all camps, among the Parisian academics and among the papal canonists, among the theologians and among the jurists, both within the Roman obedience and within the obedience of Avignon.

This atmosphere must be explained by latent, symbolic and ambient violence, and having studied intellectual and discursive practices and the doctrinal contents inferred by these discursive practices - we may now attempt to grasp this atmosphere of the time by investigating its traces in the debates. Though the study of textual debates cannot tell us all about its contexts, debates are revealing of ambient violence as much as they are responsible for it. The atmosphere indeed seems to have been one of symbolic violence - of instances of unspoken censorship and intimidation. But this violence was also the subject of the debates, and could be denounced or channeled. We can grasp some of the dynamic of forms of symbolic violence in the discourse surrounding the University of Paris, which exhibited a considerable thirst for power and even for intellectual monopoly. Precisely because it was symbolic, the ambient violence became visible in silences in this situation, yet its furtive presence is not easily unmasked. The authors kept silent about it especially when it was heavy upon them. When they spoke about it, this means it was already mastered. We spot indications in the scruples, the confusion of the consciousness, the remorse, and the fears in particular, the fear of reprisals and score-settling, the climate of distrust and suspicion, criticism and slander, the calls for respect. The atmosphere was heavy with the unspoken, with censorship and intimidation.

In 1402, when the so-called Epistle of Toulouse was published, for example, it denounced the climate of terror provoked by the Subtractionists. Historians have gone so far as to speak about an "intellectual terrorism « imposed by the Parisian doctors. ${ }^{40}$ The Epistle of Toulouse, possibly drafted by Guigon Flandrin, in fact insisted on denouncing the com-

40 See Ourliac, »Epistola tholosana« 2, 563-578. 
pulsory, ever-present silence, the bringing-to-heel of the opposition after the vote of July, 1398 (that is to say the very important moment of the vote of Subtraction during the Third Assembly of the French Clergy): Tacuit enim post substractionis communiter non acceptae conceptum facta velut attonita [...]. The seal of silence reigned, sub sigillo silentii. ${ }^{41}$ From the beginning, the opponents were not able to make themselves heard. ${ }^{42}$ Worse, they were afraid for their own person and their own life, so that they left Paris - as we know to be the case for Gerson himself. ${ }^{43}$

What one can take away from the sources is the idea that this violence was the sign of an ongoing transformation, of a kind of growth crisis of the Parisian university world - a crisis of authority and of confidence. Violence thus related closely to the re-defining of a university identity, which was defined by three characteristics: first, access to a doctrinal autonomy; second, the will to participate in the supreme power; and third, the ambition of attaining a monopoly of control over public opinion.

The claim of doctrinal autonomy was to be formulated in the magisterium of Paul, the theologian, next to that of Peter, the institutional leader, as discussed above. Concerning the will to participate in the supreme power, the University gradually drew up a real political program to overcome the ecclesial crisis from the beginning of the 1390 s onwards. With the multiplicity of the texts that it published - letters, prescriptions, requests, gravamina etc. it intended to occupy the center stage in the critical hours from August, 1392 - critical for the pope, but also for King Charles VI. What it moved forward as an incomparable trump was the strength of its expertise. This expertise allowed the university to aspire to participation with considerable legitimacy. Its role was greatly transformed with this shift: the University would no longer be the authority of determination, as traditionally, but the authority of consilium. Pierre d'Ailly intended to exercise this expert role fully at the Council of Constance. The expertise of the prelates and the academics was not to be seen as interference in the respective others' sphere of influence, but as part of the free game of the debates. A proof of this was d'Ailly's indignation when, during the council of Constance, Maurice of Prague was forbidden to argue during a debate. D'Ailly rebelled against this; the role of the doctors and the theologians was not to silence disputationes but to highlight them. ${ }^{44}$ In a sense, the

41 Epistola tholosana, ed. Du Boulay, V, 5: Tacuit enim post substractionis communiter non acceptae conceptum facta velut attonita, afflictionem nedum sentiens, quasi praegnans verba sub sigillo silentii retinere voluit, ex substractione unionem pro partu promissam suspiriis inanibus multiplicatis expectans.

42 Epistola tholosana, ed. Du Boulay, V, 5: Praeterea quid loqui praefatae filiae vestrae profuisset cum a principio penitus audientia a contrarium opinantibus turbaretur.

43 Epistola tholosana, ed. Du Boulay, V, 5-6: Absque eo quod quidam ex illis qui per vos fuere ad concilium Parisiense evocati et qui habentes respectum ad Deum, bonum Ecclesiae, honorem vestrum et regni et qui vestrae majestati regiae secundum conscientiam et justitiam consulebant, non esse substrahendam obedientiam vero papae, Parisius esse non poterant, nec adhuc esse possent forsitan sine eorum maximo timore personarum et periculo.

44 Pierre d'Ailly, Tractatus de potestate ecclesiastica, ed. Du Pin, II, 950: Ad hanc conclusionem se sua humilitate responsurum exhibuerat venerabilis pater et egregius sacrae scripturae doctor, magister Mauricius de Praga et posuit tres conclusiones. [...] sed quidam veritatis adversarii, timentes ne per ipsum et deinde per quosdam alios sacrae theologiae doctores in disputationibus, aut determinationibus impugnarentur aliqui errores in hoc sacro concilio delati, conspiraverunt et procuraverunt dictam disputationem impediri. Contra quos publico verbo et scripto, ob reverentiam fidei protestatus sum, quod doctoribus sacrae theologiae maxime in concilio generali, ubi agitur de erroribus extirpandis, non debet inhiberi disputatio, aut scholastica determinatio, pro declaratione veritatis catholicae et reprobatione contrariorum errorum. Alioquin, qui de facto secus facerent, redderent se suspectos de fautoria haereticae pravitatis. Quia ergo dictus magister sic impeditus fuit ab hac responsione, ego hujus conclusionis nodum breviter explicabo. 
professional theologian was thus installed as a natural counselor of the powerful and a safeguard against abuse..$^{45}$ The theologian was meant to be an expert and therefore a careful man. He was portrayed as a wise person, the one that the councils have to summon, in brief the epieikeas. ${ }^{46}$

Finally, in the redefinition of its identity and its self-awareness, the University aspired, without saying this explicitly, to the monopoly over control of public opinion. This ambition towards a monopoly can be felt subtly in the debates. It accounts for some of the virulence of the violence, masked or admitted. One stake in all the debates, throughout the course of the emergence of the Schism, and in particular, during the course of Constance, was that of control over public opinion. The known forms of constraints and pressures would, on a certain level, not only have aimed at imposing the IUniversity line onto the politics of the kingdom, but also onto the listening public, which now exceeded the sphere of the masters and was that of ambient opinion, hence the care taken by the speakers to convince, and to convince by using all the tricks of rhetoric and logic, pathos and ethos. Masters became public figures, intellectuals in the public sphere, or to quote Daniel Hobbins's term, "public Intellectuals « ${ }^{47}$

Nevertheless, the outcome reconstructed by the historian uncovers the failure of this ambition, the missed dream of monopoly. The academics clearly lost their grasp on power within the period under discussion. Several signs betray this failure of their monopoly: the tension, the papers outside of the university which multiplied, the faintness of the university in general, its anger. As has been shown, the honor of the academics became so sensitive as to demand reparation for insults - for example, Jean Hayton had confronted the scholars in $1395 .^{48}$

Conclusion: the polemical approach to a new history of the Great Schism

The discussion of the Great Schism presented here has envisaged the debates as events of history, and even as decisive actors. It seems possible to investigate the debates in such a way as to bring light to the structural realities they shaped, showing the Great Schism in a new light.

First of all, the debates proved to be engines of discursive production, and built doctrines. Through the examples of the discussions surrounding jus resistendi, or reformatio, or veritas, it also emerges clearly that debates produced doctrinal discursivity. Words became markers, and these markers signaled respective positions. We might say that words acquired additional meaning, which might stabilize. To contribute to a new history of the production of knowledge at the time of the Great Schism, such processes can be reconstructed in a slow and patient historical reconstruction, one text at a time, one argument at a time, within a vast intertextual constellation.

45 On Gerson, see Lusignan, "Vérité garde le roy», $261 \mathrm{ff}$.

46 Jean Gerson, Tractatus de unitate Ecclesiae, ed. Glorieux, VI, § 272, 144-145.

47 Hobbins, Authorship and Publicity before Print, esp. 128-151 (ch. 5: The Schoolman as Public Intellectual). See also, for a later time, Small, Public Intellectual, especially Copeland, Pre-modern Intellectual Biography. See also Copeland, Pedagogy, Intellectuals and Dissent.

48 Requeste Universitatis facte Regi Francie [...], Paris, BnF, lat. 14643, fol. 52v., fol. 52v (sixth request): Sexta, quod scribat ad curiam romanam, ut magister Johannes Haconis ordinis Jacobitarum detineatur in carceribus donec errores suos correxerit, et injuriam regi, ducibus et universitati illatam reparaverit. See Destemberg, Honneur des universitaires au Moyen Âge, in particular ch. 9 (Emouvoir a justice: défense et restauration de l'honneur blessé); Destemberg and Kouamé, Aux origines de l'homo academicus, 45-55. 
Secondly, reconstructing debates in this way helps to unmask ecclesiologial and institutional games. The time of the Great Schism was indeed one of vast ecclesiological possibilities. The experiment of a subtraction of obedience became not only thinkable, but was officially applied. The ecclesiological alternatives to the monarchic government of the pope were thought through with unprecedented excitement. Everywhere, ideas about the forces of opposition, proposals of limitations to papal power, and incentives for a resistance to the full powers emerged. This period of debate was also a time of hopes for change. The uncertainties of the Great Schism also encouraged expectations of new openings and new solutions. Against this background, debates were able to set conditions for the actors of time. People were caught up in the disorder of this polemical atmosphere, and the debates decided on certain personal trajectories, and vice versa, as the great debaters of the time played their own games.

The proposed approach, which situates the history of the Great Schism in a perspective focused on its polemical culture, is a challenging one. Discourses and their textual practices are revealed as much, if not more, by the open controversies as by the silences hidden in the sources. Behind the debates, we must assume passions. By scrutinizing the sources, we can partly reconstitute them - the fears, the hatreds, the vindications, the surprises, the violence, the desires, the ambitions and the frustrations. ${ }^{49}$ Such emotions and feelings fed an atmosphere of factions and their convictions; the hour was, indeed, one of excess and extremism, of crises and emergency. Allegiances tightened. Camps hardened. Networks came to light. During the scope of one generation (1395-1418), the historian observes an ascent of sectarianism, fed by an amalgamation of the human passions with the polemism of circumstance. Far from being the privilege of one camp, the tension between dogmatism and resistance found its way into both factions. Hence the violence of this time of crisis, which remains to be researched further within the contexts of a historic anthropology of the intellectual violence of the medieval scholarly world. So far, the historicization of the ecclesiological debates of the time of the Great Schism seems to validate the hypothesis that ecclesiology and polemology remain intrinsically linked, and should be studied in the context of each other.

49 Sère, Débats d'opinion. 


\section{References}

Bernat, Chrystel and Bost, Hubert (eds.), Énoncer/dénoncer l'autre. Discours et représentations du différend confessionnel à l'époque moderne (Turnhout, 2012).

Briguglia, Gianluca, Inquirere veritatem. Osservazioni sui prologhi dei trattati politici di Giovanni di Parigi, Egidio Romano, Giacomo da Viterbo (1301-1303), Il Pensiero Politico. Rivista di storia delle idee politische e sociali 41 (2008) 3-20.

Broggio, Paolo, La teologia et la politica. Controversie dottrinali, Curia romana e monarchia spagnola tra Cinque e Seicento (Florence, 2009).

Burnand, Leonard and Paschoud, Adrien (eds.), Espaces de la controverse au seuil des Lumières (1680-1715) (Paris, 2010).

Büttgen, Philippe, Luther et la philosophie. Étude d'histoire (Paris, 2001).

Chenu, Marie-Dominique, Introduction à l'étude de Saint Thomas d'Aquin (reprint Paris, 2002).

Congar, Yves, Saint Paul et l'autorité de l'Église romaine d'après la tradition, in: Studiorum Paulinorum congressus internationalis catholicus (Rome, 1961) 491-516.

Congar, Yves, La " réception " comme réalité ecclésiologique, Revue des Sciences Philosophiques et Théologiques 56 (1972) 369-403.

Congar, Yves, Bref historique des formes du "magistère « et de ses relations avec les docteurs, Revue des Sciences Philosophiques et Théologiques 60 (1976) 99-112.

Congar, Yves, Pour une histoire sémantique du terme "magisterium", Revue des Sciences Philosophiques et Théologiques 60 (1976) 85-98.

Conrad of Gelnhausen, Epistola Concordiae, ed. Placidus Franz Bliemetzrieder, Literarische Polemik zur Beginn des grossen abendländischen Schismas (Vienna, 1910) 111-140.

Copeland, Rita, Pedagogy, Intellectuals and Dissent in the Later Middle Ages: Lollardy and Ideas of Learning (Cambridge, 2002).

Copeland, Rita, Pre-Modern Intellectual Biography, in: Small, Public Intellectual, 40-61.

De Franceschi, Sylvio H., La crise théologico-politique du premier âge baroque. Antiromanisme doctrinal, pouvoir pastoral et raison du prince: le Saint-Siège face au prisme français, 16071672, Bibliothèque des Écoles françaises d'Athènes et de Rome 34 (Rome, 2009).

De Libera, Alain, Analyses du vocabulaire et histoire des corpus, in: Jaqueline Hamesse et Carlos Steel (eds.), L'élaboration du vocabulaire philosophique au Moyen Âge, Actes du Colloque international de Louvain-la-Neuve et Leuven (12-14 septembre 1998) organisé par la s.i.e.p.m. (Turnhout, 2000) 11-34.

Destemberg, Antoine and Kouamé, Thierry, Aux origines de l'homo academicus. Les signes de distinction sociale chez les universitaires médiévaux, in: Jean-Philippe Genet and E. Igor Mineo (eds.), Marquer la prééminence sociale (Paris, 2014) 45-55.

Destemberg, Antoine, L'honneur des universitaires au Moyen Âge. Étude de l'imaginaire social (Paris, 2015).

Dietrich von Nieheim, Der Dialog aus der Kirchenreform - Eingabe, ed. Jürgen Miethke and Lorenz Weinrich, Quellen zur Kirchenreform im Zeitalter der großen Konzilien des 15. Jahrhunderts, Ausgewählte Quellen zur Geschichte des Mittelalters [38a] (second edition), (Darmstadt, 2015) 296-305.

Epistola Parisiensis (secunda), Paris, BNF, lat. 14643, fol. 49r-52r.

Epistola tholosana, in: César-Egasse du Boulay (ed.), Historia universitatis Parisiensis (Paris, 1673) Vol. 5, 4-24. 
Henry of Langenstein, Consilium pacis de unione et reformatione ecclesiae in concilio universali quaerenda, in: Louis Ellis Du Pin (ed.), Opera omnia Johannis Gersonii, Vol. 2 (Anvers, 1706) 809-840.

Fabiani, Jean-Louis, Dispute, polémiques et controverses dans les mondes intellectuels. Vers une sociologie historique des formes de débat agonistique, in: Christophe Prochasson and Anne Rasmussen (eds.), Comment on se dispute. Les formes de la controverse = Mil neuf cent . Revue d'histoire intellectuelle 25 (2007) 45-60.

Fédou, Michel, Jérôme, lecteur de l'épître aux Galates: l'héritage d'Origène, in: Isabelle Bochet and Michel Fédou (eds.), L'exégèse patristique de l'épître aux Galates (Paris, 2014) 133-154.

Feld, Helmut, Christus Diener der Sünde. Zum Ausgang des Streits zwischen Petrus und Paulus, Theologische Quartalschrift 153 (1973) 119-131.

Foucault, Michel, L'archéologie du savoir (Paris, 1969).

Froehlich, Karlfried, Fallibility Instead of Infallibility? A Brief History of the Interpretation of Ga. 2, 11-14, in: Paul Empie and Austin Murphy (eds.), Teaching Authority and Infallibility in the Church (Augsburg, 1980) 259-269 and 351-357.

Froehlich, Karlfried, Biblical Interpretation from the Church Fathers to the Reformation (Farnham, 2010).

Gay, Jean-Pascal, Morales en conflit. Théologie et polémique au Grand Siècle (1640-170o) (Paris, 2011).

Gay, Jean-Pascal, Lettres de controverse. Religion, publication et espace public en France au xviie siècle, Annales HSS 68/1 (2013) 7-41.

Hobbins, Daniel, Authorship and Publicity before Print: Jean Gerson and the Transformation of Late Medieval Learning (Philadelphia, 2009).

Honoret Bouvet, Somnium super materia schismatis, ed. Ivor Arnold (Publications de la Faculté des Lettres de l'Université de Strasbourg, 28), (Paris, 1926).

Izbicki, Thomas M., The Authority of Peter and Paul: The Use of Biblical Authority during the Great Schism, in: Thomas M. Izbicki and Joelle Rollo-Koster (eds.), A Companion to the Great Western Schism (1378-1417) (Leiden, 2009) 375-393.

Jean Gerson, Oeuvres complètes de Jean Gerson, ed. Palémon Glorieux, 10 vols. (Paris 19601973).

Jean Quidort, De potestate regia et papali, ed. Felix Bleienstein, Frankfurter Studien zur Wissenschaft von der Politik 4 (Stuttgart, 1969).

Jouhaud, Christian, Les pouvoirs de la littérature. Histoire d'un paradoxe (Paris, 2000).

Jouhaud, Christian, Mazarinades, la fronde des mots (Paris, 1985).

Jung, Nicolas, Un franciscain, théologien du pouvoir pontifical au xive siècle. Alvaro Pelayo, évêque et pénitentier de Jean XXII (Paris, 1931).

Lilti, Antoine, Querelles et controverses. Les formes du désaccord intellectuel à l'époque moderne, in: Christophe Prochasson and Anne Rasmussen (eds.), Comment on se dispute. Les formes de la controverse = Mil neuf cent. Revue d'histoire intellectuelle 25 (2007) 13-28.

Lönning, Inge, Paulus und Petrus. Gal 2, 11ff als kontroverstheologisches Fundamentalproblem, Studia Theologica. Scandinavian Journal of Theology 24 (1970) 1-69.

Lusignan, Serge, "Vérité garde le roy ". La construction d'une identité universitaire en France (xiiie-xve siècle) (Paris, 1999). 
Marmursztejn, Elsa, Autorité et vérité dans les relations entre la papauté et les docteurs parisiens au xiiie siècle, in: Gian Luca Potestà (ed.), Autorität und Wahrheit. Kirchliche Vorstellungen, Normen und Verfahren (13.-15. Jahrhundert), Schriften des Historischen Kollegs, 84 (München, 2012) 21-44.

Nagy, Piroska, Perrin, Michel-Yves, and Ragon, Pierre (eds.), Les Controverses religieuses entre débats savants et mobilisations populaires (Rouen, 2011).

Nicolas Eymerich, Contra emissum in Conclavi per papam promissorum juramentum, Grenoble, Bibliothèque Municipale, 988, fol. 103r-117v.

Ourliac, Paul, L'»epistola tholosana« de 1402, in: Mélanges offerts à Pierre Vigreux, Vol. 2 (Toulouse, 1981) 563-578.

Overbeck, Franz, Über die Auffassung des Streits des Paulus mit Petrus in Antiochien (Gal 2, 11) bei den Kirchenvätern (Basel, 1877, reprint 1968).

Pierre d'Ailly, Tractatus de potestate ecclesiastica, in: Louis E. Du Pin, Opera omnia Johannis Gersonii, Vol. 2 (Antwerp, 1706) 925-960.

Pierre d'Ailly, Tractatus de emendatione Ecclesiae (also known as De reformatione), ed. Jürgen Miethke and Lorenz Weinrich, Quellen zur Kirchenreform im Zeitalter der großen Konzilien des 15. Jahrhunderts, Ausgewählte Quellen zur Geschichte des Mittelalters [38a] (second edition), (Darmstadt, 2015) 338-377.

Pierre Plaoul, Discours de clôture des débats avant le vote, ed. in: César-Egasse du Boulay, Historia universitatis Parisiensis, Vol. 4 (Paris, 1665-1673) 835-843.

Piron, Sylvain, Contexte, situation, conjoncture, in: Florent Brayard (ed.), Des contextes en histoire. Actes du Forum du CRH, 2011 (Paris, 2013) 27-65.

Postel, Claude, Traité des invectives au temps de la réforme (Paris, 2004).

Posthumus Meyjes, Guillaume Henri Marie, De controverse tussen Petrus en Paulus. Galaten 2: 11 in de historie (Gravenhage, 1967).

Posthumus Meyjes, Guillaume Henri Marie, Iconografie en Primaat. Petrus en Paulus op het pauselijk zegel, Nederlands Archief voor Kerkgeschiedenis 49 (1968) 4-36.

Posthumus Meyjes, Guillaume Henri Marie, Jean Gerson et l'Assemblée de Vincennes (1329). Ses conceptions de la juridiction temporelle de l'Église (Leiden, 1978).

Requeste Universitatis facte Regi Francie (programme de l'Université au Grand Conseil), in: Edmond Martène and Ursin Durand, Thesaurus Novus Anecdotorum, Vol. 2 (Paris, 1717) cols. 1135-1136.

Sère, Bénédicte, Les débats d'opinion à l'heure du Grand Schisme. Ecclésiologie et politique, Ecclesia Militans 6 (Turnhout, 2016).

Simon of Cramaud, 1er Discours à l'assemblée du clergé (2nd December, 1406), in: Louis Bourgeois du Chastenet, Preuves de la Nouvelle Histoire du Concile de Constance (Paris, 1718) 118-124.

Simon of Cramaud, De substraccione obediencie, ed. Howard Kaminsky, Medieval Academy Books 92 (Cambridge, MA, 1984) 69-164.

Small, Helen (ed.), The Public Intellectual (Oxford, 2002).

Tierney, Brian, Foundations of the Conciliar Theory: The Contribution of the Medieval Canonists from Gratian to the Great Schism (Cambridge, 1955).

Thomas Aquinas, Super Epistolam ad Galatas lectura, ed. Raffaele Cai, Super Epistolas S. Pauli lectura (eighth revised edition), (Turin, 1953). 


\title{
Polemics investigated in a late fifteenth-century Fastnachtspiel (Shrovetide play)
}

\author{
Claudia Daiber*
}

The article analyses the polemics used in the Fastnachtspiel (Shrovetide Play) Der Juden Messias - in scholarship also known as Spil vom Herzog von Burgund - by the meistersinger Hans Folz (1435/40-1513), a barber-surgeon from Nuremberg. The play belongs to a group of Shrovetide plays within Folz's oeuvre which, under a religious cover, negotiates the given sociological divide in the city of Nuremberg between the Christian and the Jewish communities at the end of the fifteenth century. In its first part, the play systematically stabilizes the Christian side and destabilizes the other, i.e. the Jewish side by directing polemical attacks through the devices of self-accusation and self-flagellation by the Jewish characters. The effect is that the actions of the Christian side are legitimized and any moral hurdles towards condemning the Jewish characters are removed by ultimately equating them with feces and swine.

The second part contains a rather ambiguous message since on the one hand the ruler expressis verbis gives his permission to the mob, represented by the jester characters, to rob, rape and oust the Jewish characters. This consenting, on the other hand, prompts a uniting of the mob characters with the ruler. In other words, any moral authority of the ruler - who clearly is a metaphor for the later emperor Maximilian I - is put on a par with the mob and is therefore denied. Whether or not this latter message was appreciated by the city council of Nuremberg at the time remains an open question since there is, to date, no archival proof of the play's staging nor of its rejection.

Keywords: City of Nuremberg; sixteenth century city culture; Fastnachtspiel/Shrovetide Play; Anti-Judaistic polemics and agitation; criticizing the ruler; staging the Judensau

* Correspondence details: Claudia Daiber, University of Groningen, PO Box 72, 9700 AB Groningen, the Netherlands. Email: c.m.daiber@rug.nl. 


\section{Introduction}

This article rethinks the polemics used against »the Jews « in the drama text Der Juden Messias ${ }^{1}$ by the Nuremberg-based Meistersinger Hans Folz (1435/1440-1513). Folz, a barber-surgeon by profession, wrote strophes in the Meistersinger tone, obscene verses (mæren), and various other sorts of text in addition to his Shrovetide plays. ${ }^{2}$ Altogether, he left a rather comprehensive oeuvre which marks him as one of the most productive authors from the Germanspeaking lands on the threshold between the Late Middle Ages and the Early Modern Period.

A characteristic of his work is that his texts are not prudish in the choice of their words, the composition of their expressions, their performativity, or their messages. This observation, however, is not unique to Folz's work. It is a common feature of the genres he is most associated with, and it is an observation that can also be made with respect to comparable works by his contemporaries. Still, these features suggest that polemical attacks lie in wait. As a matter of course, polemics in the Western world have been employed since the times of the Greek polis, where they were understood to be part of rhetoric and therefore public political speech. ${ }^{3}$ Polemics continued to be used within patristic literature, which was greatly concerned with the constitution of the Christian church and therefore with its demarcation from pagan ${ }^{4}$ and heretic beliefs and also from the Jewish belief. ${ }^{5}$ Within this context, polemics were wielded as a weapon to attack those of other faiths, but were also used in order to unite Christians against an imagined enemy. It is a well-researched historical fact that throughout Europe, anti-Judaistic and even anti-Semitic resentment increased at the end of the Late Middle Ages ${ }^{6}$ and so did anti-Judaistic polemics. ${ }^{7}$ This phenomenon can, amongst others, be traced in the religious play, and particularly in the passion play, a widespread medium in the German-speaking lands during the fifteenth and early sixteenth centuries. ${ }^{8}$ That Folz was familiar with this genre and its anti-Jewish apologetics and polemics can be assumed not only on the grounds of his general participation in this contemporary discourse but also because he makes an explicit statement to that effect in his Fastnachtspiel entitled Kaiser Constantinus. ${ }^{9}$ As he states in the play's epilogue: Und habe euch drum ein geistlichs gemacht..$^{10}$ With this statement he expresses his intention of having composed a "religious « Fastnachtspiel, an intention which he realized in three plays, one of which is Der Juden Messias, the object of investigation of this analysis.

1 The play will be referred to in this analysis with this title; another title referring to the same play more commonly used in scholarship is Spil vom Herzog von Burgund. The reason for this choice is that the play will be quoted first according to the edition Der Juden Messias, ed. Przybilski. In addition, quotes will refer to the still-used outdated edition ein spil von dem herzogen von Burgund, ed. von Keller.

2 Janota, Folz, 770.

3 Stauffer, Polemik, 1405.

4 The term "pagan« derives from the Latin word paganus which literarily means someone living in the countryside. During the fourth century, when Christianization took place within the Roman Empire due to the Constantinian shift, the term referred exclusively to persons neither adhering to the Jewish nor to the Christian faith.

5 Stauffer, Polemik, 1406 and for an analysis of polemical attacks against each group, see Opelt, Polemik in der christlichen lateinischen Literatur, 208-228.

6 See Ben-Sasson, Middle Ages, 574-592.

7 See, for example, Mittlmeier, Publizistik im Dienste antijüdischer Polemik, 101-133.

8 See Rommel, Judenfeindliche Vorstellungen, map no. 14 (without page numbering).

9 Janota, Folz, 780.

10 Janota, Folz, 780. 
The genre of the Fastnachtspiel is the representation of the profane drama of the Late Middle Ages and the Early Modern Period in the German speaking lands, and Nuremberg was one of the spots where such a literary tradition established itself. ${ }^{11}$ Besides Folz, we know two further major names in this tradition of "craftsmen-poets « hailing from the city of Nuremberg: Hans Rosenplüt (1400-60) ${ }^{12}$ and Hans Sachs (1486-1576). ${ }^{13}$ Since craftsmanship as the primary means to earn one's livelihood only existed within cities, this tradition could only develop within a city culture.

Already, this tentative sketch shows that polemical language is neither restricted to a certain form nor medium nor field, but is purpose-driven. Additionally, the sketch displays the obvious: that polemics are embedded in historical circumstances. Therefore, the analysis will not only investigate the nature, manner and direction of the attacks launched by the play, but will also connect them, where this can be substantiated, with findings by historical science.

Furthermore, an analysis of which dynamics of the text can be grasped at the interface between text and recipient will be undertaken. This approach is based on the notion that a performative text contains an inherent program as to how it is to be received. In other words, a performative text directs and constitutes its own reception and - if it is successful in doing so - constitutes realities in collaboration with its imagined historical recipients. ${ }^{14}$ In particular, when researching the emotions evoked by the text, both the play's inherent program and the constituting of possible realities at the interface with the "recipient ", will be investigated since they are both pivotal in the construction of the Self and the Other, which again is decisive in the workings of polemics.

Although this approach of unlocking the knowledge contained in the performativity of the text basically functions without the actual historical recipient, it still triggers the question of whether the play underwent a historical performance or was otherwise received. To date, archival proof that this specific play has been performed in the city of Nuremberg or elsewhere does not exist. In the Wolfenbüttel manuscript which is relevant for its dating, ${ }^{15}$ the play's title ${ }^{16}$ reads Von dem hertzog von Burguny von der juden messias vnd wie jn Sibilla vertrib kurtzweylig zuo hören. ${ }^{17}$ The opening scene of the play elaborates further on this title when it explains the play's purpose and its fictitious occasion, which is to entertain the young Duke of Burgundy, the son of the Roman King Maximilian, on his visit to Nuremberg during the carnival season..$^{18}$ To assume, based on this reference in the text, that the play was in fact performed during a visit in $1491^{19}$ by the then German-Roman King Maximilian is,

11 Wuttke, Nachwort 441 and 451-452.

12 Glier, Rosenplüt.

13 Könneker, Hans Sachs, 60-69.

14 For both forms of performativity, see Velten, Performativitätsforschung, 552.

15 See Przybilski, Anhang 194, with reference to: Wolfenbüttel, Herzog August Bibliothek, Cod. Guelf. 18.12. Aug. 4.

16 See Der Juden Messias, ed. Przybilski, 85 at no. 1.

17 "Of the Duke of Burgundy, of the Jews' Messiah and how ১Sibilla chased him out, an entertaining play« (translated by the author).

18 [...] Das der jung herzog von Burgun, / Des romischen konigs Maximilian sun / Vnser genedigster herr, itz kumpt, / [...] / die vasnacht hynn bey euch zu sein [...]. Der Juden Messias, ed. Przybilski : 1. 8-10, 12; Ein spil von dem herzogen von Burgund, ed. von Keller, 1. 9-11, 13, p. 177.

19 The actual occasion for Maximilian's stay in 1491 in Nuremberg was the coming together of the Imperial Diet (Reichstag). 
however, problematic..$^{20}$ Still, this reference is decisive when dating the play's date of origin, between 1486, when Maximilian received the title of German-Roman King, and 1493, the final date of the manuscript.

\section{The conviction of the Jewish messiah and his trial}

The play Der Juden Messias contains various scenes negotiating different topics that are all connected to one story, which is the Duke of Burgundy's encounter with the "Jews" in the city of Nuremberg, including their Messiah who is revealed as a representation of the Antichrist. This observation already marks the play's complex structure and distinguishes it from the more simple form of the Fastnachtspiel, which was a serial play ${ }^{21}$ common during the fifteenth century. In this type of play the individual scenes did not necessarily connect to a narrative whole, but were connected through a meta-theme such as amour, martial conflict, or swindle.

To reveal the narrative whole, i.e. the plot and the accompanying discourses, what follows is the analysis of the topics in their chronological order.

\section{The hegemonic claim to space}

The first entry belongs to the male jester who - in the established style for this type of play - requests attention. The second entry belongs to the herald who declares what the play's occasion is - in this case, the visiting of the city during the carnival season by the "young Duke of Burgundy ", who is a character in the play. ${ }^{22}$ Both the herald and the jester mark the beginning of the play and therefore the enactment of its fictitious world. The character of the jester additionally indicates the arrival of the carnival season.

The next entry introduces the female prophet "Sibilla «, ${ }^{23}$ accompanied by her virgins and a female jester. The Duke recognizes the extraordinariness of her appearance and therefore inquires about it. She informs him that Jewish rabbis are spreading the word that their Messiah has appeared ready to take over the world's supremacy from the Christians, and therefore ultimately from the Duke. However, within the same scene, "Sibilla" reassures the Duke that she is unable to observe such a change of the world order in the celestial movements and that the Jewish rabbis are therefore telling lies, which she will make obvious.

20 For details, see Wenzel, "Do worden die Judden alle geschant«, 237-238. It may be of interest within this context that Folz wrote a poem (Spruch) about this stay by Maximilian in Nuremberg (see Janota, Folz, 788). In this poem he describes the visit with a gesture of praise, stating, however, upfront that he was not a witness of this event and that he relied on a printed source when composing his poem with the title Von der collacio vnsers aller gnedigiste hern vn romische kunigs maximilia in nureperg zu gericht (see Hans Folz, Reimpaarsprüche, ed. Fischer, XXIX). He describes in this poem, amongst other things, a Fastnachtspiel which was obviously performed during Maximilian's stay (see Hans Folz, Reimpaarsprüche, ed. Fischer, 326, 1. 271-307). His description and therefore the content of this Fastnachtspiel do not coincide with Der Juden Messias. Its plot was obviously the traditional motive of amour. It may be assumed that Folz, business-minded and eager for glory as he was, would have mentioned the performance of his Fastnachtspiel.

21 See Wuttke, Nachwort, 444 who uses the term »Reihenspiel«.

22 See Wuttke, Nachwort , 444 and at Velten, Performativitätsforschung, 552.

23 See Przybilski, Kommentar, 161 on the reception of Sibylline literature. 
This staging ${ }^{24}$ lays down one of the major discourses of the play, which is the Jewish characters' potential to form a threat to the existing Christian order and, therefore, in particular to the Duke, who is a representative of that order, but also that they - the "Jews" - are doomed to fail.

After "Sibilla" ['s] reassurance - which is underpinned by a claim of truth - a group of Jewish characters appears, including the »Messias«; three »Rabi«[s]; and a fourth, probably not very favorable looking character labeled »Schallat Jud « ${ }^{25}$. The latter speaks up first, followed by one of the three rabbis:

\section{Weicht auß, tret vmbe vnd ruckt von stat! [...] \\ Ir cristen, do tret an ein ort, \\ Weycht in die winkel da vnd dort \\ Vnd laßt vns auch herschen ein weil, [...] \\ Dann ruckt zusamen vnd macht weit! $!^{26}$}

Step aside [...]

you Christians stay in one spot

Move into the corners

Let us also be in command for a while [...].

Move closer together and make room.

In unmistakable terms the Jewish rabbis are requiring more space for themselves, which consequently means less space for the Christian characters. Through these utterances, the stage becomes the world conquered by the "Jews « and in this world the Christians are pushed to the corners (winkel). In other words, the Jewish characters are expressing a hegemonic claim and therefore control and sovereignty in the same way as it, in their view, has been exercised hitherto by the Christians.

The jester is the one character who immediately reacts to this claim by questioning it, picking up the key term for the Christians and reacting likewise in spatial terminology:

Wolst du vns all in die winkel jagen,

Ge dannen, das dich schut der rit ${ }^{27}$

You wanna push us into the corners

Bugger off right away.

24 With reference to Fischer-Lichte, Performativität, 55-56, the term "staging " [Inszenierung] is here understood to mean everything which can be fixed prior to the actual performance [Aufführung]. For example, the time, length and mode of acting; likewise appearances, space, light and text are fixed. In other words, it means within this context, everything which is can be retrieved from the play text or other historical sources without having actual knowledge about a historical performance.

25 For an explanation of this term, see: Przybilski, Kommentar, 163.

26 Cf. , Der Juden Messias, ed. Przybilski, 1. 85, 88; 1. 94-96, 1. 101; Ein spil von dem herzogen von Burgund, ed. von Keller, 1. 28, p. 171; 1. 1. 9, p. 172.

27 Cf., Der Juden Messias, ed. Przybilski, l. 104 and l. 117; Ein spil von dem herzogen von Burgund, ed. von Keller, l. 12 and 25, p. 172. 
The rhetoric by the jester already anticipates that the "Jews " will be chased away in the end, an announcement that decreases fear and theatrical tension since it already signals unmistakably the intention of the play, i.e. to secure the Christian group and to create a We.

This first aggregate of scenes evokes a threat to the existing order and stages this threat through spatial vocabulary, which suggests a corresponding spatial choreography. The emotion that is triggered is that of aggression, which is expressed by performative vocabulary on both sides. As a consequence, the hegemonic claim to power and control is intensified on both sides, equating the hegemonic Other and the religious Other simultaneously.

\section{The dragon uncovered as "Entcrist"}

The interaction between the Christian side and the Jewish side continues, with the jester as the leading character on the Christian side. Quite clearly as a reaction to the jester's brute words regarding the messianic and hegemonic claim of the Jewish side, one of the rabbi characters falls to the feet of the "Messias" and asks him for a sign to awe the people:

Laßt pald ein zeichen werden schein,

Vnd macht dem volk ein wenig forcht. ${ }^{28}$

Send a sign soon,

With which to awe the people.

This need for a sign of power and the desperation displayed by the rabbi character are indications of the creation of an atmosphere wherein Christian superiority is expressed by ridiculing and mocking the Jewish side, their Messiah as well as their claim to hegemony. In the fictitious world of the play, this sphere is strongly backed up by the aforementioned prophecies by the Sybil character that, according to the storyline and the staged choreography, are unknown to the Jewish side but are, of course, known to the recipients. Therefore, the segregation of the two groups into the Other and the We is pushed further by giving the Christian side a knowledge advantage over the Jewish side.

Upon this request by the aforementioned rabbi, a fire-spewing dragon appears:

Hie get ein trach vnd speyt feur au $\beta^{29}$

There comes a dragon and breathes fire.

From an entertainment point of view, the appearance of any dragon creature on stage is, of course, a welcome trick in any play, and in particular in a Fastnachtspiel. How does the text imagine this fire-spewing dragon? Again, the jester is the first to react to its appearance:

28 Cf. Der Juden Messias, ed. Przybilski, 1. 133-135; Ein spil von dem herzogen von Burgund, ed. von Keller, l. 9-11, p. 173.

29 Cf., Der Juden Messias, ed. Przybilski, 1.137; Ein spil von dem herzogen von Burgund, ed. von Keller, l.13, p. 173. 
Pox grint, was teufels pist dan du?

Seh einer dem schnoden merwolf $z u^{30}$

Yuck, what a poxy scab-face, what kind of devil are you?

Look at this despicable wolf from the sea.

He calls the dragon creature "a devil« and points to its ugly appearance because it has a skin with an uneven surface. ${ }^{31}$ Although the first part of the sentence may be taken as colloquial interjectional cursing, the jester denominates, or even recognizes, the dragon creature as an incarnation of the devil, hereby receiving a widespread medieval interpretation of Apocalypse 12. 9..$^{32}$ The jester's further naming of the creature as a "schnoden merwolf" is also in line with this tradition: the "merwolf" refers to a beast arising from the sea like the seven-headed beast in Apocalypse 13. 1, which is interpreted as being a symbol for the Antichrist receiving his powers from the devil who - according to this tradition - uses the incarnation of a dragon. ${ }^{33}$

Even more revealing is the adjective added to describe this creature: schnoden. This word probably has to be read as the German word schnöde, as it is most often used in the German language in the expression of der schnöde Mammon, a Biblical expression (Matthew 6. 24, Luke 16. 9-13) referring to the personification of riches and greed in the form of a false god, which, therefore, is despicable. ${ }^{34}$ Accordingly, the dragon is an abject but likewise pitiful creature, adding to the ridiculousness of the Jewish side.

The staging suggests that "Sibilla« comes to the front. She addresses the trach (dragon) directly with the deictic "you«:

Ich pewt ${ }^{35}$, dir, trach, bey Jhesus crafft,

Das von , dir nit hie wird geschafft,

Dann das $>d u$ sitlich weichest $a b$,

[...]

Dan eins bescheid mich, ob >dußr pist:

Sag, warumb heist $>$ dur der endtcrist? ${ }^{36}$

30 Cf., Der Juden Messias, ed. Przybilski, l. 138-140; Ein spil von dem herzogen von Burgund, ed. von Keller, 1. 14-15, p.173.

31 In general the word "grint « was used to denote a skin disease on the head in the form of a scab/rash most likely leading to scars and similar phenomena (see Deutsches Wörterbuch von Grimm, Keyword: grind, 2, letters a and b). In this context it means the uneven surface of the dragon's skin.

32 Emmerson, Antichrist in the Middle Ages, 22.

33 Emmerson, Antichrist in the Middle Ages, 22.

34 Seebold, Kluge Etymologisches Wörterbuch, 594 and 820.

35 Probably understood as a swearing phrase meaning: "I command you, dragon, by Jesus' own force." See for comparable contexts and a corresponding understanding: Meyer, Jacob Grimm, Deutsche Mythodologie, ed. Meyer, 499-500 and Nöcker, vil krummer urtail, 261 (Ich peut dir hie pei deim preller).

36 Cf., Der Juden Messias, ed. Przybilski, l. 142-144, 150-1; Ein spil von dem herzogen von Burgund, ed. von Keller, : l. $17-19,26$, p. 173. 
I command 'your, dragon, by the power of Jesus,

That syour will not accomplish here

Since syou are deviating

[...]

Tell me whether syour are the one:

Tell us, why do syou< call yourself »endtcrist«?

This passage, and in particular the last sentence where the trach is addressed as endtcrist, reads that the trach and the endtcrist are one and the same entity. Since the endtcrist and the "Messias" are also one entity, the text suggests that the three characters are staged by one person.

Assuming this personal union, the performative knowledge of the text reveals a heavy polemical attack since it views the Jewish Messiah as in essence being of deceit, something which is proven by the triple identity and has already been hinted at by the jester when he does not call the dragon creature what it is announced to be: a fire-spewing dragon. Rather, proleptically, he reveals it for what it is: a companion of the devil, namely the Antichrist who only aspires towards material goods, and so evokes the Christian side's emotion of disgust and disdain even more.

Antichrist traditions of the Middle Ages have styled the Antichrist as a figure mimicking and therefore parodying Christ, thus the Anti-Christ claims to be Christ but is not Christ that is his deceit. ${ }^{37}$ The text receives this tradition when the "Messias "/trach/endtcrist, in his subsequent religious dispute with "Sibilla «, tells the lie that he is descended from the lineage of David (like Christ) whereas he is, as "Sibilla" knows, from the lineage of Dan. ${ }^{38}$ When "Sibilla " further inquires about "the length of his reign" (Nu sag, wie lang wert dein gewalt ${ }^{39}$ ), he claims to rule in eternity, a pretension which is also signaled by his telling denomination endtcrist meaning - according to his own explanation - the end of Christendom. ${ }^{40}$ When "Sibilla« asks for proof regarding this assertion, he is obviously unable to provide it because one of the rabbis then steps forward and gives his and the others' lives in pledge if it is not proven that the character in question is the true Messiah.

\section{The wheel of fortune}

Following up on the earlier pledge by the Jewish rabbi, the "Messias" character suggests consulting "the wheel of fortune" (gluckßrat) $)^{41}$, in order to continue the evidence-taking procedure and thus the further pursuit of his hegemonic claim. As expected, the wheel of fortune reacts in favor of the Duke. When the Jewish side collectively recognizes that they have fallen prey to a Ifalse Messiah, they react with despair, disdain, and death threats towards their »Messias ${ }^{42}$

37 Emmerson, Antichrist in the Middle Ages, 40.

38 Emmerson, Antichrist in the Middle Ages, 46.

39 Der Juden Messias, ed. Przybilski, l. 171; Ein spil von dem herzogen von Burgund, ed. von Keller, l.15, p. 174.

40 For further explanations, see: Wenzel, »Do worden die Judden alle geschant«, 243-244.

41 Der Juden Messias, ed. Przybilski, 1. 224; Ein spil von dem herzogen von Burgund, ed. von Keller, l. 2, p. 176.

42 See, Der Juden Messias, ed. Przybilski, l. 231-252; Ein spil von dem herzogen von Burgund, ed. von Keller l. 9-30, p. 176. 
In the fictitious world of the play, however, they not only recognize their failing, but also recognize that the Christian side is in the right, in particular when the fourth rabbi character states: Sibilla, $d u$ hast recht geseit ${ }^{43}$ /, i.e.: "Sibilla, your prophecy is right."

This realization by the Jewish side marks a new way of constructing the Other. Generally, in polemics, the Other is constructed by attacking them. In this way, the Other is first identified and then - if the attack is successful - destroyed. In this scene the rabbis attack their "Messias" who, from their perspective, has become a »false« Messiah. Even more so, they expressively agree with the accusation by »Sibilla« against the Messiah character. By doing so, the rabbis transgress the border of the Christian We and are therefore no longer the Other. Since the text signals a transgression, even a surrender of the Jewish side, it is conceivable that the text would have reacted with the offer of baptism, thereby institutionalizing the transgression. Such scenes are depicted in the twelfth-century Ludus de Antichristo ${ }^{44}$ and in the fourteenth-century Frankfurt Directive Scroll ${ }^{45}$. During the Early and High Middle Ages, this possibility of baptism existed in the hope of Christian salvation for the Jewish believers. ${ }^{4}$ A weak reminiscence of this attitude can be discerned in the Fastnachtspiel Kaiser Constantinus $^{47}$ and in the Fastnachtspiel Die alt und neu ee, ${ }^{48}$ likewise belonging to the abovementioned group of the three "religious " Shrovetide plays by Folz.

As a consequence, the play continues by letting the Jewish characters concentrate on the wrongdoing of the character they have considered to be their Messiah and on the disgrace brought by him upon the Jewish community as a whole. Wenzel therefore correctly describes this scene with the term self-flagellation, an attack directed against the self, but evoked by the (here Christian) Other. ${ }^{49}$

This scene has a victorious atmosphere since the evidence is delivered. As a gesture of gratitude, the Duke passes on his jurisdiction to "Sibilla" for her uncovering of the "Messias'" treacherous and therefore false identity.

\section{The drinking competition}

Contrary to the rabbis, the Messiah character refuses to acknowledge his defeat and, therefore, the supremacy of the Duke and the prophetess "Sibilla". It is then her turn again, or rather she takes the initiative for a further challenge in the evidence procedure on whether or not the "Messias" character is the Messiah, i.e. the one to save the world and assume supremacy. She suggests that she and her virgins enter into a drinking competition with the "Messias". If he manages to hold his liquor, her side will believe that he is the »true« Messiah:

43 Der Juden Messias, ed. Przybilski, 1. 250; Ein spil von dem herzogen von Burgund, ed. von Keller, l. 27 , p. 176.

44 Ludus de Antichristo, trans. Engelsing, 1. 361-371.

45 Janota, Frankfurter Dirigierrolle, 1. 368-9.

46 Müller, Geschichte der Juden in Nürnberg, 35.

47 Kaiser constantinus, ed. von Keller,796-819.

48 Ein vasnachtsspil ed. von Keller, 1-33.

49 Wenzel, »Do worden die Judden alle geschant«, 246. 
Es sei dann, das du trinkest mit mir

Eins wein $\beta$, den ich selbs trincken thu

[...]

Vermagst du dann auß eigner krafft,

Das es kein schaden an dir schafft,

So woll wir all gelauben das,

Du seist der warhaft Messias ${ }^{50}$

Provided that you drink with me

Wine which I drink myself, too

$[\ldots]$

Are you then able to show on your own

that it does not harm you,

we shall believe

that you are the true Messiah.

This scene, like the previous wheel of fortune scene, presents its evidence by a judgment which is a persiflage to divine judgments, from which city law at the end of the sixteenth century had long since emancipated itself. ${ }^{51}$ When viewed as a valid evidence-taking procedure, the drinking contest is an attack against the Jewish population since they were exempt from evidence by divine ordeal since Frederick II, ${ }^{52}$ or to put it differently: they did not have to swear by referring to the Christian God.

More than this aspect however, the scene connects to the (surviving) popular custom of drinking someone under the table, which has, of course, a great staging potential. Since a significant feature of the genre is the reversal of hierarchies, the play at this point seems to break through a gender pattern, i.e. that a woman invites a male person to enter into a drinking contest with her, which is a challenge to his masculinity, and - in the event of losing - a denial thereof. As expected, the »Messias « character falls drunken and bloated to the ground:

Messias trinckt, laufft vnd geschwilt vnd fellt hin. ${ }^{53}$

Messias drinks, walks and bloats and falls down.

The competition is won by "Sibilla", something which has to be imagined as a highly entertaining performance. It is, however, questionable whether "Sibilla« is therefore raised to a higher, or even male, standard at any point; conversely, it rather seems that the Jewish "Messias" character is further lowered, i.e. even below women. A further potential for laughter is to see the "Messias" - who is supposed to be the savior of the Jewish community and the future ruler of the world - inebriated and out of control in every way. It is a state with

50 Der Juden Messias, ed. Przybilski, 1. 280, 283-286; Ein spil von dem herzogen von Burgund, ed. von Keller, 1. 28-9, 31-34 p.177.

51 Nottarp, Gottesurteilstudien, 192-194.

52 Nottarp, Gottesurteilstudien, 194. In 1236 Frederick II expanded the Worms Privilege, according to which the Jewish population within the Empire could deliver evidence in legal proceedings only by oath or witnesses, thus excluding divine ordeal.

53 Der Juden Messias, ed. Przybilski, 1. 303; Ein spil von dem herzogen von Burgund, ed. von Keller 1. 17, p. 178. 
which the Christian Messiah - who within the play's paradigm is the mental prototype - is never associated, and therefore proves moreover that this character is a false Messiah. In addition, the drunk and false "Messias « character ridicules the Jewish community even more when compared with the rather serious insight the Jewish rabbis show with respect to this defeat, which they have appropriated beforehand as their defeat. Accordingly, they react by displaying vicarious embarrassment:

ann ewig muß wir uns forder schamen ${ }^{54}$

For eternity we have to be ashamed for you.

The expression of shame is pivotal for further aligning the perspective of the play towards the self-flagellation of the Other, a rather subtle technique of attacking the Other and further evoking the emotion of superiority with the in-group.

Quite fittingly, as a reaction to the drinking behavior of the "Messias " character, the female jester introduces the word sau (female swine) for the first time into the play: So, saw, so fass gar au $\beta !^{55}$ The jester utters that he would have preferred it if the false Messiah were to be hanged beyond the city walls: $D u$ werst mir lieber am galgen dau $\beta^{56}$. Again, they are anticipating things to come.

The reawakening of the false "Messias" and his confession

Following up on the jester's speech expressing discontent, "Sibilla" asks the Duke's permission to make the false "Messias « reawaken to prevent him from escaping and to definitively label him as "Endecrist ${ }^{57}$

Sibilla dicit Fursten

Herr, ob ich mit im wurcken thu

Ein genad vnd mach in wider leben,

Auff das er vns tu antwort geben,

Was in zu der pubrey bewegt,

Deucht mich nit vbel angelegt. ${ }^{58}$

Sibilla says to the Duke:

Sir, shall I act gracefully on him and make him alive again.

So that he answers what was his motivation for this roguishness

This seems a good plan to me.

54 Der Juden Messias, ed. Przybilski, 1. 318; Ein spil von dem herzogen von Burgund, ed. von Keller, l. 31, p. 178.

55 Der Juden Messias, ed. Przybilski, l. 305; Ein spil von dem herzogen von Burgund, ed. von Keller, l. 18, p. 178.

56 Der Juden Messias, ed. Przybilski, l. 307; Ein spil von dem herzogen von Burgund, ed. von Keller, 1. 20, p. 178.

57 Der Juden Messias, ed. Przybilski, l. 342; Ein spil von dem herzogen von Burgund, ed. von Keller, l. 23, p. 179.

58 Der Juden Messias, ed. Przybilski, l. 326-331; Ein spil von dem herzogen von Burgund, ed. von Keller, l. 8-12, p. 179. 
This act by the prophetess may not be unproblematic to a critical mind since by doing so she blasphemously puts herself on the same level as Christ and as the Antichrist as well who, in his mimicking of Christ, is awakening the dead, too. ${ }^{59}$

What follows is a 36-line speech by the Jewish Messiah/false "Messias «/»endecrist «" wherein he confesses his (and therefore, likewise, the Jewish community's) crimes. This is a sculmination of anti-Jewish agitation in the form of self-flagellation and comprises the confession of deprivation of Christian property, murderous actions by Jewish physicians, robbery of Christian children, Jewish hate against Christians, and last but not least, usury, which is of particular relevance in the continuation of this play. ${ }^{61}$

What is the purpose of this "confession", in which the play - in the plainest way possible - processes prejudices that are all part of contemporary anti-Judaistic discourse ${ }^{62}$ In anticipating the punishment to come, this passage evokes tension and excitement from a staging perspective. From a procedural perspective, this plea of guilt is the precondition for the trial and its verdicts to come, including their execution. The self-accusation clarifies for the recipient that hate and envy ( $h a \beta$ und neit ${ }^{63}$ ) were the motivating forces behind these crimes.

Until this point, the meta-discourse of the play has been the uncovering of the deceitful nature of the Jewish Messiah, and therefore the confirmation of the Christian perspective's righteousness. Considering this, the opening sentences of the confession are of particular relevance. In these lines, the "Messias « character states that the Duke and the prophetess are forcing him with their Christian force ${ }^{64}$ to be totally transparent:

Ir zwinget mich so hart und gnau

Mit eurem cristlichen gewalt,

Das ich nichts heimlichs dahinden behalt ${ }^{65}$

You are forcing me so strongly and precisely

with your Christian force

That I cannot hide anything

59 Emmerson, Antichrist in the Middle Ages, 133 and 215.

60 Der Juden Messias, ed. Przybilski, 1. 343-352, 353-378; Ein spil von dem herzogen von Burgund, ed. von Keller, l. 1. 24-32, p. 179, 1. 1-27, p. 180.

61 See Wenzel, »Do worden die Judden alle geschant«, 246: »ein[en] Kulminationspunkt antijüdischer Agitation«.

62 For details, see Wenzel, »Do worden die Judden alle geschant«, 246-250.

63 Przybilski, Der Juden Messias, 1. 364; Ein spil von dem herzogen von Burgund, ed. von Keller, 1. 13, p. 180.

64 Here, one may think of a confession under torture because of the word gewalt (See, Der Juden Messias, ed. Przybilski, l. 345). The application of torture in order to secure a "true« confession was common in the Germanspeaking territories from the end of the twelfth century (see Schmidt, Einführung in die Geschichte der deutschen Strafrechtspflege, 91 et seq.). Schmidt also mentions that torture was applied in order to force Jewish people to "confess" and subsequently legitimized burning large numbers of them. To assume torture would, however, not coincide with the text's intention.

65 Der Juden Messias, ed. Przybilski, l. 344-346; Ein spil von dem herzogen von Burgund, ed. von Keller, l. 25-27, p. 179. 
In other words, the Christian We hears here through the mouth of the Jewish Other that they have succeeded in skewering the greatest vice of the Antichrist - his deceitful nature. ${ }^{6}$ This means that they feel legitimized to proceed.

\section{Summary of first part analysis}

The analysis of polemics up to this point has delivered the following results: the play as a whole is set up to attack the Jewish characters within its fictitious world, since they are depicted as a threat to the existing hierarchical societal order, which is perceived as a Christian order. In each scene, this threat is factually and proleptically weakened. Thus, in the end, the Christian order is confirmed and the threat of a reversed order in the form of Jewish supremacy is averted. However, at least with the confession of the "Messias " character it has become obvious that the dramatic tension of the play is not built on whether or not the restoration of the Christian side will succeed, but rather on the destruction of the Jewish characters. This destruction is not a straightforward process throughout the play, but it is set up as a self-destruction of the Jewish characters. As a result, the staging creates an atmosphere of rightfulness on the Christian side and an atmosphere of naiveté and blindness in terms of faith on the Jewish side, which connects to the historical discourse that the Jewish people are "blind « in matters of faith since they do not recognize Jesus as the true Messiah, i.e. the one prophesied in the Tanach/Old Testament.

It necessarily follows that the play pursues the othering of the Jewish group from the beginning. The text is unambiguous in depicting the Jewish characters not exclusively as the religious Other, but in characterizing them throughout as the political Other, reaching for supremacy. In two instances, however, the text weakens the process of Othering: first, when the Jewish side stresses that they only want what the Christian side has had for a long time; and secondly, when a Jewish character agrees on the righteousness of the Christian view, thus identifying himself with the Christian side. The text reacts to the first transgression by referring to the false faith of the Jewish side, but it does not react to the second, an omission which is tangible in the absence of such a reaction.

The play is, of course, designed to evoke a whole range of emotions. Hilariousness is evoked first and foremost, and is triggered by common carnival practices. Then throughout, on a semantic and on a performative level as well, the play creates emotions caused by an attitude of Christian superiority on the Christian side which is reflected on the Jewish side through the expression of rather different emotions such as hope, trust, surprise, desperation, horror, rage, envy, hate, and vicarious shame. In particular, vicarious shame is a hybrid since the Jewish side feels ashamed for the action of their "Messias". This emotion is only possible in the first place because the Jewish side views itself, at least for a moment, from the perspective of "Sibilla" - the outside perspective.

As stated earlier, the main purpose of polemics is to create a We - in other words, an in-group, irrespective of whether or not the attack on the enemy in fact works. This pivotal aspect of polemics, mediated in whichever discourse and materiality, may be the most

66 Not surprisingly, Jewish polemical literature circulating in the Early Modern Period within Europe assigns the phenomenon of deceit to the Jesus character; see Przybilski, Zwei Beispiele antichristlicher Polemik, 256. 
precarious to generate. Since the functioning of performative texts also depends on the historical recipient, the issue at stake is whether the recipient follows the direction offered by the text. ${ }^{67}$ Ultimately, the creation of the We becomes unstable when a transgression takes place. Within this part of the play, a transgression that can be picked up by the recipient is induced by the text when the fourth Rabbi expresses vicarious shame for the behavior of the Jewish Messiah character. Since the reproach that is expressed through the emotion of shaming refers exclusively to the Jewish side and is expressed exclusively by the Jewish side, the Christian side is not involved and therefore - for a moment - a historical recipient may escape the directing force of the text.

\section{The verdicts and their executions}

The punishments by the pagans

As announced repeatedly by the megaphone function of the jester and the female jester, the "Jews « have to be punished. After the "Messias« delivers the precondition for the punishment procedure by his self-accusation, the Duke lends his competence to exercise jurisdiction with a courtly gesture to "Sibilla«. However, she rejects the offer with the telling argument that exercising this power does not behoove a woman: Es zim furwaar keinem weibspild nicht. ${ }^{68}$ With this statement, the earlier observation made in the drinking competition scene is confirmed: that "Sibilla - despite all of her powers - does not challenge the gender hierarchy. Clearly, the existing gender hierarchy is instrumentalized to put the Jewish characters down by placing them below women in the societal hierarchy.

Subsequently the Duke, growing impatient, requires his master of ceremony (Hofmeister) to bring the $\operatorname{ding}^{69}$ (thing, i.e. the sentencing) to an end. Thereupon a short interlude follows, emphasizing the alienage of the Heiden (pagans) by letting them speak a $»$ foreign language ${ }^{70}$ only understood by the Hofmeister, who then assumes the role of translator. Accordingly, the Heiden sentence the Jews to the following punishments: (1) extraction of the tongue (die zung zum nack außreyssen, ${ }^{71}$ ); (2) wrapping them in flax and then setting them on fire (mit eim flach $\beta$ vmbwinden / Vnd darnach mit einem licht antzunden ${ }^{72}$ ); (3) hanging them with a stone fixed to their neck and then drowning them (in stein an die hels pinden und henken / darnach all in ein wasser senken, ${ }^{73}$ ); (4) burning them all (Er heißt sie allesamt verprennen, / Kein pessern weck kund er erkennen. ${ }^{74}$ ). Extraction of the tongue was the punishment for

67 Velten, Performativitätsforschung, 552, speaks of »functional performativity«.

68 Der Juden Messias, ed. Przybilski, l. 398; Ein spil von dem herzogen von Burgund, ed. von Keller, 1. 8, p. 181.

69 Der Juden Messias, ed. Przybilski, 1. 399; Ein spil von dem herzogen von Burgund, ed. von Keller 1. 12, p. 181.

70 Der Juden Messias, ed. Przybilski, 1. 404-405 and 1. 412-413, 1. 419-420 and 1. 432-433; Ein spil von dem herzogen von Burgund, ed. von Keller, 1. 16-17 and 1. 25-26, p. 181, 1. 4-5 and 1. 17-18, p. 182. For explanations on the words used, see Przybilski, Kommentar, 165.

71 Der Juden Messias, ed. Przybilski, l. 408; Ein spil von dem herzogen von Burgund, ed. von Keller, 1. 21, p. 181.

72 Der Juden Messias, ed. Przybilski, 1. 414; Ein spil von dem herzogen von Burgund, ed. von Keller, 1. 28-29, p. 181.

73 Der Juden Messias, ed. Przybilski, l. 422-423; Ein spil von dem herzogen von Burgund, ed. von Keller, 1. 7-8, p. 182.

74 Der Juden Messias, ed. Przybilski, 1. 435; Ein spil von dem herzogen von Burgund, ed. von Keller l. 20-21, p. 182.

medieval worlds $•$ No. 7 • 2018 • 114-136 
blasphemy, ${ }^{75}$ burning was generally applied as a punishment for sorcery and heresy ${ }^{76}$ (and was, in particular, applied in the city of Nuremberg during the pogroms of the years 1348/49), ${ }^{77}$ and hanging was the common punishment for theft. ${ }^{78}$

Considering the "judges"' status as disbelievers, the punishments referring to crimes concerning one's correct faith are conspicuous. The text gives the impression that the patterns of force generally applied to pagans are now applied by them to the Jewish characters, again with the effect of putting them on the lowest level of the societal hierarchy, i.e. in this case below the disbelievers. By doing so, the text receives a discourse that is particular to passion plays, where the pagans are depicted as being able to understand the divine nature of Jesus Christ, whereas the Jewish remain »blind« to that epiphany. The text therefore takes an apologetic view, since against that background it is justified that the pagans are ranked higher than the Jewish characters.

This passage contains a layer of subversive criticism when read deconstructively: since jurisdiction is ultimately understood as belonging to one of the pivotal competences of the ruler - which derives from the potestas of God - it appears to be a blasphemous act to pass jurisdiction on to the "Heiden" characters, who have to be understood as being Muslim. ${ }^{79}$ This may be particularly true when considering that the fall of Constantinople in 1453 and various invasions of the south-eastern borders of the Habsburg territories by Ottoman forces took place from 1473 onwards, ${ }^{80}$ and therefore coincided with the time in which the play originated (1486-1493). Moreover, Latin Christendom viewed the Muslin Ottomans as a direct threat to its very existence and this threat was interpreted as a flagellum Dei, as a punishment from God. Thus, the text mocks the Duke by having representatives of the enemy of Christianity in his entourage.

\section{Punishments by the knights}

Subsequently, the Duke's knights (»Des Fursten Ritter«) pronounce their punishments, which are amongst others: (1) that the Jews are to be raped with glowing pans (die Juden allsant arspaß - Mit einer ganz gluenden pfannen ${ }^{81}$ ); (2) that they are stripped of their clothes, fixed beneath a latrine and are shit upon daily (Ganz ploß und nacket ziehe auß, Setz ieden unter ein scheißhaus / Und ließ ein tag aus sie schmaliern/, ${ }^{82}$ ); (3) that they are given neither meat nor drink for eight days, and that they are afterwards directed to a pig's vat in which there is a latrine [...] (Man geb in acht tagen weder trank noch speis, Darnach sie uber ein

75 Schmidt, Einführung in die Geschichte der deutschen Strafrechtspflege, 62.

76 Schmidt, Einführung in die Geschichte der deutschen Strafrechtspflege, 59, 62.

77 Müller, Juden in Nürnberg, 32-33; Schmidt, Einführung in die Geschichte der deutschen Strafrechtspflege, 92.

78 Schmidt, Einführung in die Geschichte der deutschen Strafrechtspflege, 61.

79 See Przybilski, Der Juden Messias, 165. At this point it becomes clear that the text, and therefore also Folz, apply the term "Heiden « according to the excluding definition stated above, i.e. referring to persons neither adhering to the Jewish nor to the Christian faith. In this context and time the term is, therefore, in general used to designate Muslims.

80 Waugh, History of Europe, 323. Housely, Crusading and the Ottoman Threat, 64-65.

81 Der Juden Messias, ed. Przybilski, l. 448-449; Ein spil von dem herzogen von Burgund, ed. von Keller l. 4-5, p. 183.

82 Der Juden Messias, ed. Przybilski, l. 465-467; Ein spil von dem herzogen von Burgund, ed. von Keller, l. 19-24, p. 183. 
seutreck weis, Darein gericht sei ein prifet, $\left.{ }^{83}\right)$; and (4) that their hands and feet are bound together and that they are placed on the road so that everybody passing either by foot or riding may take revenge on them (in alle vire zusamen pinden, / Und setz iglichen an ein straß, / Er kum gefaren zu fuß, zu ros, / Das sich ein ieder rech an in.$^{84}$ ).

Most of these punishments involve the use of feces. If one applies the contemporary concept that the punishment has to mirror the deed, ${ }^{85}$ then the deeds of the "Jews « have to be equated with excrement. This equation is most challenging since excrement is, on the one hand, unavoidable for the human being, but on the other hand it has to be avoided on the level of materiality and also in the discourse. The ability to avoid excrement on both levels is commonly understood to be a sign of civilization and culture. Therefore, the fact that the Jewish characters are faced with these punishments means that their deeds are on the level of feces and consequently so is their culture. In other words they are uncivilized.

Furthermore, these punishments hint, if at all, only very rudimentarily at statutory crimes and their associated customs. More revealing than the punishments themselves, however, is the status of the punisher. This has to be read as a caricature of the chevalier who recovers his and his clan's honor by force, but who in reality has become a mercenary soldier or - worse earned his livelihood through robbery. Here again the text seems to ridicule Maximilian, who hired mercenary soldiers for his military operations, dubbed numerous young men knights, ${ }^{86}$ and stylized himself as a knight during his lifetime. ${ }^{87}$

The institutionalized means of this societal group for recovering its immaterial damage, i.e. its honor, was the feud. This institution was directed towards the humiliation of the enemy, usually by physically attacking his life and/or residence. From its beginning, however, this institution provided for the possibility of waiving such attacks by atonements, i.e. compensation by material goods. ${ }^{88}$ Within the context of this analysis, it may be of interest that in 1449 , a feud was declared against the city of Nuremberg by about 120 parties, a large portion of whom consisted of different ranks of nobility. ${ }^{89}$ It can be assumed that knights were involved as parties in these conflicts, which in one way or another must have been part of the public discourse in the city and therefore known to the author, Folz. Therefore, from this perspective, knights - being the opposite of the city dweller - threatened the city's livelihood when they tried to get financial gain by declaring a feud against the (wealthy) city of Nuremberg. For these reasons, Folz, who identified himself very much with the city, must have viewed "knights " as enemies of the city. This once more displays the text's disdain for the Jewish characters since they are subjected to the ordeal of the city's enemies, but additionally it may be read as expressing disdain towards the societal group of knights, which was still very present at the end of the fifteenth and beginning of the sixteenth century.

83 Der Juden Messias, ed. Przybilski, 1. 473-475; Ein spil von dem herzogen von Burgund, ed. von Keller, l. 30-31, p. 183 and l. 1, p. 184.

84 Der Juden Messias, ed. Przybilski, 1. 484-487; Ein spil von dem herzogen von Burgund, ed. von Keller, 10-13, p. 18.

85 Schmidt, Einführung in die Geschichte der deutschen Strafrechtspflege, 66.

86 Göttert, Ritter, 261, 267.

87 Göttert, Ritter, 259-266.

88 Schmidt, Einführung in die Geschichte der deutschen Strafrechtspflege, 23-24, 48.

89 See Grathoff, Fehde, (no page numbering). 
The last knight judges that the Jewish characters shall all lie beneath a mother pig ("schwein $\beta m u t e r{ }^{90}$ ) and suck its teats, and that the "Messias « character shall lie beneath the tail of the pig, devouring its feces. ${ }^{91}$

\section{The execution of the last verdict by the mob}

By incorporating a Judensau staging, i.e. the depiction of characters marked as "Jews" in close, bodily caressing contact to a sow, the play connects to a contemporary discourse which was materialized as a sculpture on both ecclesiastical and secular buildings, predominantly in the German speaking lands. ${ }^{92}$ In the case of Nuremburg, the Judensau sculpture was and is visible in the east choir of St. Sebald's church..$^{93}$

In this final instance, the Marschalk - with rather threatening rhetoric towards the Duke - requests that jurisdiction is entrusted to the jester and the female jester. ${ }^{94}$ The Duke consents to this proceeding with - again - the remark that they should hurry up..$^{95}$

The jester reacts, however, rather slowly and long-windedly to the Duke's consent:

Ach herr, du pist ein recht narr.

Erlaub mir vnd der nerrin eins [...]

Die weil sie also sawgen hie,

das wir das geltlein von in schwaissen. ${ }^{96}$

Well Duke, you are truly a jester

Permit me

While they are sucking

That we take a little money from them.

This statement, which starts by calling the Duke in an uncomplimentary way "truly a jester «, continues to criticize the Duke by stating that "he and the likes of him " (ir fursten ${ }^{97}$ ) generally promise a lot (kunt wol vil gehaißen ${ }^{98}$ ) but only give very little (Und gebt uns hindennoch ein dreck..$^{99}$ ). On these grounds, the jester suggests that he and the female jester should be given permission to take away whatever valuables the Jewish characters have on them. Accordingly, the female jester commands:

90 Der Juden Messias, ed. Przybilski, 1. 495-499; Ein spil von dem herzogen von Burgund, ed. von Keller, 1. 21-25, p. 184 .

91 Der Juden Messias, ed. Przybilski, l. 495; Ein spil von dem herzogen von Burgund, ed. von Keller, l. 21-25, p. 184.

92 See, for details, Wiedl, Laughing at the Beast. See also Shachar, Judensau, 33-42, on the dissemination of the Judensau motif during the fifteenth century in various German speaking cities, however not specifically discussing the Judensau motif in the east choir of St. Sebald's church in Nuremberg.

93 See Wiedl, Laughing at the Beast, 338 at n. 67, 344.

94 Der Juden Messias, ed. Przybilski, 1. 511-515; Ein spil von dem herzogen von Burgund, ed. von Keller, l. 6-10, p. 185 .

95 Der Juden Messias, ed. Przybilski, l. 517; Ein spil von dem herzogen von Burgund, ed. von Keller 1. 12, p. 185.

96 Der Juden Messias, ed. Przybilski, l. 519-520, 523-524; Ein spil von dem herzogen von Burgund, ed.von Keller, l. 14-15, 18-19, p. 185.

97 Der Juden Messias, ed. Przybilski, 1. 525; Ein spil von dem herzogen von Burgund, ed. von Keller, 1. 20, p. 185.

98 Der Juden Messias, ed. Przybilski, 1. 525; Ein spil von dem herzogen von Burgund, ed. von Keller 1. 20, p. 185.

99 Der Juden Messias, ed. Przybilski, 1. 526; Ein spil von dem herzogen von Burgund, ed. von Keller, 1. 21, p. 185. 
Ir gurt dan die taschen all $a b$ :

Geb yeder herauß, was er drynnen hab ! ${ }^{100}$

You take all your bags off

And hand over whatever is in there.

This passage states in rather plain language what the two jesters aspire to gain from "the chasing away" of the "Jews". Furthermore, it also gives a clue about (at least) the fantasies that were circling in the contemporary discourse of the ordinary people about the expulsion of the Jewish population. The fantasy of the two jesters about robbing the "Jews", however, does have a rather real historical aspect to it which connects to the legal status of the Jewish population: when Maximilian consented to the expulsion of the Nuremberg Jewish population in 1498 , the city eventually had to pay him 8,000 gulden ${ }^{101}$ for the immovable property that belonged to him according to the legal institution which made the Jewish people his servi camerae regis (Knechte der königlichen Kammer) ${ }^{102}$ Vice versa, this means that the movable property of the Jewish people was not bound by the institution of the Kammerknechtschaft. Therefore it seems to have been ravailabler otherwise, i.e. for illegal acquisition by non-Jewish Nuremberg city dwellers.

The fact that the city council issued decrees ${ }^{103}$ fining physical attacks against Jewish persons indicates that there was a well-founded expectation on the side of the city council that the expelled Jewish people would fall prey to robbery by the non-Jewish people of the city. This could be due to mere greed, but was also a way to escape pending debts with their Jewish creditors. ${ }^{104}$

The "execution « of the last verdict makes it blatantly clear that in the fictitious world of the play, the "Jews « were not only equated with the impure in the religious and human realm in order to vilify them in the grossest way possible ${ }^{105}$, but that the final goal was to strip them economically. The text itself delivers two arguments for the legitimization of the Christian side to do so: the first being the confession by the "Messias" in which he admits that the "Jews" have "robbed the Christians" continuously, ${ }^{106}$ thus legitimizing the diachronically present accusation of usury and also the tool of knightly self-help; the second being that »they« - referring to the Duke and the likes of him - do it as well.

100 Der Juden Messias, ed. Przybilski, l 617-618; Ein spil von dem herzogen von Burgund, ed. Von Keller, 1. 20-21, p. 188.

101 Müller, Geschichte der Juden in Nürnberg, 81-85. Toch, Austreibung der Nürnberger Juden, 2-3. 102 Müller, Geschichte der Juden in Nürnberg, 25-26. Toch, Austreibung der Nürnberger Juden, 3.

103 Müller, Geschichte der Juden in Nürnberg, 82. See alsoToch, Austreibung der Nürnberger Juden, 5, who reports armed protection of the expelled Jewish people by city servants when leaving the city.

104 See also Toch, Austreibung der Nürnberger Juden, 5.

105 For a detailed analysis, see Wenzel, »Do worden die Judden alle geschant«, 251-255.

106 Der Juden Messias, ed. Przybilski, 1. 355; Ein spil von dem herzogen von Burgund, ed. von Keller, 1. 4, p. 180: Wie vil groß guts in abgeraubt (»that much wealth we robbed from them«). 


\section{Summary of second part analysis}

The second part of the play has two levels: an overt level which further denigrates the Jewish characters by letting disputable characters, who all belong to the Duke's entourage, judge them; and a subversive level which criticizes and ridicules the Duke. The first group of "judges " are the pagans, understood to be Muslims who - within the historical context of the play - have to be viewed as characters representing Muslim Ottoman Turks. The second group of "judges " are knights of doubtful provenience who reflect the moral doubt towards their sovereign, the Duke, a character in the play who has to be understood as a metaphor or pars pro toto for the then king and later emperor Maximilian I. Whereas the meaning and purpose of the first level is rather obvious and in line with the play's first part, the second level is initially surprising but continuously present, and it results in the weakening of the Duke's moral authority. This observation is particularly confirmed when the jester states upfront that he and his female companion just do what the Duke and the likes of him also do, thus they are copying the attitude of the Duke.

Michael Toch reports that from 1471 onwards, in an attempt to combat the increasing poverty of its craftsmen city dwellers, the city council degraded the legal status of Jewish persons and, in particular, prohibited them from taking interest for money-lending. Within the time frame indicated, the clients of the Jewish money-lenders had indeed changed from previously more powerful clients to being predominantly craftsmen who needed to borrow money in order to secure their livelihood; a situation which was due to early forms of capitalism. ${ }^{107}$ This socio-economic situation may be one layer, amongst others, against which to read the actions of the jester characters.

\section{Résumé}

As stated by Dorschel, ${ }^{108}$ the ultimate goal of polemics is tto create a $>$ we $[$ [...] that excludes the group against whom the polemical attack is directed " from participating in some social fabric. Does the text succeed in doing so? The analysis demonstrates that the text manages throughout to evoke heavy negative emotions, which make an argument for an irreconcilable divide between the Jewish and the Christian side, evoking within the latter the emotion of permanent superiority based on the idea that they are the bearers of the "true « religion. ${ }^{109}$ It is proven that this divide is a construct when the text applies the technique of self-flagellation to the Jewish side, since this attitude performs the aggression of the We against the Other as the latter's own aggression, leading to their well-deserved self-destruction. The effect thereof is that any moral hurdle whatsoever on the Christian side is avoided. Only this technique allows the ultimate emotion of schadenfreude ${ }^{110}$ to be raised, which ultimately leads the staged Christian side to become violent and any historical audience to experience expulsion as a spectacle. How does the text connect to historical facts? It could be shown that the text received contemporary history regarding the city of Nuremberg, its ongoing efforts to expel its Jewish residents, and the interactions with its then relevant ruler, Maximilian.

107 Toch, Austreibung der Nürnberger Juden, 6-9.

108 Dorschel, Passions of the Intellect, 683.

109 With respect to the construction of superiority and hegemonical claims in polemical literature of Jewish provenience, see Pryzibilski, Zwei Beispiele antichristlicher Polemik, 260.

110 See also Dorschel, Passions of the Intellect, 684. 
This historical framework, however, does not explain the play's attacks leading to the dehumanization of the Jewish characters. A decisive observation is that although other work by Folz contains anti-Jewish polemics as well, the Fastnachtspiel Der Juden Messias is by far the crudest, since the polemics show what concrete actions have to be taken in order to expel the Jewish characters. These actions require the construction of a We in the way stated above by Dorschel. In other words, at a certain point the polemics in the play become agitation in the sense that they are staged to invoke concrete actions by historical recipients. An explanation for Folz's excess in this play may be his contacts with members of the Nuremberg elite ${ }^{111}$ who, at the time of the play's origin, were very much in favour of an expulsion of the Jewish residents. This conveniently coincided with Folz's own ambitions as a social climber within the societal hierarchy of Nuremberg.

Are these findings tempered by the genre of the play? The text announces itself as a play to be performed during the carnival season for entertainment purposes. This announcement, together with the play's revue structure and its brute and vicious language that stresses the obscene, are clear features of the carnival play. The play is distinguished from the genre of the Fastnachtspiel by its length, its rather large number of characters, its depiction of a self-contained story despite its revue setting, and, above all, by its total focus on the denigration of the Jewish characters. The latter feature is traditionally present in the religious play, and specifically in the passion plays of the fifteenth and sixteenth centuries from the German speaking lands. Additionally, the play at hand introduces further motives that are typical for the passion play, for example the extensive elaboration on the blindness of the Jewish characters in matters of faith, as well as the motive of gluttony and, by extension, usury. These observations coincide with the declared motivation of its author, Folz, to elevate the Fastnachtspiel to the level of the religious play. ${ }^{112}$

The play is divided in a recognizable manner, with two major parts. It could finish with the confession of the character "Messias", representing the Jewish false Messiah, which is the final scene in the first part. But instead the play reaches its overall peak in its second part, in the Judensau scene. This staging and the intensity of the Judensau scene on an emotional and imagined physical level are a vital reminiscence of the crucifixion scene in the passion play. Both scenes are the climax of an irreversible development, and both cater to violently colored thrill and sensation, and, therefore, in essence trigger identical emotions. Any passion play, however, is driven by the intention to idealize the emotions of the Christian side in order to elevate them; Der Juden Messias is driven by the intention to dehumanize the emotions of the Jewish side in order to trigger the Christian side's nefariousness but, as a reflex, also to justify this emotion on the Christian side. This latter observation moves Der Juden Messias closer to the genre of the passion play than to that of the Fastnachtspiel.

111 Janota, Folz, 780. See also Przybilski, Kommentar, 163.

112 Janota, Folz, 779-780. Wenzel, »Do worden die Judden alle geschant«, 197. 
How is the second part of the play to be positioned? As the analyses demonstrated, the text criticizes the Duke - in this context understood as a metaphor for Maximilian and his politics - throughout the second part of the play, which is a form of "Hoheitskritik « ${ }^{113}$ This subversive carnevalesque layer of the text becomes overt when the male jester openly requests from the Duke permission to do "what he and the likes of him « do. In this instance the jester fulfills his true function, i.e. to mirror the world, thereby mocking the Duke as being a jester himself. Mocking somebody serves to denigrate the person; its opposite is to praise somebody in earnest, which the jester never does. Rather, precisely by mocking, he connects to the Duke, thereby establishing a We with him. Of course this We sheds light on the moral standing of the Duke.

The Roman-German reigning king, Maximilian, did not consent immediately to the request from Nuremberg city council to expel the Jewish population. ${ }^{114}$ Nevertheless, it is an open question whether or not the city council was pleased by a Fastnachtspiel containing such a rough and obscene criticism of the ruler, not only with respect to his reluctance towards an expulsion of the Jewish population but also with respect to the doubtful composition of his entourage which crystallized in the second part of the analysis. One may, however, assume that any historical recipient, including Maximilian himself, recognized the subversive layer, an aspect that may suggest that the play was too sensitive to be performed on the historical occasion of the ruler's visit to Nuremberg regardless of carnival traditions. This assumption is supported by the Spruch Folz wrote in the year of Maximilian's visit cited above, which mentions the live performance of a Fastnachtspiel in order to entertain the ruler and the people but not the performance of his Fastnachtspiel. ${ }^{115}$

113 Biehl, Zur Narrenfigur im `Salomon und Markolf^, 23, at n. 108.

114 Müller, Juden in Nürnberg, 81.

115 According to a poem (Spruch) written by Folz on the occasion of Maximilian's stay in Nuremberg in 1491, a Fastnachtspiel was performed. The conclusion is therefore that it was not his. 


\section{References}

\section{Manuscripts}

Von dem Hertzog von Burgundy von der juden messias vnd wie jn Sibilla vertrib kurtzweylig zuo hören, Wolfenbüttel, Herzog August Bibliothek, Cod. Guelf. 18.12. Aug. 4.

Ein vasnachtsspil, die alt und neu ee, die sinagog, von uberwindung der Juden in ir Talmut etc., Wolfenbüttel, Herzog August Bibliothek, Cod. Guelf. 18.12. Aug. 4.

Der Juden und Christen streit vor kaiser Constantinus, ein fasnachtspil. München, Bayerische Staatsbibliothek, Cgm 439.

\section{Primary and secondary literature}

Ben-Sasson, Haim Hillel, The Middle Ages, in: Haim Hillel Ben-Sasson (ed.), A History of the Jewish People (revised edition), (London 1977) 574-592.

Biehl, Theresia, Zur Narrenfigur im sSalomon und Markolf bilski (ed.), Studien zu ausgewählten Fastnachtspielen des Hans Folz (Wiesbaden, 2011) 1-36.

Der Juden Messias, ed. Martin Przybilski, in: Klaus Ridder and Hans-Hugo Steinhoff (eds.), Frühe Nürnberger Fastnachtspiele (Paderborn, 1998).

Deutsches Wörterbuch von Jacob und Wilhelm Grimm, University of Trier, (Trier Center for Digital Humanities 2011): kompetenzzentrum.uni-trier.de/de/projekte/der-digitalegrimm.

Dorschel, Andreas, Passions of the Intellect: A Study of Polemics, Philosophy 90 (2015) 679684.

Ein spil von dem herzogen von Burgund, ed. Adalbert von Keller, in: Adalbert von Keller (ed.), Fastnachtsspiele aus dem 15. Jahrhundert, Vol. 1 (Stuttgart 1853-1858) 169-190.

Ein vasnachtsspil, die alt und neu ee, die sinagog, von uberwindung der juden ir talmut etc., ed. Adalbert von Keller, in: Adalbert von Keller (ed.), Fastnachtsspiele aus dem 15. Jahrhundert, Vol. 1 (Stuttgart 1853-1858) 1-33.

Emmerson, Richard Kenneth, Antichrist in the Middle Ages (Manchester, 1981).

Fischer-Lichte, Erika, Performativität (revised edition), (Bielefeld, 2016).

Glier, Ingeborg, Rosenplüt, Hans, in: Kurt Ruh, Gundolf Keil, Werner Schröder, Burghart Wachinger and Franz Josef Worstbrock (eds.), Verfasserlexikon der deutschen Literatur des Mittelalters, Vol. 8 (Berlin, 1992) 195-211.

Göttert, Karl-Heinz, Die Ritter (Stuttgart, 2011).

Grathoff, Stefan, Fehde, in: Glossar historischer Fachbegriffe, digitale Bibliothek des Instituts für Geschichtliche Landeskunde an der Universität Mainz e. V., Regionalgeschichte, (Mainz 2017).

Hans Folz, Die Reimpaarsprüche, ed. Hanns Fischer (München, 1961).

Jacob Grimm. Deutsche Mythodologie [sic], ed. Elard Hugo Meyer, Vol. 3 (Berlin, 1878).

Housley, Norman, Crusading and the Ottoman Threat 1453-1505 (Oxford, 2013).

Janota, Johannes (ed.), Die Frankfurter Dirigierrolle, in: Hessische Passionsspielgruppe, Vol. 1 (Tübingen, 1997).

Janota, Johannes, Folz, Hans, in, Kurt Ruh, Gundolf Keil, Werner Schröder, Burghart Waichinger and Franz Josef Worstbrock (eds.), Verfasserlexikon der deutschen Literatur des Mittelalters Vol. 2 (Berlin, 1980) 769-793.

Kaiser Constantinus, ed. Adalbert von Keller, in: Adalbert von Keller (ed.), Fastnachtsspiele aus dem 15. Jahrhundert, Vol. 1 (Stuttgart 1853-1858) 796-819.

Könneker, Barbara, Hans Sachs (Stuttgart, 1971).

Ludus de Antichristo. Das Spiel vom Antichrist, trans. Rolf Engelsing (Stuttgart, 1968). 
Mittlmeier, Christine, Publizistik im Dienste antijüdischer Polemik (Frankfurt/Main, 2000).

Müller, Arnd, Geschichte der Juden in Nürnberg 1146-1945 (Nürnberg, 1968).

Nöcker, Rebecca, vil krummer urtail. Zur Darstellung von Juristen im frühen Nürnberger Fastnachtsspiel, in: Klaus Ridder (ed.), Weltliches Schauspiel in literarischen und kulturellen Kontexten (Tübingen, 2009) 239-284.

Opelt, Ilona, Die Polemik in der christlichen lateinischen Literatur von Tertullian bis Augustin (Heidelberg, 1980).

Nottarp, Hermann, Gottesurteilstudien (München, 1956).

Przybilski, Martin, Zwei Beispiele antichristlicher Polemik in Spätantike und Mittelalter, in: Eveline Brugger and, Birgit Wiedl (eds.), Ein Thema - zwei Perspektiven. Juden und Christen im Mittelalter und Frühneuzeit (Innsbruck, 2007) 253-268.

Przybilski, Martin, Anhang, in: Klaus Ridder and, Hans-Hugo Steinhoff (eds.), Frühe Nürnberger Fastnachtspiele (Paderborn, 1998) 171-202.

Przybilski, Martin, Kommentar, in: Klaus Ridder and, Hans-Hugo Steinhoff (eds.), Frühe Nürnberger Fastnachtspiele (Paderborn, 1998) 111-167.

Rommel, Florian, Judenfeindliche Vorstellungen im Passionsspiel des Mittelalters, in: Ursula Schulze (ed.), Juden in der deutschen Literatur des Mittelalters (Tübingen, 2002) 183-208.

Seebold, Elmar, Kluge Etymologisches Wörterbuch der deutschen Sprache (revised edition) (Berlin, 2002).

Shachar, Isaiah, The Judensau. A Medieval anti-Jewish Motif and its History (London 1974).

Schmidt, Eberhard, Einführung in die Geschichte der deutschen Strafrechtspflege (revised edition), (Göttingen, 1965).

Stauffer, Hermann, Polemik, in: Gert Ueding (ed.), Historisches Wörterbuch der Rhetorik (Tübingen, 2003).

Toch, Michael, »UMB GEMEYNS NUTY UND NOTTDURFFT WILLEN«: Obrigkeitliches und jurisdiktionelles Denken bei der Austreibung der Nürnberger Juden 1498/99, in: Michael Toch (ed.), Peasants and Jews in Medieval Germany: Studies in Cultural, Social, and Economic History (Aldershot, Hampshire, 2003) 1-21.

Velten, Hans Rudolf, Performativitätsforschung, in: Jost Schneider (ed.), Methodengeschichte der Germanistik (Berlin, 2009) 549-571.

Waugh, William Templeton, A History of Europe from 1378 to 1494 (New York, 2016).

Wenzel, Edith, "Do worden die Judden alle geschant". Rolle und Funktion der Juden in spätmittelalterlichen Spielen (München, 1992).

Wiedl, Birgit, Laughing at the Beast: The Judensau. Anti-Jewish Propaganda and Humor from the Middle Ages to the Early Modern Period, in: Albrecht Classen (ed.), Laughter in the Middle Ages and Early Modern Times: Epistemology of a Fundamental Human Behavior, its Meaning, and Consequences (Berlin, 2010) 325-364.

Wuttke, Dieter, Nachwort, in: Dieter Wuttke (ed.), Fastnachtspiele des 15. und 16. Jahrhunderts (revised edition), (Stuttgart, 2006) 401-419. 


\title{
The Text as Heretic: Mixed Genres and Polemical Techniques in a Refutation of the Mirror of Simple Souls
}

\author{
Justine L. Trombley*
}

This article examines the style and rhetoric of a fourteenth-century treatise written against the condemned mystical work The Mirror of Simple Souls. The treatise addresses thirty-five extracts from the Mirror which are refuted as errors. Rather than merely a list of erroneous propositions, the text is a polemical narrative which employs various genres and literary styles from the canon of anti-heretical writings. The article notes how these various genres are combined to produce a comprehensive condemnation of the Mirror, and examines the rhetoric used to address it. The text is shown to go beyond merely refuting the Mirror's doctrine. It also personifies the text by connecting it to the broader concept of heresy through the use of standard tropes that are usually used to describe the person of the generalised "heretic". This makes it unique in the history of the Mirror's reception, and shows how an anonymous text was assessed and characterised with tactics more often applied to human agents, rather than texts.

Keywords: polemic; anti-heretical texts; Marguerite Porete; The Mirror of Simple Souls; heresy; condemned texts; textual refutation

The Mirror of Simple Souls (Speculum simplicium animarum) is a mystical treatise written as a dialogue between Love, the Soul, and Reason. Originally composed in Old French, the Mirror discusses the Soul's journey to union with the divine. On this journey, the Soul attempts to free itself from both worldly practices - which includes institutional practices such as fasting, sermons, and prayers - and also from its own will, desires, and identity. Through Love's guidance, the Soul is eventually led to the state of "annihilation", in which it dissolves into indistinct union with God. ${ }^{1}$ As is now well known, the Mirror attracted its share of controversy. It was condemned as heretical twice in the early fourteenth century, once in Valenciennes and again a few years later in Paris. Its author, Marguerite Porete, was also condemned and burned at the stake in Paris on 1 June $1310 .^{2}$ Nevertheless, the Mirror survived destruction and circulated anonymously across late medieval Europe in four languages:

* Correspondence details: Email: jltrombl@gmail.com.

I am grateful to the reviewers and to Sita Steckel for their very helpful comments and criticisms.

1 For the Middle French and Latin texts, see Porete, Mirouer des Simples/Speculum, ed. Guarnieri and Verdeyen. For the modern English see Porete, Mirror of Simple Souls, trans. Babinsky, and Porete, Mirror of Simple Souls, trans. Colledge et al.

2 For a full account of Marguerite's trial see Field, Beguine, the Angel, and the Inquisitor. 
Latin, Italian, Middle English, and French. In apparent contrast to its fate in Valenciennes and Paris, numerous readers accepted it as beneficial spiritual reading in the late fourteenth and early fifteenth centuries. ${ }^{3}$ But this positive reception did not represent a total triumph of the Mirror over its critics. Its Latin version in particular continued to attract suspicion and opposition. ${ }^{4}$ The Latin, now thought to have been possibly produced in Southern France between the years 1300-1317 - fairly early in the Mirror's circulation - had the broadest geographical circulation of the Mirror's linguistic traditions. ${ }^{5}$ It had a particularly robust circulation in Italy, and it is there where new suspicions and condemnations of the Mirror appeared in the fifteenth century. Between the years 1417-1439, the Mirror was denounced in sermons, banned from certain monastic congregations, confiscated from citizens, and caught up in an inquisition. ${ }^{6}$

While this contentious history shows how the Mirror could sharply divide opinion, it has not so far produced evidence that readily marks it for inclusion in a special issue on polemics. ${ }^{7}$ While a single, clear definition of polemic is difficult to give, on a general level it can be defined as discourse which involves controversy and confrontation. ${ }^{8}$ More specifically, it can be an exchange in which an attacker asserts the "truth " of their position against that of an opponent using hostile language, often in the form of a debate. ${ }^{9}$ Texts written to combat heresy frequently took this latter form. The classic examples of anti-heretical polemics are those texts written against Cathars and Waldensians in the thirteenth century, where an "orthodox" attacker took on the "heretical " enemy in order to disprove error. ${ }^{10}$ In these quasi-dialogic texts, the error of the heretic was the springboard from which the polemicist launched a counterargument that would both refute error and present the truth of Church doctrine. As part of the process, the author constructed a »living " opponent, the rhetorical heretic expounding his error. ${ }^{11}$

3 For an overview of the Mirror's various linguistic circulations see the essays in Stauffer and Terry (eds.), Companion to Marguerite Porete, 155-292.

4 Trombley, Mirror Broken Anew.

5 On the Latin's early origins see Trombley, New Evidence, 147-150, and Piron, Marguerite, 86-88. On the manuscripts of the Latin tradition and their distribution see Trombley, Latin Manuscripts, 186-217 and also Trombley, New Frontiers.

6 For an overview of these denunciations see Guarnieri, Movimento del Libero Spirito, 466-476; Sargent, Medieval and Modern Readership, 93-96; Trombley, Latin Manuscripts, 206-217.

7 This article was first presented as a paper at the 2015 Leeds International Medieval Congress as part of the thematic strand »Religious Polemics Compared".

8 Hettema and Van der Kooij, Introduction, xiii

9 Southcombe et al., Introduction, 6. For more on types and forms of religious polemics, see Dascal, On the Uses of Argumentative Reason, 3-20.

10 On this genre, see Sackville, Heresy and Heretics, 13-40.

11 Sackville, Heresy and Heretics, 37. As Dascal points out, these texts were a type of "staged polemic «, in which the audience (the reader) is only a witness and not a participant. The author decides how to present his opponent's stance and works for the achievement of his own goals. Dascal, On the Uses of Argumentative Reason, 8. 
Although there was plenty of hostility shown to the Mirror, most of the efforts directed against it do not fit into this kind of anti-heretical polemic. In the records of Marguerite's trial and execution three of the Mirror's errors are mentioned and presented as proof of its heresy, but are not engaged with or refuted at any length. ${ }^{12}$ Similarly, the denunciations in Northern Italy are short references, not constituting any lengthy discourse. A slightly more sustained refutation can be found in a fifteenth-century manuscript, on folios 26r-32r of Vatican, Biblioteca apostolica vaticana, MS Vat. lat. 4953. Here there is a list of the Mirror's errors which are followed by short refutations. ${ }^{13}$ There are at least thirty points taken from a Latin translation of the Mirror which are systematically refuted in an almost bullet-point like style, where citations are merely lined up one after the other as counter-proofs to the Mirror's own assertions. Yet while the Vatican text demonstrates opposition to and doctrinal concern over the Mirror, it is not a polemic; it belongs more to the genre of error lists, a common way of condemning texts which often took place in academic heresy investigations and condemnations. ${ }^{14}$ The text and only the text is addressed, and it offers a succinct demonstration of error with little elaboration. While this, like many anti-heretical polemics, was concerned with addressing specific theological errors, it does not take on the dialogic, debate-like style which engaged with an opponent, nor does it employ much hostile language or imagery. No such extended discourse has previously been found in connection with the Mirror, either in its first two condemnations at Valenciennes and Paris, or in its later circulations.

But a recently re-discovered text, found on folios 215v-221v of Padua, Biblioteca universitaria, MS 1647, changes this. This codex, owned by the fifteenth-century Paduan professor of canon law Giacomo de Zocchi, is a legal compilation, containing also a Decretals commentary, decisions from the Roman Rota, and a text from the Council of Constance..$^{15}$ The text in question appears on the last seven folios of the codex. Although watermark evidence shows it was copied in the early fifteenth century in Bologna, internal textual evidence suggests that its original composition likely took place sometime before $1317 .{ }^{16}$ This means that it was composed very near to Marguerite's trial and execution, or possibly even before this event. ${ }^{17}$ At first glance, the text appears to be of the same character as the Vatican list: it presents thirty-five extracts from a Latin Mirror of Simple Souls and refutes each one in turn using mostly canon-legal and scriptural citations. Its original author is, for now, unknown, but its heavy reliance on canon law implies that it was written by a canon lawyer, one who had no knowledge of the Mirror's origins and authorship. ${ }^{18}$ Whether he composed this text on commission or on his own initiative is uncertain, but the tone of the piece suggests he took the

12 For the trial documents see Verdeyen, Procès d'inquisition, 47-94. For the English translations see Field, Beguine, the Angel, and the Inquisitor, 209-231.

13 This list was edited and published in Guarnieri, Movimento del Libero Spirito, 649-660. This list possibly originated from a consultation on the Mirror that was solicited from theologians at the University of Padua in 1437. See Guarnieri, Movimento del Libero Spirito, 474-475, and Trombley, Latin Manuscripts, 195-197.

14 See Koch, Philosophische und theologische Irrtumslisten, 423-450; Courtenay, Inquiry and Inquisition, 168-181; and Thijssen, Censure and Heresy.

15 Trombley, New Evidence, 140. On Giacomo de Zocchi see Griguolo, Per la biografia.

16 At the moment, it is not certain where its original composition took place. For a more detailed description of this manuscript and the evidence establishing the text's early date of origin see Trombley, New Evidence, 137-152. I am currently working on both an edition of this text and an in-depth study of it as part of a monograph.

17 Trombley, New Evidence, 149-150.

18 Trombley, New Evidence, 146. 
task on himself. ${ }^{19}$ Its pre-1317 date of composition means that its refutations of the Mirror were constructed without reference to the Clementine decree Ad nostrum. This decree, which was promulgated with the rest of the Clementines in 1317, became the standard text used to identify and refute sfree spirit $<$ heretics in the fourteenth and fifteenth centuries. ${ }^{20}$ It was also the standard text used to criticise the Mirror in the fifteenth century. ${ }^{21}$ The author of this Paduan text does, however, see in the Mirror the same issues which Ad nostrum would address, namely: indifference to moral guidance and practice of the virtues; the rejection of Church practices such as fasting, prayers, sermons, etc.; the self-acquisition of divine knowledge without dependence on scripture or other authorities; and the ability of the human Soul to achieve a state of divinity. ${ }^{22}$ Therefore, this text offers an intriguing glimpse into how a Mirror critic constructed his arguments against it before a "pre-packaged « condemnation like Ad nostrum was available for reference.

While the Vatican error list also shows concern over these same issues, when examined more closely the Paduan text in fact differs significantly from that of the Vatican. It has a narrative style, more like a treatise than a list. The citations are not laid out in a list-like format, but are rather part of a larger explanatory discourse that has a distinct, individual authorial voice. Upon further scrutiny, it becomes clear that the author engages with the Mirror on both a doctrinal and a rhetorical level in the manner of a polemic. It most closely resembles the anti-heretical polemics of the thirteenth century, in that it takes the form of a statement-and-response which presents heretical error in order to refute it and reaffirm orthodox interpretation. But rather than fitting into any single genre or making use of any one technique, it instead seems to meld several different ones together. The result is a work which draws upon multiple existing formats and rhetorics to make a single polemic against both the Mirror as a text, and the Mirror as a heretical person. This article will explore the construction of the Paduan text, examining how it mixes genres, how it addresses the Mirror on a rhetorical level, and how the author constructs and characterises an anonymous, disembodied text in a way that presents it as a dynamic - and dangerous - opponent.

As noted above, the author was in all likelihood a canon lawyer; the majority of quotations and citations which he uses - aside from his scriptural ones - are canon-legal, and not theological. His approach to the text is extremely literal. He seems to have little tolerance for the metaphorical and paradoxical language of mysticism, and takes the Mirror's statements at face value. ${ }^{23} \mathrm{He}$ begins the text by copying out the first error from the Mirror, taken from chapter $5 \cdot{ }^{24}$ But, rather than immediately refute the error, he initially sets it aside and instead begins with what is essentially a short legal consilium on the question of the text's overall

20 On Ad nostrum's use see Lerner, Heresy of the Free Spirit; Kieckhefer, Repression of Heresy, 21-32; and Lerner, Meister Eckhart's Specter, 115-134. The Latin and English of Ad nostrum can be found in Makowksi, When is a Beguine not a Beguine?, 93-95.

21 See Trombley, New Evidence, 147-148. The Vatican error list does make use of Ad nostrum in its refutations. See Guarnieri, Movimento del Libero Spirito, 649-660.

22 Trombley, New Evidence, 142-143.

23 Trombley, New Evidence, 145.

24 Mirouer des Simples/Speculum, 19-21. The chapter division is that used by Guarnieri and Verdeyen. 
legitimacy. He begins with a question: "It seems the position which ought to be questioned concerning this little work is whether it should be received (recipiendum) by the Church. $\aleph^{25}$ This forms the central question that drives his argument. From there, he proceeds to answer it point by point, using primarily legal citations, to show why the book cannot be accepted as good spiritual reading, showing clear similarities to the consilium format. ${ }^{26} \mathrm{He}$ lays out three main points, each one supported with various citations from Gratian's Decretum, the Liber Extra, the Liber Sextus, and the occasional scriptural quotation. The three points, connected by the theme of legitimacy, build upon one another. First, it cannot be received because it is apocryphal, that is, its origins and authorship are entirely unknown. ${ }^{27}$ This point on authority then blends into the second, more serious charge: it cannot be accepted because it is new doctrine entirely taken from the author's own head and none of its arguments are supported by scripture or the doctors of the Church. This connects it to the essential legal definition of a heretic found in Gratian. ${ }^{28}$ Thirdly and finally, not only does the Mirror produce new doctrine, but it is disseminating this doctrine with no mandate from the Church, and therefore usurps authority from the Church. ${ }^{29}$ These arguments establish a judgment on the text's overall legitimacy before the author even addresses the text directly. This provides a legal underpinning to the detailed refutations which follow, marking the text out as unacceptable from the beginning.

When he does turn to the Mirror's specific contents at the end of his short consilium - "Now we come to the text of this little work" - he shifts to a different technique for the main body of his treatise. ${ }^{30}$ Having established a baseline of illegitimacy for the text on legal grounds, he moves from addressing the question of the book as a whole to attacking and refuting the specific errors found within it. Here he takes up a polemical format, a scholastic statement-and-response familiar from the anti-heretical polemics of the thirteenth century. In those texts, the author summarises the heretical position and then uses it as a launch point for his refutation. In the anti-Mirror text, direct quotations from the Mirror itself serve this purpose. ${ }^{31}$ While a few extracts here and there are paraphrased, the text is largely reproduced

25 MS 1647, fol. 215v: De hoc opusculo positio quaerendum videtur an sit ab ecclesie recipiendum. "Received« or perhaps also "accepted « in this case seems to mean whether it can be accepted as true or authoritative and appropriate religious reading. This usage of recipere in relation to texts is probably echoing the language of Gratian's $15^{\text {th }}$ distinction, dealing with approved and unapproved texts, given that this is discussed in the text immediately following. See Gratian, Decretum Magistri, D. 15 c. 3, ed. Friedberg, 36-40.

26 See for comparison the consilia in Parmeggiani, I consilia procedurali, 1-215.

27 MS 1647, fol. 215v. Here the author cites Gratian's 15th distinction (D. 15 c. 3), where several apocryphal works are listed and described as texts that "Catholics should avoid« (a catholicis vitanda sunt). Gratian, Decretum Magistri, ed. Friedberg, 36-40. While mapocryphal« did not automatically mean heretical, it did cast doubt or suspicion on the text's truth and authority. For a discussion of medieval definitions of "apocryphal« see Dzon, Cecily Neville and the Apocryphal Infantia salvatoris, 267-271.

28 MS 1647, fol. 215v. The canons cited are C. 24 q. 3 c. 27 and 28. Gratian, Decretum Magistri, ed. Friedberg, 997-998

29 MS 1647, fol. 215v.

30 MS 1647, fol. 215v. Nunc ad textum huius opusculi veniamus. The use of the diminutive »opusculum « could possibly indicate that this author had a shorter version of the Mirror in front of him - and there is some textual evidence to suggest this, see Trombley, New Evidence, 142, n. 23 - but it could also merely have been a physically small codex, as in the cases of the Mirror copies found in Vatican, Biblioteca apostolica vaticana, MSs Vat. lat. 4355, Chigianus B IV 41, Rossianus 4, and Chigianus C IV 85, none of which are over $215 \mathrm{~mm}$ in length.

31 In its fifteenth-century copy, the Mirror quotations are clearly distinguished from the rest of the text by being written in a larger, neater hand separated by a space above and below. 
verbatim from a Latin Mirror copy, as the text more or less matches the readings in other Latin Mirror manuscripts, and other direct quotations are occasionally used in the midst of a refutation to provide clarification or further support to the argument. ${ }^{32}$ This indicates that he was working from an actual copy of the Mirror, rather than merely a set list of extracts. ${ }^{33}$

Anti-heretical polemics often had two purposes: the main purpose of attacking error, and the embedded purpose of demonstrating orthodox truth. ${ }^{34}$ In a text such as Moneta of Cremona's Summa adversus catharos et valdenses or Alain of Lille's De fide catholica, various heretical positions are explained, and then are shown to be false with counterarguments supported by scriptural and theological citations; these counterarguments simultaneously provide "correct « interpretation and doctrine. ${ }^{35}$ This is clearly the case in the Paduan text. The latter aim, the demonstration of truth, is made explicit before the treatise itself even begins. Written above the text at the top of the work's first folio, folio $215 \mathrm{v}$, is a quotation from 1 Corinthians 11:19, one common to discourse on heresy: »For there must also be heresies, so that those who are approved may be made manifest $« .{ }^{36}$ In the main body of the text after his opening legal assessment, the author takes precisely this route. His refutations, supported by canon-legal, biblical, and occasional theological citations, both prove the error of the Mirror and edify the reader as to correct doctrine. A good example can be found in his response to the fifth error, which comes from Chapter 8 of the Mirror, in which it states that the Simple Soul still possesses the Virtues, but is free from service to them, and that the Virtues instead now serve the Simple Soul. ${ }^{37}$ The author of the polemic dismisses this construction as the Soul trying to have it both ways. One either lives temperately or intemperately, he states, and there is no middle ground between vice and virtue, citing as proof Gratian's 32nd Causa. ${ }^{38} \mathrm{He}$ then notes that if the Simple Souls do not have the practice of the Virtues, then they are outside the status of salvation, and if outside the status of salvation, they are outside of God's love, because:

32 Further discussion of the relationship between the Paduan Mirror extracts and the text of other Latin Mirrors can be found in Trombley, New Evidence, 141-142.

33 Trombley, New Evidence, 142. This is also indicated by the author's remark near the beginning of his treatise that if one makes an inspection "from the beginning of this little work all the way up to the end " (a primo huius opusculi usque in finem) it becomes clear its author made everything up from his own head. MS 1647, 215v.

34 See Sackville, Heresy and Heretics, 41.

35 For excerpts of these texts see Wakefield and Evans, Heresies of the High Middle Ages, 214-220 and 301-329.

36 MS 1647, fol. 215v.: Oportet et hereses esse, ut qui probati sunt manifesti fiat. On this passage see Grundmann, »Opportet et haereses esse«. Forthcoming in an English translation in Grundmann, Essays on Heresy.

37 MS 1647, fol. 216v; found in Mirouer des Simples/Speculum, 29.

38 MS 1647, fol. 216v. The specific citation is C. 32 q. 1 c. 9. See Gratian, Decretum Magistri, ed. Friedberg, 1117. 
'Wisdom will not enter into a malicious soul, nor dwell in a body subject to sins [Wisdom 1:4]. Additionally, there are two forces in the Soul: One is higher, that is reason, through which God wishes man to comprehend the might of the works of God and his name, and to praise and glorify his works, [as in] Ecclesiasticus 17[:7-8]. He wished that the lower part, which is sensuality, to be subservient to reason, which is the higher part, but not the reverse...Again, there are two [things] necessary to salvation, namely to recede from evil and to do good, whence the prophet asks in Psalms 33[:13]: 'Who is the man who desires life? Who chooses to see the good days? «, and below, responding: 'Decline from evil and do good<, etc. [Psalms 36:27]. Thus it is not possible to do good except by behaving virtuously. ${ }^{39}$

The instructive purpose here is clear, and it achieves both aims. The claim of the Simple Soul is shown to be wrong with canon law and scriptural evidence, and such evidence "manifests « the truth: that the Virtues are necessary to living a good life and to achieving salvation. This is the prevailing format for the rest of the treatise, and by the end the Mirror has been shown to be "false, deceitful, and heretical«, and several "truths" have been reinforced: the necessity of obedience to the Church, the inability of man to achieve divine status in the present life, the importance of the sacraments to achieving salvation, and many others. Therefore we see the author of this text pivoting from a purely legal demonstration of the book's illegitimacy to a demonstration of the book's doctrinal illegitimacy through refutation of its contents, in the manner of a scholarly polemic.

This latter technique, of course, is not remarkable in and of itself, either within an antiheretical context or in broader medieval intellectual debates. But the author brings in other elements which make intriguing modifications to it. In addition to adding the legal judgment at the beginning, the author also engages in a construction of the Mirror not just as a text, but as an opponent. Embedded in his doctrinal refutations are also attacks on the Mirror's character, and he uses rhetoric usually used against a person or group. The Mirror is not addressed merely as an object or a vehicle for scholarly refutation and discourse, but is also animated to serve as a rhetorical opponent. This characterisation does not necessarily maintain the distinct images of "author" and "text«, but presents something more ambiguous.

At the beginning of the text, in his consilium-esque introduction, the author does initially address the Mirror in strictly text-and-author terms. He immediately notes that the work is apocryphal, because its origins and its author are completely unknown, and although it may contain some truths, it nevertheless contains many falsehoods, and therefore cannot be accepted. He directs the reader to the legislation on apocryphal books and unaccepted texts found in Gratian's fifteenth distinction, a copy of the sixth-century Gelasian decree..$^{40}$ The Mirror's authorial anonymity weakens the text's legitimacy; what is more, he declares that

39 MS 1647, fol. 216v.: "In malivolam animam non introibit sapientia, nec habitabit in corpore subdito peccatis". Preterea due sunt vires anime: una superior, que est ratio, per quam voluit deus hominem cognoscere magnalia operum dei et nomen eius, et opera laudare et glorificare, Eccleisiastici xvii. Voluit quod inferiorem partem, que est sensualitas, subservire rationis, que est superior pars, non autem econtra.... Item duo sunt necessaria ad salutem, scilicet recedere a malo et facere bonum unde propheta quaerens psalmi xxxiii: "Quis est homo qui vult vitam diligit dies videre bonos?" et subdit respondendo "recedere a malo et fac bonum ", etc. Constat autem non posse fieri bonum nisi virtuose agendo.

40 Gratian, Decretum Magistri, D. 15 c. 3, ed. Friedberg, 36-40. The author's use of this distinction seems to be primarily focused on showing how texts with obscure origins have no authority, rather than to include the Mirror in any of the specific groups of texts which are named in the canon. 
the Mirror's doctrines are entirely from the author's own head, without any support from Scripture or the doctors of the Church. Here he uses a quote from Augustine, found in Gratian's ninth distinction, which describes how texts ought not to be believed unless they are proven to be true through scripture or other legitimate authorities. ${ }^{41}$

These are arguments based firmly in textual and authorial legitimacy, and form the first two points of this first section: false doctrine and illegitimacy. But after this initial focus on text and author, the refuter begins to shift to a less distinct separation.

The shift begins with the author bringing in standard legislation regarding the person of a heretic. He notes that the Mirror's lack of support from legitimate authorities means that it is new, invented doctrine, which connects it to the essential definition of a heretic as found in the 27th and 28th canons of Gratian's 24th Causa.$^{42}$ These canons, mainstays of anti-heretical legislation, define a heretic as essentially one who understands Scripture other than how it ought to be interpreted, and who brings forth and follows new opinions ${ }^{43}$ From there he moves to the third focus of his legal assessment: illicit dissemination. Not only is the Mirror false doctrine, but its dissemination of such doctrine doubly marks it as heretical. Here he invokes the image of a false preacher, one who publicly proclaims unsupported doctrine and usurps a role solely designated to churchmen. "How shall they preach, unless they be sent?" he writes, invoking Romans 10:15. As other sects were, the Mirror is cast here as usurping an office of the church in order to spread false doctrine. ${ }^{44}$ It is also specifically cast within the verbal, physical action of preaching. His supporting citation is the 1199 decree Cum ex iniuncto, which, among other things, condemned those who preached without the authority to do so. ${ }^{45} \mathrm{He}$ finishes his consilium with a quotation from Hebrews 13:19: „Be not led away by various and strange doctrines. "By using this line, the author offers a neat cap to the main picture of the Mirror that he has presented in his introduction. The Mirror is an apocryphal, unsupported work, which, like a false preacher, is usurping church office and disseminating "various and strange« doctrines illicitly, which could dangerously "lead away « those reading or hearing it.

In the very beginning of the treatise, then, the Mirror is first presented in terms which characterise both a text - as with the reference to apocrypha and textual authority - and a human agent, as with the image of the false preacher and the "classic « heretic found in Gratian. Obviously, the author of the Paduan text would have been aware that a text has a human author behind it. But near the end of this section, particularly when using the image of the false preacher, his characterisation begins to blur the lines between the two. Is the author the false preacher, or is that the Mirror itself? Is the image of a false preacher merely being used as a representative of illicit dissemination in general, constituted by the text's very existence, or does he envision it - or has he perhaps witnessed it - being read aloud or spread about in other ways? He does not clearly make this distinction by always using the terms "author" or »text«, he merely lets the citations he uses speak for themselves.

\section{1}

43 Gratian, Decretum Magistri, C. 24 q. 3 c. 27, and 28, ed. Friedberg, 997-998; On these canons in the broader antiheretical legal landscape, see Sackville, Heresy and Heretics, 104-107.

44 See, for example, Alain of Lille's criticism of the Waldensians, in Wakefield and Evans, Heresies of the High Middle Ages, 217-220. See also the analysis in Kienzle, Preaching as Touchstone.

45 See Hagender et al., Register Innozenz' III, 273.

medieval worlds • No. $7 \cdot 2018 \cdot 137-152$ 
This foreshadows the rest of his treatise, for on a rhetorical level he does not consistently maintain a dual focus on text and human agent. Instead, he frequently addresses the »human" side of the Mirror, presenting it as an active agent of heresy. Only a few times does the Paduan author refer to the Mirror as »the text« or »little work" (opusculum). In most cases, he addresses the "speaker" of the text itself, but not always as "author" (auctor). The author of the polemic more often employs pejoratives to describe the speaker, which convey a more dynamic figure than simply the image of an author. He unsurprisingly uses »this heretic" (iste hereticus) regularly, but also frequently employs "this wicked spirit" (iste malignus spiritus) and "tartarean [i.e. infernal] spirit" (spiritus tartareus). There is a "voice» at work in the text, such as when he calls one of the Mirror's assertions a »diabolical voice" (vox diabolica) akin to that of Satan in the Garden of Eden. ${ }^{46}$ Who exactly the author envisions as this "voice" is not consistent. Sometimes it seems as though it is a generic "he", a heretic who is speaking about the Simple Soul. But at other points he appears to see the Simple Soul itself as the speaker. The »bestial Soul« (bestialis anima) or "wretched Soul« (infelix anima) "scoffs" (insultat) at the Virtues, "wraps itself in carnal desires" (se involuit concupiscentiis carnalibus), and speaks its doctrines "with a filthy mouth" (polluto ore). The Soul wants to eat and drink and indulge all while expecting to enter heaven without any other works of penance or contrition. ${ }^{47}$ Both images of the Mirror's voice seem to blend together. Both of them also move away from that of a static text and towards the idea of an active agent of heresy.

The blending of person and text is perhaps made clearest in the closing paragraph of the work. Here the author sets down a judgment of the Mirror, writing "We prosecute this heretic with his work, and we relinquish this heretic with his work to be burned by fire « ${ }^{48}$ Here, in the final lines of his polemic, the author does not just pronounce upon the text, but upon "this heretic with his work«, and furthermore mentions the heretic first, then the text. He is also echoing inquisitorial language here, by using relinquimus for "relinquish", a word usually used by inquisitors when they turned condemned heretics over to secular authorities in the expectation that they would then be burned at the stake. Therefore, by the end of the treatise, the author is no longer just referring to an illegitimate text, but now speaks of a heretic and his work, as if there is an identifiable figure which can be sentenced along with his text, even though the text itself is the only "heretic « present.

It is in this personifying construction of the book that he brings in another technique which, though common to anti-heretical discourse in sermons, exempla, and other writings, generally does not often appear in the kind of scholarly refutation format used here, nor in the condemnation of texts. He draws on the classic images and tropes used to characterise the general idea of "the heretic", and employs them frequently and with great energy. These add to his personification of the Mirror, as these topoi were usually used to describe the person of the heretic. ${ }^{49}$ These are embedded in his refutation of doctrinal error, providing a rhetorical counterpart to the legal and intellectual exercises of judgment, disproving error, and revealing truth.

46 MS 1647, fol. 219v.

47 MS 1647, fols. 218v and 220v.

48 MS 1647, fol. 221v.: Hunc hereticum con suo opere persequimur, et hunc hereticum cum suo opere relinquimus igne cremandum.

49 For a summary of these tropes see Sackville, Heresy and Heretics, 154-190. See also Kienzle, Preaching as Touchstone, 45-50, and Grundmann, Typus des Ketzers, 91-107, forthcoming in English translation in Grundmann, Essays on Heresy. 
His attacks are sharp and vitriolic. They are not separate points against the Mirror but are instead woven into and underpin his refutations, adding emotional weight to his intellectual argument. The tropes which occur most frequently are licentiousness, false appearance, corruption, and diabolical inspiration. Abandoning the Virtues provokes the charge of licentiousness. The Simple Soul, which has admitted vice by rejecting the Virtues, "wraps itself in carnal desires " and "cleaves to the flesh and to its works or fruits " (adhesit carni et operibus seu fructibus)..$^{50}$ The Soul eats the »bread of idleness « from Proverbs 31:27..$^{51}$ "Better», he adds, "that it had eaten knowledge of the divine from learned men, than of such barbarous arrogance, and in its ignorance be plunged into the abyss of hell. $\aleph^{52}$ When the Mirror says that the Soul does not seek after anything which is illicit, he declares its real motive to be the desire of illicit things, since its rejection of the Virtues means that it can only desire that which is forbidden and unlawful. ${ }^{53}$

This same statement contains another trope, the image of craftiness and false appearance that first appeared with the mention of the false preacher. He writes that, in saying the Soul does not desire anything which is prohibited, "a snake lurks« in the words of the Mirror, because this qualifying statement implies that the Soul is merely putting up a smokescreen to hide its true desires for illicit, carnal things. ${ }^{54}$ At other points, it is marked as one of those who are of a "double heart " and is the sinner who "goeth on the earth two ways « from Sirach 2:14. ${ }^{55}$ The indifference of the Annihilated Soul to things such as poverty, shame, penances, or honour, is cast in this same light. A claim to indifference based on unity with the divine is "making excuses in sin ", quoting Psalms 140:4, and the Soul's ambivalence is actually just laziness and wantonness. ${ }^{56}$ Its claim to unity is a deception: "It dares to say it is in unity and divinity. I say that it is not united in love, but in the unity of a slave. Those who say such things bring ruin, and may they be ashamed. May death come over them, and may they descend living into hell. « ${ }^{57}$

The trope of corruption is also frequently used, describing the Mirror's assertions as "venom" and "poison" which are "vomited out". The Simple Soul is "manured with so many vices" (tot vitiis stercorata) and presumes to be in heaven "in the dung of the vices" (in stercore vitiorum), and it is fixed deep in "muck" (limo), without any inward cure of good works or salvation. ${ }^{58}$ The author also adds a diabolical element. He makes repeated reference to the Mirror's »devilish tricks« and »diabolical cunning« or »diabolical arts«. Its

50 MS 1647, fols. 220r, 218v.

51 MS 1647, fol. 215v, fols. Manducabit ergo anima ista panem ociosum.

52 MS 1647, fol. 215v.: Melius fuerat ergo manducasse scientiam divinorum a doctis quam in tantam efferi superbiam, et in sua ignorata in profundum inferni dimergi. Arrogance (superbia) was also a telltale sign of the heretic. See Grundmann, Typus des Ketzers, 94-95.

53 MS 1647, fol. 217r.

54 MS 1647, fol. 217r.: Hic latet anguis in verba.

55 MS 1647, fol. 217r.

56 MS 1647, fol. 218v.

57 MS 1647, fol. 220r.: Presumit dicere se in unitatam in divinitatem. Non dico unitate amoris sed unitate serve. Confundantur et erubescant qui ista dicunt. Veniat mors super illos et descendant in infernum uiuentes.

58 MS 1647, fols. 218r and 219r. 
father is the devil, and it maliciously rejects Church teachings and induces people to sin. In claiming that the Soul can become God in indistinct union with the divine, it, like Lucifer, arrogantly aspires to be Godlike, and like the serpent in Eden tempts others to $\sin .^{59}$

These are much more personified images and tropes, and they cast the Mirror's assertions more in the "voice " of an active opponent than an inanimate text. Furthermore, as the intensity of his rhetoric shows, these attacks are not made dispassionately. The author conveys a strong level of emotion, namely scorn, anger, and outrage. He pours an enormous amount of effort into expounding upon the Mirror's filth, its association with the devil, and its falsity.

The tropes he uses are all familiar from other anti-heretical discourses, but, as L. J. Sackville has pointed out, they were sparingly used in the scholarly polemics, which addressed "the content of the heresy, and not the condition of the heretic «. ${ }^{60}$ Furthermore, these tropes were traditionally applied to the person of a heretic, rather than a text. Even when the writings of a particular author were of concern - such as Bernard of Clairvaux's attack on Peter Abelard, where he lamented the "poisonous pages" of his books which "fly abroad « - it is nevertheless the author who is being addressed as the heretic. ${ }^{61}$ But in the Paduan text, the discourse is not presented in the strict image of a heretical "author" generating a text; the heretic here is a rather more blurred and blended figure.

This text, therefore, combines three different identifiable genres/polemical techniques: the legal consilium, the scholarly refutation of doctrinal error, and the classic tropes of antiheretical discourse aimed at the person of the heretic. This reveals layers of purpose. Each technique on its own leaves a gap, but used together each one fills the other's gaps and makes a comprehensive condemnation of the Mirror. He answers the question of the Mirror's overall legitimacy with a legal judgment, but only on the basis of its obscure origins, its inability to be proven by any authority, and its usurpation of the office of preaching. This leaves the challenges of its specific heresies unanswered. He then employs scholarly polemic in order to refute the Mirror's errors and show it to be false and illegitimate on a doctrinal level on top of a legal one.

The third level, the personifying, rhetorical one, seems at first glance to be almost superfluous, an extra frill on the more technical legal and doctrinal polemic. Other anti-heretical polemics constructed rhetorical heretics in which to ground their counter-arguments, but here one would expect the Mirror's excerpts to sufficiently serve that purpose. Instead, the author makes the seemingly unnecessary effort to provide the rhetorical heretic in addition to the text. But in essence this is an important third weapon in the author's textual arsenal. To him, the Mirror was a completely anonymous, apocryphal work. It was not linked to any individual or sect, and so it was a disembodied text which was not anchored to any broader recognisable heresy. In the absence of any known figure, the author constructed one himself. The way in which the Mirror is addressed creates a "living " figure who not only provides a more dynamic opponent for his arguments, but it also underpins the disembodied text with the classic image of "the heretic«. By painting it with the tropes of the generic heretic, the Mirror is no longer a single erroneous book, but is a manifestation of the larger, ever-present enemy of heresy. As a technique, this more fully solidifies his case against the Mirror. If the creator and animating force of the Mirror is an »evil spirit « with all the recognisable

59 MS 1647, fol. 219v.

60 Sackville, Heresy and Heretics, 37 and 39.

61 See Peters, Heresy and Authority, 88. 
hallmarks of a heretic, then this places the final seal upon both its legal and doctrinal illegitimacy. Its errors are not merely wrong and in need of correction, but are the dangerous, "poisonous « words of a "diabolical voice". This means that, by the time the reader gets to the end of the treatise, the impression of the irredeemably evil Mirror is firmly established. This makes the judgment that the heretic and the work ought to be "burned by fire seem both appropriate and necessary.

In addition to refuting the Mirror on all levels, this genre-mixing was perhaps also generated by necessity. As noted above, this text was probably written before 1317 . This means that, at the time of writing, the Mirror would have been a relatively new text, as it is thought to have been composed in the last decade of the thirteenth century, and then perhaps re-written or revised in the first decade of the fourteenth. ${ }^{62}$ Additionally, as noted above, the polemic was likely written before the publication of the Clementine decrees, and therefore before Ad nostrum was available for consultation. Therefore, when the author of this polemic was first confronted with the Mirror, it may not yet have been associated with any particular identifiable heresy, and it had no known author. ${ }^{63}$ Unlike the texts of Cathars, or, later, »beghardian « texts or texts of the Hussites or Lollards, which could be condemned on the basis of their association with certain individuals or known heresies, there was not yet any existing precedent against which the Mirror could be weighed other than more generic declarations on heresy and heretics. This would in a sense demand a more comprehensive approach to its refutation and condemnation, as the case against it had to be built from the ground up.

At the moment, there is no solid evidence pointing to the specific motives and context behind the composition of this text. But these techniques may help to shed a bit more light on them. The Mirror appears in this text as very much a danger, which has the potential to lure others into its error and which promotes and disseminates false doctrine. The author's powerful rhetoric and effort to condemn it on all levels convey a sense of urgency. There is a need here to show the Mirror to be, in his words, "false, deceitful, and heretical " on all levels. The polemic's accusations of deceit and temptation, and its connection of the Mirror to the broader landscape of heresy, hint at something more than rhetoric. It perhaps indicates a concern that that the Mirror had already attracted and influenced a large number of readers. We know from its fifteenth-century Italian circulation that the Latin Mirror circulated across a number of different social circles - lay, semi-religious, and religious - so it is not impossible that in its earlier circulation it appealed to a similarly diverse audience. ${ }^{64}$ The concern driving this text was likely not merely over the Mirror's circulation among the general populace, but amongst learned and religious circles as well. This same diversity in audience for the Mirror may account for the Paduan text's techniques, perhaps indicating that the polemic's own intended audience was both within and outside scholarly circles.

62 Field, Beguine, the Angel, and the Inquisitor, 54; Piron, Marguerite in Champagne, 136-138.

63 As explained in Trombley, New Evidence, 151, it is unlikely that this polemic is associated with Marguerite Porete's two condemnations and trial. Additionally, the author's lack of knowledge of Marguerite and the Mirror's condemnations means he was likely based far enough away from Paris and Valenciennes that no news of these events had reached him.

64 See Guarnieri, Movimento del Libero Spirito, 466-476; Sargent, Medieval and Modern Readership, 93-96, and Trombley, Latin Manuscripts, 206-217; and Trombley, New Frontiers. 
This kind of polemical treatment is - as far as is known - unique in the Mirror's reception history. MS 1647 provides insight into how the Mirror was characterised on a rhetorical level, how in the minds of its opponents it could connect to a broader discourse on heresy, and how it could evoke an emotional and rhetorical response alongside an intellectual one. But it also provides an intriguing deviation from both traditional anti-heretical polemic and the condemnation of texts. In the thirteenth-century polemics, while heretical texts were used in constructing the opposing rhetorical heretic, they serve more as pieces of a larger whole, rather than the sole target of attack. ${ }^{65}$ Even in cases where a specific text is mentioned, as in Salvo Burci's Liber suprastella and Rainerius Sacconi's Summa de catharis et pauperibus de Lugduno, these texts still belonged to the larger, recognisable Cathar heresy, products of heretics rather than independent cases of heresy themselves. ${ }^{66}$ In the case of specific texts being condemned, this often took the form of lists of erroneous propositions rather than polemical discourses, as noted at the beginning of this article. While these condemnations were aimed at texts, it was often - though not always - in connection with the university environment and the teaching of propositions. These propositions were also not always taken from a single text, but drawn from a number of the author's writings. ${ }^{67}$ Text and author were on the whole kept separate, with the author usually escaping severe punishment while the propositions or books were condemned. A condemnation of both text and author as heretical in the same moment - much less wholly diabolical and deserving of execution - was a rare occurrence. ${ }^{68}$ In the polemic found within MS 1647, instead of merely treating the text as just a text, it instead is made to function as both erroneous text and rhetorical heretic, the text as heretic.

A more detailed and wider-ranging comparison of techniques between those used against heretical persons and those used against texts is a subject which merits further study. For now, what we have in MS 1647 offers an interesting case of the two mingling together. It shows a confluence of various anti-heretical polemical tools within one text: the legal, the scholarly, and the rhetorical. What it also reveals is an anonymous text cast in the role of "the heretic", characterised with language and imagery more often used against people. In the absence of an identifiable author, one was constructed, built out of the assertions the Mirror itself made and out of broader definitions and tropes of what a heretic is. The author of the Paduan document mixes styles and creates an image of the Mirror of Simple Souls which is simultaneously that of a heretical text requiring assessment and refutation, and a heretic to be pursued and burned.

65 Sackville, Heresy and Heretics, 26-28.

66 For editions of these texts see Burci, Liber suprastella, ed. Bruschi; Sacconi, Summa, ed. Šanjek.

67 Koch, Philosophische und theologische Irrtumslisten, 423-450; Courtenay, Inquiry and Inquisition, 168-181; Lists were also used for non-academic texts, as can be seen with the case of Nicholas Eymerich's list of Ramon Lull's errors in his Directorium Inquisitorum and the errors taken by Heinrich von Kamp from two libelli written by »beghards«. See Nicholas Eymerich, Directorium Inquisitorum, 256-261; Preger, Beiträge zur Geschichte, 62-63.

68 Despite her execution, this process applied to Marguerite Porete's trial in 1310 as well. Sean Field has shown how carefully William of Paris kept apart judgments on Marguerite's person from judgments on her book, bringing the two together only at her sentencing; and even there, Field points out that it is Marguerite's relapse and contumacy which brings about her condemnation, rather than the content of her book. See Field, Beguine, the Angel, and the Inquisitor, 85-105,125-126. 


\section{References}

Courtenay, William, Inquiry and Inquisition: Academic Freedom in Medieval Universities, Church History 58 (1989) 168-181.

Dascal, Marcelo, On the Use of Argumentative Reason in Religious Polemics, in: Hettema, Theo L. and Van der Kooij, Arie (eds.), Religious Polemics in Context: Papers Presented to the Second International Conference of the Leiden Institute for the Study of Religions Held at Leiden, 27-28 April 2000 (Assen, 2004) 3-20.

Dzon, Mary, Cecily Neville and the Apocryphal Infantia Salvatoris in the Middle Ages, Mediaeval Studies 71 (2009) 235-300.

Field, Sean L., The Beguine, the Angel, and the Inquisitor: The Trials of Marguerite Porete and Guiard of Cressonessart (Notre Dame, IN, 2012).

Gratian, Decretum Magistri Gratiani, ed. Emil Friedberg, Corpus Iuris Canonici, Vol. 1 (Leipzig, 1879). Accessed through the Münchener DigitalisierungsZentrum of the Bayerische Staatsbibliothek. [Accessed 2017 and 2018]

Griguolo, Primo, Per la biografia del canonista ferrarese Giacomo Zocchi († 1457): L'insegnamento, la famiglia, i libri, Quaderni per la storia dell'università di Padova 44 (2011) 181-209.

Grundmann, Herbert, Der Typus des Ketzers in mittelalterlicher Anschauung, in: Kultur- und Universalgeschichte: Festschrift für W. Goetz (Leipzig, 1927) 91-107.

Grundmann, Herbert, »Oportet haereses esse.« Das Problem der Ketzerei im Spiegel der mittelalterlichen Bibelexegese, Archiv für Kulturgeschichte 45 (1963) 129-164.

Grundmann, Herbert, Essays on Heresy, Inquisition, Literacy, ed. Jennifer Kolpacoff Deane, trans. Steven Rowan (York Medieval Press) forthcoming.

Guarnieri, Romana, Il movimento del Libero Spirito, Archivio Italiano per la Storia Della Pietà 4 (1965) 353-708.

Hagender, Othmar, Maleczek, Werner, and Strnad, Alfred A. (eds.), Die Register Innocenz' III, Vol. 2: 2, Pontifikatsjahr 1199/1200. Texte (Vienna, 1979).

Hettema, Theo L., Van der Kooij, Arie, Introduction, in: Theo L. Hettema and Arie Van der Kooij (ed.), Religious Polemics in Context: Papers Presented to the Second International Conference of the Leiden Institute for the Study of Religions Held at Leiden, 27-28 April 2000 (Assen, 2004), xi-xv.

Kieckhefer, Richard, The Repression of Heresy in Medieval Germany (Liverpool, 1979).

Kienzle, Beverly Mayne, Preaching as Touchstone of Orthodoxy and Dissidence in the Middle Ages, Medieval Sermon Studies 42 (1999) 18-53.

Koch, Josef, Philosophische und Theologische Irrtumslisten von 1270-1329. Ein Beitrag zur Entwicklung der Theologischen Zensuren, in: Josef Koch (ed.), Kleine Schriften 2 (Rome, 1973) 423-450.

Lerner, Robert E., The Heresy of the Free Spirit in the Later Middle Ages (2nd edition) (Notre Dame, IN, 1991).

Lerner, Robert E., Meister Eckhart's Specter: Fourteenth-Century Uses of the Bull In agro dominico Including a Newly Discovered Inquisitorial Text of 1337, Mediaeval Studies 70 (2008) 115-134.

Makowski, Elizabeth, When Is a Beguine not a Beguine? Names, Norms, and Nuance in Canonical Literature, in: Böhringer, Letha, Kolpacoff Deane, Jennifer, and van Engen, Hildo (eds.), Labels and Libels: Naming Beguines in Northern Medieval Europe (Turnhout, 2014) 93-94. 
Marguerite Porete, Le Mirouer des Simple Ames/Speculum Simplicium Animarum, ed. Romana Guarnieri and Paul Verdeyen, Corpus Christianorum Continuatio Mediaevalis 69 (Turnhout, 1986).

Marguerite Porete, The Mirror of Simple Souls, trans. Ellen Babinsky (New York, 1993).

Marguerite Porete, The Mirror of Simple Souls, trans. Edmund Colledge, Judith Grant, and Jack C. Marler (Indiana, 1999).

Nicholas Eymerich, Directorium Inquisitorum F. Nicolai Eymerici Ordinis Praed. Cum commentariis Francisci Pegñae (Rome, 1587).

Parmeggiani, Riccardo, I consilia procedurali per l'inquisizione medievale 1235-1330 (Bologna, 2011).

Peters, Edward, Heresy and Authority in Medieval Europe (Philadelphia, 1980).

Piron, Sylvain, Marguerite, entre les béguines et le maîtres, in: Sean L. Field, Robert E. Lerner, and Sylvain Piron, (eds.), Marguerite Porete et le Miroir des simples âmes: Perspectives historiques, philosophique, et littéraires (Paris, 2013) 69-101.

Piron, Sylvain, Marguerite in Champagne, Journal of Medieval Religious Cultures 43/2 (2017) 135-156.

Preger, Wilhelm, Beiträge zur Geschichte der religiösen Bewegung in den Niederlanden in der 2 Hälfte des 14 Jahrhunderts, Abhandlungen der historischen Classe der Königlich Bayerischen Akademie der Wissenschaften 21 (1898) 1-63.

Rainerius Sacconi, Summa de Catharis et Pauperibus de Lugduno, ed. Franjo Šanjek, Archivum Fratrum Praedicatorum 44 (1974) 31-60.

Sackville, Lucy J., Heresy and Heretics in the Thirteenth Century: The Textual Representations (York, 2011).

Salvo Burci, Liber suprastella, ed. Caterina Bruschi, Fonti per la storia dell'Italia medievale, Antiquitates 15 (Rome, 2002).

Sargent, Michael, Medieval and Modern Readership of Marguerite Porete's Mirouer Des Simples Ames Anienties: The Manuscripts of the Continental Latin and Italian Tradition, in: Alessandra Petrina (ed.), The Medieval Translator/Traduire Au Moyen Age: In Principio Fuit Interpres 15 (Turnhout, 2013) 85-96.

Southcombe, George, Suerbaum, Almut and Thompson, Benjamin Introduction, in: George, Southcombe, Almut, Suerbaum and Benjamin Thompson, (eds.), Polemic: Language as Violence in Medieval and Early Modern Discourse (Farnham, 2015).

Stauffer, Robert, and Wendy, Terry R., A Companion to Marguerite Porete and the Mirror of Simple Souls (Leiden, 2017).

Thijssen, Johannes M. M. H., Censure and Heresy at the University of Paris: 1200-140o (Philadelphia, 1998).

Trombley, Justine, The Mirror Broken Anew: The Manuscript Evidence for Opposition to Marguerite Porete's Latin Mirror of Simple Souls in the Later Middle Ages. Unpublished PhD thesis (University of St Andrews, 2014).

Trombley, Justine, New Evidence on the Origins of the Latin Mirror of Simple Souls from a Forgotten Paduan Manuscript, Journal of Medieval History 43/2 (2017) 137-152.

Trombley, Justine, The Latin Manuscripts of the Mirror of Simple Soul, in: Robert Stauffer and Wendy R. Terry (eds.), A Companion to Marguerite Porete and the Mirror of Simple Souls (Leiden, 2017) 186-217. 
Trombley, Justine, New Frontiers in the Late Medieval Reception of a Heretical Text: The Implications of Two New Latin Copies of Marguerite Porete's Mirror of Simple Souls, in: Michael D. Bailey and Sean L. Field, (eds.), Late Medieval Heresy: New Perspectives, Studies in Honor of Robert E. Lerner (Woodbridge, UK, 2018) forthcoming.

Verdeyen, Paul (ed.), Le procès d'inquisition contre Marguerite Porete et Guiard de Cressonessart, Revue d'histoire ecclesiastique 81 (1986) 47-94.

Wakefield, Walter L. and Austin P. Evans (eds.), Heresies of the High Middle Ages (New York, 1969).

\section{Manuscripts}

Padua, Biblioteca universitaria, MS 1647

Vatican, Biblioteca apostolica vaticana, MS Vat. lat. 4953

Vatican, BAV, MS Vat. lat. 4355

Vatican, BAV, MS Rossianus 4

Vatican, BAV, MS Chigianus B IV 41

Vatican, BAV, MS Chigianus C IV 85 


\title{
Transfers of anti-Waldensian material from a polemical treatise to a didactic text
}

\author{
Reima Välimäki*
}

Ulrich von Pottenstein translated Petrus Zwicker's anti-Waldensian treatise Cum dormirent homines (1395) in his large catechetical encyclopaedia (ca. 1410), written in Early New High German. The translation was dispersed in different chapters, transforming the reading experience of the anti-heretical work but at the same time adding a polemical element to a pastoral text.

The article discusses the historical context of Zwicker's original Latin treatise and Ulrich's translation, in particular the inquisitions against Waldensians that Zwicker led in Austria in the 1390 s, as well as Ulrich's ecclesiastical career. The second part of the article explores solutions Ulrich had to employ when he translated a text for a lay audience that was not only polemical but also required from its readers a basic understanding of exegesis. Finally, the reasons for Ulrich's decision to translate Zwicker and the composite nature of the pastoraldidactic text with polemical passages is discussed. As for polemical treatises in general, the motivation behind Ulrich's translation was to defend the Church against its enemies. Ulrich's vernacular text had potential to extend the audience of a Latin anti-heretical treatise, but his catechetical encyclopaedia was too large and tedious to read to ever become a popular work. The article proposes that the polemical nature of the original was not mitigated in the process. On the contrary, Ulrich does not shy away from using denigrating or violent language, and polemical style is an essential part of his catechesis. A further study of polemical style in late-medieval pastoral and didactic works, especially vernacular texts, is proposed as a promising area of future research.

Keywords: heresy; Waldensians; anti-heretical polemics; pastoral care; inquisition; Zwicker, Petrus; Ulrich von Pottenstein; translation; Early New High German, Wiener Schule

\section{Introduction}

At the turn of the fifteenth century Ulrich, parson of Pottenstein in Austria, toiled with his magnum opus. He had set himself to compile what he saw as essential theological knowledge and translate it from Latin into the Early New High German vernacular. The result, when he finished it sometime around 1410, was a huge four-part catechetical treatise. The whole work consists of 70 chapters divided into four parts; Pater noster (chs. 1-13), Ave Maria (14-20), Credo (21-42) and Magnificat/Decalogus (43-70). It covers about 1200 manuscript folios, but it probably never existed as a single manuscript. Despite the fact that it is often designated, * Correspondence details: Reima Välimäki, University of Turku, Department of Cultural History. Email: reima.
valimaki@utu.fi. 
following the fundamental study by Gabriele Baptist-Hlawatsch, as ra catechetical work $\triangleleft{ }^{1}$ perhaps a more fitting description is Klaus Wolf's scatechetical Encyclopediar (Katechetische Enzyklopädie). ${ }^{2}$ The treatise should be viewed more as a German compendium of theological knowledge translated from Latin sources than a practical guide to Christian life and doctrine intended for the laity. ${ }^{3}$ Its gigantic size prevented its transmission. It was simply too massive to be practical and too expensive to produce. The manuscript tradition of Ulrich von Pottenstein's catechetic summa is indeed very small, only eleven extant manuscripts (and one very short fragment), ${ }^{4}$ none of which comprises the whole treatise.

Ulrich drew from a wide range of Latin sources, and he cites extensively patristic and medieval authors. However, the Latin tradition Ulrich translated and transmitted came mainly from three compilations, recognised by Baptist-Hlawatsch: Gratian's Decretum, William Peraldus's popular Summa de vitiis et virtutibus (written before 1250) and an unidentified theological compilation containing at least Thomas Aquinas's Summa theologiae secunda secundae. At times Ulrich inserts longer passages of his own, but often he adds only short introductory or explanatory clauses and loyally translates whole chapters from his sources, to the extent that the treatise occasionally resembles a translation of William Peraldus's work. ${ }^{5}$ In addition to these compilations, Ulrich translated individual treatises or parts from them, only few of which have been recognised. ${ }^{6}$ This article concentrates on transfers of anti-heretical material from a particular text: the Celestine inquisitor Petrus Zwicker's anti-Waldensian treatise Cum dormirent homines, written in 1395. The treatise spread quickly, above all in Austria, Bohemia and Southern Germany, and with its circa 50 manuscript copies it became the standard polemical work on Waldensianism in German-speaking Europe in the fifteenth century. ${ }^{7}$ Ulrich's translation of Zwicker's treatise is an intriguing case, not only in relation to its immediate context, the persecution of Austrian Waldensians, but to the topic of this volume, the construction of polemics and transfers between other genres of literary interaction. The translation is an attempt not only to cross the language barrier between Latin and Early New High German, but also to assimilate a Latin polemical treatise, written against a specific enemy, the Waldensians, into a framework of catechetic summa discussing thematically the key concepts, questions and problems of late medieval Catholic Christianity. setzungsliteratur, 357; Baptist-Hlawatsch, Einführung, 20*-21* and Zwicker's Cum dormirent homines discussed in this article. In addition, Hermann Menhardt found passages treating Cathars that he traced back to the thirteenthcentury treatise by Reinerius Sacconi, see Menhardt, Funde zu Ulrich von Pottenstein, 170-171. It is probable that Ulrich's source was a version of the compilation by the Anonymous of Passau (ca. 1260) that contained Reinerius's treatise. On this compilation, see Patschovsky, Passauer Anonymus; Nickson, >Pseudo-Reinerius Treatise.

7 The fundamental studies on Zwicker's treatise are: Biller, Anti-Waldensian Treatise; Segl, Waldenser in Österreich; Modestin, Anti-Waldensian Treatise; Välimäki, Awakener of Sleeping Men, 77-114. A monograph based on my dissertation will be published by the York Medieval Press in 2019. 
In addition, the assumed and intended audience changed from the clergy to the laity. The exact dating of Ulrich's treatise is not known, but Gabriele Baptist-Hlawatsch has proposed that Ulrich started to compose it during the 1390 s and the whole work was finished before Ulrich received the diaconate at Enns-Lorch in 1411/12. ${ }^{8}$ In any case, we can safely speak of a contemporary reception of Zwicker's treatise.

I will first provide a brief historical context for Zwicker's treatise and Ulrich's translation. I will then discuss how Ulrich assimilated Zwicker's text into his catechetical encyclopaedia. He translated the whole text, but dispersed it across multiple chapters. He also expanded the text, providing further expositions. This changed the nature of the text, and the comparison between the two offers an excellent opportunity to explore the common ground between pastoral-didactic and polemical anti-heretical text. I will conclude the article by discussing the nature of the late-medieval religious polemical genre in the light of Ulrich von Pottenstein's translation. Almut Suerbaum has remarked that the anti-heretical sermons of Berthold of Regensburg were primarily aimed at the lay audience, castigating their mistakes and warning about heresy. ${ }^{9}$ Ulrich's didactic text has a similar function; it both provides guidance on the good Christian life and warns about error. As such, it distances itself from the imagined audiences and goal of Zwicker's treatise, which, at the rhetorical level, addresses the heretics and aims at their conversion and refutation of their errors. In a way, the structure of Ulrich's catechetic encyclopedia is more effective in juxtaposing the desired Christian modus vivendi and heretical error than the conventional anti-heretical treatise.

Ulrich von Pottenstein and his catechetic treatise have mainly been studied by Germanists, and Ulrich is best known for his popular fable translation, Cyrillusfabeln, which, unlike the catechetic treatise, was printed in the incunabula period..$^{10}$ Ulrich was a representative of the Wiener Schule of authors, translators and compilers connected to the University of Vienna, the ducal court and other secular lords and patrons. A central characteristic of the group, according to modern concepts and definitions, was a practically oriented attitude towards theology and other academic disciplines instead of purely scholarly speculation. They offered German devotional literature to lay audiences, although their readers included many members of the clergy and religious orders. The school's representatives include figures such as Thomas Peuntner and Heinrich von Langenstein. ${ }^{11}$ The education of laity, however, did not imply their emancipation. The Wiener Schule's message emphasised the doctrinal authority of the Church. Their vernacular devotional literature avoided controversial questions and guided the laity to orthodox piety as defined and instructed by the clergy. ${ }^{12}$ The previous scholars have commented on the anti-Jewish and anti-Hussite writings of the Wiener Schule, ${ }^{13}$ and my observations on Ulrich's anti-Waldensian translation expand our understanding about the role of the group in support of the state and the Church in early-fifteenth-century Austria.

8 Baptist-Hlawatsch, Einführung, $20^{*}-22^{*}$.

9 Suerbaum, Language of Violence, 128, 130. See below.

10 Baptist-Hlawatsch, Einführung, 13; Bodemann-Kornhaas, Cyrillusfabeln, 55-73.

11 On the Wiener Schule and its mission, see Hohmann, Bemerkungen zur Übersetzungsliteratur; Wolf, Hof - Universität - Laien; Wolf, Die sstaatstragender Rezeption.

12 Williams-Krapp, Observanzbewegungen, 14-15; Williams-Krapp, Zur literarischen Laienpastoration, 81-83; Wolf, Hof - Universität - Laien, 137.

13 See $n .36$ below. 
The connection between the Cum dormirent homines and Ulrich von Pottenstein's catechetic work is not actually a recent discovery. Hermann Menhardt pointed it out in 1953, although he followed the then prevailing false attribution of Cum dormirent homines to Peter von Pillichsdorf, a Viennese theologian and university scholar. ${ }^{14}$ Menhardt also presented a collation of Zwicker's treatise (following the page numbers of the 1613 edition) and the Credo part of Ulrich's treatise according to its earliest and most complete manuscript copy in Cod. 3050 of the Austrian National Library. ${ }^{15}$ He noticed that Ulrich had translated almost the complete text of Zwicker's treatise, but despite his meticulous work Menhardt was unable to locate the last chapter of the Cum dormirent homines, the chapter on denial of oaths. This led him to speculate whether it had been lost with the last, ripped-off quire of Cod. 3050, or whether Ulrich never used it. ${ }^{16}$ Ulrich did indeed translate Zwicker's defence of oath-taking, but not, unlike all other chapters, for the Credo part, but for his exposition of the Decalogue. ${ }^{17}$

However, since Menhardt, only passing remarks on the heresy sections in Ulrich's treatise have been made. Peter Segl referred to them in a paper published in 2006, suggesting further study on the topic. ${ }^{18}$ There were at least two attempts to edit the parts including the translation from the Cum dormirent homines in the 1990 s as a part of larger research projects at the University of Würzburg-Eichstätt, but the prepared edition was never completed. ${ }^{19}$ There are editions of the Pater noster-part and the First Commandment, but these do not include the anti-Waldensian sections. ${ }^{20}$ After Menhardt, my dissertation has been the first study to address Ulrich's translation of the Cum dormirent homines in any detail. ${ }^{21}$ There my focus was on Ulrich von Pottenstein's role in the dissemination of Zwicker's anti-Waldensian message, while this article concentrates on Ulrich's translation as a pastoral text verging on the polemical.

Petrus Zwicker, Ulrich von Pottenstein and the persecution of Austrian Waldensians in the 1390 s Ulrich von Pottenstein rose among the ranks of the Austrian clergy at the turn of the fifteenth century. His career took place at a time when it was impossible for a clergyman of his status not to run across the Waldensians and their persecutors. There had been Waldensians in Austria at least from the second half of the thirteenth century onwards. An author who probably was an inquisitor and a Dominican, but who is known only as the Anonymous of Passau,

14 Menhardt, Funde zu Ulrich von Pottenstein, 159-170; see also Baptist-Hlawatsch, Katechetisches Werk, 6; Schmidtke, U. v. Pottenstein; Ernst, Ulrich von Pottenstein, 209; Segl, Waldenser in Österreich, 186-187.

15 Menhardt, Funde zu Ulrich von Pottenstein, 167-168; ÖNB Cod. 3050 is considered to be the most trustworthy exemplar of the Credo-part, and closest to the author's text, see Baptist-Hlawatsch, Katechetisches Werk, 13-20.

16 Menhardt, Funde zu Ulrich von Pottenstein, 167.

17 Ulrich von Pottenstein, Dekalog, 2. Gebot, Cap. L. Transcription of Kalocza Cod. 629 by SFB 226.

18 Segl, Waldenser in Österreich, 186-188.

19 With the permission of the former project leader, Professor Dieter Harmening, I have consulted the transcriptions prepared first in the Sonderforschungsbereich 226 at the beginning of the 1990 s and later around 2000 in an unfinished dissertation project by Christine Wolf, supervised by Harmening.

20 Ulrich von Pottenstein, Dekalog-Auslegung, ed. Baptist-Hlawatsch; Ulrich von Pottenstein, Paternoster-Auslegung, ed. Hayer

21 Välimäki, Awakener of Sleeping Men, 216-230. 
wrote against them around $1260 .{ }^{22}$ In the following century and a half, dissident communities persisted despite occasional persecutions and setbacks, such as the conversion of a group of Waldensian brethren to Catholicism during the 1360 s, possibly due to the inquisitor Henricus of Olomouc's activity. ${ }^{23} \mathrm{~A}$ new series of trials started in the diocese of Passau around 1395 when Petrus Zwicker was nominated as inquisitor of heresy. ${ }^{24}$ Between 1395 and 1398 Zwicker, assisted by Fridericus, a Benedictine monk from Garsten, interrogated probably hundreds if not thousands of Waldensians around Garsten, Steyr and Enns. Only fragments of trial documents survive in formularies compiled from selected sentences, but contemporary and later chronicles recount one thousand convicted and between eighty and one hundred burned heretics. In addition, in the sixteenth century, three large volumes of trial documents - since lost - existed at the library of the Benedictine monastery of Garsten. Even if the numbers recounted in chronicles are probably rounded-up and exaggerated and the information about original depositions at Garsten is vague and unreliable, compared to the over 450 Waldensians Zwicker interrogated in Stettin in 1392-1394 an estimate of several thousand deponents in the more populous Upper Austria region is not an exaggeration. ${ }^{25}$

Petrus Zwicker returned to Austria and its neighbouring areas with another inquisitor, Martinus of Prague, in January 1401, when they sentenced heretics to do public penance by wearing crosses in Ödenburg (now Sopron, Hungary) in the diocese of Györ. In February of the same year, they were at Hartperg in Styria, in the Archdiocese of Salzburg, where three women ended up on the pyre as relapsed heretics and opponents of the inquisitors. ${ }^{26}$ Finally, Zwicker proceeded against a man called Andreas Hesel in Vienna in $1403 \cdot{ }^{27}$ In the diocese of Passau, trials against heretics continued after Petrus Zwicker's death in around 1404. In February 1408, the Landeshauptmann Reinprecht II of Wallsee received oaths of truce and abjuration of all heresy from a widow and her three children who had been imprisoned because of their heresy - her husband and their father had been burned for his heresy. ${ }^{28}$ Reinprecht II of Wallsee was one of the most influential Austrian noblemen in Petrus Zwicker's and Ulrich

22 On the Anonymous's treatise, see Nickson, >Pseudo-Reinerius` Treatise; Patschovsky, Passauer Anonymus; on heretics in Austria in the second half of the thirteenth century, see Segl, Ketzer in Österreich, 165-233.

23 Biller, Aspects, 226; on Henricus of Olomouc, see Haupt, Waldenserthum und Inquisition, 368-369; Gonnet and Molnár, Vaudois au Moyen Âge, 150, 157; Segl, Waldenser in Österreich, 176-177; Modestin, Anti-Waldensian Treatise, 225-226.

24 Since H. Haupt's seminal work on Austrian Waldensians, the beginning of Zwicker's inquisition in the diocese of Passau has been dated to 1391, see Haupt, Waldenserthum und Inquisition, 370, 404; Biller, Anti-Waldensian Treatise, 255; Segl, Waldenser in Österreich, 177; Modestin, Ketzer in der Stadt, 4; Modestin, Peter Zwicker, 28; Modestin, Anti-Waldensian Treatise, 217. The year 1391 is, however, based on a misinterpretation of dates in Zwicker's formulary of sentences. The inquisitions in the diocese of Passau took place in 1395-1398, and the first version of the formulary was compiled soon after that, see Välimäki, Awakener of Sleeping Men, 167-172.

25 Segl, Waldenser in Österreich, 172-184; Välimäki, Awakener of Sleeping Men, 164-174; the chronicle sources are an almost contemporary Austrian chronicle, see Österreichische Chronik von den 95 Herrschaften, ed. Seemüller, 221; and the seventeenth-century Valentin Prevenhuber's Annales, which probably make use of medieval sources, see Preuenhueber, Annales Styrenses, 72.

26 The documents are edited in Haupt, Waldenserthum und Inquisition, 401-403, 408-411.

27 The sentence has been preserved in a single manuscript, Würzburg UB, M. ch. f. 51, fols. 27v-28v. Ed. partially in Döllinger, Beiträge II, 343-344.

28 Vienna, Österreichisches Staatsarchiv, Haus-, Hof- und Staatsarchiv, Allgemeine Urkundenreihe, 1408 II 17; cf. Doblinger, Herren von Walsee, 399; Segl, Die Waldenser in Österreich, 175. For more details, see Välimäki, Awakener of Sleeping Men, 43-44. 
von Pottenstein's lifetime. He was also the lord of the town of Pottenstein, and he donated a plot in Enns so that Ulrich could build a townhouse for a chaplain. In turn, Ulrich established masses for Reinprecht's benefit in his last will in 1416, and one of the manuscripts of his catechetical treatise was dedicated to Reinprecht. ${ }^{29}$

Reinprecht II of Wallsee was not the only mighty and powerful patron Ulrich had. As parson of Pottenstein, Ulrich was a member of the Chapter of St. Stephen in Vienna from the beginning of the 1390s until December 1404, when he was nominated parson of Mödling. Ulrich was closely connected to the ducal court as chaplain of Duchess Beatrix, wife of the deceased Duke Albrecht III, ${ }^{30}$ as well as of Duke Albrecht IV. ${ }^{31}$ As a canon at the cathedral of St. Stephen, Ulrich can hardly have remained ignorant of the trial of Andreas Hesel and his punishment by Petrus Zwicker in the presence of a great multitude of clergy and laity in Vienna in March 1403, although Ulrich is not mentioned among the witnesses. ${ }^{32}$

There has been speculation that Ulrich's anti-Waldensian literary activity might have been motivated by personal gain, namely that Ulrich got hold of some property confiscated from the Waldensians. As parson and dean of Enns-Lorch he did indeed create new benefices and in his testament (1416) he donated significant property to a new chapel in the Church of St. Mary at Enns, property that he had acquired during the preceding years in Upper Austria. Ulrich's patron, the aforementioned Reinprecht of Wallsee, had been Landeshauptmann (governor) at Enns since 1380, and thus responsible for dispensing secular justice in the inquisitions of heresy, including possible confiscations of property. ${ }^{33}$ We cannot, however, be sure if property of the convicted heretics was confiscated at Enns. There were inquisitions in the town, but the only references are brief remarks in Zwicker's later sentences. ${ }^{34}$ In any case, Ulrich would have arrived at Enns too late to gain anything directly from possible confiscations. He received the offices at Enns only in 1411 or 1412, well after he had finished his catechetic summa. ${ }^{35}$ His anti-Waldensian inclinations thus arose from motives other than personal financial gain, but at a general level his writings supported the same goals as the judicial repression of dissidents by secular authorities. The authors and translators of the Wiener Schule wrote practically-oriented theology that was fundamentally in support of the state (a "staatstragende" theology, pace Klaus Wolf). This meant defending the unity of faith

29 Baptist-Hlawatsch, Das Katechetische Werk, 2, 4-5, 53-54, 57.

30 Baptist-Hlawatsch, Einführung, 1*-4*; Baptist-Hlawatsch, Katechetisches Werk, 2-4; Ernst, Ulrich von Pottenstein, 206; Menhardt, Funde zu Ulrich von Pottenstein, 146-147.

31 Lackner, Hof und Herrschaft, 157.

32 Würzburg UB, M. ch. f. 51, fol. 28r: presentibus honorabilibus et discretis viris et dominis petro Schulderwerem plebanus in stewestarff (?), ulrico de gretz et henrico dicto albus predicatoribus apud dictam ecclesiam sancti Stephani et quampluribus fidedignis aliis testibus clericis et laicis ac maxima multitudine hominum plebis dicte parochie ibi ad audiendum verbum dei congregata.

33 Menhardt, Funde zu Ulrich von Pottenstein, 147; Ernst, Ulrich von Pottenstein, 207; Segl, Waldenser in Österreich, 173-175.

34 The only person certainly convicted at Enns was Jans von Pewg, whose sentence for perjury in January 1398 tells that he had first abjured heresy at Enns »one and half years earlier «, see St. Paul, Cod. 77/4, fol. 330va: recognouisti quod ante alterum dimidium annum ex nostro mandato per plebanum tuum vocatus ad nostrum veneris examen ad Anasium et ibi coram nobis de didenda ueritate secundum quod iuris est.

35 On Ulrich's nomination as parson and dean at Enns, see Baptist-Hlawatsch, Einführung, $5^{*}-6^{*}$. 
in the realm and fighting superstition. The anti-Jewish and anti-Hussite endeavours of the university are well known, but Klaus Wolf mentions only briefly the earlier repression of the Waldensians in his extensive study on the Wiener Schule. ${ }^{36}$ Yet precisely this is the broader religious-political context of Ulrich's translations.

Although there is no evidence that Petrus Zwicker and Ulrich von Pottenstein ever met personally, or that Ulrich himself was ever directly involved in prosecuting Waldensians, Ulrich's career contains multiple occasions with the potential for encounters with suspected, convicted or converted Waldensians. Due to the inquisitions that lasted for years, with the accompanying sermons, citations, declarations of sentences and supervision of penances, ${ }^{37}$ the Waldensians inevitably belonged to the contemporary clergy's experience in Austria. This explains the popularity of Zwicker's texts in Austria and Southern Germany, as well as Ulrich's decision to translate the Cum dormirent homines and incorporate it into his catechetical treatise. The treatise was available to him relatively easily: the earliest copies of the Cum dormirent homines date to the time when Ulrich composed his treatise. A few come from Austria, although none of them is the exemplar Ulrich used. ${ }^{38}$

\section{Translating heresy}

How does one fit a polemical treatise into a catechetical compendium? The first remarkable thing is that Ulrich did not simply quote short passages from the Cum dormirent homines but translated practically the whole treatise. Secondly, it is equally remarkable that he did not translate it as a unit. There is no one single book or chapter on Waldensians, but chapters of Zwicker's treatise are divided and assimilated under various different topics. Neither did Ulrich follow the order of the Cum dormirent homines. Several chapters precede the translation of the beginning of Zwicker's treatise, and thus his prologue and introduction to the history of Waldensian movement.

The beginning of the Cum dormirent homines, along with several other chapters, was translated in the Credo part in chapter $35 .{ }^{39}$ However, long passages from the treatise precede this in Ulrich's work. For example, the Cum dormirent homines' chapter about burial in consecrated ground is inserted into the Credo chapter 27, treating different aspects of Christian burial according to the example set by Christ's tomb after his crucifixion. Waldensians are simply inserted into the text without any previous warning or explanation to the reader. Chapters immediately preceding the translation from Zwicker's treatise deal with whether or not executed criminals can be given Christian burial, and if women who died while pregnant could be buried with their foetus. Only a short introduction leads the reader to anti-heretical sections, from pastoral and canon legal reflections into theological refutation of Waldensian doctrine:

36 Wolf, Hof - Universität - Laien, 118-130 (in general), 193-194 (on Waldensians); on Ulrich von Pottenstein against superstition, see Lasson, Superstitions Médiévales, 205-416.

37 On the various fora of an inquisitor's communication, see Välimäki, Awakener of Sleeping Men, 184-213.

38 Seitenstetten, Cod. 213, fols. 108va-133ra; St. Florian, XI 234, fols. 93ra-112rb; Vienna ÖNB, Cod. 5393, fols. 287va-305vb; Zwettl, Cod. 185, fols. 121rb-141rb.

39 Including Chapters 1-18, 25-29, and 31-35, according to the division in Petrus Zwicker, Cum dormirent homines, ed. Gretser. 
However much burial has a deep and solid foundation in the Old and New Testaments and in holy laws, nevertheless the impious Waldensian heretics speak against it and suppose in their error that a corpse of a dead person is not better buried in a church or in a graveyard than in a field or some other place. ${ }^{40}$

This reveals the tension between Ulrich's goal of bringing Latin learning to the laity and the practical solutions he employs. His translation from Zwicker made available to the reader what was in fact one of the best medieval introductions to what Waldensians were, but in Ulrich's schema it is situated over 150 folios apart from the sudden appearance of the heretics in the discussion of burial. Other topics from Zwicker's treatise were also scattered: the chapters on the consecration of churches (Cum dormirent homines: 23), altars (24) and on the veneration of Mary and the saints (19) and of God (20) are all dispersed within Ulrich's chapter 33 on the verse Ich gelaub in die heyligen gemainen kyrchen, gemainschafft der heyligen (I believe in the holy Catholic Church, and the communion of saints) ${ }^{41}$ When encountering one of these topics, the reader is simply assumed to know what the simpious Waldensian heretics « were. The Vienna manuscript anticipates some confusion. Marginalia are rare in this manuscript, but here the scribe has given a Latin rubric when the discussion on Waldensians begins in the chapter on burial: Contra waldenses de sepultura..$^{42}$

Yet here one has to remember that to the immediate contemporaries of Ulrich the reference to Waldensians might have been as clear as day. As stated above, Waldensians were a public concern, and in Austria at the turn of the fifteenth century the whole apparatus of citations, inquisitor's preaching and public penance made it hard to be ignorant of heretics. A Western audience of the twenty-first century has a preconception of what an Islamist terrorist is - similarly the Austrian audience at the turn of the fifteenth century must have had some impression about the Waldensians. It was most likely a one-sided and distorted conception, but nevertheless something that helped to situate an abrupt mention of Waldensians into a larger scheme of things.

When an anti-heretical treatise was translated and incorporated into a catechetic summa, one would anticipate some compromises with regards to the polemical language. Moreover, Zwicker's trademark is a personal, dialogical and disputing style, where he addresses his heretical opponents in the second person - Zwicker adopted this style from one of his sources, the Adversus Catharos et Valdenses by Moneta of Cremona, while the more common solution in contemporary anti-heretical treatises was to speak about heretics in the third person. ${ }^{43}$ However, against this expectation, Ulrich preserved both these stylistic features in his German version. Let us look at one passage where Waldensian counter-argument on secret preaching is answered, followed by a comparison of heretics to nocturnal animals.

\footnotetext{
40 Ulrich von Pottenstein, Credo, Cap. 27M, ÖNB Cod. 3050 fols. 103va-vb: Wie wol die begrebnuss aus der alten ee vnd aus der newen ee vnd aus den heyligen rechten ainen tewffen vnd vesten grunt haben, dannoch widersprechen ir die vnseligen keczer Waldenses vnd halden daz in irem irrsal, daz aines toten menschen leichnam nicht paz begraben werd in ainer kirchen oder in ainem freythof denn in ainem akcher oder an ainer andern stat.

41 Ulrich von Pottenstein, Credo, Cap. 33, ÖNB Cod. 3050 fol. 244ra-259ra.

42 ÖNB Cod. 3050, fol. 103vb.

43 Biller, Anti-Waldensian Treatise, 258-261; Välimäki, Awakener of Sleeping Men, 81-82.
} 
Petrus Zwicker, Cum dormirent homines, ed. Gretser, 279G

Sed dicis Waldensis haeretice: Tamen Christus docuit Nicodemum in nocte de Sacramentorum exordio, scilicet de Baptismate, Ioann.3.

Respondeo, Christus non venit ad Nicodemum sed Nicodemus ad Christum. Tu vero fur et latro, lupe, glis et vespertilio, noctua caeca nocte ad simplices volias, cursitans circuis quaerens quem deuores.

Ulrich von Pottenstein, Credo, Cap. 35C, ÖNB, Cod. 3050, fol. 278vb:

Da wider sprichst du keczer Waldensis: Nu leret doch Christus Nychodemum bey der nacht von dem aneuang der sacrament, von der tawffe, Iohannis iijo.

Die antwurt: Christus cham nicht zu Nychodemo, aber Nychodemus cham zu im. Aber du dewb vnd schacher, fuchs, fledermaws vnd nachtrab, du flewgest plint des gelauben des nachtes czu den ainueltigen. Du lawffest vmb vnd vmb vnd suchest, wen du czu reissest.

[English translation of Ulrich's text:] Against that speak you, Waldensian heretic: [saying] after all, Christ taught Nicodemus at night about the origin of the sacrament, baptism, John 3.

The answer: Christ did not come to Nicodemus, but Nicodemus came to him. But you, thief and robber, fox, bat and owl, you fly blinded by the faith of night to the simple people. You go around and around and seek out, whom to snatch away.

The second person and denigrating language are preserved: both in Latin and in German, the heretic is compared to criminals and nocturnal animals, moving around and seeking victims to devour. But while thief and robber (fur et latro) are translated with corresponding German words (dewb vnd schacher ${ }^{44}$ ), some creativity is used in translating the night animals. The wolf becomes a fox, the glis (a dormouse) is dismissed, but the bat and the owl (vespertilio, noctua) are both translated (fledermaws vnd nachtrab). The dismissal of the glis may be a simple accident, but it may also be that the Latin word carried a connotation of a secretive night animal while the contemporary German did not. After all, the small, big-eyed rodent is not very intimidating.

Also the blindness is explained a bit more than in Zwicker's Latin. Here, the heretic/ night animal is simply sblinded by night ( caeca nocte), while in Ulrich's German ‘blinded by the faith of night ( plint des gelauben des nachtes). This is obviously also the connotation in Zwicker's polemical language. But the Latin, written for a clerical audience, allowed metaphors that remained implicit, whereas the German prose of the Wiener Schule aimed for unambiguous, uncontroversial devotional literature that a lay audience could read without fear of error and misinterpretation. ${ }^{45}$ Ulrich was loyal to this ideal. The need to expand the original text in order to be intelligible is even more visible in the translation of a metaphor where Zwicker blames Waldensians for claiming that in heavenly joys, saints forget those living on earth, ras if they, when things prospered with them, would have forgotten us, as Pharaoh's chief cupbearers forgot Joseph, his imprisoned interpreter, Gen. 40. ${ }^{46}$ The story

44 More likely to be read as Schächer (robber, thief) than Schacher (usurer). The latter reading would add another polemical layer to the text with an allusion to Jews.

45 Wolf, Hof - Universität - Laien, 188-189.

46 Petrus Zwicker, Cum dormirent homines, ed. Gretser, 286B-C. 
behind the metaphor is of Joseph interpreting correctly that the dream of Pharaoh's imprisoned cupbearer foretold his release, and that the cupbearer in his freedom forgot Joseph against the latter's wish. Ulrich translates the passage: "as if they would forget us in their fortune, as Pharaoh's chief cupbearer did pious Joseph, who forgot him in the prison, although he had explained his [cupbearer's] dream and prayed for him, that he would remember him. ${ }^{47}$ Although Ulrich's translation with its several male pronouns referring to different persons is more confusing than Zwicker's original, it seems that the good intention was to explain the story in greater detail than Zwicker. Obviously the challenge with Zwicker's biblicist polemical language was the preliminary knowledge of exegetical and glossing tradition it required from its reader. ${ }^{48}$ This knowledge could not be expected of a layperson. Ulrich attempted to solve this problem, but the result was not very accessible literature, despite his own wish to write den gemainen lauf dewtscher sprach nach des lanndes gewonhait and in the way one should preach to the people, and avoid a too-learned vernacular. ${ }^{49}$

That Ulrich translated not only the content of his source but also the style is in accordance with the previous conclusions drawn from his use of sources: Gabriele Baptist-Hlawatsch has pointed out how loyally Ulrich copied the style of William Peraldus's Summa de vitiis et virtutibus..$^{50}$ In other words, there are changing registers of speech and style in Ulrich's compendium. However, the polemical style and colourful rhetoric in general do not seem to have been foreign to Ulrich. Also, in parts that he possibly wrote himself, such as a lamentation about the bad prelates of his own day in the Pater noster part, Ulrich uses language that is not catechetic, guiding or normative, but outright polemical. Prelates, who oppress the poor people more than godless pagans, are like vultures devouring their children. Some are compared to bats that live in the dark places of the churches, enjoying prebends and loving darkness because of the dirty carnal deeds they commit there. Like bats, they are blind, not knowing the scriptures..$^{51}$ Notably, the same German word fledermaws is used both for bad prelates and for the heretics. The comparison of darkness, nocturnal gatherings, animals, and sexual sins is a lasting element of anti-heretical literature from late Antiquity onwards..$^{52}$ At times, Ulrich is more polemical than his source, the inquisitor Zwicker, who was careful to limit his attack to the Waldensians and avoid mentioning the shortcomings of the contemporary Church, of which he was more than aware. The opening clause of Cum dormirent homines, 'when men were asleep<, alluded in medieval exegesis to the negligence of the clergy as the cause of heresy, but in the Latin treatise the reference remains implicit. ${ }^{53}$

47 Ulrich von Pottenstein, Credo, ÖNB Cod. 3050, fols. 258va-vb: Recht als ob si vnser vergéssen in irem gelücke, als der obrist schenke Pharaonis tet dem frumen Ioseph, der sein vergaz in dem karcher, wie wol er im seinen trawm hette warhafftleichen erleget vnd pat in, daz er sein gedęchte.

48 On Zwicker's biblicism, see Välimäki, Awakener of Sleeping Men, 98-109.

49 Ulrich von Pottenstein, Dekalog-Auslegung, ,Vorrede،, ed. Baptist-Hlawatsch, 2-3; see also Baptist-Hlawatsch, Einführung, 36*-39*; Wolf, Hof - Universität - Laien, 194; cf. Lasson, Superstitions Médiévales, 72-73, who accepts Ulrich's own statement of his style.

50 Baptist-Hlawatsch, Einführung, 30*-36*, 425; see also Wolf, Hof - Universität - Laien, 345-355.

51 Ulrich von Pottenstein, Paternoster-Auslegung, Cap. 7D, ed. Hayer, 154-157.

52 See e.g. Kahlos, Nocturnal Rituals; Grundmann, Typus des Ketzers, 322-325; Utz Tremp, Von der Häresie zur Hexerei, 31-32.

53 Välimäki, Awakener of Sleeping Men, 226, 269-270. 
In his translation, however, Ulrich von Pottenstein significantly expands the exposition of the parable and makes it clear that heresy and error spread when the prelates are negligent, obscene or weighed down by sins. ${ }^{54}$ Not only heretics, but also sinful clerics received the polemical edge of Ulrich's catechesis, and his attack on bad clerics seems deliberate. When translating Peraldus's Summa, Ulrich did not leave out sections that describe the vices of priests and religious orders - unlike some other vernacular versions of Peraldus's Latin treatise. ${ }^{55} \mathrm{An}$ open criticism of the clergy in vernacular by a clergyman himself holding relatively high offices is indeed intriguing, but perhaps not as radical as one might think. Ulrich's lay audience, at least those who could afford to buy his treatise, was not common craftsmen but well-off burghers and nobility who had interests in the affairs of the Church.$^{56}$ Nevertheless, refuting Waldensians served a purpose. Ulrich could condemn the dangerous, heretical anticlericalism while at the same time launching an attack on corrupt members of the Church.

Ulrich thus resorted to literary devices of a polemical style, also in some of his original passages. This leads us to reflect on why Ulrich chose to incorporate an anti-heretical polemic into a catechetical treatise, and how Ulrich's work can be placed within the discourses that modern scholars define as polemics.

\section{Pastoral polemics}

The goal that Ulrich sets for his work in his Preface is to compile a book that would serve only its reader's soul and its eternal salvation - as opposed to the immoral tales of war (streytbüchern) Ulrich saw his contemporaries reading. ${ }^{57}$ The incorporation of Zwicker's treatise must be thought about in the light of this goal. Ulrich in fact gives a short explanation for why he has written so much about heresy. At the end of the long Chapter 35, where the bulk of the Cum dormirent homines is translated, Ulrich tells his reader:

But that I have written so long and so much about heretics in this chapter: I am driven to this, because they are those who in so many ways, so deceitfully and mischievously oppose the universal holy Christian Church, which is the only dove which alone is beautiful, which alone is transcendent (auszerwelt), which alone is without wrinkle and without blemish, and they defile her (the Church) in all her parts, her glory and order, wherever and how often they are capable. ${ }^{8}$

54 Ulrich von Pottenstein, Credo, Cap. 35A, ÖNB Cod. 3050, fols. 276rb-va: „Do aber die lewte slieffen «, daz ist die hüter, die czu der hüt geordent sein vnd den die huet empholhen ist, daz sein die prelaten, der slaf vnd vmbesichtichait machet, daz der veintleich mensch, der tewfel, raten saet, wenn die prelaten slaffen, wenn sy tregge sind. Wider die spricht Salomon Prouerbiorum vj': "Lawf, eyl, wekche deinen frewnt. Gib deinen awgen chainen slaff." Oder wenn sy der vnkewsch phlegen. Da wider ist Amos capitulo vj': "Ir seyt die, dy da slaffen in helfenpaynein petten vnd seyt gail darinnen. "Oder wenn si mit sünden besweret werden. Da wider ist is Paulus $2^{\circ}$ Thessalonicenses iij: "Wir sullen nicht slaffen als dy andern, aber wir sullen wachen vnd mässig sein."

55 Baptist-Hlawatsch, Einführung, $35^{*}$.

56 In addition to the lay elite, many sections of the treatise were clearly primarily intended for the clergy, see BaptistHlawatsch, Einführung, $36^{*}-37^{*}$.

57 Ulrich von Pottenstein, Dekalog-Auslegung, ,Vorredes, ed. Baptist-Hlawatsch, 2.

58 Ulrich von Pottenstein, Credo, 35, ÖNB Cod. 3050, fol. 289va: Daz aber ich so lang vnd so uil in dem capitel von den keczern geschriben han, darczu hat mich geübt, wann si sind dü, die der gemainen heyligen christenleichen kirchen, die ain ainige tawbe ist, die allain die schön ist, die allain die auszerwelt ist, die allain an alle runczen ist vnd an mail, so gar manigueltichleich, listichleich vnd schalkchleich widersprechen vnd si lestern in iren glidern vnd in irer czir vnd ordnung, wa vnd wie offte si daz volbringen mügen. 
The goal motivating Ulrich was thus the usual reason for writing Christian apologetics: to defend the Church against its enemies. But because of the decision to divide the Cum dormirent homines' structure, the end result was a very different reading experience from a more usual anti-heretical text. For example, Zwicker's treatise proceeds from the history of the Waldensians and their claims of being legitimate followers of the apostles to individual heretical opinions and Catholic counter-arguments. A full polemical treatise such as the Cum dormirent homines usually aimed to provide a complete representation of heretics and especially their doctrine, which was then systematically refuted..$^{59} \mathrm{~A}$ reader who encountered Ulrich's translation may only have read, for example, the chapter on Christian burial. Ulrich never intended his work to be read as a whole, but thematically. He prepared an index for the whole work, using alphabetically organised Latin-German keywords (for example: aqua) Wasser) and references to chapter number and letter. The index for the whole work has not been preserved, only indices for individual parts, but Baptist-Hlawatsch has reconstructed the register. ${ }^{60}$

However, if the goal of polemical engagement is understood as establishing "an identity, defined against the wrong or wicked «, ${ }^{61}$ Ulrich's sturcture has even greater polemical potential than many texts usually defined as anti-heretical polemics. By dispersing the chapters of the Cum dormirent homines, by integrating the negative image of heretics within chapters giving positive, normative guidelines for a good Christian life, Ulrich juxtaposes the heretical and the orthodox in a way that does not manifest itself in conventional anti-heretical polemic. Waldensianism as a negative image of the Church, created by a sort of snormative inversion<, to employ a term used by Jan Assmann, ${ }^{62}$ is implicit in the Cum dormirent homines, as well as in the shorter descriptions of Waldensians circulating at the time. All of them accuse the Waldensians of denying practically every important aspect of late medieval religious life. Although not creating a complete counter-society like the authors discussed by Assmann there was after all no denying that the Waldensians upheld baptism and the Eucharist - these descriptions employ the logic that things venerated by Catholics such as church buildings or sacerdotal vestments must be despised and condemned by the heretics. Yet, it is only in Ulrich's catechism that this message becomes explicit.

A combination of pastoral, didactic and polemical voices is not unique. Recently, Almut Suerbaum has found such a combination in the sermons of one of the most successful mendicant preachers of the thirteenth century, the Franciscan Berthold of Regensburg. His vernacular sermons were pastoral care for urban communities where he preached, but his language has two different tones: one castigating the shortcomings of the attending laity, and another attacking the heretics and their false beliefs. The latter message was, of course, also aimed at the Christian listeners. Berthold's sermons do not attempt to persuade heretics to convert, but focus on warning the Catholic audience to avoid heretics' mistakes for the good of their own souls. ${ }^{63}$ There is a comparable shift of emphasis and audience from Zwicker's

59 Sackville, Heresy and Heretics, 13-40.

60 Baptist-Hlawatsch, Katechetisches Werk, 209-322; see also Wolf, Hof - Universität - Laien, 193.

61 Southcombe et al., Introduction, 6; Steckel, Concept of »Polemic«.

62 Assmann, Moses der Ägypter, 57-58, 90.

63 Suerbaum, Language of Violence, 128, 130. 
Cum dormirent homines to Ulrich's translation. Even though the readership of Zwicker's treatise must have consisted of Catholic clergy, the text addresses Waldensians. Stylistically it is a debate, and at least in theory, an attempt at persuasion to convert. Although Ulrich preserved the second person ( $d u$ keczer) the division of anti-Waldensian sections under different topics means that the primary function of the polemic was to warn a Christian reader. If a heretic was the imagined audience of Zwicker's refutation, Ulrich hardly had such a reader in his mind.

Incorporation of polemical passages into a text that has also - and perhaps primarily other functions than polemical confrontation is not rare. In addition to Suerbaum's analysis of Berthold of Regensburg, Southcombe, Suerbaum and Thompson provide an example of John Milton's Lycidas (1638) where lyrical pastoralism bursts into violent exhortation against the corrupt clerics of his own days. According to them, the containment of polemics within particular social, discursive or generic conventions is one of the features that cut across pre-modern polemics. ${ }^{64}$ My case-study of Ulrich von Pottenstein supports this conclusion.

Potentially, Ulrich's translation expanded Zwicker's audience. In practice, however, that was hardly the case. Ulrich's huge treatise never became popular, and with its eleven preserved manuscripts it stayed far behind the readership of the Wiener Schule's more successful works. In addition, some of the manuscripts refer to a monastic audience, ${ }^{65}$ and religious houses also furnished the main readership of Zwicker's original work. With circa 50 extant manuscripts, the latter was far more popular than Ulrich's translation, which in theory could have reached more readers.

There is, however, a certain emphasis on the anti-Waldensian sections among the preserved copies of Ulrich's catechetical encyclopedia. Seven out of eleven manuscripts include at least one whole translated chapter from Cum dormirent homines. Considering that the translation covers fewer than 30 folios within a work of 1200 folios, most of them in the Credo part, the number is not insignificant. In addition, a scribe and a later commentator of the Austrian National Library Cod. 3050 showed particular interest in Waldensians, adding Latin rubrics and marginalia to the index and some anti-Waldensian chapters. ${ }^{66}$ Such metatextual elements are otherwise rare in this manuscript. The evidence is indecisive, but implies that if any part of the encyclopedia attracted attention, it was the translation of the Cum dormirent homines. Had Ulrich von Pottenstein not buried the translation in his gargantuan work, it could have been much more popular and influential.

\section{Conclusions}

Genre borders are always arbitrary, and especially so in compilatory works such as Ulrich von Pottenstein's catechetic treatise. A combination of different sources, which Ulrich translated very loyally, created variation in style and tone in his work. Polemical refutation of heresy found its place among didactic, pastoral and legal passages, and in a thematically structured reference book one register changes into another, sometimes abruptly. Polemical style is not exclusive to the translations of Petrus Zwicker's anti-Waldensian Cum dormirent

64 Southcombe et al., Introduction, 10-11.

65 Wolf, Hof - Universität - Laien, 190-194. On the manuscript tradition, see n. 4 above.

66 ÖNB Cod. 3050, fols. 8v, 9r, 103v, 276v, 277r, 277v, 346vb; see also Välimäki, Awakener of Sleeping Men, 221-222. 
homines: passages that Ulrich most likely wrote himself also contain denigrating language. When describing sthe sleeping men<, Ulrich's translation is, in fact, more accusatory towards the negligent clergymen than Zwicker's original.

Detecting polemics in pastoral and didactic texts is tedious, especially so because much of the late medieval devotional literature is edited only partially, if at all. Changes in style can be unexpected, and polemical sections do not necessarily manifest themselves in indices and rubrics. In this aspect Ulrich's catechetic encyclopedia is actually quite accessible: without Ulrich's own register with its keyword keczer guiding to the anti-heretical sections, his translation of Zwicker's polemic might well have gone unnoticed. Nevertheless, wading through the manuscript leaves is worth the trouble: there seems to be a polemical element or current in late medieval pastoral literature, which has so far not been fully recognised. This dark side of pastoral care is a promising area of research, as we proceed to write a revised history of polemical literature, style and genre.

\section{Acknowledgements}

The research for this article has been funded by the Academy of Finland. Project Profiling Premodern Authors, project number 293024. 


\section{References}

Manuscripts and archival sources

Seitenstetten, Stift Seitenstetten, Cod. 213

SFB 226 Würzburg/Eichstätt. Teilprojekt 5: Ulrich von Pottenstein, Ketzerstellen: Dekalog.

Unpublished transcription from Kalocsa Föszékesegyházi Könyvtár, Ms. 629.

St. Florian, Stift St. Florian, XI 234

St. Paul im Lavanttal, Stift St. Paul, Cod. 77/4

Vienna, Österreichische Nationalbibliothek (ÖNB)

Cod. 3050

Cod. 5393

Vienna, Österreichische Staatsarchiv (ÖStA), Haus-, Hof- und Staatsarchiv (HHStA)

Allgemeine Urkundenreihe 1408 II 17

Würzburg Universitätsbibliothek (UB)

M. ch. f. 51

Zwettl, Stiftsbibliothek,

Cod. 185

Published sources and literature

Assmann, Jan, Moses der Ägypter. Entzifferung einer Gedächtnisspur (seventh edition), (Frankfurt am Main, 2011).

Baptist-Hlawatsch, Gabriele, Das Katechetische Werk Ulrichs von Pottenstein. Sprachliche und rezeptionsgeschichtliche Untersuchungen (Tübingen, 1980).

Baptist-Hlawatsch, Gabriele, Einführung, in: Gabriele Baptist-Hlawatsch (ed.), Ulrich von Pottenstein, Dekalog-Auslegung: Das erste Gebot. Text und Quellen (Tübingen, 1995) 1*-64*.

Biller, Peter, Aspects of the Waldenses in the Fourteenth Century, Including an Edition of their Correspondence. Unpublished PhD Thesis (University of Oxford, 1974).

Biller, Peter, The Anti-Waldensian Treatise Cum Dormirent Homines of 1395 and its Author, in: The Waldenses, 1170-1530: Between a Religious Order and a Church (Aldershot, 2001) 237-269.

Bodemann-Kornhaas, Ulrike, Die Cyrillusfabeln und ihre deutsche Übersetzung durch Ulrich von Pottenstein. Untersuchungen und Editionsprobe (München, 1988).

Doblinger, Max, Die Herren von Walsee. Ein Beitrag zur österreichischen Adelsgeschichte, Archiv für österreichische Geschichte 95 (1906) 335-578.

Döllinger, Johann Joseph Ignaz von, Beiträge zur Sektengeschichte des Mittelalters. Zweiter Theil. Dokumente vornehmlich zur Geschichte der Valdesier und Katharer (München, 1890).

Ernst, Peter, Ulrich von Pottenstein. Leben und Werk nach dem Stand der neueren Forschung, Unsere Heimat 58 (1987) 203-213.

Gonnet, Jean and Molnár, Amedeo, Les Vaudois au Moyen Âge (Torino, 1974).

Grundmann, Herbert, Der Typus des Ketzers in mittelalterlicher Anschauung, in: Ausgewählte Aufsätze, Schriften der Monumenta Germaniae Historica 1 (Stuttgart, 1976) 313-327.

Haupt, Herman, Waldenserthum und Inquisition im südöstlichen Deutschland seit der Mitte des 14. Jahrhunderts, Deutsche Zeitschrift für Geschichtswissenschaft 3 (1890) 337-411.

Hayer, Gerold, Paternoster-Auslegung. Nach der Handschrift a X 13 des Erzstiftes St. Peter zu Salzburg kritisch herausgegeben und eingeleitet. I. und III. Teil. Unpublished PhD Thesis (University of Salzburg, 1972). 
Hohmann, Thomas, ১Die recht gelerten maister«. Bemerkungen zur Übersetzungsliteratur der Wiener Schule des Spätmittelalters, in: Fritz Peter Knapp and Herbert Zeman (eds.), Die Österreichische Literatur. Ihr Profil von den Anfängen im Mittelalter bis ins 18. Jahrhundert (1050-1750), (Graz, 1986) 349-365.

Kahlos, Maijastina, Nocturnal Rituals as an Othering Device: The Long Life of Fears and Labels in Ancient Polemic and Legislation, in: Raimo Hakola, Nina Nikki and Ulla Tervahauta (eds), Others and the Construction of Early Christian Identities (Helsinki, 2013) 313344 .

Lackner, Christian, Hof und Herrschaft. Rat, Kanzlei und Regierung der österreichischen Herzoge (1365-1406), (Wien, 2002).

Lasson, Emilie, Superstitions médiévales. Une analyse d'après l'exégèse du premier commandement d'Ulrich de Pottenstein (Paris, 2010).

Menhardt, Hermann, Funde zu Ulrich von Pottenstein (etwa 1360-1420), in: Festschrift für Wolfgang Stammler zu seinem 65. Geburtstag dargebracht von Freunden und Schülern (Berlin, 1953) 146-171.

Modestin, Georg, Ketzer in der Stadt. Der Prozess gegen die Strassburger Waldenser von 1400, Monumenta Germaniae Historica, Studien und Texte 41 (Hannover, 2007).

Modestin, Georg, Peter Zwicker (gest. nach dem 7. Juni 1404), in: Friedrich Andreae (ed.), Schlesische Lebensbilder 10 (Breslau, 2010) 25-34.

Modestin, Georg, The Anti-Waldensian Treatise Cum Dormirent Homines: Historical Context, Polemical Strategy, and Manuscript Tradition, in: Michael Van Dussen and Pavel Soukup (eds), Religious Controversy in Europe, 1378-1536 (Turnhout, 2013) 211-229.

Nickson, M., The >Pseudo-Reinerius« Treatise, the Final Stage of a Thirteenth Century Work on Heresy from the Diocese of Passau, Archives d'histoire doctrinale et littéraire du moyen âge 42 (1967) 255-314.

Österreichische Chronik von den 95 Herrschaften, ed. Joseph Seemüller, MGH Deutsche Chroniken 6 (Hannover, 1909).

Patschovsky, Alexander, Der Passauer Anonymus: Ein Sammelwerk über Ketzer, Juden, Antichrist aus der Mitte des 13. Jahrhunderts, MGH, Schriften 22 (Stuttgart, 1968).

Sackville, Lucy J., Heresy and Heretics in the Thirteenth Century: The Textual Representations (York, 2011).

Schmidtke, Dietrich, Ulrich von Pottenstein, in: Lexikon des Mittelalters VIII (München, 1997) 1200-1201.

Segl, Peter, Die Waldenser in Österreich um 1400. Lehren, Organisationsform, Verbreitung und Bekämpfung, in: Albert de Lange and Kathrin Utz Tremp (eds.), Friedrich Reiser und die "waldensisch-hussitische Internationale" im 15. Jahrhundert. Akten der Tagung ÖtisheimSchönenberg, 2. bis 4. Oktober 2003 (Heidelberg, 2006) 161-188.

Segl, Peter, Ketzer in Österreich (Paderborn, 1984).

Southcombe, George, Suerbaum, Almut and Thompson, Benjamin, Introduction, in: Almut Suerbaum, George Southcombe and Benjamin Thompson (eds.), Polemic: Language as Violence in Medieval and Early Modern Discourse (Farnham, 2015) 1-14.

Steckel, Sita, Une querelle des théologiens? The Concept of « Polemic » in the Historiography of the Secular-Mendicant Controversy, in: Bénédicte Sère (ed.), Polémologies Médiévales, forthcoming.

Suerbaum, Almut, Language of Violence: Language as Violence in Vernacular Sermons, in: Almut Suerbaum, George Southcombe and Benjamin Thompson (eds.), Polemic: Language as Violence in Medieval and Early Modern Discourse (Farnham, 2015) 125-148. 
Ulrich von Pottenstein, Dekalog-Auslegung: Das erste Gebot. Text und Quellen, ed. Gabriele Baptist-Hlawatsch, Texte und Textgeschichte 43 (Tübingen, 1995).

Ulrich von Pottenstein, Paternoster-Auslegung. Nach der Handschrift a X 13 des Erzstiftes St. Peter zu Salzburg kritisch herausgegeben und eingeleitet. II. Teil, ed. Gerold Hayer. Unpublished PhD Thesis (University of Salzburg, 1972).

Utz Tremp, Kathrin, Von der Häresie zur Hexerei. »Wirkliche« und imaginäre Sekten im Spätmittelalter (Hannover, 2008).

Valentin Preuenhueber, Annales Styrenses: Sammt dessen übrigen historisch- und genealogischen Schrifften, zur Erläuterung der österreich. steyermärckischen und steyerischen Geschichten, (Nürnberg, 1740).

Välimäki, Reima, The Awakener of Sleeping Men. Inquisitor Petrus Zwicker, the Waldenses, and the Retheologisation of Heresy in Late Medieval Germany. Unpublished PhD Thesis (University of Turku, 2016).

Williams-Krapp, Werner. Konturen einer religiösen Bildungsoffensive. Zur literarischen Laienpastoration im 15. und frühen 16. Jahrhundert, in: Andreas Meyer (ed.), Kirchlicher und religiöser Alltag im Spätmittelalter. Akten der internationalen Tagung in Weingarten, 4.-7. Oktober 2007 (Ostfildern, 2010) 77-88.

Williams-Krapp, Werner, Observanzbewegungen, monastische Spiritualität und geistliche Literatur im 15. Jahrhundert, Internationales Archiv für Sozialgeschichte der Literatur 20 (1995) 1-15.

Wolf, Klaus, Hof - Universität - Laien. Literatur- und sprachgeschichtliche Untersuchungen zum deutschen Schrifttum der Wiener Schule des Spätmittelalters, (Wiesbaden 2006).

Wolf, Klaus, Propter utilitatem populi: Durch des nucz willen seines volkes. Die sstaatstragender Rezeption der 'Summa de vitiis` des Guilelmus Peraldus in der spätmittelalterlichen Wiener Schule, in: Christoph Flüeler and Martin Rohde (eds), Laster im Mittelalter (Berlin, 2009) 187-199.

Zwicker, Petrus, [Cum dormirent homines.] [Pseudo]-Petri de Pilichdorf contra Haeresin Waldensium Tractatus, in: Lucae tvdensis episcopi, Scriptores aliqvot svccedanei contra sectam waldensivm, ed. Jakob Gretser, in: Maxima bibliotheca veterum patrum et antiquorum scriptorum ecclesiasticorum, vol XXV, ed. Marguerin de la Bigne (Lvgdvni, 1677) 277F-299G. 


\title{
Magistra magistrorum: Hildegard of Bingen as a Polemicist against False Teaching
}

\author{
Andra Alexiu*
}

The present paper explores the role that gendered concepts of teaching, preaching, and prophecy played in the polemical writings of Hildegard of Bingen. As this type of discourse was an integral part of the prophetic persona, the analysis focuses on how it shaped itself in order to remain within the boundaries of orthodoxy, which forbade women to preach. Employing a prophetic persona was one of the few means through which women were able to produce texts that could tackle problems which affected the Church in its entirety, such as heresy. The concept of teaching, more precisely the sharp distinction between good and false teaching are essential for understanding not only how Hildegard viewed her mission, but also how this mission was supposed to be carried out within the limits accepted by the Latin Church. By inspecting the manner in which bad and false teaching were thematised in order to serve as a polemical instrument, one can glean how polemics were embedded in texts. A careful analysis of the source material thus needs to start from a theoretical discussion of sermon and preaching - as the texts analyzed here have traditionally been linked with both of these concepts. Scholars usually tend to overlook the ultimately performative function of preaching, yet this is what made the concept relevant in a social context.

Keywords: prophecy; teaching; preaching; audiences; public communication; heresy; gender

In an extensive letter dated 1165, John of Salisbury (1120-1180) informs the exiled Archbishop of Canterbury, Thomas Becket (1118-1170), in passing, about the activity of some unnamed German prophetesses (prophetissas Teutonicas), presumably Hildegard of Bingen (1098-1179) and Elisabeth of Schönau (1129-1164). Predictably, a fervent supporter of Pope Alexander III such as John would not have depicted the allies of the schismatic Frederic Barbarossa in the most favourable light, and the nameless sibyls are held responsible for sending the dissenting Teutons into a frenzy through the power of their prophecies. ${ }^{1}$ Only one year later, in a letter addressed to Master Gerard Pucelle (c. 1117-1184), the same John

\footnotetext{
* Correspondence details: Andra Alexiu, Historical Seminar, University of Münster (WWU), Domplatz 6, 48143 Münster, Germany. Email: andra.alexiu@uni-muenster.de.

1 John of Salisbury, Letter 152, ed. Millor and Brooke, 54-55.
} 
speaks highly of Hildegard, referring in lavish terms to the visions and the prophesies of most famous and blessed Hildegard « who, according to him, was cherished by Pope Eugenius swith an intimate bond of affection. $\iota^{2}$ While there is little contextual evidence to explain this apparently sudden shift of tone ${ }^{3}$ and attitude, both letters seem to agree that she acted as a prophetess.

A more powerful portrayal of this role is found in a letter, dated around 1170 when the visionary nun fell ill with a sickness. Lamenting the apparent imminence of her death, ${ }^{4}$ her secretary and close collaborator Volmar (d. 1173) wrote:

Who then will give answers to all who seek to understand their condition? Who will provide fresh interpretations of the Scriptures? Who then will utter songs never heard before and give voice to that unheard language? Who will deliver new and unheard-of sermons on feast days? Who then will give revelations about the spirits of the departed? Who will offer revelations of things past, present, and future? Who will expound the nature of creation in all its diversity? ${ }^{5}$

This short passage illustrates how her prophetic inspiration was perceived as a source of scriptural interpretation, sermons, and answers to those who sought to better understand their social or existential condition. It is therefore no surprise that, despite the diversity of her work, Hildegard's oeuvre finds its unifying thread in the prophetic mission that is not only claimed, but also attributed to her. In order to gain a clearer perception of what this mission entails, a passage from French theologian Alan of Lille's (c.1128-c.1202) Summa de arte praedicatoria is revelatory: 'For preaching is that type of instruction which is offered to many, in public, and for their edification; teaching is however given to one or to many to aid to their knowledge; prophecy is the admonition which is given for the revelations of those yet to come. $\kappa^{6}$ As such, for thinkers of the late twelfth century, prophecy represented a

2 John of Salisbury, Letter 185, ed. Millor and Brooke, 224-225: si non aliud occurit quod nostratibus desit, saltem uisiones et oracula beatae illius et celeberrimae Hildegardis apud uos sunt; quae michi ex eo commendata est et uenerabilis, quod eam dominus Eugenius speciali caritatis affectu familiarius amplectebatur. Explorate etiam diligentius et rescribite an ei sit de fine huius scismatis aliquid reuelatum.

3 On John of Salisbury's generally ambivalent attitude, see Grellard and Lachaud, Companion to John of Salisbury, 8-12.

4 In the end, Hildegard not only recovered, but also outlived Volmar by six years. On her collaboration with Volmar, see Mews, Male-Female Spiritual Partnership.

5 Hildegard of Bingen, Epistula 195, ed. van Acker, 443-444: Vbi tunc responsum de uniuersis casibus suis querentium? Vbi tunc noua interpretatio Scripturarum? Vbi tunc uox inaudite melodie et uox inaudite lingue? Vbi tunc noui et inauditi sermones in festis sanctorum? Vbi tunc ostensio de animabus defunctorum? Vbi tunc manifestatio preteritorum, presentium et futurorum? Vbi tunc expositio naturarum diuersarum creaturarum, diuina dante gratia cum suauissimis et cum humillimis moribus, et cum materna affectione circa omnes affluentibus uisceribus quam in te nouimus?

6 Alan of Lille, Summa de arte praedicatoria in PL 210, 112A: Ea enim differentia est inter praedicationem, et doctrinam, et prophetiam, et concionationem, Praedicatio enim est illa instructio quae pluribus fit, et in manifesto, et ad morum instructionem; doctrina vero est quae vel uni, vel pluribus fit, ad scientiae eruditionem; prophetia, est admonitio quae fit per revelationem futurorum; concionatio est civilis admonitio, quae fit ad reipublicae confirmationem. 
special form of imparting Christian doctrine, one that was quite distinct from preaching. The main goal of this article is to offer preliminary observations on how Hildegard, building on the contemporary understanding of prophecy as a distinct category of teaching, was able to articulate a polemical discourse which would then function in the public space. ${ }^{7}$

Starting from this distinction, it is quite interesting to rediscuss Hildegard's commitment to the fight against heresy, which had, in theory, provided women with an opportunity to engage in public debates. Therefore, by focusing on Hildegard's anti-heretical writings, an important aspect - which has not captured the attention of scholars so far - should be discussed, namely the role played by the concept of teaching, with its implicit gender undertones, in the construction and use of a polemical discourse.

Hildegard's involvement in the quest against the Cathars is not a new theme in itself. ${ }^{8}$ Recently, Beverly Mayne Kienzle tried to demonstrate that Hildegard's dedication to the anti-heretical activity is actually much stronger and broader than previous research used to interpret, permeating especially her Homilies on the Gospel..$^{9}$ On the other hand, many historians, such as Uwe Brunn, have brought under scrutiny the concept of Catharism, arguing that Hildegard's so-called anti-Cathar texts ${ }^{10}$ need to be seen as a product of the struggle between various clerical camps which opposed each other during the schism caused by Frederic Barabarossa's refusal to recognize the validity of Alexander III's election. ${ }^{11}$ Whether one chooses to accept Brunn's hypothesis or not, schism and heresy did share a lot in common on a discursive level and, as the texts cited at the beginning of the article illustrate, tackling them constituted one of the main parts of Hildegard's writings. Against this backdrop, one would legitimately ponder how a woman was able to produce such an influential polemical discourse ${ }^{12}$ one that was directly intertwined with all the major issues of the moment. From the fragment of Volmar's letter cited above, one can already grasp that Hildegard was, first and foremost, a dispenser of what he considered to be the good knowledge. Hence, it is quite interesting to see how the visionary nun set a clear boundary between good and bad teaching when she wrote her most powerful sermons, the ones addressed to the clergymen in Cologne, Mainz, and Trier.

7 In recent years, with an eye towards sociological theories, medievalists have been interested in refining the understanding of the concept of public, see, for example, Melve, Inventing the Public Sphere or Connnell, Popular opinion. For the limits of using Habermas's theory for the Middle Ages, see the Introduction to this volume by Sita Steckel.

8 Amongst the first publications interested in this topic, see Müller, Hl. Hildegard im Kampf; Manselli, Amicizia spirituale.

9 Kienzle, Hildegard of Bingen and Her Gospel Homilies, 245-288.

10 Apart from Brunn's book, there are other authors who seem to adhere not only to the idea that Catharism did not exist as a unitary religious phenomenon, but also that the very existence of the Cathars is questionable. On this topic, see Biller, Goodbye to Catharism.

11 Brunn, Des contestataires aux « Cathares », 247-262.

12 See especially the influence of Hildegard's sermon, included in her Epistolarium, addressed to the Cologne clergy mirrored in its history of its reception, Embach, Schriften Hildegards von Bingen, 222-228. 
One of the first obstacles this endeavour faces is to assign these polemical texts to a specific genre. Most scholars labelled them sermons ${ }^{13}$ and, furthermore, linked them to a rather exceptional preaching activity. However, as the correlation between written message and the messenger's social agency has not been thoroughly explored so far, it is rather unclear to what extent the category of "preaching " might still be accurate in Hildegard's case. As such, the rhetorical tools used in order to produce the discourse depended not only on gender, but also on the social dimension and its respective performance.

These rather abstract concepts are entangled to a degree which becomes obvious if Hildegard's case is discussed with Alan of Lille's definition in mind. For him, as well as for other monastic writers such as Rupert of Deutz, ${ }^{14}$ this activity was linked with the service at the altar and had a public dimension. Thus, using the twelfth century perception of preaching and admonishing ${ }^{15}$ proves more than useful in developing an understanding of how polemics $^{16}$ might have functioned from a gendered perspective within the orthodox frameworks established at that time. As Hildegard's writings seem to stand on the threshold between strictly defined categories, Alan's all-encompassing concept of teaching allows us to see how Hildegard viewed her mission within the Church: she was a prophetess and her role was to strongly denounce what constituted bad or false teaching, in other words deviance from Christian doctrine. As will be shown, this lay at the core of her admonitio.

In order to better understand how admonition could constitute the ground for a polemical message, one must first scrutinize the differences between categories such as admonition and predication in the words and narratives used when referring to Hildegard's activity as a prophetess or as a magistra magistrorum. This discussion will first be approached from a theoretical perspective, by looking at the main difficulties that scholars seem to be faced with when talking about sermons and preaching, and about their relation to the public debate, both in terms of audience and of (symbolic or concrete) venue. Afterwards, the study will proceed towards a closer inspection of how Hildegard viewed her mission in this context, by focusing on some of the passages in which she discusses the concept of teaching. This will not only shed light on how she perceived the range of her mission, but also on the way she positioned herself accordingly in the heated religious debates of her time by producing a polemical discourse. This, in turn, will help analyze how notions such as bad and false teaching are thematised in order to serve as a polemical tool.

13 A genre that itself raises some theoretical difficulties: Kienzle, Sermon, 143-174.

14 Van Engen, Rupert of Deutz, 317-334: In this regard Rupert adopts an apologetic position arguing for the superiority of the monk-priest and for his entitlement to the tithes with respect to his pastoral duties.

15 The practice of admonition has been the subject of several recent contributions which focused mostly on the Early Middle Ages. Suchan, Mahnen und Regieren; de Jong, Admonitio and Criticism of the Ruler. For the role that admonition played in education, see Steckel, Kulturen des Lehrens, 171-181.

16 Hettema and van der Kooij, Religious Polemics in Context; Iogna-Prat, Order and Exclusion, 120-147; Suerbaum et al., Polemic, 1-14. 


\section{Preaching in the Twelfth Century}

Given the fluidity of the genre, stressed time and again by scholars of sermon studies, defining and analysing the medieval sermon proves to be quite a difficult task.${ }^{17}$ This means that adding new perspectives to the study of preaching contributes to an ongoing refinement of our understanding of what preaching meant for different periods and different religious cultures of the Middle Ages. Compared to the rather rigid perspective on this particular genre provided by Longère, who understood preaching as a public act addressed to society as a whole ${ }^{18}$ for Beverly Mayne Kienzle the idea of audience (and not society) plays a much more significant role, providing an operational definition for the concept in question. ${ }^{19}$ While audiences are, for a modern reader, necessarily linked to what one might call going out publicly, and thus opened to a public debate, medieval thinkers tended to invest certain venues and performances with a public dimension which could restrict certain individuals from the public space either physically - based on gender as well as social criteria - or intellectually - based on the orthodoxy of the expressed ideas - or both.

In Hildegard's times, just like today in many Christian denominations, women's exclusion from the service at the altar - comprised of administering the sacraments as well as edifying the lay audience - was firmly grounded in Paul's epistle 1 Cor. 14: 34-35. Furthermore, the church was perceived (and still is) as the public space par excellence by all its members and efforts were made in order to clearly define the rules which governed this space concerning both the ritual as well as the way in which space imposed a segregation based on the abovementioned criteria.

Thus, in an "orthodox « framework, women could symbolically enter the space of the altar only by donating their handwork. ${ }^{20}$ When he proposed his classification of different forms of teaching, Alan of Lille most certainly had in mind the space of the Church and the sacerdotal office, as he referred to the public edification of the many. Another institutional venue which acted in a similar fashion was the judicial court, where women seem to have been excluded physically both in theory as well as in practice. ${ }^{21}$ Furthermore, a notable example is offered in the Chronicle of William of Puylaurens: in the eighth chapter, William describes a public debate between Dominicans and Waldensians which took place, sometime in the first decade of the thirteenth century, in Pamiers and from which the sister of Bernard-Roger, Count of Foix, was swiftly dismissed with the following words: "Go lady, and work at your distaff! It can be no business of yours to join in a debate such as this. $\aleph^{22}$ Therefore, speaking about "audience» and "performance» brings a significant addition to our understanding of what preaching

17 Muessig, What is Medieval Monastic Preaching; Kienzle, Sermon, 147-155.

18 Longère, Prédication médiévale, 12: «Prêcher c'est faire un discours public fondé sur une Révélation divine, dans le cadre d'une société organisée, visant à la naissance ou au développement de la foi et des connaissances religieuses et, corrélativement, à la conversion ou au progrès spirituel des auditeurs. »

19 Kienzle, Sermon, 151: "The sermon is essentially an oral discourse, spoken in the voice of a preacher, who addresses an audience, to instruct and exhort them, on a topic concerned with faith and morals and based on a sacred text."

20 Griffiths, Medieval Religious Women. For further references on the link between orthodoxy and preaching see the above-mentioned example of Waldensian women preachers, respectively.

21 Davies and Fouracre, Settlement of Disputes, 217

22 William of Puylaurens, Chronicle, 24. 
meant in the Middle Ages - especially if we look at those women who produced written or oral discourses which have recently been associated with public preaching. An inspection of Hildegard of Bingen's writings can provide the necessary ground for understanding the relationship between specific literary genres and their concrete agency in medieval society. Furthermore, it can also shed light on how polemics functioned when produced by women.

One of the questions that attracted the attention of sermonists over the course of time concerns the problem of authorization and its importance when drawing the borders of orthodoxy. ${ }^{23}$ The theme of women's activity as preachers is closely connected to the question of authorization and the nature of the space in which preaching was being conducted. Indeed, Hildegard has been acknowledged for a long time as one of the most outstanding women of the Middle Ages, ${ }^{24}$ precisely because she was well-known and sought out for her writings and spoken performances. But did Hildegard perceive her mission in a similar manner to that of a preacher? Being not only a magistra of a nun's convent but also the founder of two monasteries, she enjoyed greater liberty than regular nuns, especially when compared to those that were organized according to the ideal of the Hirsau reform. ${ }^{25}$ As the community from $\mathrm{Ru}-$ pertsberg was directly dependent on the abbatial authority of Disibodenberg, Hildegard needed to travel frequently in order to establish a network of friends and protectors who could secure the autonomy of her foundations. ${ }^{26}$ Both her Epistolarium and the hagiography written by Theodoric of Echternach ${ }^{27}$ state that she travelled extensively ${ }^{28}$ during her lifetime for different reasons - the most prominent regarding the dissemination of a new understanding of God's message.$^{29}$ It has, however, become obvious that one needs to take precautions when linking Hildegardian texts with public preaching. After Franz Felten briefly expressed his scepticism towards the notion that Hildegard's journeys to various monasteries and chapter houses constituted preaching tours, ${ }^{30}$ Beverly Kienzle recently conceded that:

There are no grounds for concluding that Hildegard engaged in the sort of public tours that Bernard of Clairvaux and other male ecclesiastical leaders undertook. [...] Hildegard could have spoken in the venue of a chapter house, whether a cathedral chapter, as in Cologne, where her friend Philip of Heisenberg was the Dean before becoming archbishop [sic], or the accustomed venue of a monastic chapter, where informal preaching took place on a daily basis. ${ }^{31}$

23 Kienzle, Preaching as Touchstone.

24 On the still somewhat limited bibliography on this subject, see Kienzle, Sermon, 153, 288-289; Mooney, Authority and Inspiration.

25 For a description of the female communities influenced by the Hirsau reform, see Küsters, Formen und Modelle; Hotchin, Female Religious Life.

26 For Hildegard's connection to three of the most important Dioceses in the Holy Roman Empire, see Holbach, Hildegard von Bingen und die kirchlichen Metropolen.

27 Theodoric of Echternach, Vita Sanctae Hildegardis, ed. Klaes, 54-55; Hildegard of Bingen, Epistulae 77-77R, ed. van Acker, 166-175 (esp. 174); ibid, Epistulae 149-149R, 332-337; ibid, Epistula 138, 311-312; ibid, Epistula 159, 355.

28 Kienzle, Hildegard of Bingen and Her Gospel Homilies, 51-52.

29 Theodoric of Echternach, Vita Sanctae Hildegardis, ed. Klaes, 165-175.

30 Felten, Hildegard von Bingen.

31 Kienzle, Hildegard of Bingen and Public Voices, 319. Cf. this conclusion with her earlier postulation on this topic, Kienzle, Defending the Lord's Vineyard; Kienzle, Crisis and Charismatic Authority, where she argues for a more active role for Hildegard as a public preacher. 
If we are to look at the changes that took place in the second half of the twelfth century, the fact that Hildegard could act against the reform movement taking place at the time is quite significant. For nuns, this movement brought, in theory at least, increasingly less room for manoeuvre. The second Lateran Council (1139) not only introduced the idea of a clear separation between the monastic communities of men and of women, which generally translated into a strict enclosure for women, ${ }^{32}$ but also brought the exclusion of monastic actors from preaching. ${ }^{33}$ While this ideal may have never been put entirely into practice, women seem to have been engaged - at least according to the continuously expanding body of literature on polemics - in various types of public activities that their contemporaries perceived as preaching. As such, in addition to the restrictions imposed by canon law, the end of the twelfth century saw women preachers being targeted by anti-heretical writings; the Waldensian women preachers, for instance, were described as deceitful, and therefore compared to Queen Jezebel. ${ }^{34}$ It is noteworthy that Bernard of Fontcaude (d. c. 1192), who dedicated a whole chapter of his Adversus Waldensium sectam liber to discussing the problem of women preachers, seems to have made a decisive difference between preaching and prophesying, considering the latter appropriate even for women..$^{35}$ Thus the complex religious turmoil urged many writers to operate a clear cut differentiation between categories describing the activity of disseminating the orthodox teaching. This sort of differentiation was never categorically enforced; rather, as its later transfer towards the scholastic disputes reveals, the ambiguous use of these categories created some paradoxes within the official position of the Church, of which various scholastics seemed to be nervously aware. ${ }^{36}$

How did Hildegard perceive her role in the polemical texts that she had written? What concept lies at the core of these texts? Answering these questions would help us better place Hildegard's polemical activity, when comparing it to that of other famous contemporary authors of anti-heretical texts. Hildegard does not directly address the problem of heresy, which can intrinsically be a convincing argument that the heretics were not her audience. In more than a few aspects, Hildegard resembles Bernard of Clairvaux (1090-1153), who also approached the problem of heresy over the course of several sermons on the Song of Songs. But compared to Bernard, who used to preach in his own name and could therefore present his own approach when dealing with heresy, ${ }^{37}$ Hildegard was careful to attribute the utterance to God's Grace made manifest.

32 On the enclosure regime in the twelfth century, see Hotchin, Enclosure and Containment, cf. Felten, What Do We Know About the Life of Jutta. There are two major sources that elaborate on the necessity of a strict enclosure for women, dating from around the middle of the twelfth century: Speculum virginum and Aelred of Rievaulx's treaty De institutione inclusarum.

33 Zerfaß, Streit um die Laienpredigt; Bynum, Docere Verbo et Exemplo.

34 Kienzle, The Prostitute-Preacher.

35 Bernard of Fontcaude, Liber adversus Waldensium sectam in PL 204, 827B-828A: Nec dicitur hic, quia praedicavit vel docuit; sed »locuta est de Christo omnibus, qui exspectabant redemptionem Israel. «Non est idem, praedicare et loqui. [...] Cum igitur aliud sit donum prophetiae, aliud sermo doctrinae, secure concesserim, Annam, seu quasdam mulieres prophetasse; nec tamen consequenter dicendum erit, easdem docuisse; alioqui male posuit Apostolus eadem quasi diversa.

36 Cf. Blamires, Women and Preaching, 150.

37 For a detailed analysis of Bernard of Clairvaux's anti-heretical preaching, see Kienzle, Cistercians, Heresy, and Crusade, 78-108. 


\section{Hildegard's Concept of Teaching}

Franz Felten offered a brief but concise description of Hildegard's public persona as that of a "conservative reformist « $^{38}$, which would also best describe the prophetical authority ascribed to her. ${ }^{39}$ These two concepts are essential for understanding how Hildegard's authority functioned as both a prophetess and a reformist. Her texts not only plead for, but also impose and reinforce the necessity of reform, while preserving a perspective of society rooted in the Benedictine tradition. Hildegard, raised as an oblate, ${ }^{40}$ would have been part of this milieu from an early age. This aspect becomes visible when we look closer at both her concept of teaching and her understanding of the role which she envisaged for herself in the process of teaching publicly. Her first visionary work, Sciuias, discusses at length several aspects of teaching in the second book, through the inclusion of three visions that deal with the order of the Church, the sacraments and the Devil's actions against them.$^{41}$ Over the course of these visions, good teaching appears as a means for both the edification and articulation of the female figure of the Ecclesia. Furthermore, it constitutes the attribute of priests who are scarrying the health-giving chrism and announcing the divine law to the people. $\mathbf{~}^{42}$

When talking about omnis ecclesiasticus ordo ${ }^{43}$, the order comprised of all bishops and priests, she discusses teaching in relation to chastity and correct ordination, two themes of major interest for the movement of church reformation. Her definition, which is obviously rooted in the ecclesiastical tradition, alludes clearly to a pastoral understanding which emphasises the model of docere verbo et exemplo by giving similar importance to the act of preaching and to physical and spiritual perfection. Although teaching is defined by Hildegard in a very general manner, without going into the details about what it should contain, she nonetheless points towards the major aspects that need to be taken into consideration by a proper teacher: good intentions (rectam intentionem), work of activity (perfectum opus operationis) and wholeness of chastity (castitas integritatis). What is more, through penitence, the clergy's missteps from the role that the divine office offered to them, namely that of preaching through word and deed (verbo et exemplo), can be corrected..$^{44}$ Basically, the idea at stake here is that priests, through their office, ought to address a broader audience in a performative manner, in other words by offering a living example of their teaching.

38 Felten, Noui esse uolunt.

39 On the process of Hildegard's authorization, see Van Engen, Letters and the Public Persona; Van Engen, Authorship, Authority, and Authorization. Another type of analysis of the concept of authority, deeply influenced by a Pseudo-Dionysian tradition, can be found in Meier, Autorschaft im 12. Jahrhundert.

40 On the practice of oblation, see de Jong, In Samuel's Image. Hildegard's oblation and education are discussed in Flanagan, Hildegard of Bingen, 22-31.

41 Hildegard of Bingen, Scivias II. 5-7, eds. Führkötter and Carlevaris, 172-325.

42 Hildegard of Bingen, Scivias II. 5, eds. Führkötter and Carlevaris, 177: [...] ipsorum saluberrima pigmenta gestantes fideliter plateas et uillas et ciuitates atque alia loca regionum et terrarum pertranseunt, et populo diuinam legem annuntiant. English translation in Hildegard of Bingen, Scivias, trans. Hart and Bishop, 203.

43 Hildegard of Bingen, Scivias II. 4, eds. Führkötter and Carlevaris, 166-167.

44 Hildegard of Bingen, Scivias II. 5, eds. Führkötter and Carlevaris, 178-179. 
How does Hildegard see her own mission fit within this quite rigid model of orthodoxy? Like many major visionary works, some of her writings reinstate the motif of a world turned upside down, ${ }^{45}$ in which, against the backdrop of a lack of zeal from the ecclesiastical office holders, the divinely established order is threatened by the devil. ${ }^{46}$

A letter requested by the provost of the cathedral of St. Peter in Trier, which Hildegard had visited in order to warn and advise the local office holders in the Trier diocese, offers a hint of how she actually understood the prophetical call as underpinning, and thus legitimizing, her reformist activity. It is not surprising that Hildegard addressed such an essential discussion on the prophet's role within society to one of her most important audiences, comprised of both ecclesiastic and monastic figures, as her direct links to Trier are supported by genealogical evidence (since Andrew, one of Hildegard's nephews, served as Archbishop of Trier) as well by the manuscript transmission - both these connections are fairly well reflected in her Epistolarium and in the Vita.

In her response, Hildegard denounces the apathy of the masters and superiors of the Church towards their pastoral duties and then engages in a long rendition of Church History, in a manner that is typical for the works oriented towards the history of salvation. Amongst other aspects, she touches upon the role reserved for prophets in this global outlook:

For He established the prophets first to be the head, the wise to be the eyes, the teachers to be the mouth, just as all things came into being by the Word of God. And, then, because the rest of the body, that is, the faithful, will do good works, as I have said, God will place their head in His lap, that is to say, He will reveal the meaning of prophecy to them. ${ }^{47}$

We are here presented with a threefold division: prophets, wise ones, and teachers. One can catch a glimpse of how this scheme of disseminating divine knowledge was meant to function by looking at the correspondence of the magistra with her last collaborator, Guibert of Gembloux (1124-1213). In a second letter written to Hildegard, he presents the reader with outstanding details about the way in which her teaching might have functioned in the public space par excellence - the Church. After receiving Hildegard's letter of reply, Guibert underwent a solitary reading, of a private and mystical sort, having previously gone through a ritual of self-cleansing through prayer. He then started translating it into the vernacular, in order to read it publicly in the Church to a mixed audience the following day and even to offer a copy of the letter to all those who were present at that time. ${ }^{48}$

45 This is quite a classical theme in the rhetoric of Gregorian Reform. For a broader contextualization, see Bynum, Docere Verbo et Exemplo, 22-58.

46 A theme which is discussed at length in Hildegard of Bingen, Scivias II. 7, eds. Führkötter and Carlevaris, 273-325.

47 Hildegard of Bingen, Epistula 223R, ed. van Acker, 494-495: Ipse namque prophetas primum constituit uelut caput, sapientes uelut oculos, doctores uelut os, sicut etiam per uerbum Dei omnia facta sunt. Et quia deinde reliqua membra, scilicet fideles, bona operabuntur, ut dictum est, Deus in sinum eorum caput ponet, id est intellectui ipsorum prophetiam aperiet. Translated in Hildegard of Bingen, Letter 223R, ed. Baird and Ehrman, 21.

48 Guibert of Gembloux, Epistula 18, ed. Derolez, 225-234. 
Hildegard, assuming a prophetic identity which made her a vessel of revealed teaching, did not attempt to substitute herself for the de facto teachers, whose association with the Ecclesia's mouth is not fortuitous, and to whom speaking is attributed, in other words, the duty of teaching the laity. They were to guide the faithful through mediated teaching and through their own example. On the other hand, however, direct access to revealed knowledge places prophets and consequently Hildegard in a vastly superior position to any other human instances. In other words, it offered her the role of judge and mediator, one who could write and admonish, but without public instruction in a public space, therefore without the right to preach. As such, her understanding of the concept of teaching must be traced back to the vocabulary that is specific to Benedictine culture, which alludes to religious teaching and pastoral activity.$^{49}$ It thus becomes clear how religious women, carefully understanding and observing the boundaries of their cultural environment, could assume the social role of informal instructors outside their communities, achieving this without being perceived as undermining the acceptable confines of orthodoxy.

As has already been discussed in the opening section, Alan of Lille distinguished three types of teaching, namely preaching (or praedicatio), doctrina, and prophetia. According to him, only preaching - which is opened to a broader audience - is clearly linked with the idea of "public", as doctrina and prophetia seem to lack this dimension. If we cumulate this statement with Hildegard's scheme, described above, it becomes clear that preaching was an activity which could only have been performed by those who were designated through a formal office to perform it and who were instructed by the upper layer of spiritual experts in order to instruct those placed on a lower spiritual stratum - a scheme which strongly resembles the pseudo-Dionysian ideal of transmitting the idea of God. For Hildegard's particular case, as later for that of Bernard of Fontcaude, this seems important as most sources written by or about her are built on the image of the unlearned feminine figure..$^{50}$ Yet, when she presents herself as a prophetess, she acts as a disseminator of divine knowledge.

\section{On False Teaching}

Focusing now on "false teaching " offers a good vantage point in distinguishing between various stages of the anti-heretical discourse in Hildegard's writings. Having established that she perceived her position as guardian of "good teaching ", Hildegard seems to implicitly assume the role of informal teacher of the clerics, or, following a pattern frequently used in the world of schools to designate the masters of equally great disciples, ${ }^{51}$ to shape herself as a magistra magistrorum. From this position, she deals with the problem of false teaching. As an instructor with direct access to divine knowledge or Truth, it was Hildegard's mission to admonish the teachers of the many. Although exhortation was to be performed only within the framework of officium caritatis, that is, in the name of true Christian charity, its main function was

49 Ferzoco and Muessig, Medieval Monastic Education; Steckel, Kulturen des Lehrens, 116-124.

50 Meier, Eriugena im Nonnenkloster.

51 For an analysis of the relationship between master and students, as reflected in the vocabulary that is employed, see Steckel, Doctor Doctorum. 
to correct error. While some errors could be corrected by penance, others proved to be not only persistent but also dangerous for the entire ecclesiastical edifice, precisely because they resisted correctio. Under these circumstances, the intention of correcting motivated the use of invective to denounce the wrongdoings in a forceful manner, thus enabling the polemical potential of the discourse.

Analyzing the historical circumstances under which Hildegard's first major book of visions was created (Sciuias - around 1141-1152), leaves no doubt why distinguishing between good and bad teaching lies at the core of Hildegard's activity. Heresy shook many parts of the Latin West and manifested itself in various forms; echoes of this complex spiritual phenomenon could not pass without leaving traces in Hildegard's early writings, as it offered a good legitimation for the informal office of teacher of teachers.

While one might trace an early allusion to heresy as far back as her letter to St. Bernard of Clairvaux, ${ }^{52}$ a longer meditation on this subject can be found in Sciuias, where it is included in the broader discussion about the devil's work in society. ${ }^{33}$ She starts by addressing the heretics sharply as uiscera eiusdem incongruentis bestie (गthe very bowels of that unnatural beast`). ${ }^{54}$ Then, assuming God's voice, she continues as follows:

You, you evil deceivers, who labour to subvert the Catholic faith. You are wavering and soft, and thus cannot avoid the poisonous arrows of human corruption, which you employ as you wish against the Law. And after you pour out your lust in the poisonous seed of fornication, you pretend to pray and falsely assume an air of sanctity, which is more unworthy in My eyes than the stinky mire. [...] you are worse than earlier people, because you perceive the true law of God but stubbornly abandon it. ${ }^{55}$

The work that contained this vision was being completed during a period when several heretical groups were assumed to be active in various dioceses of the Rhinelands. It is therefore no surprise that the Hildegardian anti-heretical meditation presents countless similarities in language to other texts which dealt with this problem directly. One key source in this regard is provided by the Premonstratensian prior Evervin of Steinfeld (d.1152), who sent a letter to Saint Bernard in 1143, urging him to tackle the problem of heresy once more, ${ }^{56}$ as old and new threats were menacing the diocese of Cologne. While the old heretics are, as Malcom Lambert has suggested, presented as rigorists or promoters of a radical form of ascetic life who would

52 See the letter sent to Bernard of Clairvaux, around 1147, in which she alludes to multa schismata sunt in hominibus (there are many schisms among people - my translation) cf. Hildegard of Bingen, Epistula 1, ed. van Acker, 4.

53 Hildegard of Bingen, Scivias II. 7, eds. Führkötter and Carlevaris, 307-325.

54 Hildegard of Bingen, Epistula 169R, ed. van Acker, 381.

55 Hildegard of Bingen, Scivias II. 7, eds. Führkötter and Carlevaris, 322: [...] uos pessimi deceptores estis qui fidem catholicam subuertere laboratis. Vos instabiles et molles ad deuitandum uenenosas sagittas humanae pollutionis estis, quas secundum uoluntatem uestram contra legem exercetis. Vnde postquam uenenoso semine fornicationis libidinem uestram euacuatis, tunc ficte oratis et sanctitatem uobis fallaciter imponitis, quod oculis meis foetente luto indignius est. [...] peiores priori populo exsistentes, quoniam ueram legem Dei cernentes, eam pertinaciter abicitis.

56 See Bernard's sermon against Henry the Monk in Wakefield and Evans, Heresies of the High Middle Ages, $122-124$. 
refuse to obey the ordained clerics on the grounds of their impurity, ${ }^{57}$ the new ones (>certain other heretics in our land differing completely «) carry a number of resemblances to the Cathars (although Evervin does not label them as such). ${ }^{58}$ Beyond the perfunctory description of the various types of heretics, Evervin's letter provides three important elements. First and foremost, the Premonstratensian prior associates all of them with the heretics that sshall appear toward the end of the world ${ }^{59}$ secondly, their audience is extremely large and encompasses both lay as well as spiritual people, and thirdly, they are accompanied by women despite pretending to be chaste. ${ }^{60}$ In the sermon that Saint Bernard apparently wrote at the suggestion of Evervin as a part of the commentary on the Song of Songs, ${ }^{61}$ the former insisted at length on the point concerning the scandalous association of women to these heretical groups. ${ }^{62}$

By quickly reviewing the three sources, it becomes clear that Hildegard makes use of all major categories of anti-heretical preaching topoi, namely that of demonization, pollution, threat to social order, and apocalypticism, in a similar manner to her two contemporaries. ${ }^{63}$ What is more, in what could be considered the first stage of her anti-heretical discourse, Hildegard seems to be faithful to the standard imprecatory discourse, employed with much skill and with impressive imagination.

\section{Hildegard as a Polemicist}

While Sciuias cannot be specifically linked to a certain heretical movement, later in her life Hildegard appears to have been actively involved in a campaign directed against the snew heretics s that Evervin of Steinfeld's letter references, namely those who have been subsequently labelled Cathars. ${ }^{64}$ The one who used the term for the first time to name this heretical group, targeting it in one of his treatises, is Eckbert of Schönau (d. 1184). Active in his youth as a canon in Bonn, he disputed with Cathars from Bonn, Cologne, and later from Mainz. ${ }^{65}$ This direct experience would have lain at the basis of his most famous Sermons against the

57 Lambert, Medieval Heresy, 64. For the English translation of the letter see Wakefield and Evans, Heresies of the High Middle Ages, 127-132. Evervin calls them rapostolics of Satan<, mocking their apostolic aspiration and the label of sElectr.

58 Wakefield and Evans, Heresies of the High Middle Ages, 130.

59 Namely those announcing the coming of the Antichrist: ras though already their prince was about to be loosed and the day of the Lord were at hand in Wakefield and Evans, Heresies of the High Middle Ages, 128, cf. II Thessalonians 2.9-2.10.

60 Wakefield and Evans, Heresies of the High Middle Ages, 132: »These apostolics of Satan have among them women vowed to continence (so they say): widows, virgins, and their wives, some among the Elect, some among the believers."

61 Kienzle, Tending the Lord's Vineyard; Kienzle, Cistercians, Heresy, and Crusade, 78-108.

62 Bernard of Clairvaux, Sermo 65, eds. Leclercq et al. 175: Alioquin temere tibi usurpas illorum dispensationem, quorum sanctitatem non habes. Cum femina semper esse, et non cognoscere feminam, nonne plus est quam mortuum suscitare? [...] Quotidie latus tuum ad latus juvenculae est in mensa; lectus tuus ad lectum eius in camera, oculi tui ad illius oculos in colloquio, manus tuae ad manus ipsius in opere; et continens vis putari?

63 This taxonomy is proposed and discussed in Kienzle, Preaching as Touchstone, 21.

64 Manselli, Ecberto di Schönau; Moore, War on Heresy, 167-173.

65 On Eckbert of Schönau's activity see, Brunn, Des contestataires aux « Cathares », 207-220. 
Cathars. Corroborating different accounts that refer to the period between 1143-1163, R. I. Moore notes that "the triangle between Liege, Cologne and Trier not only introduces us, in two sources, to the word Cathar, but provides for the first time a full and detailed account of those to whom it was applied. ${ }^{66}$ Decades ago, Raoul Manselli tried to integrate Hildegard's writing into a concerted action, led by Eckbert of Schönau, against the Cathars. ${ }^{67}$ Indeed his sister, Elisabeth, following the divine command, took up the pen to write against the Cathars. She also tried to convince her older visionary fellow and mentor to join the fight. ${ }^{68}$ However, Hildegard gave no formal answer to Elisabeth's letter of petition that was passed down to us. ${ }^{69}$

It is in this context that Hildegard produced a series of visions, sometimes labelled sermons by scholars, in which she reveals a more innovative polemical discourse, engaging with the theme of false teaching. ${ }^{70}$ At least two of her letters attest her approach to this central polemical aspect of her work. One was written at the request of a monastic community, probably from Mainz. ${ }^{71}$ The second addresses the clergy in Cologne. According to the letter pairing in her Epistolarium, the former letter comprised an older work, as the monks showed interest in Hildegard's anti-Cathar writings. ${ }^{72}$ The latter of the two is her most popular and probably best-known work. It was produced at the request of Dean Philip of Cologne. From his letter of petitio, we infer that this text is based on a previous spoken communication, of which we know too little to label it more specifically. ${ }^{73}$ It is worth noting that Philip does not offer a single reference or clue to the existence of Cathars or of any other heretical sect.

What does a closer look at this second phase of Hildegard's polemical activity reveal? Intriguingly enough, Hildegard precisely dates the treatise sent to the presumed monastic community in Mainz - July $1163 .{ }^{74}$ This predates the trial against the Cathars in Cologne by one month; the heretics, namely four men and a young woman according to the chronicles of the city, were defeated in a debate, and later burnt at the stake..$^{75}$ Although this writing briefly mentions the problem of ineffective clerical teaching, Hildegard insists on the poisonous

66 Moore, Origins of European Dissent, 175-176.

67 Manselli, Amicizia spirituale.

68 Elisabeth of Schönau, Liber visionum III, ed. Roth, 70-75.

69 It is quite intriguing, however, that the "MSS of Redaction D of Elisabeth's visionary collection « also contains a small treatise written by Hildegard and directed against the Cathars; Clark, Elisabeth of Schönau, 157, n. 73.

70 It is fairly problematic to judge to what degree the echoes of this new heretical outbreak could have either appeared in her writings many years later, or actually inspired other works which did not directly deal with the problem. See Kienzle's interpretations versus those of Brunn.

71 Hildegard of Bingen, Epistula 169R, ed. van Acker, 378-382.

72 Hildegard of Bingen, Epistula 15R, ed. van Acker, 34-47.

73 Hildegard of Bingen, Epistula 15, ed. van Acker, 33: Rogamus etiam, ut ea que uiua uoce nobis prius dixistis, litteris quoque commendetis et nobis transmittatis, quia, dum carnalibus concupiscentiis dediti sumus, spiritalia, que nec frequenter uidemus nec audimus, facile per negligentiam obliuioni tradimus.

74 Hildegard of Bingen, Epistula 169R, ed. van Acker, 378: Mense Iulio presentis anni, qui est millesimus centesimus sexagesimus tertius dominice incarnationis, aspiciens a longe uidi in umbra uere uisionis sub altare quod est ante oculos Dei, et etiam uidi sub thronum Dei.

75 Chronica regia Coloniensis in MGH SRG 18, ed. Waitz, $114 \mathrm{cf}$. with the account offered by Dietrich of Deutz in MGH SS 13, ed. Waitz, 286-287. 
teaching of the heretics, though in a somewhat general and ambiguous manner. While some of her contemporaries already labelled them as Cathars or at least as heretics, she does not use these or any similar terms, instead naming her opponents by using older topoi such as sadduceis similes (like the Sadducees), similes illis qui Baal Deum nominant (similar to those who call Baal God), sulphurei montes (sulphurous mountains), similes scorpionibus (like scorpions), and peiores Iudeis (worse than the Jews). ${ }^{76}$ However, she seems to hint towards the central theological aspect in relation to which the Cathars are deviating from the orthodox line, as she alludes to the idea of a false teaching which denies God as first principle. ${ }^{77}$ Some of the invectives used previously in Sciuias are reprised here and a few new ones are added, especially the accusation of false prophecy:

And just as the prophets preceded the Lord and prophesied in the way of salvation, demonstrating that He was filled with all the virtues of justice, so too do these precede the beast, embracing the filth and wickedness of all evils, going the way of the errant. For these prophets were inspired and taught by the finger of God, just as the devil fills these people with blasphemy, wickedness, and the falseness of all evil. ${ }^{78}$

Going back to the letter addressed to the clergy of Cologne, Hildegard employs arguments of a somewhat different nature. She develops the idea that priests who do not preach against heresy cannot be called actual teachers. The treatise begins by clearly differentiating between the priests who are good teachers and the deviant ones that stray from the precepts of good teaching. This time, her admonitory voice is full of wrath and she does not hesitate to gradually stress all the sins and the faults that the deviant priests are guilty of. The text culminates with them being denounced as impeding the act of teaching on which the entire edifice of Ecclesia rests, by opposing their pastoral vocation: syou do not properly teach your subordinates, nor indeed do you even allow them to seek instruction from you. ${ }^{79}$ She reiterates, time and time again, that most of the priests had ceased to represent a moral compass for the believers, contributing to the increasing popularity of false teachers.

While the identity of these false teachers is never disclosed, Hildegard extensively decries their falsely pious behaviour which helps them gain popularity amongst maioribus secularibus principibus ('great secular princes`) ${ }^{80}$ and women. If we compare the language used in this second letter to that in Sciuias, which seems to have been influenced by Bernard, the charges of sexual promiscuity of the heretics are missing from the text of this sermon. ${ }^{81}$

76 Hildegard of Bingen, Epistula 169R, ed. van Acker, 380-381.

77 Hildegard of Bingen, Epistula 169R, ed. van Acker, 381: Hi sunt qui prima principia negant, scilicet quod Deus omnia creauit et ea germinando et crescendo procedere iussit.

78 Hildegard of Bingen, Epistula 169R, ed. van Acker, 381: Et sunt etiam uiscera eiusdem incongruentis bestie que excipit et exspuit pessimam immunditiam, et precedunt eam, amplectendo spurcitiam ac nequitiam omnium malorum, per uiam errantium, sicut prophete Dominum prophetauerunt in uia salutis, eum ostendentes cum omnibus uirtutibus iustitie; quos digitus Dei inspirauit et docuit, sicut et diabolus blasphemia et nequitia et mendacio omnium malorum istos imbuendo replet.

79 Hildegard of Bingen, Epistula 15R, ed. van Acker, 37: subditos uestros non imbuitis, nec eos doctrinam a uobis querere permittitis.

80 Hildegard of Bingen, Epistula 15R, ed. van Acker, 40.

81 Hildegard of Bingen, Epistula 15R, ed. van Acker, 41-42: Ipsi autem in inceptione seductionis erroris sui mulieribus dicent: Non licet uos nobiscum esse, sed quoniam rectos doctores non habetis, nobis obedite et quecumque uobis dicimus et precipimus, facite et salue eritis. 
Furthermore, the image of chastity seems to gain a new understanding, with magical undertones: the devil has given the evildoers perfect chastity and they are now able to resist temptation..$^{82}$ The stress upon the physical perfection of the heretics, inspired by the devil, is meant to highlight the flaws of the clerical teachers even more. It becomes clearer that correct teaching is at stake now, as the seducers of the layman could oppose the corrupt clergy precisely through their physical purity, which should have been an external sign of a good priest. The reference to the persecution of righteous teachers, unleashed by the heretics, makes more sense when considering that this logic of thought seems to be behind it. The very head and stability of the Church are directly menaced by these persecutors. ${ }^{83}$

\section{Conclusions}

It is safe to conclude that Hildegard's polemical activity shows a profound influence and similarity to that of other monastic authors of her time. Nonetheless, in her case, the entire discussion revolves around the notion of prophet or prophetess - understood as the highest magister or magistra in Christian society - upon whom the responsibility of safeguarding and restoring divine doctrine falls. Hildegard repeatedly stresses that prophets should restore the good teaching by admonishing those who fail to teach, as this is an integral part of the duty for which they were ordained. This can be traced even in her famous letter addressed to the pastors of the church, in a passage that contains her meditation on the function attributed by the divine knowledge to each of the three major magisterii of the Church. ${ }^{84}$ Moreover, given her position, it is quite interesting how most texts referring to Hildegard's activity neither use predicare nor give a clear picture of Hildegard speaking publicly, meaning in front of a broader audience comprised of laypeople. Thanks to her last collaborator, Guibert of Gembloux, we have a testimony of an instance in which her visions were publicly read, although not by Hildegard herself. Despite being placed on an elevated plane owing to her prophetic knowledge, her discourse remains confined to the strict frames of the orthodox line of the twelfth century, which did not look favourably upon women preachers.

The texts discussed previously clearly illustrate that the concept of teaching is a tool, which Hildegard handled with care and skill. The implicit question is who were her targets? At a first glance, the obvious answer to this question would seem to be that the heretics are the intended receivers of Hildegard's invectio, especially when the idea of false teaching is employed. Yet, upon a closer inspection, it becomes clear that the reason why Hildegard did not directly address heretics is that her intended audience was meant to be restricted to those clerics and monks who were duty-bound to teach through word and example. Thus, aimed

82 Hildegard of Bingen, Epistula 15R, ed. van Acker, 40-41: Nam diabolus per aerios spiritus hec operatur, qui propter praua opera hominum in sufflatu uenti et aeris ita innumerabiles circa quosdam discurrunt sicut musce et culices, qui in ardore caloris homines pre multitudine sua infestant. Ipse enim homines istos hoc modo infundit, quod castitatem eis non aufert et quod eos castos esse permittit, cum castitatem habere uoluerint; unde mulieres non amant, sed eas fugiunt.

83 Hildegard of Bingen, Epistula 15R, ed. van Acker, 41: Nam alii homines qui eo tempore in fide catholica errant, istos timebunt et seruili seruitio eis ministrabunt, et quantum poterunt eos imitabuntur. Cumque isti cursum erroris sui hoc modo compleuerint, doctores et sapientes, qui tunc in catholica fide persistunt, undique persequentes expellent, sed tamen non omnes, quoniam aliqui illorum fortissimi milites in iustitia Dei sunt.

84 See the passage from Hildegard's letter addressed to the clergy of Trier quoted above, Epistula 223R. 
at the bad and unchaste clergymen who were blamed for the success of false teachers, her harsh admonitory tone echoes the prophetical increpatio. ${ }^{85}$ This vision was quite likely meant to be performed as a sermon in front of a broader audience by a good priest, thus drawing a clear line between the good and the bad clergy. One can easily imagine that a public reading by Philip of such an extreme form of admonition might have contributed to the release of its full offensive potential, transforming it into an invectio. This scenario becomes even more plausible when placed in the context of the Schism within the Latin Church. ${ }^{86}$

Although Hildegard has never been acknowledged as a magistra magistrorum in the same way in which Bruno the Carthusian (1030-1101), for instance, was recognized by his pupils, the visionary nun of Bingen nonetheless played this role informally for many of her correspondents, as a more careful analysis of her letter collection plainly reveals. Through prophetical admonition, Hildegard was always careful to present herself as a guardian and informal disseminator of sacred teaching, despite her womanly condition. From this elevated plane of the prophetical voice, she could produce an extremely powerful written discourse. Her writings do not offer many innovations in terms of reform or anti-heretical topoi. What they do offer is her rather unique and allusive manner of adapting them. This style envelops her entire discourse, which is always carefully placed within the established boundaries of orthodoxy. This skilful polemical discourse proved to be appealing not only to her contemporaries, but also to future generations of polemicists. Its high degree of ambiguity, combined with the powerful invective, made it easy for it to be removed from its original context and adapted to suit other contexts - as would happen starting with 1230, when Gebeno of Eberbach (fl. 1220) wrote his Speculum futurorum temporum as a "Hildegardian breviary ${ }^{87}{ }^{87}$

\section{Acknowledgements}

The present study was supported by the Volkswagen Foundation within the framework of the Dilthey Fellowship led by Sita Steckel entitled »Diversitas religionum. Thirteenth-century foundations of European discourses of religious diversity". It is an extended version of a paper presented at the International Medieval Congress in Leeds 2016. The author is indebted to Sita Steckel and Julie Hotchin for reading and offering insightful comments on earlier drafts of this article.

85 On various stages of admonition, see de Jong, Admonitio and Criticism, 320-323.

86 Brunn, Des contestataires aux « Cathares », 247-262, cf. Moore, War on Heresy, 165-171.

87 Kerby-Fulton, Reformist Apocalypticism, 28-56. 


\section{References}

Aelred of Rivaulx, De Institutione Inclusarum: ed. Charles Hugh Talbot CCCM 1 (Turnhout, 1971).

Alan of Lille, Summa de arte praedicatoria, PL 210, col. 0109-0198A.

Bernard of Clairvaux, S. Bernardi Opera Vol. II. Sermones super cantica canticorum 36-86, eds. Jean Leclercq, Charles Hugh Talbot and Henri M. Rochais (Rome, 1958).

Bernard of Fontcaude, Liber adversus Waldensium sectam, PL 204, col. 0793-0840D.

Biller, Peter, Goodbye to Catharism?, in: Antonio C. Sennis (ed.), Cathars in Question (York, 2016) 274-312.

Blamires, Alcuin, Women and Preaching in Medieval Orthodoxy, Heresy, and Saints' Lives, Viator 26 (1995) 135-152.

Brunn, Uwe, Des contestataires aux " Cathares »: discours de réforme et propagande antihérétique dans les pays du Rhin et de la Meuse avant l'Inquisition (Paris, 2006).

Bynum, Caroline Walker, Docere Verbo et Exemplo: An Aspect of Twelfth-Century Spirituality (Missoula, Montana, 1979).

Chronica Regia Coloniensis, ed. Georg Waitz, MGH SRG 18 (Hannover, 1880).

Clark, Anne L., Elisabeth of Schönau: A Twelfth-Century Visionary (Philadelphia, 1992).

Connell, Charles W., Popular Opinion in the Middle Ages: Channeling Public Ideas and Attitudes (Berlin, 2016).

Davies, Wendy, and Paul Fouracre (eds.), The Settlement of Disputes in Early Medieval Europe (Cambridge, 1992).

Elisabeth of Schönau, Die Visionen der Hl. Elisabeth und die Schriften der Aebte Ekbert und Emecho von Schönau. Ein Beitrag zur Mystik und Kirchengeschichte. Nach den OriginalHandschriften. Mit historischem Abrisse des Lebens der Hl. Elisabeth, der Aebte Ekbert und Emecho von Schönau, ed. Ferdinand W. E. Roth (Brünn, 1884).

Embach, Michael, Die Schriften Hildegards von Bingen: Studien Zu Ihrer Überlieferung Und Rezeption Im Mittelalter Und in Der Frühen Neuzeit. Erudiri Sapientia 4 (Berlin, 2003).

Engen, John H. Van, Rupert of Deutz (Berkley,1983).

Engen, John Van, Letters and the Public Persona of Hildegard of Bingen, in: Alfred Haverkamp (ed.), Hildegard von Bingen in ihrem historischen Umfeld. Internationaler wissenschaftlicher Kongreß zum 90o-jährigen Jubiläum 13-19. Sept. 1998 in Bingen (Mainz, 2000) 375-418.

Engen, John Van, Authorship, Authority, and Authorization: The Cases of Abbot Bernard of Clairvaux and Abbess Hildegard of Bingen, in: Shari Boodts, Johan Leemans, and Brigitte Meijins (eds.), Shaping Authority: How Did a Person Become an Authority in Antiquity, the Middle Ages and the Renaissance? (Turnhout, 2016) 325-362.

Felten, Franz J., Noui esse uolunt ... deserentes bene contritam uiam ... Hildegard von Bingen und Reformbewegungen im religiösen Leben ihrer Zeit, in: Rainer Berndt (ed.), `Im Angesicht Gottes suche der Mensch sich selbstr: Hildegard von Bingen (1098-1179) (Berlin, 2001) 27-86.

Felten, Franz J., Hildegard von Bingen 1198-1998 - oder: Was bringen Jubiläen für die Wissenschaft?, Deutsches Archiv für Erforschung des Mittelalters 59/1 (2003) 165-194.

Felten, Franz J., What Do We Know About the Life of Jutta and Hildegard at Disibodenberg and Rupertsberg?, in: Beverly Mayne Kienzle, Debra L. Stoudt and George Ferzoco (eds.), A Companion to Hildegard of Bingen. Translated from German by John Zaleski (Boston, 2014) 15-38. 
Ferzoco, George and Muessig, Carolyn (eds.), Medieval Monastic Education (London, 2000). Flanagan, Sabina, Hildegard of Bingen, 1098-1179: A Visionary Life (London, 1989).

Grellard, Christophe and Frédérique, Lachaud (eds.), A Companion to John of Salisbury (Leiden, 2014).

Griffiths, Fiona J., 'Like the Sister of Aaron<. Medieval Religious Women as Makers and Donors of Liturgical Textiles, in: Gert Melville and Anne Müller (eds.), Female »Vita Religiosa" between Late Antiquity and the High Middle Ages: Structures, Developments and Spatial Contexts, Vita Regularis 47 (Zürich, 2011).

Guibert of Gembloux, Epistolae Gviberti Gemblacensis Epistolae quae in codice B. R. Brux. 55275534 inueniuntur. Pars I Epistolae I-XXIV, ed. Albert Derolez, CCCM 66 (Tvrnholti, 1988).

Hettema, Theo L. and Kooij, Arie van der (eds.), Religious Polemics in Context: Papers Presented to the Second International Conference of the Leiden Institute for the Study of Religions (Lisor) Held at Leiden, 27-28 April, 2000 (Assen, 2004).

Hildegard of Bingen, Scivias, ed. Adelgundis Führkötter and Angela Carlevaris, CCCM 43-43A (Tvrnholti, 1978).

Hildegard of Bingen, Scivias, trans. Columba Hart and Jane Bishop (New York, 1990).

Hildegard of Bingen, Epistolarivm, Pars prima, I-XC, ed. Lieven van Acker, CCCM 91 (Turnhout, 1991).

Hildegard of Bingen, Epistolarivm. Pars secvunda, XCI-CCLr, ed. Lieven van Acker, CCCM 91A (Turnhout, 1993).

Hildegard of Bingen, The Letters of Hildegard of Bingen, Vol. 1, trans. Joseph L. Baird and Radd K. Ehrman (New York, 1994).

Hildegard of Bingen, The Letters of Hildegard of Bingen, Vol. 2, trans. Joseph L. Baird and Radd K. Ehrman (New York, 1998).

Hildegard of Bingen, Epistolarivm. Pars tertia CCLI-CCCXC, eds. Lieven Van Acker and Monika Klaes-Hachmöller, CCCM 91B (Turnhout, 2001).

Hildegard of Bingen, The Letters of Hildegard of Bingen, Vol. 3, trans. Joseph L. Baird and Radd K. Ehrman (New York, 2004).

Hildegard of Bingen, Hildegard of Bingen's Unknown Language, ed. and trans. Sarah Lynn Higley (New York, 2007).

Holbach, Rudolf, Hildegard von Bingen und die kirchlichen Metropolen Mainz, Köln und Trier, in: Alfred Haverkamp (ed.), Hildegard von Bingen in ihrem historischen Umfeld. Internationaler wissenschaftlicher Kongreß zum 9oojährigen Jubiläum, 13-19 September 1998, Bingen am Rhein (Mainz, 2000) 71-115.

Hotchin, Julie, Enclosure and Containment: Jutta and Hildegard at the Abbey of St. Disibod, Magistra: A Journal of Women Spirituality in History 2/2 (1996) 103-123.

Hotchin, Julie, Female Religious Life and the Cura Monialium in Hirsau Monasticism, 1080 to 1150, in: Constant Mews (ed.), Listen Daughter! The Speculum Virginum and the Formation of Religious Women in the Middle Ages (New York, 2001) 59-83.

Iogna-Prat, Dominique, Order and Exclusion: Cluny and Christendom Face Heresy, Judaism, and Islam (1000-1150) (Ithaca, 2002).

John of Salisbury, The Letters of John of Salisbury 2: The Later Letters (1163-1180), ed. William J. Millor and Christopher N. L. Brooke, (Oxford, 1979).

Jong, Mayke de, In Samuel's Image: Child Oblation in the Early Medieval West (Leiden, 1996). 
Jong, Mayke de, Admonitio and Criticism of the Ruler at the Court of Louis the Pious, in: François Bougard, Régine Le Jan and Rosamond McKitterick (eds.), La culture du haut Moyen Âge: une question d'élites? [Actes de la rencontre de Cambridge des 6, 7 et 8 septembre 2007] (Turnhout, 2009) 315-338.

Kerby-Fulton, Kathryn, Reformist Apocalypticism and Piers Plowman (Cambridge, 2007).

Kienzle, Beverly M., Tending the Lord's Vineyard: Cistercians, Rhetoric and Heresy, 11431229. Part I: Bernhard of Clairvaux, the 1143 Sermons and the 1145 Preaching Mission, Heresis 25 (1995) 29-61.

Kienzle, Beverly M., Defending the Lord's Vineyard: Hildegard of Bingen's Preaching against the Cathars, Medieval monastic preaching (Leiden, 1998) 163-181.

Kienzle, Beverly M., The Prostitute-Preacher. Patterns of Polemic against Medieval Waldensian Women Preachers, in: Beverly Mayne Kienzle and Pamela J. Walker (eds.), Women Preachers and Prophets through Two Millennia of Christianity (Berkeley, 1998) 99-113.

Kienzle, Beverly M., Preaching as Touchstone of Orthodoxy and Dissidence in the Middle Ages, Medieval Sermon Studies 43 (1999) 19-54.

Kienzle, Beverly M. (ed.), The Sermon (Turnhout, 2000).

Kienzle, Beverly M., Cistercians, Heresy, and Crusade in Occitania, 1145-1229: Preaching in the Lord's Vineyard (Rochester, New York, 2001).

Kienzle, Beverly M., Hildegard of Bingen and Her Gospel Homilies: Speaking New Mysteries (Turnhout, 2009).

Kienzle, Beverly M., Crisis and Charismatic Authority in Hildegard of Bingen's Preaching against the Cathars, in: Katherine L. Jansen and Miri Rubin (eds.), Charisma and Religious Authority: Jewish, Christian, and Muslim Preaching (Turnhout, 2010) 73-91.

Kienzle, Beverly M., Hildegard of Bingen and Public Voices of Women in Medieval Society, in: Rainer Berndt and Maura Zatonyi (eds.), Unversehrt und unverletzt. Hildegards von Bingen Menschenbild und Kirchenverständnis heute (Münster, 2015) 309-322.

Küsters, Urban, Formen und Modelle religiöser Frauengemeinschaften im Umkreis der Hirsauer Reform des 11. und 12. Jahrhunderts, in: Klaus Schreiner (ed.), Hirsau, St. Peter und Paul, 1091-1991. Geschichte, Lebens- und Verfassungsformen eines Reformklosters 2 (Stuttgart, 1991) 195-220.

Lambert, Malcolm D., Medieval Heresy: Popular Movements from the Gregorian Reform to the Reformation (Wiley, 2002).

Longère, Jean, La prédication médiévale (Paris, 1983).

Manselli, Raoul, Amicizia spirituale ed azione pastorale nella Germania del secolo XII: Ildegarde di Bingen, Elisabetta ed Ecberto di Schönau contro l'eresia catara, in: Raoul Manselli, Studi sulle eresie del secolo XII (second edition) (Roma, 1975) 211-220.

Manselli, Raoul, Ecberto di Schönau e l'eresia catara in Germania alla meta del secolo XII, in: Raoul Manselli, Studi sulle eresie del secolo XII (second edition) (Roma, 1975) 191-210.

Meier, Christel, Eriugena im Nonnenkloster? Überlegungen zum Verhältnis von Prophetentum und Werkgestalt in den figmenta prophetica Hildegards von Bingen, Frühmittelalterliche Studien 19 (1985) 466-497.

Meier, Christel, Autorschaft Im 12. Jahrhundert. Persönliche Identität Und Rollenkonstrukt, in: Peter von Moos (ed.), Unverwechselbarkeit. Persönliche Identität und Identifikation in der vormodernen Gesellschaft (Köln, 2004) 207-266.

Melve, Leidulf, Inventing the Public Sphere: The Public Debate During the Investiture Contest (c. 1030-1122). Brill's Studies in Intellectual History 154. (Leiden, 2007). 
Mews, Constant J., Male-Female Spiritual Partnership in the Twelfth Century: The Witness of Aberlard and Heloise, Volmar and Hildegard, in: Rainer Berndt and Maura Zatonyi (eds.), Unversehrt und unverletzt. Hildegards von Bingen Menschenbild und Kirchenverständnis heute (Münster, 2015) 167-183.

Mooney, Catherine. M., Authority and Inspiration in the Vitae and Sermons of Humility of Faenza, in: Carolyn Muessig (ed.), Medieval Monastic Preaching (Leiden, 1998) 123-144.

Moore, Robert I., The Origins of European Dissent (London, 1977).

Moore, Robert I., The War on Heresy: Faith and Power in Medieval Europe (Cambridge, Massachusetts, 2012).

Müller, Gerhard, Die hl. Hildegard im Kampf mit Häresien ihrer Zeit, in: Anton Philipp Brück (ed.), Hildegard von Bingen 1179-1979. Festschrift zum 800. Todestag der Heiligen (Trier, 1998) 171-188.

Muessig, Carolyn, What Is Medieval Monastic Preaching? An Introduction, in: Carolyn Muessig (ed.), Medieval Monastic Preaching (Leiden, 1998) 3-16.

Speculum virginum, ed. Jutta Seyfarth, CCCM 5 (Turnhout, 1990).

Steckel, Sita, Kulturen des Lehrens im Früh- und Hochmittelalter: Autorität, Wissenskonzepte und Netzwerke von Gelehrten (Köln, 2011).

Steckel, Sita, Doctor Doctorum: Changing Concepts of "Teaching" in the Mortuary Roll of Bruno the Carthusian ( $\dagger$ 1101), in: Hartmut Beyer, Gabriela Signori, and Sita Steckel (eds.), Bruno the Carthusian († 1101) and His Mortuary Roll. Studies, Text and Translations (Turnhout, 2014) 83-116.

Suchan, Monika, Mahnen und Regieren. Die Metapher des Hirten im früheren Mittelalter (Berlin, 2015).

Suerbaum, Almut, Southcombe, George and Thompson, Benjamin (eds.), Polemic: Language as Violence in Medieval and Early Modern Discourse (Farnham, Surrey, 2015).

Theodoric of Echternach, Vita Sanctae Hildegardis, ed. Monica Klaes, CCCM 127 (Turnhout, 1993) 19-71.

Wakefield, Walter Leggett and Evans, Austin Patterson (ed.), Heresies of the High Middle Ages: Selected Sources Translated and Annotated. Records of Western Civilization (New York, 1991).

William of Puylaurent, The Chronicle of William of Puylaurens: The Albigensian Crusade and Its Aftermath, edited by William. A. Sibly and Michael D. Sibly (Woodbridge, 2003).

Zerfaß, Rolf, Der Streit um die Laienpredigt: Eine pastoralgeschichtliche Untersuchung zum Verständnis des Predigtamtes und zu seiner Entwicklung im 12. u. 13. Jahrhundert (Freiburg im Breisgau, 1974). 